WORLD

RESOURCES

\title{
THE ECONOMIC BENEFITS OF THE NEW CLIMATE ECONOMY IN RURAL AMERICA
}

\section{EXECUTIVE SUMMARY}

\section{Highlights}

- Rural America can reap significant benefits from investments made in the new climate economy, including measures to advance clean energy systems, remediate abandoned fossil fuel production sites, restore trees to the landscape, and reduce the risk of catastrophic wildfire. Collectively, these actions can create new economic opportunities in rural places while addressing climate change.

- This working paper presents a detailed analysis of the rural economic impact of federal policies that invest in the new climate economy, including information about the geographic and sectoral distribution of those investments.

- The opportunities analyzed here would require US $\$ 55$ billion in annual federal investment nationwide for five years, of which nearly $\$ 15$ billion per year would flow to rural counties. This rural investment could support nearly 260,000 rural jobs that would last for five years (a total of 1.3 million job-years) across the country, if complementary measures were adopted to ensure that a minimum share of funding reaches rural counties. It would also generate $\$ 21.7$ billion per year in overall value added to rural economies, including $\$ 12.9$ billion in rural employee compensation and $\$ 1.6$ billion in local, state, and federal tax revenues.

- Every $\$ 1$ million invested through the new climate economy pathways included in this analysis would generate 17.5 jobs and $\$ 1.5$ million in value added in rural economies.

- Nearly 45 percent of all rural jobs created by these federal investments would accrue to economically disadvantaged rural counties. Federal investments must specifically prioritize equity in distribution to ensure that these benefits reach rural communities in need.

\section{CONTENTS}

Executive Summary

Why Invest in a New Climate Economy

for Rural America?

Key Investment Areas for the Rural

New Climate Economy.

Approach to Estimating Rural Economic Impacts .........10

Rural Economic Benefits of the

New Climate Economy $\ldots 12$

Benefits to Economically Disadvantaged

Communities.

Conclusion 32

Appendices 33

Glossary 92

Abbreviations 92

Endnotes 93

References 94

Working Papers contain preliminary research, analysis, findings, and recommendations. They are circulated to stimulate timely discussion and critical feedback, and to influence ongoing debate on emerging issues. Working papers may eventually be published in another form and their content may be revised.

Suggested Citation: Saha, D., A. Rudee, H. Leslie-Bole and T. Cyrs. 2021. "The Economic Benefits of the New Climate Economy in Rural America." Working Paper. Washington, DC: World Resources Institute. Available online at

https://doi.org/10.46830/wriwp.20.00149. 


\section{Context}

\section{Rural America faces the dual challenges of lagging economic growth and increasingly severe impacts from climate change. These challenges have been highlighted by economic losses from the COVID-19 pandemic, which has exacerbated existing inequalities and infrastructure needs, alongside catastrophic wildfires and severe weather linked to climate change.}

\section{Addressing both challenges at once will require federal investment in building a new climate economy for rural America-one that reduces} greenhouse gas emissions to net zero while creating jobs, uplifting economically disadvantaged communities, and enhancing ecosystem services. Prospective investments in the new climate economy have already garnered broad support from federal policymakers and rural voters alike, but strong federal policy has yet to be enacted. The current push by Congress and the Biden administration to invest in the country's ailing infrastructure and tackle the climate crisis represents the most promising political moment in years to amplify the new climate economy in rural America.

Federal investment in the new climate economy can create jobs, bolster rural economies, and contribute significantly to addressing the climate

crisis. Specific investment opportunities evaluated in this paper include the following:

Developing renewable energy resources

Making homes and industries more energy efficient

Building infrastructure for clean energy transmission, distribution, and storage

Cleaning up abandoned fossil fuel infrastructure

Restoring trees on federal lands through reforestation and restocking degraded forests

Restoring trees on private, state, and local lands through reforestation, restocking, and agroforestry systems

- Reducing the risk of catastrophic wildfire through prescribed burning and biomass removal

While not comprehensive, these opportunities are intended to be representative of key needs for investment in the new climate economy. They are the subject of analysis in this working paper.

\section{About This Working Paper}

This working paper estimates the potential economic benefits in rural America from federal investments that support a new climate economy. Our assessment uses input-output modeling to estimate direct, indirect, and induced job creation in rural counties from specific federal investments across seven pathways, including opportunities in the energy and land sectors (Table ES-1). We also estimate the associated value added to rural economies, including total employee compensation and additional tax revenues to federal, state, and local governments. Based on these results, we analyze the distribution of rural economic benefits across the United States and the proportion of these benefits likely to accrue to economically disadvantaged rural communities, defined as counties identified as distressed and at risk by the Economic Innovation Group's Distressed Communities Index.

We discuss federal policies that could catalyze investments in the new climate economy. The policies presented here could help rebuild U.S. infrastructure in a way that creates jobs, supports economically disadvantaged communities, and addresses climate impacts. While this discussion is targeted at federal lawmakers, state and local policymakers may also find value in these proposals.

Our analysis goes beyond most other published economic analyses of decarbonization policies by segmenting federal investment between rural and urban counties for specific opportunities in both the energy and land sectors, informed by interviews with practitioners and industry experts as well as qualitative case studies. The result is a detailed picture of how federal investments would be distributed across rural counties, including consideration of economically disadvantaged communities. This granularity reflects our understanding that good federal policy requires an intimate knowledge of how investments will translate into economic benefits across sectors and geographies.

This working paper is part of New Climate Economy, a project of the Global Commission on the Economy and Climate, which seeks to enhance our global and national understanding of how climate policy can help unlock economic and social benefits. This paper estimates overall economic benefits only. 

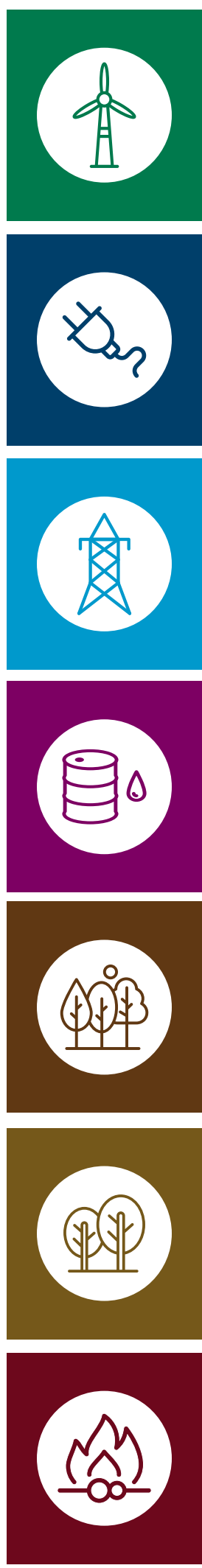

\section{RENEWABLE ENERGY}

$\$ 18.8$ billion annually in federal investment, with $\$ 3.8$ billion going directly to rural counties, would result in the following:

$\cdot 31,600$ direct, indirect, and induced jobs

- $\$ 3.4$ billion in value added to rural economies

- \$1.7 billion in employee compensation

- \$536 million in total tax revenues

\section{ENERGY EFFICIENCY}

$\$ 8.3$ billion annually in federal investment, with $\$ 2.1$ billion going directly to rural counties, would result in the following:

- 29,800 direct, indirect, and induced jobs

- $\$ 2.9$ billion in value added to rural economies

- \$1.6 billion in employee compensation

- \$162 million in total tax revenues

\section{TRANSMISSION, DISTRIBUTION, AND STORAGE}

$\$ 19.6$ billion annually in federal investment, with $\$ 3.4$ billion going directly to rural counties, would result in the following:

- 48,800 direct, indirect, and induced jobs

- $\$ 5.8$ billion in value added to rural economies

- \$3.1 billion in employee compensation

- \$362 million in total tax revenues

\section{ENVIRONMENTAL REMEDIATION OF ABANDONED FOSSIL FUEL INFRASTRUCTURE}

$\$ 2.4$ billion annually in federal investment, with $\$ 1.3$ billion going directly to rural counties, would result in the following:

$\cdot 14,600$ direct, indirect, and induced jobs

- $\$ 2$ billion in value added to rural economies

- \$952 million in employee compensation

- \$164 million in total tax revenues

\section{TREE RESTORATION ON FEDERAL LANDS}

\$445 million annually in federal investment, with 350 million going directly to rural counties, would result in the following:

- 9,200 direct, indirect, and induced jobs

- \$474 million in value added to rural economies

- \$330 million in employee compensation

- \$12 million in total tax revenues

\section{TREE RESTORATION ON NON-FEDERAL LANDS}

$\$ 4.3$ billion annually in federal investment, with $\$ 2.8$ going directly to rural counties, would result in the following:

$\cdot 76,200$ direct, indirect, and induced jobs

- $\$ 3.9$ billion in value added to rural economies

- \$2.7 billion in employee compensation

- \$211 million in total tax revenue

\section{WILDFIRE RISK MANAGEMENT}

$\$ 1.5$ billion annually in federal investment, with $\$ 1.1$ billion going directly to rural counties, would result in the following:

- 49,200 direct, indirect, and induced jobs

- $\$ 3.3$ billion in value added to rural economies

- $\$ 2.5$ billion in employee compensation

- \$182 million in total tax revenues 


\section{The Rural Economic Opportunity}

We evaluate the impact of $\$ 55$ billion per year in federal investment in seven areas of the new climate economy over five years. An estimated $\$ 14.9$ billion of that investment would be directed to rural America. That investment would support nearly 260,000 direct, indirect, and induced jobs in rural counties for at least five years (a total of 1.3 million job-years) and 740,000 jobs in the country as a whole for at least five years (a total of 3.7 million job-years). This equates to 17.5 jobs created per $\$ 1$ million invested in rural counties, compared with 13.5 jobs created per $\$ 1$ million nationally.

This level of investment would also add $\$ 21.7$ billion per year to rural economies for the first five years $-\$ 1.46$ for every dollar invested. This includes $\$ 12.9$ billion in employee compensation and $\$ 1.6$ billion in federal, state, and local tax revenues. Table ES-1 shows the distribution of economic benefits across the seven investment areas in the new climate economy. In absolute terms, rural counties in California, Texas, New Mexico, Missouri, and Wyoming stand to gain the most in terms of job creation each year for the first five years (Figure ES-1).

Of the 260,00o rural jobs created by this investment, over $118,000-$ nearly 45 percent of all rural jobs-would accrue to economically disadvantaged rural counties. These counties would benefit from $\$ 9.8$ billion added to their economies annually, including $\$ 5.9$ billion in total employee compensation and $\$ 685$ million in total taxes.

\section{Figure ES-1 | Geographic Distribution of Rural Job Creation from Federal Investment in Seven Areas of the}

New Climate Economy

Total jobs supported in rural counties of each state (per year for five years).
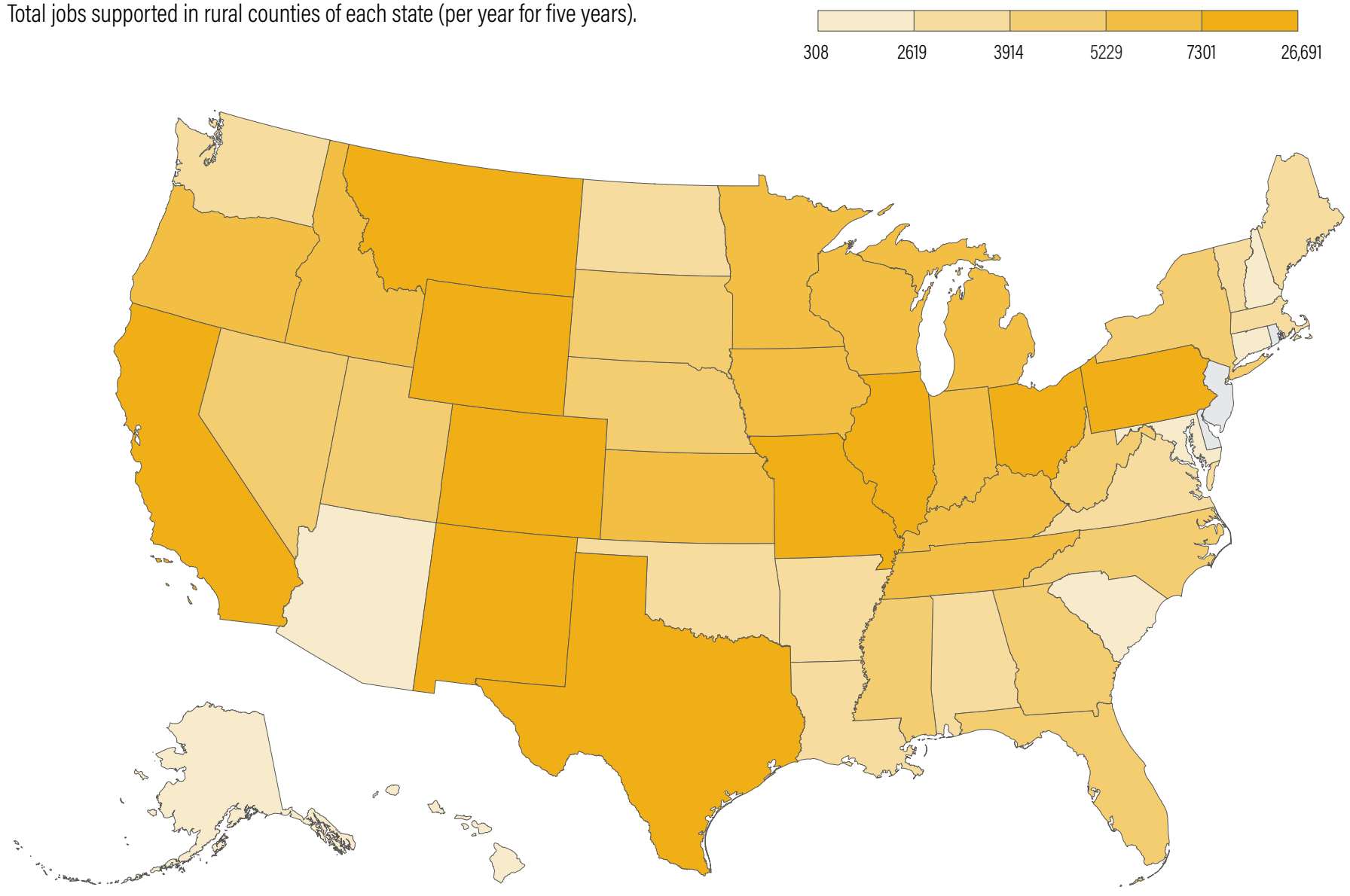

Note: Delaware, the District of Columbia, New Jersey, and Rhode Island do not have any rural counties as defined by the U.S. Department of Agriculture. Source: WRI authors and BW Research. 
The Policy Opportunity

\section{The federal government has an opportunity to enact and expand policies that will drive investments in the new climate economy, creating jobs and bolstering rural economies in the \\ process. Fully activating the opportunities analyzed in}

this paper would require a suite of federal policies, which could support a larger federal plan for rebuilding infrastructure and mitigating climate change. Policy opportunities for the new climate economy are shown in Table ES-2. They include policies that can positively impact the nation as a whole as well as policies specifically tailored to rural areas.

\section{Table ES-2 | Federal Policy Opportunities by Investment Area}

\begin{tabular}{|c|c|}
\hline Renewable Energy & $\begin{array}{l}\text { - } \quad \text { Extend investment tax credits and production tax credits for renewable energy } \\
\text { - } \quad \text { Reauthorize tax incentives for clean energy manufacturing facilities through section } 48 \mathrm{C} \text { of the tax code } \\
\text { Expand grant and loan programs that help rural communities finance renewable energy, including the U.S. Department } \\
\text { of Agriculture (USDA) Rural Energy for America Program (REAP) }\end{array}$ \\
\hline Energy Efficiency & $\begin{array}{l}\text { - Extend tax incentives for efficiency upgrades in homes and residential buildings, including the existing homes tax } \\
\text { credit (tax code sec. 25C) and new homes tax credit (sec. 45L) } \\
\text { Extend tax incentives for efficiency upgrades in new and existing commercial buildings (sec. 179D) } \\
\text { - Boost funding level for block grant programs that channel money directly to state and local agencies for efficiency } \\
\text { upgrades, including the Weatherization Assistance Program, State Energy Program, and Energy Efficiency Conservation } \\
\text { Block Grants program, and create a comparable program for industrial facilities } \\
\text { Expand grant and loan programs targeted at rural communities, including the USDA REAP program, Energy Efficiency } \\
\text { Conservation Loan Program, and Rural Energy Savings Program }\end{array}$ \\
\hline
\end{tabular}
Transmission, Distribution, - . C Create tax credits to incentivize the build out of transmission projects that are regionally significant and can enable and Storage renewable energy integration on the grid and stand-alone energy storage technologies
- $\quad$ Reauthorize tax credits to incentivize domestic clean energy manufacturing facilities (sec. 48C)
- $\quad$ Reauthorize the Department of Energy's Smart Grid Investment Grant program to promote investments in smart grid technologies
- $\quad$ Authorize the Department of Transportation to make transmission infrastructure projects, especially those that emphasize the integration of renewable energy, eligible under the Transportation Infrastructure Finance and Innovation Act loan guarantee program
- $\quad$ Expand loans and loan guarantees through USDA Electric Infrastructure Loan \& Loan Guarantee to help finance transmission and distribution systems in rural areas
- Create a program to provide grants and technical assistance to rural electric cooperatives to deploy energy storage and microgrid technologies

Environmental Remediation of Abandoned Fossil Fuel Infrastructure

Tree Restoration on Federal
Lands

Tree Restoration on Nonfederal Lands
- Increase federal funding to clean up abandoned coal mine sites

- $\quad$ Create a new program for plugging and remediation at orphaned oil and gas well sites
- $\quad$ Remove the funding cap on the Reforestation Trust Fund

- Increase appropriations for programs that fund restoration projects on federal land

- Implement a refundable or transferable tax credit for natural carbon sequestration

- $\quad$ Enhance USDA conservation programs to incentivize natural carbon sequestration and reduce transaction costs for landowners, especially underserved landowners

- $\quad$ Provide additional funding through state and local grants and the State and Private Forestry programs of the U.S. Forest Service (USFS)

Wildfire Risk Mitigation
Increase appropriations for the USFS "hazardous fuels" budget line item and the Department of the Interior Office of Wildland Fire to support fuel load management

- Increase appropriations for the USFS Collaborative Forest Landscape Restoration Program to support and expand existing projects, as well as develop new collaborative forestry projects

- Improve mechanisms for financing wildfire risk management projects such as amending USFS budgetary authority to allow for longer-term contracts and better leverage of private investment 


\section{WHY INVEST IN A NEW CLIMATE ECONOMY} FOR RURAL AMERICA?

Rural America faces dual challenges from flagging economic vitality, exacerbated by the pandemic, and climate change, which is already affecting rural livelihoods (Hales et al. 2014; see Box 1 for a definition of rural America). Efforts to rebuild resilient rural communities would benefit from strategic federal investment that supports both deep decarbonization and the creation of good-paying jobs (Mulligan et al. 2020; Saha and Jaeger 2020). These investments could help usher in a new climate economy for the United States that would achieve economic growth by dealing with the risks associated with climate change (NCE 2018).

There is increasing interest in rebooting struggling rural communities by making strategic investments in the new climate economy. The Biden administration's American Jobs Plan would target 40 percent of clean infrastructure investments in disadvantaged communities, which have experienced disproportionate levels of pollution, chronic disinvestment, and lack of access to economic opportunities. Many rural communities are likely to fall into this category. Legislative proposals to invest in rural areas to combat climate change and generate economic opportunities for underserved communities also abound. For example, the Climate Stewardship Act, introduced in the Senate in April 2021, would invest billions of dollars in U.S. Department of Agriculture (USDA) programs to restore trees and native vegetation on working lands while prioritizing investments and job opportunities for disadvantaged communities. The proposed American Jobs in Energy Manufacturing Act of 2021 would incentivize domestic manufacturing of clean energy technologies, with targeted investments in rural communities that have witnessed a decline in manufacturing and traditional energy jobs.

There is also increasing evidence that rural Americans support the new climate economy. In a national survey, 54 percent of rural voters said that taking action on climate change was "very" or "pretty" important, with policies that reduce pollution from power plants, incentivize the contribution that agriculture can make to mitigation, and strengthen rural communities against extreme weather events receiving high levels of support (Bonnie et al. 2020). Despite their support for climate action, however, rural voters report feeling "isolated" from the climate policy conversation and feel that many climate policies do not allow rural areas to benefit.
Federal policymakers need to ensure that rural voices are included in U.S. climate policy discussions. Not only do rural voters and rural states wield significant influence on the outcomes of national elections, but rural America matters a lot to the fate of U.S. climate policy. Farmers, ranchers, and forest owners manage large segments of American lands that hold enormous opportunities for mitigation. Natural and working lands currently remove about 800 megatons of carbon dioxide $\left(\mathrm{MtCO}_{2}\right)$ per year, or 12 percent of U.S. greenhouse gas (GHG) emissions (EPA 2021), and could remove an additional $540 \mathrm{MtCO}_{2}$ annually-equal to current emissions from U.S. agriculture-if trees were restored to ecologically suitable lands, primarily in rural areas (Mulligan et al. 2020). Rural areas are also crucial for clean energy development: 99 percent of all onshore wind capacity in the country is located in rural areas, as is the majority of utility-scale solar capacity (Seigner et al. 2021). Rural communities are, therefore, essential to building robust, equitable, and durable climate policies that harness the power of rural America to address climate change.

This paper aims to support rural-centric climate policy discussions by evaluating the potential economic benefits of federal investment in rural America, including benefits that accrue specifically to economically disadvantaged rural communities.

Box 1 | What Is Rural America?

For our analysis, we used Rural-Urban Continuum Codes developed by the U.S. Department of Agriculture Economic Research Service to delineate rural areas. This geographic-economic classification scheme distinguishes between two broad types of regions: metropolitan counties (codes 1-3) and non-metropolitan counties (codes 4-9). Rural areas include everything that falls outside a metropolitan area. By this definition, there were 1,976 rural counties, home to approximately 46 million residents, in 2019.

Rural America is not a monolith. It is increasingly home to a diverse population, with 22 percent of rural population being people of color. Rural communities also fall along a wide spectrum of economic profiles, with some deeply impoverished and others doing well economically. On average, though, rural communities lag behind their urban counterparts on most key economic indicators, from poverty rates to labor force participation.

Note: a. Junod et al. 2020. 


\subsection{Declining Economic Opportunities in Rural America}

While urban areas are not uniformly prosperous and rural areas are not uniformly poor, rural America as a whole has been slipping behind its urban counterpart for several decades on metrics including income, educational attainment, access to infrastructure, and job growth (Figure 1). As the United States has urbanized, young people and money have flowed to urban areas, where jobs and educational opportunities tend to exist, while the rural workforce has grown older and less able to access lucrative jobs (Andrews and Reiblich 2020).

Simultaneously, traditionally rural industries like farming, mining, and manufacturing have seen workforces shrink due to mechanization and globalization. Boom-and-bust cycles and the transition toward low-carbon energy production have also left rural fossil fuel workers and communities with shrinking economic opportunities (Kopparam 2020). The closure of coal-fired power plants, for instance, has adversely impacted local communities, many of which are in rural areas, that rely on coal plants for tax revenues and jobs (Morris et al. 2019). Adding to economic pain, rural wages have stagnated for the past 50 years across all skill levels and demographics (Ziliak 2019).

Rural households, and particularly low-income households, have higher energy costs, but many cannot afford to invest in energy efficiency upgrades such as weatherization or efficient appliances that can bring savings. Rural households have a median energy burdenpercentage of income spent on energy-of 4.4 percent, compared with 3.3 percent for urban households, and low-income households face energy burdens almost three times greater than high-income households (Ross et al. 2018). Electric cooperatives, which serve much of rural America, are often strapped for cash, hindering investment in clean energy programs that can benefit their communities.

In addition, climate change has already begun to affect rural livelihoods. Changing precipitation and temperature patterns are impacting crop growth and distribution of

Figure 1 | Rural Areas Lag Urban Areas across Key Economic Indicators

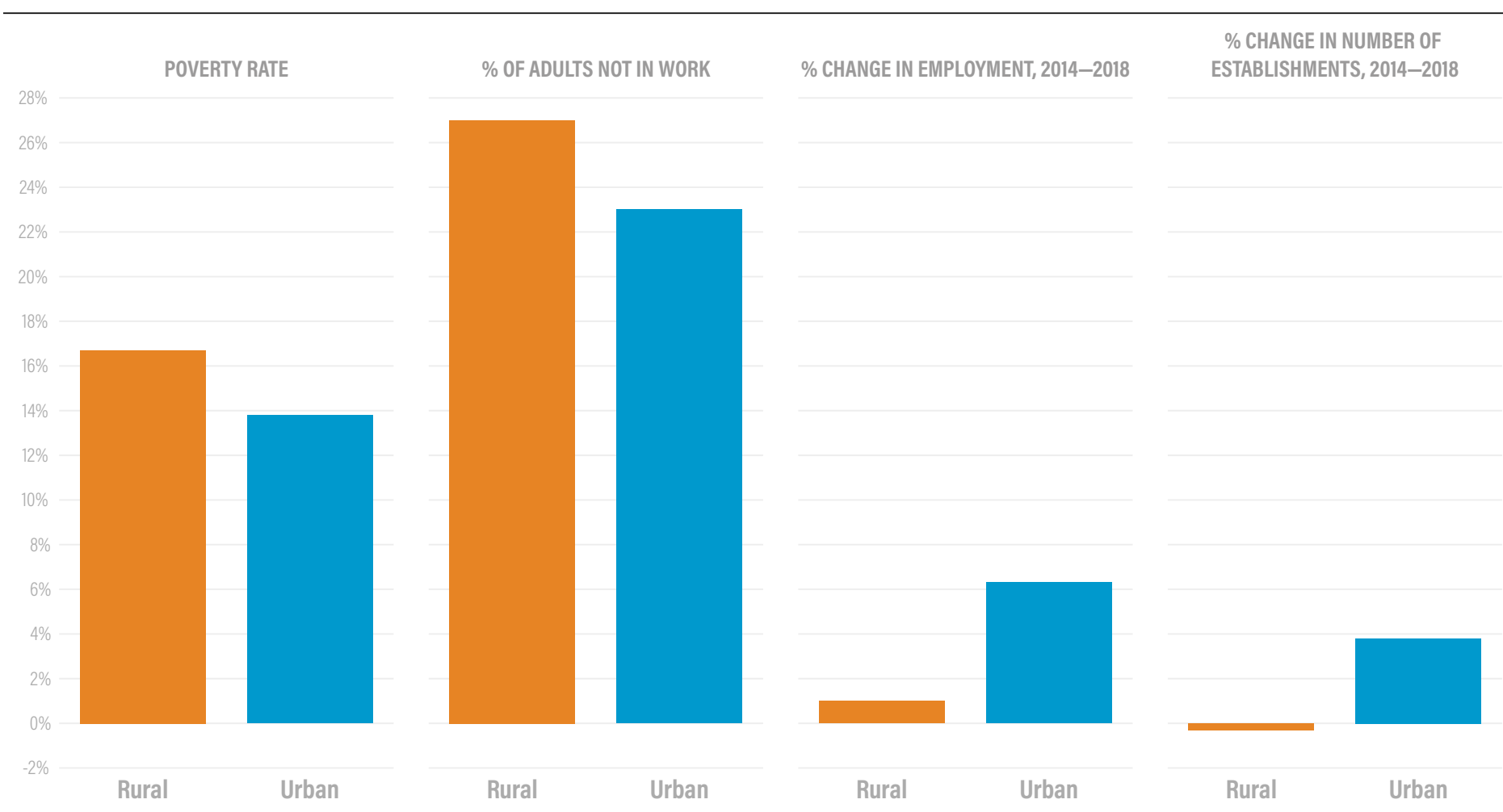

Source: Economic Innovation Group, Distressed Communities Index, 2020 
timber species, and these effects are projected to only increase. For rural areas dependent on recreation and tourism, climate change impacts like unpredictable snowfall and sea-level rise harm the resources and activities that draw visitors to the area (Hales et al. 2014). The devastating 2020 wildfire season in the western United States emphasized the increased threat of wildfire that accompanies a hotter, drier climate and endangers rural forest-adjacent communities.

Due in part to existing vulnerabilities, the COVID-19 pandemic has been particularly injurious for the economic health of rural areas. When the pandemic hit in 2020, rural employment had not yet fully recovered from the 2008-09 Great Recession, while urban areas had experienced a 9 percent growth relative to prerecession levels (Kopparam 2020). The slowdown in economic activity hit some rural areas severely given their higher reliance on industries such as farming, mining, food processing, and tourism, which are highly susceptible to pandemic-induced closures (Mueller et al. 2021). The pandemic has also hit rural communities disproportionately hard in key clean energy employment sectors including efficiency and renewable energy generation, with rural counties shedding more jobs as a share of total employment relative to their urban counterparts (Saha and Cyrs 2021).

Federal support for economic recovery in these communities is now a top priority, especially where these investments can simultaneously address the threat of climate change. Since rural areas tend to have higher poverty rates, have fewer employment opportunities, and be more susceptible to labor market shocks compared with urban areas, federal recovery policies should be designed to address rural communities' specific challenges and opportunities (Mueller et al. 2021). With state and local governments in many cases experiencing economic shocks in the wake of the pandemic and being forced to cut spending, a failure by the federal government to deliver substantial support to rural communities either directly or through subnational governments risks delaying economic recovery for years to come.

\section{Figure 2 | Clean Energy Jobs Are a Growing Economic Engine in Rural Counties}

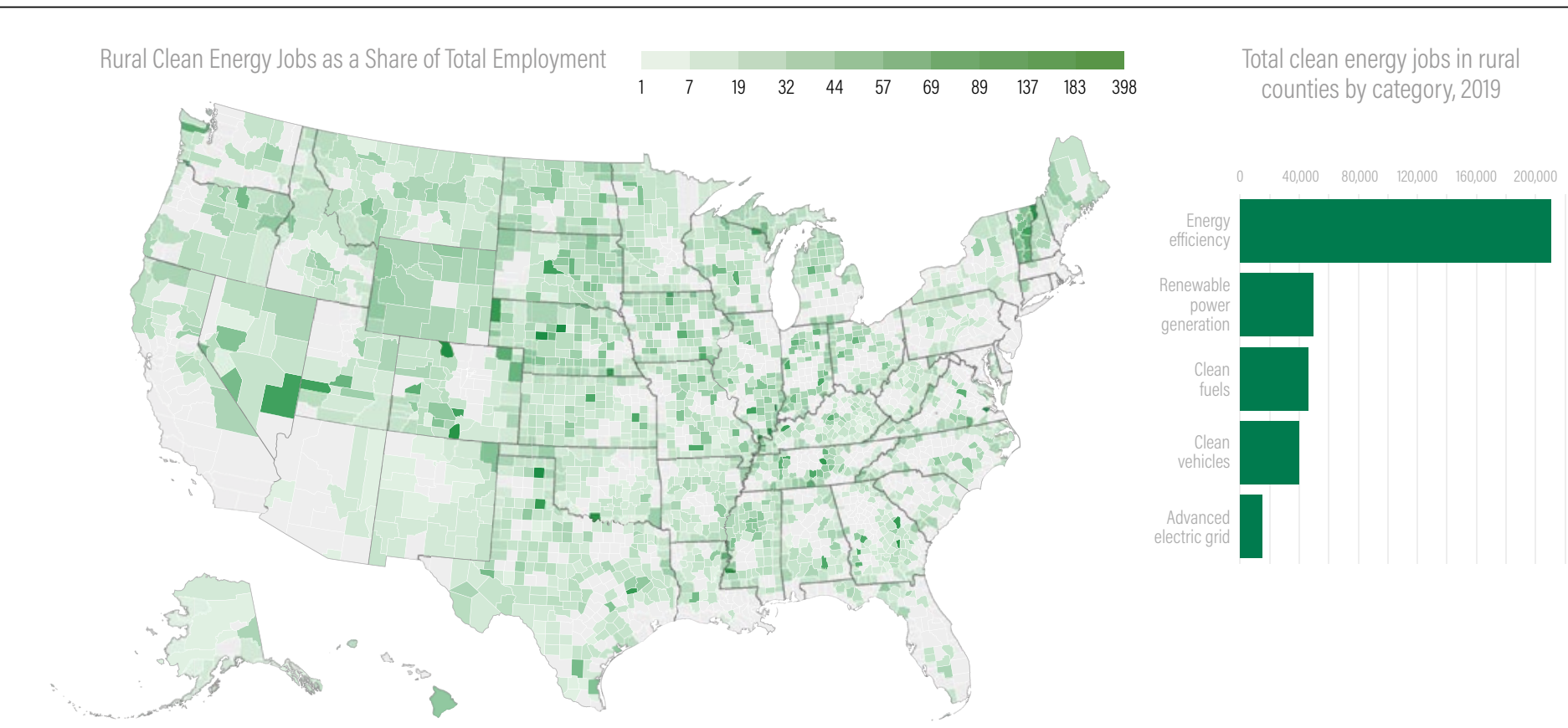

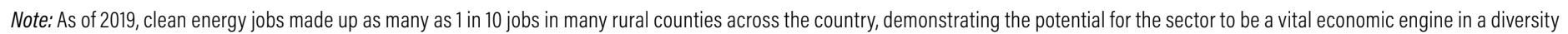

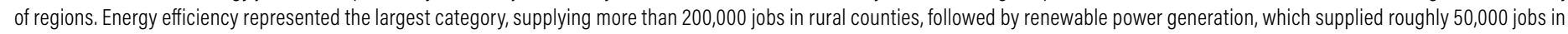
rural counties.

Source: Saha and Cyrs 2021. 


\subsection{New Climate Economy Opportunities in Rural} America

Investments in the new climate economy are both environmentally and economically sound prospects, with the potential to stimulate job growth and pave the way for long-term economic recovery from the COVID-19 pandemic (Saha and Jaeger 2020; E2 2020). Already, clean energy jobs make up a significant share of total employment in many rural communities (Figure 2), and this trend can be dramatically reinforced and expanded upon during the current decade. By one estimate, 600 gigawatts (GW) of new wind and solar projects projected to be built between 2020 and 2030 could generate US $\$ 220$ billion in economic benefits, primarily in rural areas, which host 99 percent of onshore wind and a growing share of utility-scale solar projects (Seigner 2021). Energy efficiency improvements can reduce rural households' energy burdens by 25 percent, representing more than $\$ 400$ in annual household savings (Ross et al. 2018). Restoration of trees and other natural ecosystems, which are concentrated in rural areas, generated $\$ 9.5$ billion annually in direct output and an additional $\$ 15$ billion in indirect spending prior to the pandemic (BenDor et al. 2015).

Clean energy occupations pay higher wages and pose lower formal educational barriers to entry than most jobs nationwide, offering an inclusive economic opportunity for rural workers (Muro et al. 2019). However, not all clean energy jobs offer higher pay or are more unionized than fossil fuel jobs, so policies must ensure a fair transition for fossil fuel workers and communities adversely impacted by the shift to a low-carbon economy.

Taken together, federal investment opportunities analyzed in this paper can make a meaningful contribution to addressing rural economic distress and the climate crisis. The investments considered here, however, will likely not be sufficient on their own to recruit and train the workforce necessary to implement new climate economy pathways. The policies recommended here will also need to include mechanisms to ensure that jobs created provide minimal barriers to entry, are well-paid, offer opportunities for stable employment and benefits, and support unionization. These components will help ensure that the new climate economy will not just create jobs, but sustain worker and community well-being and create equitable opportunities for all.

\section{KEY INVESTMENT AREAS FOR THE RURAL NEW CLIMIATE ECONOMY}

This analysis focuses on seven opportunities for federal investment across the United States that present significant potential for both rural job creation and emissions mitigation:

\section{Renewable energy}

Construction of wind, solar, and other renewable energy resources

\section{Energy efficiency improvements}

Technologies and processes that reduce energy consumption, lower energy bills, and decrease emissions in residential, commercial, and industrial buildings

\section{Energy transmission, distribution, and storage}

High-voltage transmission lines to integrate the growing share of renewable energy and accommodate increasing demand on the grid from electrification

Distribution networks that allow two-way communication between consumers and providers and enable new technologies that reduce cost and save electricity

$\square \quad$ Energy storage technologies to improve grid reliability, meet peak energy demand, and smooth the effects of variable energy resources

\section{Environmental remediation of abandoned fossil fuel infrastructure}

Cleaning up abandoned coal mines

Plugging and restoring orphaned oil and gas wells

\section{Tree restoration on federal lands}

Reforestation on ecologically appropriate federally owned lands by replanting native, climate-resilient species or enhancing natural regeneration

$\square \quad$ Restocking standing federal forests to natural densities where trees have been lost to disease, harvest, or natural disaster by planting trees and/ or promoting natural regrowth

\section{Tree restoration on non-federal lands}

Reforestation on ecologically appropriate state, local, or private lands by replanting or enhancing natural regeneration 
Restocking standing non-federal forests as described above

Integrating trees into pasture while maintaining livestock production through silvopasture systems

Integrating trees into cropland while maintaining crop production through agroforestry systems, including alley cropping systems and windbreaks

\section{Wildfire risk management}

Prescribed low-intensity burning

Selective thinning of small-diameter trees or other mechanical treatments designed to reduce fuel loads

These opportunities were selected based on three key criteria:

1. Providing significant potential for emissions mitigation and/or increasing resilience in rural communities

2. Offering an attractive return on investment by creating jobs and stimulating economic activity

3. Requiring federal investment to reach the scale needed to provide public benefits

The opportunities described above represent key investment needs for the new climate economy but are not meant to be comprehensive. Other strategies that may reduce emissions and create economic opportunities in rural communities include investments in electric vehicle manufacturing and infrastructure, carbon removal infrastructure like carbon dioxide pipelines and geologic storage wells, and technologies to reduce GHG emissions from agricultural operations, among others. Given its exploratory nature, this initial analysis considers only a limited set of clean energy and land sector decarbonization scenarios. Future work will explore federal investment in additional areas and the potential economic impact on rural communities.

\section{APPROACH TO ESTIMATING RURAL ECONOMIC IMPACTS}

This assessment quantifies the potential economic benefits of federal investments in seven areas of the new climate economy in rural counties. We evaluated and identified opportunities with significant climate benefits and job creation potential, and then determined investment levels required to scale up or expand each opportunity in rural counties. For opportunities in the energy sector, we modeled the economic impacts from an illustrative portfolio of renewable energy, energy efficiency, and transmission, distribution, and storage (TDS) policies and programs. We determined investment needs based on a review of historical funding for existing policies and additional funding needs derived from expert consultation and proposed legislation. We also estimated the leverage effect of federal investment in renewable energy, energy efficiency, and TDS scenarios, and the model includes assumed additional state, local government, and private sector spending. It is important to note though that our leverage assumptions are very conservative and the economic impacts for the three energy sectors result primarily from federal investment. For full detail on the investment level and leverage assumed for each program and policy contained in renewable energy, energy efficiency, and TDS analyses, refer to Appendix J.

The investment needs associated with environmental remediation for abandoned fossil fuel infrastructure are based on total cost of remediation and restoration activities as opposed to specific policies. For full detail on the investment level assumed for orphaned oil and gas wells and abandoned coal mines, refer to Appendix J.

For opportunities in the land sector, we estimated investment needs based on the total cost of achieving desired results across ecologically suitable areas without displacing food or fiber production, rather than basing inputs on specific policies. This analysis derived modeling inputs from county-level data on acreage of opportunity for each land sector pathway; and average cost of implementation per acre. Restocking opportunities were considered only in eastern states with low risk of wildfire and without the concerns of excessive fuel loads that are present in western forests. For more information on methodologies for deriving opportunity acreage and cost, see Appendix K.

Table 1 summarizes the federal investment amounts in the seven areas of the new climate economy, including the assumed rural shares. 
Table 1 | Annual Federal Investment in Seven Areas of New Climate Economy and Rural Share

\begin{tabular}{|c|c|c|}
\hline INVESTMENT AREA & $\begin{array}{l}\text { ANNUAL } \\
\text { FEDERAL } \\
\text { INVESTMENT (\$, } \\
\text { BILLIONS) }\end{array}$ & $\begin{array}{l}\text { RURAL SHARE } \\
\text { (S, BILLIONS) }\end{array}$ \\
\hline Renewable energy & $\$ 18.8$ & $\$ 3.8$ \\
\hline Energy efficiency & $\$ 8.3$ & $\$ 2.1$ \\
\hline $\begin{array}{l}\text { Transmission, distribution, and } \\
\text { storage }\end{array}$ & $\$ 19.6$ & $\$ 3.4$ \\
\hline $\begin{array}{l}\text { Environmental remediation } \\
\text { of abandoned fossil fuel } \\
\text { infrastructure }\end{array}$ & $\$ 2.4$ & $\$ 1.3$ \\
\hline Tree restoration on federal lands & $\$ 0.45$ & $\$ 0.35$ \\
\hline $\begin{array}{l}\text { Tree restoration on non-federal } \\
\text { lands }\end{array}$ & $\$ 4.3$ & $\$ 2.8$ \\
\hline Wildfire risk management & $\$ 1.5$ & $\$ 1.1$ \\
\hline All seven areas & $\$ 55.4$ & $\$ 14.9$ \\
\hline
\end{tabular}

Source: WRI authors and BW Research.

Subsequently, BW Research, commissioned by World Resources Institute, used the Economic Impact Analysis for Planning (IMPLAN) input-output economic model to estimate the direct, indirect, and induced effects on jobs; economic value added; employee compensation (e.g., wages, salaries); and local, state, and federal taxes generated nationally and in rural counties. See the glossary for definitions.

We estimate economic impacts in the energy sector for the first five years of robust federal clean energy spending while those in the land sector are distributed over 20 years. This longer time horizon for investment in tree restoration and wildfire mitigation reflects the need for long-term forest management to ensure forest health and tree survival for reforestation and restocking projects, and adequate mitigation of wildfire risk.

We assumed that for each of the seven investment areas, a certain share of the modeled federal investment went to rural counties. We determined this based on a number of factors including existing clean energy county-level labor trends, historical geographic funding patterns, and the geography of a given sector (e.g., location of abandoned coal mines, documented orphan oil and gas wells, or federal forests). For programs targeting rural areas specifically, we allocated the entire federal investment to rural counties in the state. Finally, for the renewable energy, energy efficiency, and TDS sectors only, we made an additional assumption that at least 15 percent of modeled investment would flow to rural counties. We used 15 percent as a modeling construct for the minimum share going to rural areas. This assumption is intended to illustrate the potential if federal investments were allocated to rural areas at a more equitable level; however, it is likely that targeted complementary policies would be required to ensure that funding actually reaches certain regions. At the same time, a rural allocation of funds could be even higher than this minimum share, driven by policy goals to advance racial and economic equity within rural areas and between rural and urban areas. A more detailed description of these methodologies can be found in Appendix $\mathrm{J}$.

To assess the impact of new climate economy investments on economically disadvantaged rural communities, we used the Economic Innovation Group's Distressed Communities Index (DCI), which uses aggregated employment and wealth metrics to identify economically disadvantaged rural counties (Figure 3). DCI sorts U.S. counties into five quintiles using seven metrics: poverty rate, percent of adults that have not graduated high school, percent of unoccupied housing units controlled for vacation homes, median household income, change in number of employees working in the county from 2014 to 2018, change in number of establishments located in the county from 2014 to 2018, and percent of adults ages 25-54 that are not in the workforce. In this paper, we focus on rural counties in the fourth (at-risk counties) and fifth (distressed counties) quintiles of the DCI to highlight the economic impacts of federal investment on those rural counties. The DCI, and by extension this paper, does not include components for race and public health associated with pollution. Further research should investigate the potential impact of investment on communities and workers of color as well as environmental justice communities. $^{1}$

Our analysis primarily examines benefits from federal investments in rural areas and our leverage assumptions for private sector investment are conservative. In reality, though, any of the investment areas we analyzed, including renewable energy and TDS, also experience high levels of private investment. For those, our results may represent only a portion of the job creation and economic benefits that can be realized in the coming years. Despite 


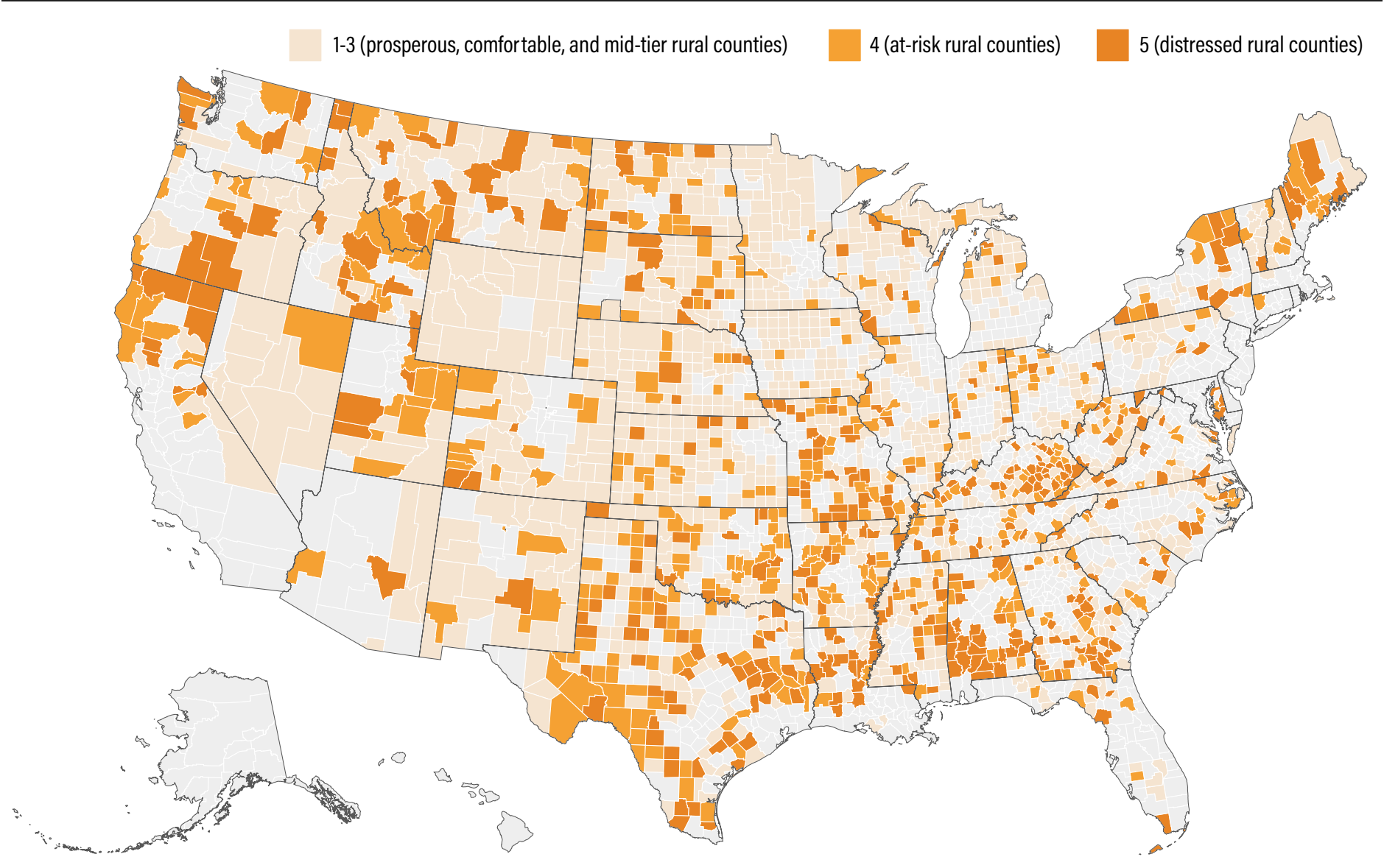

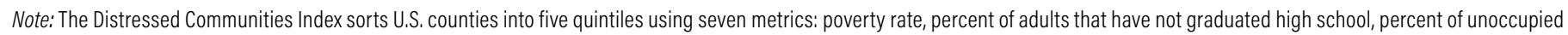

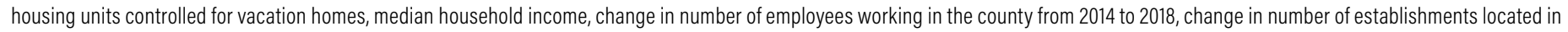

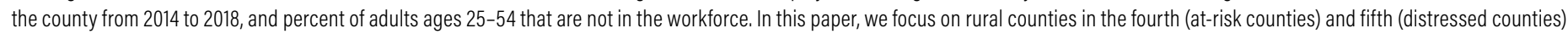
quintiles of the $\mathrm{DCl}$ to highlight the economic impacts of federal investment on those rural counties.

$D C l=$ Distressed Communities Index.

Source: Economic Innovation Group, Distressed Communities Index, 2020.

this, federal investments have a major role to play in catalyzing economic growth and creating rural jobs for all sectors in the new climate economy.

\section{RURAL ECONOMIC BENEFITS OF THE NEW CLIMATE ECONOMY}

An annual federal investment of $\$ 55$ billion in the seven areas of the new climate economy in the first five years, with $\$ 14.9$ billion directed to rural counties, would create nearly 260,000 direct, indirect, and induced jobs in rural communities that would last for at least five years (a total of 1.3 million job-years) and 740,000 jobs across the United States (a total of 3.7 million job-years). ${ }^{2}$ This investment translates to 17.5 jobs created per $\$ 1$ million invested in rural counties, compared with 13.5 jobs created per $\$ 1$ million nationally.

This level of investment would also lead to $\$ 21.7$ billion in value added or increased gross domestic product (GDP) per year for rural economies, representing $\$ 1.46$ for every dollar invested. This includes $\$ 12.9$ billion in employee compensation and $\$ 1.6$ billion in tax revenues (see Table 2). Nationally, the added value from these investments would total $\$ 72.2$ billion annually- $\$ 1.31$ per dollar spent. Table 3 shows the distribution of economic benefits across the seven investment areas in the new climate economy. 
In terms of annual job creation, we estimate that California, Texas, New Mexico, Missouri, and Wyoming would see the greatest benefit in absolute terms in their rural counties (Figure 4). California and Texas would see significant job gains in part due to the current size of their clean energy workforces, which we used as one of the modeling assumptions to allocate economic impacts across states. While California sees more than half of this job gain from investment in wildfire risk management, federal investments in renewable energy and transmission, distribution, and storage sectors contribute to more than 60 percent of Texas's job creation.

Investment in wildfire risk management also comprises a significant share of New Mexico's and Wyoming's total job creation potentials. When looking at the results on a normalized basis (rural jobs created as a share of total employment), California, New Mexico, and Wyoming are still in the top five states, but Massachusetts and Nevada also emerge as leaders (Figure 5). Investments in transmission, distribution, and storage drive job creation in both these states.

\section{Table 2 | Rural and National (Rural and Urban) Economic Impacts from Federal Investments in Seven Areas of the New}

\section{Climate Economy}

\begin{tabular}{|c|c|c|c|c|}
\hline & RURAL & NATIONAL & RURAL & NATIONAL \\
\hline & $\begin{array}{l}\text { IMPACTS PER YEAR FOR } \\
5 \text { YEARS (MILLIONS) }\end{array}$ & $\begin{array}{l}\text { IMPACTS PER YEAR FOR } 5 \\
\text { YEARS (MILLIONS) }\end{array}$ & $\begin{array}{l}\text { TOTAL PER YEAR FOR } 5 \\
\text { YEARS (MILLIONS) }\end{array}$ & $\begin{array}{l}\text { TOTAL PER YEAR FOR } 5 \\
\text { YEARS (MILLIONS) }\end{array}$ \\
\hline Direct jobs & 142,892 & 362,575 & & \\
\hline Indirect jobs & 53,463 & 170,638 & 259,441 & 743,686 \\
\hline Induced jobs & 63,083 & 210,473 & & \\
\hline Direct value added & $\$ 10,283$ & $\$ 32,987$ & & \\
\hline Indirect value added & $\$ 6,201$ & $\$ 22,192$ & $\$ 21,732$ & $\$ 72,165$ \\
\hline Induced value added & $\$ 5,248$ & $\$ 16,986$ & & \\
\hline Direct employee compensation & $\$ 7,262$ & $\$ 20,727$ & & \\
\hline Indirect employee compensation & $\$ 2,953$ & $\$ 10,804$ & $\$ 12,935$ & $\$ 39,950$ \\
\hline Induced employee compensation & $\$ 2,720$ & $\$ 8,419$ & & \\
\hline Local taxes & $\$ 416$ & $\$ 1,851$ & & \\
\hline State taxes & $\$ 426$ & $\$ 1,783$ & $\$ 1,632$ & $\$ 6,314$ \\
\hline Federal taxes & $\$ 788$ & $\$ 2,680$ & & \\
\hline
\end{tabular}

Source: WRI authors and BW Research. 


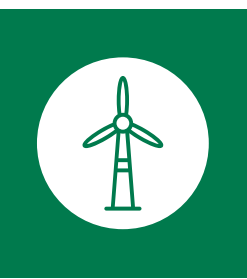

\section{RENEWABLE ENERGY}

$\$ 18.8$ billion annually in federal investment, with $\$ 3.8$ billion going directly to rural counties, would result in the following:

$\cdot 31,600$ direct, indirect, and induced jobs

- $\$ 3.4$ billion in value added to rural economies

- \$1.7 billion in employee compensation

- \$536 million in total tax revenues

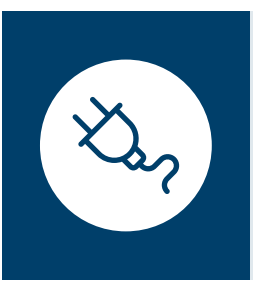

\section{ENERGY EFFICIENCY}

$\$ 8.3$ billion annually in federal investment, with $\$ 2.1$ billion going directly to rural counties, would result in the following:

$\cdot 29,800$ direct, indirect, and induced jobs

- \$2.9 billion in value added to rural economies

- \$1.6 billion in employee compensation

- \$162 million in total tax revenues

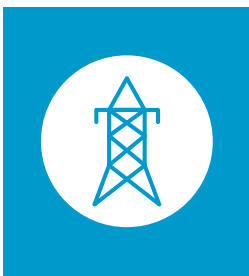

\section{TRANSMISSION, DISTRIBUTION, AND STORAGE}

$\$ 19.6$ billion annually in federal investment, with $\$ 3.4$ billion going directly to rural counties, would result in the following:

- 48,800 direct, indirect, and induced jobs

- $\$ 5.8$ billion in value added to rural economies

- \$3.1 billion in employee compensation

- \$362 million in total tax revenues

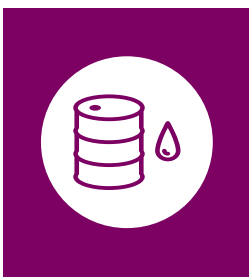

\section{ENVIRONMENTAL REMEDIATION OF ABANDONED FOSSIL FUEL INFRASTRUCTURE}

$\$ 2.4$ billion annually in federal investment, with $\$ 1.3$ billion going directly to rural counties, would result in the following:

- 14,600 direct, indirect, and induced jobs

- \$2 billion in value added to rural economies

- \$952 million in employee compensation

- \$164 million in total tax revenues

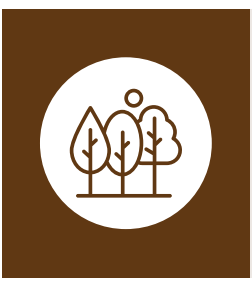

\section{TREE RESTORATION ON FEDERAL LANDS}

$\$ 445$ million annually in federal investment, with 350 million going directly to rural counties, would result in the following:

-9,200 direct, indirect, and induced jobs

- $\$ 474$ million in value added to rural economies

- \$330 million in employee compensation

-\$12 million in total tax revenues

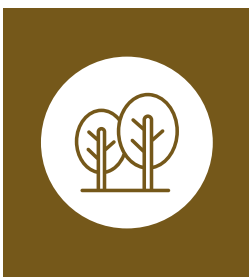

\section{TREE RESTORATION ON NON-FEDERAL LANDS}

$\$ 4.3$ billion annually in federal investment, with $\$ 2.8$ going directly to rural counties, would result in the following:

$\cdot 76,200$ direct, indirect, and induced jobs

- $\$ 3.9$ billion in value added to rural economies

- $\$ 2.7$ billion in employee compensation

-\$211 million in total tax revenue

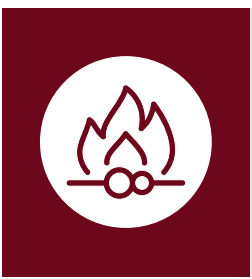

\section{WILDFIRE RISK MANAGEMENT}

$\$ 1.5$ billion annually in federal investment, with $\$ 1.1$ billion going directly to rural counties, would result in the following:

- 49,200 direct, indirect, and induced jobs

- $\$ 3.3$ billion in value added to rural economies

- \$2.5 billion in employee compensation

- \$182 million in total tax revenues

Source: WRI authors and BW Research. 
Figure 4 | Geographic Distribution of Rural Job Creation (Jobs per' Year')
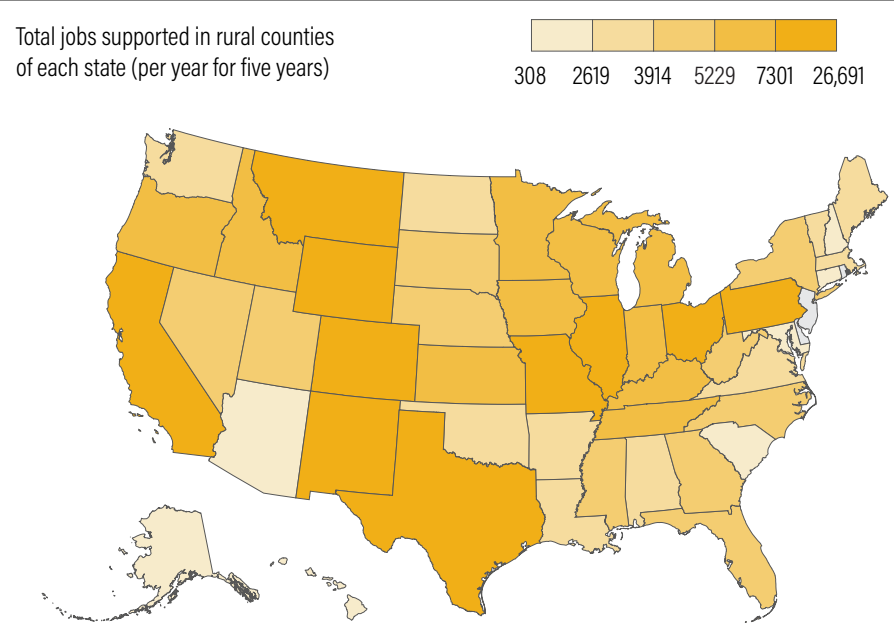

Note: Delaware, the District of Columbia, New Jersey, and Rhode Island do not have any rural counties as defined by the U.S. Department of Agriculture.

Source: WRI authors and BW Research.

\section{Figure 5 | Geographic Distribution of Rural Job Creation (per 1,000 Workers)}

\begin{tabular}{l|ll|l|l|l|l|}
\hline & & & & & & \\
\hline $\begin{array}{l}\text { Jobs supported in rural counties per 1,000 } \\
\text { private sector workers (per year for five years) }\end{array}$ & 0.0 & 7.70 & 9.7 & 14.8 & 24.4 & 94.6 \\
\hline
\end{tabular}

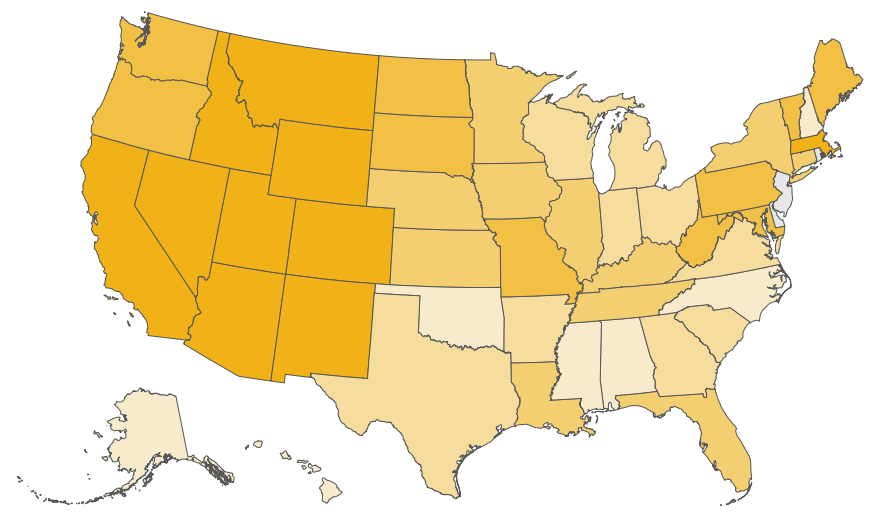

Note: Delaware, the District of Columbia, New Jersey, and Rhode Island do not have any rural counties as defined by the U.S. Department of Agriculture.

Source: WRI authors and BW Research.

The following sections outline the economic benefits from seven areas for federal investment and offer recommendations for policy vehicles to convey investment to rural communities.

\subsection{Renewable Energy}

\section{The Issue}

Over the last decade, investment in renewable electricity technologies has risen thanks to reduced technology costs coupled with state and federal policy incentives. Since 2010, cumulative installed renewable capacity has more than doubled, and renewables now make up approximately 20 percent of total electricity generation (EIA 2020a; BNEF 2021). Investment in renewable energy exceeded $\$ 60$ billion in 2019 , with most accruing to wind and solar (BNEF 2021).

Despite the encouraging growth, renewable energy has not been immune to recent pandemic-induced shocks, with total investments falling by $\$ 7$ billion in 2020 (BNEF 2021). This decline poses a challenge to meeting ambitious climate goals. Annual renewable capacity additions must double in the coming years-from $33 \mathrm{GW}$ in 2020 to upwards of $60 \mathrm{GW}$ over the next decade-and maintain this growth rate to be on pace for 90 percent clean electricity by 2035 (UCB 2020a).

\section{Box 2 | Economic Impacts from Rush Creek Wind Farm in Colorado}

The 600 megawatt (MW) Rush Creek Wind Farm spans four rural counties in eastern Colorado. The project is owned and operated by Xcel Energy and came online in 2018. An economic impact analysis conducted by the

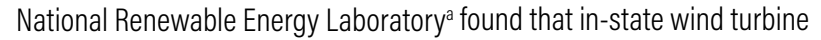
manufacturing and installation can lead to significant economic benefits for these rural communities. The project's 300 2-MW wind turbines were manufactured in Colorado by Vestas. In addition to jobs created during construction of the wind farm, Rush Creek supports an estimated 180 long-term jobs and will provide $\$ 20$ million in gross domestic product annually during its anticipated 25-year lifespan. Furthermore, the project expects to generate about $\$ 45$ million in landowner lease payments and $\$ 62.5$ million in property taxes over its lifetime. Lease payments provide additional income support to farmers and ranchers and enhance financial stability during periods when either bad weather hits or commodity prices are low. Property taxes can provide funding for schools, libraries, fire departments, and other infrastructure projects.

Note: '. Stefek et al. 2019. 


\begin{tabular}{|l|l|l|l|l|l|}
\hline & $\begin{array}{l}\text { JOBS PER YEAR FOR 5 } \\
\text { YEARS }\end{array}$ & $\begin{array}{l}\text { VALUE ADDED PER YEAR } \\
\text { FOR 5 YEARS } \\
\text { (\$, MILLIONS) }\end{array}$ & $\begin{array}{l}\text { EMPLOYEE COMPENSATION } \\
\text { PER YEAR FOR 5 YEARS } \\
\text { (\$, MILLIONS) }\end{array}$ & $\begin{array}{l}\text { TAXES ON PRODUCTION } \\
\text { AND IMPORTS PER YEAR } \\
\text { FOR 5 YEARS } \\
\text { (S, MILLIONS) }\end{array}$ \\
\hline Direct effects & 11,700 & $\$ 1,469$ & $\$ 761$ & Local & $\$ 226$ \\
\hline Indirect effects & 6,500 & $\$ 1,206$ & $\$ 555$ & State & $\$ 189$ \\
\hline Induced effects & 13,400 & $\$ 726$ & $\$ 348$ & Federal & $\$ 121$ \\
\hline Total & $\mathbf{3 1 , 6 0 0}$ & $\$ \mathbf{3}, 401$ & $\$ 1,664$ & Total & $\$ 536$
\end{tabular}

Note: Assumed investment of $\$ 3.8$ billion per year over five years to rural areas.

Source: WRI authors and BW Research.

Renewable energy can drive job growth and economic benefits in rural communities, as exemplified in Box 2. From 2017 to 2019, renewable energy jobs in rural counties grew by 20 percent, adding roughly 10,000 new jobs and accounting for the majority of employment growth in the sector nationwide (Saha and Cyrs 2021). At the same time, the renewable energy sector still represents a smaller share of total employment in rural counties than it does in urban ones, and this trend has been exacerbated by recent economic shocks.

\section{Figure 6 | Geographic Distribution of Rural Job Creation from Federal Renewable Energy Investment:}

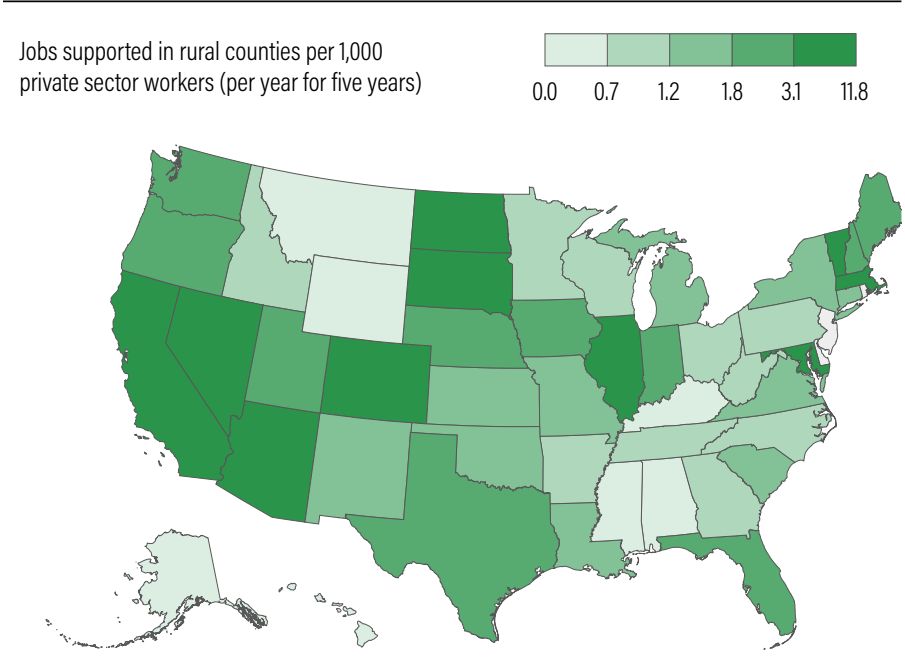

Note: Delaware, the District of Columbia, New Jersey, and Rhode Island do not have any rural counties as defined by the U.S. Department of Agriculture.

Source: WRI authors and BW Research.

\section{The Rural Economic Opportunity}

We examine the impact of $\$ 18.8$ billion in federal investment per year over the next five years in renewable energy, based on opportunities to extend existing federal policies and accelerate technology deployment. Of this, $\$ 3.8$ billion would flow directly to rural communities.

This level of federal investment would support nearly 32,000 direct, indirect, and induced jobs that would last for at least five years (160,000 job-years) in rural communities. The majority of these jobs would be in construction, manufacturing, and professional, scientific, and technical services industries. This level of federal investment would also add $\$ 3.4$ billion in annual value to rural economies for five years including $\$ 1.7$ billion in annual employee compensation and \$536 million in local, state, and federal taxes (Table 4). States seeing the most significant economic benefits in rural areas would include Texas, California, Illinois, Iowa, and Colorado, which together would account for over a third of total job creation. On a normalized basis (jobs created as a share of total employment), Massachusetts, California, Nevada, Maryland, and Illinois rank among the top five states (Figure 6). Note: For detailed outputs by state, see Appendix B. 


\section{The Federal Policy Opportunity}

Federal investments could be channeled through a combination of well-established policy vehicles, with renewed and/or enhanced incentive structures relative to recent years. These include tax incentives for manufacturing, deployment, and generation as well as targeted grant and loan financing for rural communities.

Specific policies that can play a role in accelerating renewable energy in rural America include the following:

Extending the federal investment tax credit (ITC) of 30 percent for offshore wind, solar, and other renewables

Extending the federal production tax credit for wind and other renewables

- Renewing the advanced manufacturing tax credit (tax code section 48C) for 30 percent of investments in facilities that produce clean energy products including renewable energy generation technologies and their components
Expanding grant and loan programs targeted at rural communities, including the USDA Rural Energy for America Program (REAP) program ${ }^{3}$

To ensure that underserved communities are at the fore of federal investment strategies and that benefits accrue equitably, states, local governments, and other key implementing partners can adopt complementary provisions. Such measures can include requirements that a certain share of funding is allocated to economically disadvantaged communities, sales tax exemptions for projects that use community workforce agreements and/ or prioritize hiring from economically disadvantaged communities, and other incentives.

\subsection{Energy Efficiency \\ The Issue}

Investing in energy efficiency remains one of the most reliable strategies for lowering emissions in the United States and will be vital for decarbonization moving forward. Energy efficiency measures alone can cut U.S. energy use and GHG emissions in half by 2050, with

Figure 7 | IIlustration of Federal Energy Efficiency Investment and Associated Benefits for Rural Areas

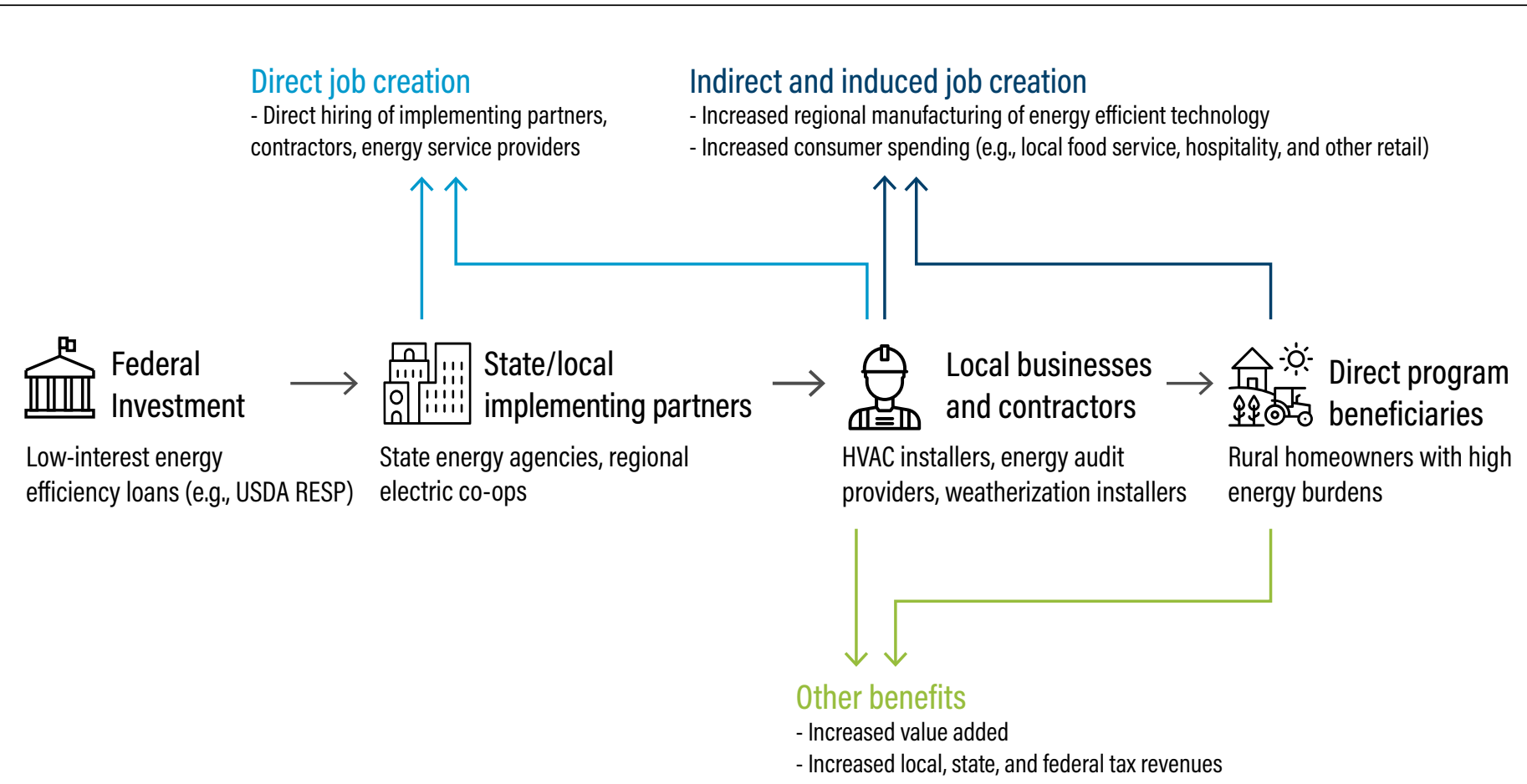

Note: USDA RESP = U.S. Department of Agriculture Rural Energy Savings Program; co-op = cooperative; HVAC = heating, ventilation, and air conditioning. 


\section{Table 5 | Rural Economic Impacts from Federal Energy Efficiency Investments}

\begin{tabular}{|l|l|ll|l|l|}
\hline & $\begin{array}{l}\text { J0BS PER YEAR FOR } \\
\text { 5 YEARS }\end{array}$ & $\begin{array}{l}\text { VALUE ADDED } \\
\text { PER YEAR FOR 5 } \\
\text { YEARS } \\
\text { (\$, MILLIONS) }\end{array}$ & $\begin{array}{l}\text { EMPLOYEE COMPENSATION PER } \\
\text { YEAR FOR 5 YEARS } \\
\text { (S, MLLIONS) }\end{array}$ & $\begin{array}{l}\text { TAXES ON PRODUCTION } \\
\text { AND IMPORTS PER } \\
\text { YEAR FOR 5 YEARS } \\
\text { (S, MILLIONS) }\end{array}$ \\
\hline Direct effects & 13,600 & $\$ 1,299$ & $\$ 794$ & Local & $\$ 28$ \\
\hline Indirect effects & 8,800 & $\$ 940$ & $\$ 495$ & State & $\$ 35$ \\
\hline Induced effects & 7,400 & $\$ 675$ & $\$ 325$ & Federal & $\$ 98$ \\
\hline Total & $\mathbf{2 9 , 8 0 0}$ & $\mathbf{\$ 2 , 9 1 4}$ & $\mathbf{\$ 1 , 6 1 3}$ & Total & $\$ 162$
\end{tabular}

Note: Assumed investment of $\$ 2.1$ billion per year over five years to rural areas

Source: WRI authors and BW Research.

efficiency measures for buildings and industry in particular comprising roughly 60 percent of this potential (Nadel and Ungar 2019).

Despite the vital importance of energy efficiency investment, rural communities often face persistent underinvestment in energy efficiency relative to their urban counterparts. Rural households across the country have a disproportionately high energy burden, due to interrelated factors including low population density, lack of local capacity from energy services contractors, and the limited financial capacity of rural electric cooperatives (Shoemaker et al. 2018).

Investment in energy efficiency is also lagging. Prior to the COVID-19 pandemic, energy efficiency spending in the United States had stagnated, and investment in energy efficiency is estimated to have fallen globally by 9 percent in 2020 (EIA 2020b; IEA 2020). In recent years, annual U.S. spending on efficiency has been estimated at \$60-115 billion (Nadel 2017). However, significant, far greater potential is both achievable and necessary to reach ambitious climate commitments and bolster economic growth.

\section{The Rural Economic Opportunity}

We examined the impact of $\$ 8.3$ billion in federal investment per year over the next five years in energy efficiency upgrades for homes, commercial buildings, industrial facilities, and farms across the country. Of this total, an estimated $\$ 2.1$ billion would flow directly to rural counties. Figure 7 illustrates an example of how such efficiency investments can flow to rural areas, generating jobs, value added, and other local or regional benefits, and a more detailed case study is provided in Box 3 .

This level of federal investment would support approximately 30,000 direct, indirect, and induced jobs annually in rural counties, including in the energy services, construction, and engineering sectors, that would

\section{Figure 8 | Geographic Distribution of Rural Job Creation from Federal Energy Efficiency Investments}

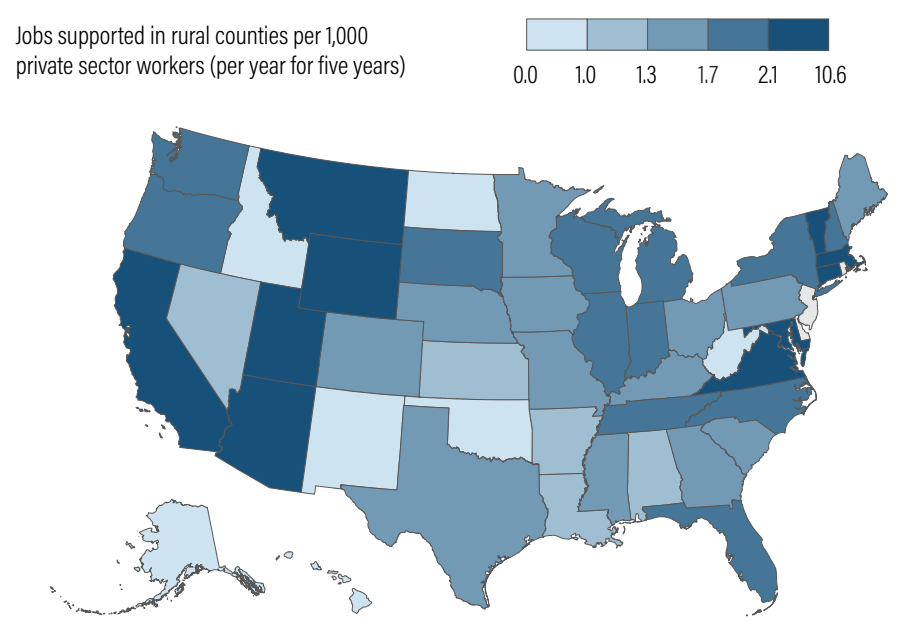

Note: Delaware, the District of Columbia, New Jersey, and Rhode Island do not have any rural counties as defined by the U.S. Department of Agriculture.

Source: WRI authors and BW Research. 
last for at least five years (150,00o job-years). Rural economies would also accrue $\$ 2.9$ billion in annual value added for five years, including $\$ 1.6$ billion in annual employee compensation and \$162 million in local, state, and federal taxes (Table 5). States that would see the most significant job creation benefits include California, Texas, Ohio, North Carolina, and Michigan, accounting for over a quarter of rural jobs added. On a normalized basis (jobs created as a share of total employment), Massachusetts, Maryland, California, Connecticut, and Vermont would stand to gain the most (Figure 8). Note: For detailed outputs by state, see Appendix C.

\section{Box 3 | Energy Efficiency Investment in Rural South Carolina}

Electric cooperatives (co-ops) are an integral part of America's rural communities. Co-ops often serve regions where a significant portion of customers are at or below the poverty level and lack resources to invest in efficiency upgrades, more efficient heating and cooling, or weatherization.

To help resolve these issues, Santee Electric Co-0p, which operates in four rural counties in South Carolina, has used an on-bill financing program called Help My House to fund energy efficiency upgrades for homes and small businesses. Members receive low-interest loans that are paid back on their monthly utility bills with terms of up to 10 years. To date, Santee has weatherized over 300 homes, without any defaults on loans. While initially the utility put up its own capital to implement the program, Santee has since been able to leverage an additional $\$ 2.5$ million in loan financing from the U.S. Department of Agriculture Rural Energy Savings Program, allowing it to reach an even broader share of its customers with much needed efficiency upgrades. Through the program, members have reduced energy use by an average of 30 percent, significantly lowering their bills. The program creates local jobs including electric co-op staff to implement the program, local energy auditors, and contractors to make the upgrades. Consumers are also able to reinvest their energy savings, further benefiting the local economy.

Source: Information provided to WRI authors by James W. Kirby Jr., Vice President of Public Affairs, Santee Electric Cooperative, 2021.

\section{The Federal Policy Opportunity}

These economic benefits can be achieved through a combination of targeted tax incentives and block grant programs. In many cases, such programs are well established and received appropriations following the 2009 financial crisis comparable to those envisioned in this analysis.
Specific energy efficiency policies that could provide economic benefits to rural communities include the following:

Extending and enhancing incentives for efficiency upgrades in homes and residential buildings, including the existing homes tax credit (tax code section 25C) and new homes tax credit (sec. 45L)

- Enhancing tax incentives for efficiency upgrades in new and existing commercial buildings (sec. 179D)

- Expanding efficiency block grant programs that channel money directly to state and local agencies for targeted upgrades, including the Weatherization Assistance Program (WAP), State Energy Program (SEP), and Energy Efficiency Conservation Block Grants program

- Establishing a comparable block grant program for industrial facilities

Expanding grant and loan programs targeted at rural communities in particular, including USDA REAP, the Energy Efficiency Conservation Loan Program, and the Rural Energy Savings Program

To ensure that these investments achieve tangible results in rural communities, complementary policies at the federal, state, and local levels may also be required. Historically, rural communities have tended to benefit less from energy efficiency measures than their urban counterparts, in part due to a lack of on-the-ground contractors and the added cost of making upgrades in remote areas (Shoemaker et al. 2018). Greater investment in job training and capacity building is therefore required as a complement to the above programs and policies.

\subsection{Transmission, Distribution, and Storage The Issue}

The aging and fragmented electric transmission and distribution grid in the United States has suffered from decades of underinvestment, creating an opportunity for new investments that not only address safety and reliability concerns but also pave the way for the integration of next-generation clean technologies. Grid modernization will enable the integration of increasing levels of renewable generation capacity, optimization of supply and demand across long distances, and management of heightened demand from electric vehicles and appliances, all of which will be vital to addressing climate change. These investments can create major economic opportunities, including in rural communities. 
Transmission facilities obtain 82 percent of construction services, materials, and equipment domestically, creating U.S. manufacturing and construction jobs (WIRES 2011).

Expanded transmission is critical to any plans to decarbonize the power sector, with one analysis finding that transmission infrastructure would have to be doubled to decarbonize the power sector in a cost-effective manner (Brown and Botterud 2021). Fortunately, studies find that investing in grid modernization would be both economically and technologically feasible, effectively paying for itself many times over given the numerous co-benefits (UCB 2020b). Box 4 describes the economic benefits to four Midwest states from a recently approved transmission line, highlighting just one promising case.

\section{The Rural Economic Opportunity}

We examined the impact of $\$ 19.6$ billion in federal investment in the transmission, distribution, and storage sector per year over a five-year period, with approximately $\$ 3.4$ billion flowing directly to rural communities.

The construction, engineering, and financing associated with this investment would create nearly 50,000 rural jobs each year that would last for at least five years $(250,000$ job-years). The investment would also yield $\$ 5.8$ billion in value added for rural economies each year for five years, including $\$ 3.1$ billion in employee compensation and $\$ 362$ million in tax revenues (see Table 6). California,
Box 4 | Grain Belt Express Transmission Line to Bring Wind Power and Economic Benefits to Midwest States

Covering nearly 800 miles through Kansas, Missouri, Illinois, and Indiana, the Grain Belt Express transmission line is projected to deliver 4,000 megawatts of low-cost wind power from western Kansas to millions of Americans in the Midwest. Analysis commissioned by Invenergy, the project developer, estimates that the project will create hundreds of jobs and bring billions in economic investment and energy savings, with significant impact in rural areas. ${ }^{a}$ According to the analysis, Grain Belt Express will create nearly 22,500 temporary jobs over a three-year construction period, 968 full-time jobs after that, and $\$ 8$ billion in economic investment in Kansas alone. ${ }^{\mathrm{b}}$ The line will traverse 14 counties in Kansas, of which all except one are rural, meaning most of the economic benefits will accrue to rural counties. The project will save $\$ 7$ billion in electricity costs for Kansas and Missouri consumers (savings of $\$ 50 /$ year for the average residential customer) through 2045. In addition to moving clean energy, Invenergy is committing to providing broadband access to rural communities along the line route. In Missouri, for instance, about 250,000 rural homes, schools, and hospitals within 50 miles of the transmission line that lack broadband access will benefit from the proposed expansion of broadband infrastructure, at no additional cost to taxpayers.

Notes:

a. Invenergy n.d.

b. Invenergy n.d.

Table 6 | Rural Economic Impacts from Federal Investments in Transmission, Distribution, and Storage

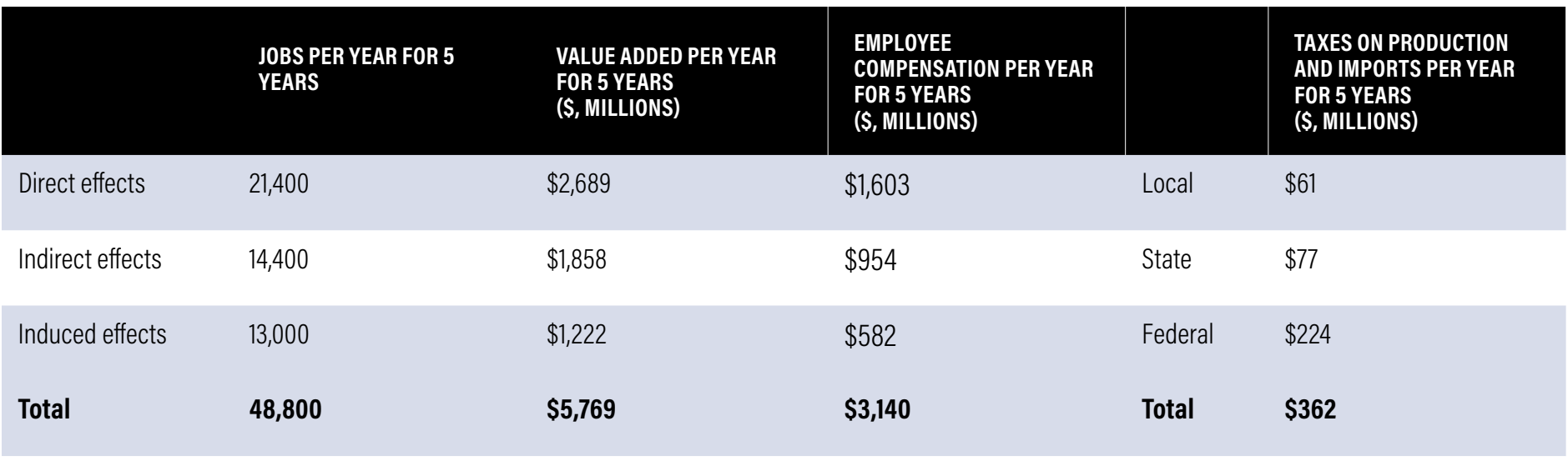

Note: Assumed investment of $\$ 3.4$ billion per year over five years to rural areas.

Source: WRI authors and BW Research. 
Texas, Tennessee, Nevada, and Florida would account for over one-third of rural jobs supported. On a normalized basis (jobs created as a share of total employment), Massachusetts, Nevada, California, Maryland, and Arizona would see the most job gains from federal investment in TDS (Figure 9). Note: For detailed outputs by state, see Appendix D.

\section{Figure 9 | Geographic Distribution of Rural Job Creation from Federal Investments in Transmission, Distribution, and Storage}

Jobs supported in rural counties per 1,000

private sector workers (per year for five years)

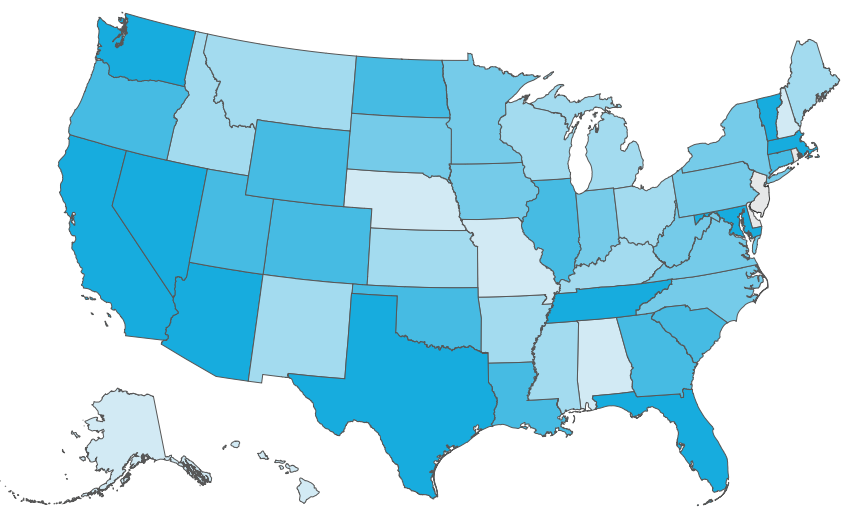

Note: Delaware, the District of Columbia, New Jersey, and Rhode Island do not have any rural counties as defined by the U.S. Department of Agriculture.

Source: WRI authors and BW Research.

\section{The Federal Policy Opportunity}

These economic benefits can be achieved through a combination of targeted tax credits and grant, loan, and loan guarantee programs. These mechanisms can be deployed in tandem to accelerate and unlock private investment for emerging technologies.

Specific policies that together can catalyze needed investments include the following:

Offering tax credits to incentivize transmission projects that are regionally significant and enable renewable energy integration; stand-alone energy storage technologies; and domestic clean energy manufacturing facilities (tax code sec. 48C)

Reauthorizing the Department of Energy's Smart Grid Investment Grant program to promote investments in smart grid technologies
Authorizing the Department of Transportation to make transmission infrastructure projects, especially those that emphasize the integration of renewable energy, eligible under the Transportation Infrastructure Finance and Innovation Act loan guarantee program

- Providing loans and loan guarantees through the USDA Electric Infrastructure Loan \& Loan Guarantee program to help finance transmission and distribution systems in rural areas

- Providing grants and technical assistance to rural electric cooperatives to deploy energy storage and microgrid technologies

While many policies mentioned above would apply to the whole country, some specifically target rural areas. USDA's Electric Program, for instance, provides loans and loan guarantees to maintain, upgrade, and expand rural energy infrastructure, including investments in smart grid technologies that can catalyze broadband services in underserved rural communities. Electric cooperatives, which provide electricity to most rural customers, are one of the main beneficiaries of these federal programs. Federal funding can further help electric cooperatives improve energy grid capacity and resiliency by investing in energy storage and microgrid projects. Moreover, federal investment including tax credits to incentivize the construction of transmission projects should be accompanied with policies that address current challenges around siting, permitting, and allocating costs for new projects.

\subsection{Environmental Remediation of Abandoned Fossill Fuel Infrastructure}

\section{The Issue}

The production and use of fossil fuels have economically powered communities across the United States for generations. At the same time, the mining, drilling, and burning of fossil fuels have exacted an enormous toll on the environment and public health. Abandoned coal mines, where mining-related structures, equipment, and waste have been left behind in disuse and disrepair, exist in many rural parts of the country and adversely impact local ecosystems in addition to emitting methane. Orphaned oil and gas wells-i.e., wells that no longer have a solvent or known owner to pay plugging costs-also emit methane, harming the health of surrounding communities and contributing to climate change. Studies find that orphaned, unplugged wells emit anywhere between 0.03 
to 0.19 metric tons (mt) of methane per well (Raimi et al. 2020), with a corresponding range in total emissions of 64,000 to $404,000 \mathrm{mt}$ for the estimated 2.1 million orphan wells in the United States.

Federal investment in environmental remediation programs can provide near-term job opportunities to clean up polluted sites as well as create additional jobs if those sites are converted to other productive uses such as developing solar energy on former mine lands. In many cases, these sites are in rural communities with ties to oil, gas, and coal production, thus providing opportunities to support communities adversely impacted by declining production. Cleaning up coal mines, for instance, can employ former miners who already have the required skills or can be quickly trained for these positions.

Similarly, there is significant overlap in skills required for plugging wells and those used in oil and gas extraction.
Figure 11 | Geographic Distribution of Rural Job Creation from Federal Investments in Environmental Remediation of Abandoned Fossil Fuel Infrastructure

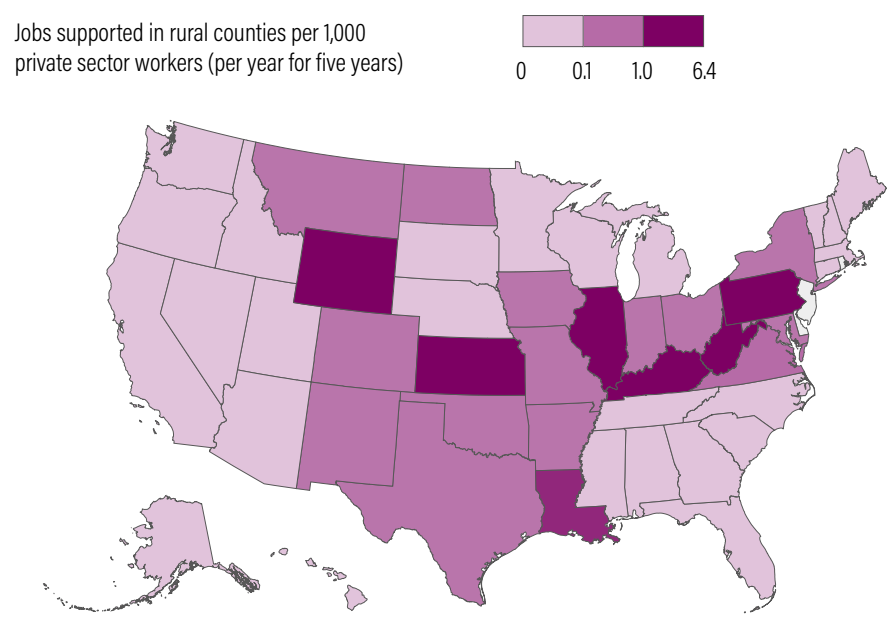

Note: Delaware, the District of Columbia, New Jersey, and Rhode Island do not have any rural counties as defined by the U.S. Department of Agriculture.

Source: WRI authors and BW Research.

\section{Figure 10 | Illustration of Investments in Orphaned 0il and Gas Well Remediation and Associated Benefits for Rural Areas}

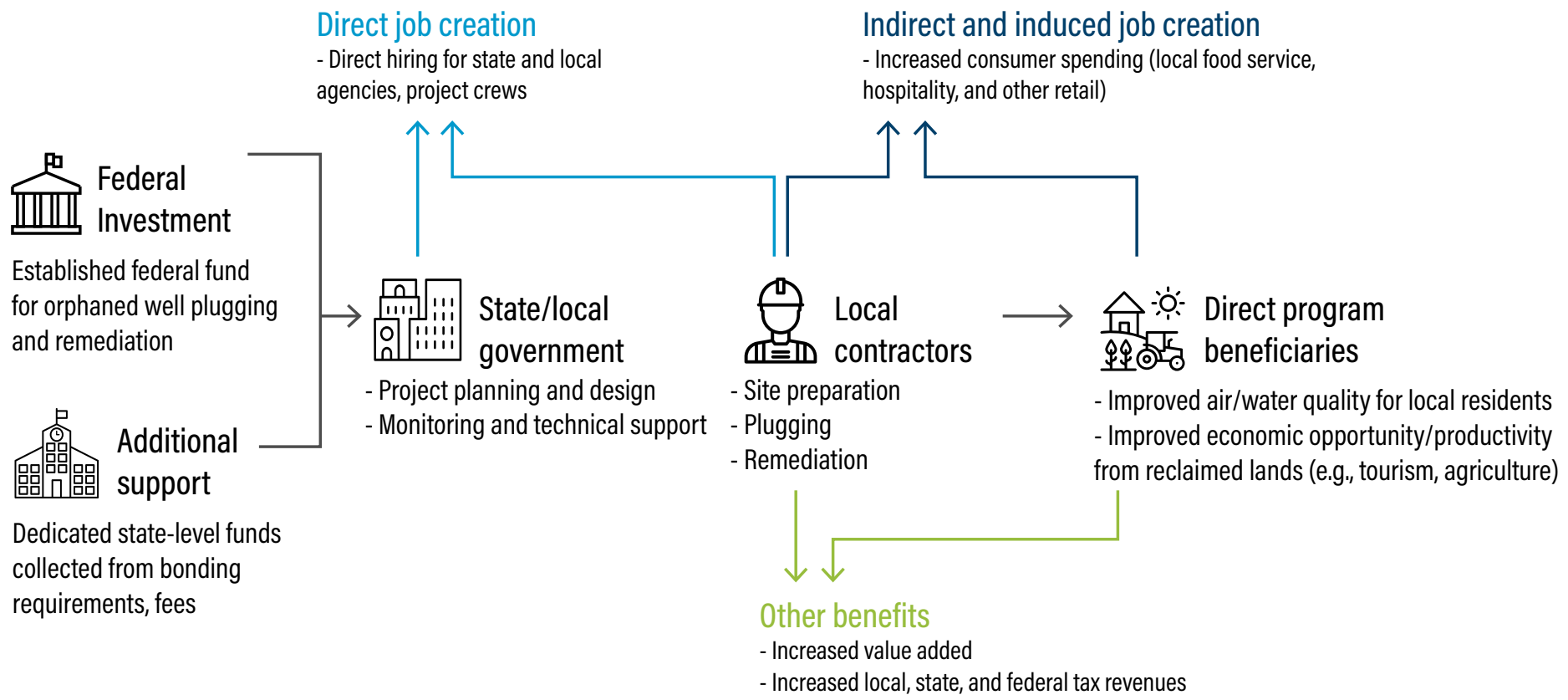



and Coal Mines

\begin{tabular}{|c|c|c|c|c|c|}
\hline & $\begin{array}{l}\text { JOBS PER YEAR FOR } 5 \\
\text { YEARS }\end{array}$ & $\begin{array}{l}\text { VALUE ADDED PER } \\
\text { YEAR FOR } 5 \text { YEARS } \\
\text { (\$, MILLIONS) }\end{array}$ & $\begin{array}{l}\text { EMPLOYEE } \\
\text { COMPENSATION PER } \\
\text { YEAR FOR } 5 \text { YEARS } \\
\text { (\$, MILLIONS) }\end{array}$ & & $\begin{array}{l}\text { TAXES PER YEAR FOR } \\
5 \text { YEARS } \\
\text { (\$, MILLIONS) }\end{array}$ \\
\hline Direct effects & 4,770 & $\$ 921$ & $\$ 411$ & Local & $\$ 36$ \\
\hline Indirect effects & 4,943 & $\$ 615$ & $\$ 316$ & State & $\$ 41$ \\
\hline Induced effects & 4,905 & $\$ 461$ & $\$ 225$ & Federal & $\$ 88$ \\
\hline Total & 14,618 & $\$ 1,997$ & $\$ 952$ & Total & $\$ 165$ \\
\hline
\end{tabular}

Note: Assumed investment of $\$ 1.3$ billion per year over five years to rural areas.

Source: WRI authors and BW Research.

\section{The Rural Economic Opportunity}

This analysis examines the impact of a total federal investment of $\$ 2.4$ billion for plugging and environmental remediation of over 60,000 documented orphaned oil and gas wells and cleaning up over 2,000 abandoned coal mines per year over five years. Of this, $\$ 1.3$ billion would go to rural areas, representing a significant down payment toward creating economic opportunities for fossil fueldependent regions impacted by the transition to a lowcarbon economy. Figure 10 illustrates an example of how such investments can flow to rural areas, generating jobs, value added, and other local or regional benefits.

We estimate that this rural investment would support 14,620 direct, indirect, and induced jobs each year that would last for at least five years (73,100 job-years). The investment would also lead to $\$ 1,997$ million in value added to rural economies each year for five years, including \$952 million in employee compensation and $\$ 164$ million in tax revenues (Table 7). Rural counties in Pennsylvania, Kentucky, Kansas, West Virginia, and Texas would account for nearly three-quarters of jobs supported. On a normalized basis (jobs created as a share of total employment), rural counties in Pennsylvania, Kansas, West Virginia, Kentucky, and Wyoming would benefit the most from federal investment in environmental remediation of orphaned oil and gas wells and abandoned coal mines (Figure 11). Note: For detailed outputs by state, see Appendix E.

\section{The Federal Policy Opportunity}

The federal government has historically played a large role in the cleanup and remediation of polluted sites, especially those located in low-income and minority communities. The following federal investments in environmental remediation of abandoned mines and wells can significantly reduce pollution in rural communities:

Increasing federal funding to clean up abandoned coal mine sites, potentially through the federal Abandoned Mine Land program

- Creating a new federal program to plug and remediate documented orphaned oil and gas well sites

Large-scale remediation programs for orphaned and abandoned sites as envisioned in this report require public funding, in large part because such sites no longer have solvent owners. However, federal investment should be paired with policy reforms that ensure that fossil fuel companies, rather than taxpayers, are responsible for cleaning up polluted sites moving forward. Though states require oil and gas companies to set aside money to plug wells and restore sites once production ends, the amount required from them is nowhere close to the actual plugging and remediation costs (Bordoff et al. 2020). State and federal agencies can collaborate to ensure that bonding requirements and other mechanisms are strengthened. Federal grants to states can also be tied to requirements that states update their regulations to reflect true costs, thereby reducing the risks of creating a new generation of orphaned wells. 
Furthermore, the scale and pace of federal investment should account for the current administrative capacity of state programs to channel federal dollars into remediation projects. To that end, a portion of federal funding could be targeted toward state regulatory agencies, improving their capacity to administer large-scale programs.

Finally, Congress and implementing state agencies can incorporate provisions to ensure that investments are accompanied with strong labor standards, including a prevailing wage guarantee, "local hire" directives, and preference given to laid-off fossil fuel workers in the region. These provisions can heighten the benefits of federal investments in rural communities, which host a disproportionate share of abandoned fossil fuel sites.

\subsection{Tree Restoration on Federal Lands}

The Issue

Federal lands are critical to the economies of many U.S. rural communities: Rural counties in the western United States with large shares of federal land have experienced significantly higher rates of growth in employment, income, and population in recent decades compared with rural counties with smaller shares (Lawson 2017). Federal lands are also critical for emissions mitigation: Federal forests store 63 gigatons of carbon dioxide equivalent (GtCO2e) - an amount that exceeds cumulative U.S. net emissions over the last decade-and more carbon per acre than privately owned forests (Smith et al. 2019).

But federal lands can do even more to contribute to rural economies and carbon removal. Increasing rates of disturbance due to wildfire, pests, and disease have left large areas of federal forest land degraded or barren, sequestering carbon at lower rates than it otherwise could (Domke et al. 2020). Current funding for restoration programs within the U.S. Forest Service (USFS) and other land management agencies is woefully insufficient to meet the need for reforestation and restocking on federal lands, resulting in a growing backlog of projects (Wagner 2014). Disturbed and unhealthy forests also provide inferior opportunities for recreation, causing a drag on neighboring rural economies (Rosenberger et al. 2012; Arnberger et al. 2018).

Figure 12 | ||lustration of Investments in Tree Restoration via the Restoration Trust Fund and Associated Benefits to

\section{Rural Areas}

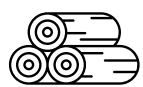

Tariffs on imported

timber and

wood products

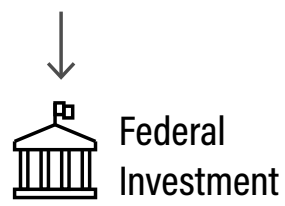

Reforestation Trust Fund

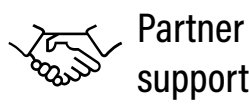

Federal partners

(e.g., National Forest Foundation,

American Forests)
Direct job creation

- Direct hiring by federal agencies, implementing partners, and contractors
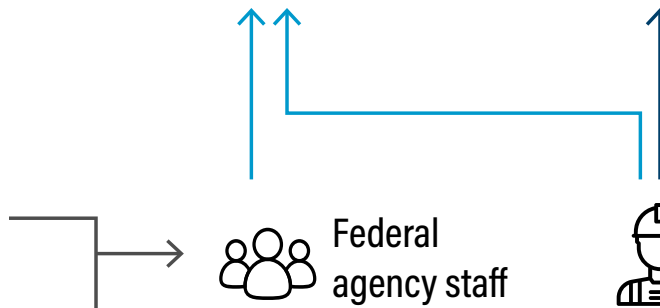

- Project planning and design - Support for site preparation and planting

Indirect and induced job creation

- Increased regional capacity for tree nurseries and seed collection

- Increased consumer spending (e.g., tourism, local food service, hospitality, and retail)

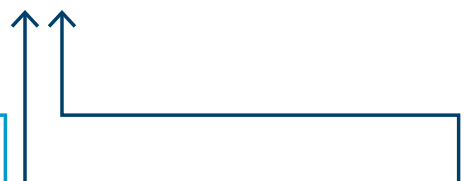

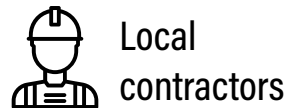

- Site preparation

- Planting crews

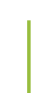

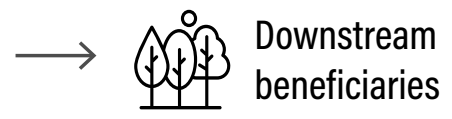

- Recreation on federal lands

- Users of improved environmental services (e.g., water utilities, hunters and anglers, adjacent communities)

Other benefits

- Increased value added to rural economies - Increased tax revenues 


\begin{tabular}{|c|c|c|c|c|c|}
\hline & $\begin{array}{l}\text { JOBS PER YEAR FOR } 20 \\
\text { YEARS }\end{array}$ & $\begin{array}{l}\text { VALUE ADDED PER } \\
\text { YEAR FOR } 20 \text { YEARS (S, } \\
\text { MILLIONS) }\end{array}$ & $\begin{array}{l}\text { EMPLOYEE COMPENSATION } \\
\text { PER YEAR FOR } 20 \text { YEARS (\$, } \\
\text { MILLIONS) }\end{array}$ & & $\begin{array}{l}\text { TAXES ON PRODUCTION } \\
\text { AND IMPORTS PER } \\
\text { YEAR FOR } 20 \text { YEARS (\$, } \\
\text { MILLIONS) }\end{array}$ \\
\hline Direct & 7,000 & $\$ 282$ & $\$ 235$ & Local & $\$ 2$ \\
\hline Indirect & 700 & $\$ 55$ & $\$ 30$ & State & $\$ 3$ \\
\hline Induced & 1,600 & $\$ 137$ & $\$ 65$ & Federal & $\$ 7$ \\
\hline Total & 9,300 & $\$ 474$ & $\$ 330$ & Total & $\$ 12$ \\
\hline
\end{tabular}

Note: Assumed investment of $\$ 350$ million per year over 20 years to rural areas.

Source: WRI authors and BW Research.

Due to overstocking and a subsequently high risk of catastrophic wildfires in many western federal forests, this analysis considers restocking opportunities only in eastern states; however, this analysis does include reforestation opportunities in western states where forests and corresponding carbon stocks have been lost due to fire and pathogens. Eighteen million acres of federal land are suitable for reforestation or restocking (Cook-Patton et al. 2020; USFS 2021; Sohngen 2018). ${ }^{4}$ Collectively, these lands could sequester an additional 17 metric tons of carbon dioxide equivalent (MtCO2e) per year by 2030, and up to $35 \mathrm{MtCO} 2 \mathrm{e}$ per year in 2040 and beyond (CookPatton et al. 2020; Mulligan et al. 2020). ${ }^{5}$

\section{The Rural Economic Opportunity}

Such a wide-scale effort to restore trees on federal lands would require a concerted and sustained national investment. This analysis considers a national investment of $\$ 445$ million annually over 20 years, of which $\$ 350$ million would flow to rural areas (see Appendix K). This investment in rural America would support 9,300 direct, indirect, and induced jobs annually that would last for 20 years (186,00o job-years). These jobs would provide $\$ 474$ million in annual value added to rural economies, including \$330 million in employee compensation and $\$ 12$ million in tax revenues (Table 8). Figure 12 illustrates an example of how such investments would flow to rural areas, generating jobs, value added, and other local or regional benefits.

Over 70 percent of rural jobs would be created in the Intermountain West region, which includes the top five states for job creation. Utah stands to benefit the most, with a total potential of 1,500 jobs each year for 20 years.
On a normalized basis (jobs created as a share of total employment), Utah, Colorado, Wyoming, Idaho, and New Mexico have the highest levels of job creation (Figure 13). Note: For a full table of all state-level impacts, see Appendix G.

Figure 13 | Geographic Distribution of Rural Job Creation from Tree Restoration on Federal Lands

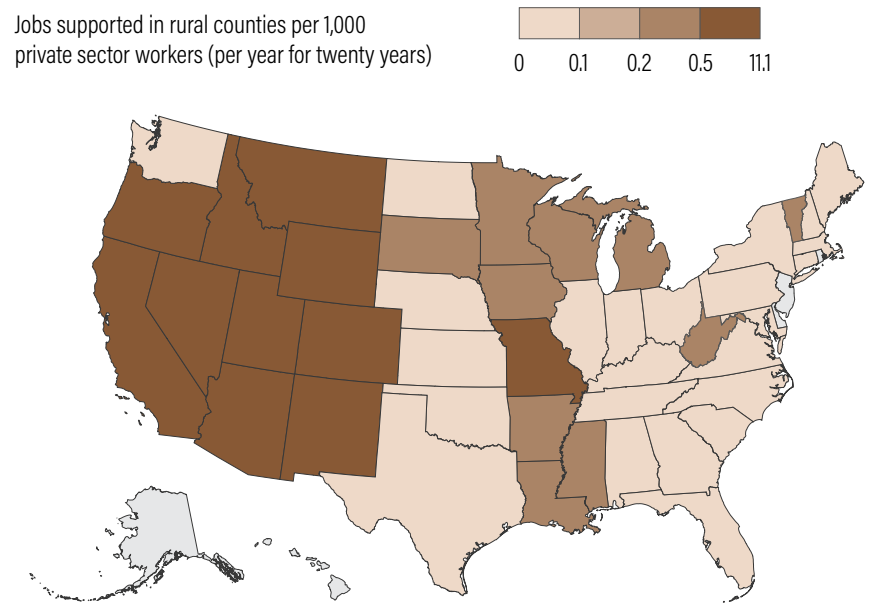

Note: Delaware, the District of Columbia, New Jersey, and Rhode Island do not have any rural counties as defined by the U.S. Department of Agriculture. Alaska and Hawaii were not included in this analysis due to data availability limitations.

Source: WRI authors and BW Research.

\section{The Federal Policy Opportunity}

Congress can provide sufficient funding to federal agencies to accelerate tree restoration on federal lands. Actions that could contribute toward this objective include increasing appropriations for USFS programs that can help restock 
federal forests affected by pests, diseases, or other disturbances, including the Forest Health Monitoring Program, Vegetation and Watershed Management Program, and Collaborative Forest Landscape Restoration Program.

Actions could also include increasing appropriations for programs that support tree restoration on lands managed by other federal agencies, including the Bureau of Land Management (BLM), U.S. Fish and Wildlife Service (USFWS), and Department of Defense. Federal funding can also attract matching funds from state and local governments, civil society, and the private sector, augmenting its benefits for rural economies and climate change. However, funding for federal lands can be deployed only at the rate that federal agencies can design, review, and permit projects. Increasing agency capacity to conduct these project planning activities is therefore critical to scaling up tree restoration on federal lands.

In addition to increased program funding and agency capacity, forest restoration on federal lands will require an expanded workforce to plan, implement, and monitor projects. Developing and training this workforce and ensuring that high-quality, well-paid jobs are created will require additional investment beyond what we consider here. Providing funding for jobs through the proposed Civilian Climate Corps could alleviate this potential labor bottleneck and set standards for job quality.

\subsection{Tree Restoration on Non-federal Lands}

The Issue

Opportunities for tree restoration on non-federal lands cover $\mathbf{2 9 6 . 2}$ million acres and offer the potential to remove $156 \mathrm{MtCO} 2 \mathrm{e}$ per year by 2030, and up to $312 \mathrm{MtCO} 2 \mathrm{e}$ per year in 2040 and beyond-greater than any other near-term strategy for carbon removal (Cook-Patton et al. 2020; Sohngen 2018; USFS 2021; Fargione et al. 2018; Mulligan et al. 2020). ${ }^{6}$ More than two-thirds of the nation's forest area are located on non-federal lands, including land owned by state and local governments and an estimated 11 million private forest landowners (Oswalt et al. 2014). Non-federal forests produce over 90 percent of U.S. timber supply and other forest products while storing $130 \mathrm{GtCO} 2 \mathrm{e}$ (Oswalt et al. 2014; Smith et al. 2019). Those forests are an important economic driver for many rural communities: Private forests contribute over

Figure 14 | IIlustration of Investments in Tree Restoration via USDA Conservation Programs and Associated Benefits to Rural Areas

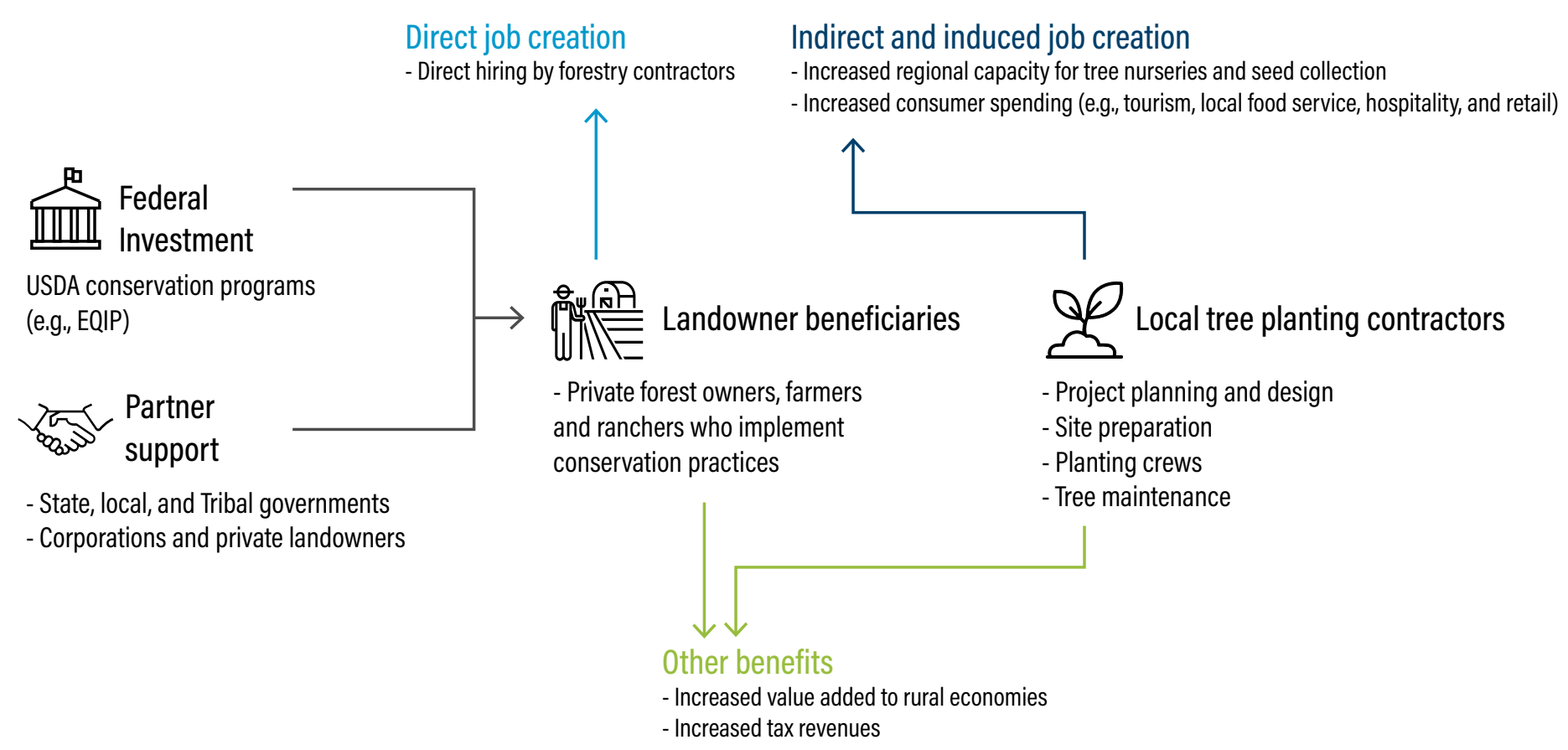


Table 9 | Rural Economic Impacts from Tree Restoration on Non-federal Lands

\begin{tabular}{|l|l|l|l|l|l|}
\hline & $\begin{array}{l}\text { JOBS PER YEAR FOR 20 } \\
\text { YEARS }\end{array}$ & $\begin{array}{l}\text { VALUE ADDED PER } \\
\text { YEAR FOR 20 YEARS (\$, } \\
\text { MILLIONS) }\end{array}$ & $\begin{array}{l}\text { EMPLOYEE COMPENSATION } \\
\text { PER YEAR FOR 20 YEARS (\$, } \\
\text { MILLIONS) }\end{array}$ & $\begin{array}{l}\text { TAXES ON PRODUCTION AND } \\
\text { IMPORTS PER YEAR FOR 20 } \\
\text { YEARS (\$, MILLIONS) }\end{array}$ \\
\hline Direct & 57,300 & $\$ 2,278$ & $\$ 1,917$ & Local & $\$ 34$ \\
\hline Indirect & 4,800 & $\$ 431$ & $\$ 229$ & State & $\$ 44$ \\
\hline Induced & 14,000 & $\$ 1,210$ & $\$ 589$ & Federal & $\$ 134$ \\
\hline Total & $\mathbf{7 6 , 2 0 0}$ & $\mathbf{\$ 3 , 9 1 9}$ & $\mathbf{\$ 2 , 7 3 4}$ & Total & $\mathbf{\$ 2 1 2}$
\end{tabular}

Note: Assumed investment of $\$ 2.8$ billion per year over 20 years to rural areas.

Source: WRI authors and BW Research.

5 percent of national manufacturing GDP (Forest2Market 2019), while recreation and other ecosystem services provide additional economic value.

Even beyond forests, trees can be an important contributor to rural economies. Silvopasture systems can diversify income streams for producers, increase livestock productivity by reducing heat stress, and build land value (Grado and Husak 2004; Mayerfeld et al. 2016). Cropland agroforestry systems generate on-farm income from a secondary crop like timber, fruit, or nuts while benefiting the primary crop by reducing soil erosion and enhancing soil fertility (Schoeneberger et al. 2012).

Restoring trees on private, state, and other non-federal public lands can create new jobs in rural forest and agricultural communities while enhancing the capacity of forests to reduce emissions. Because of the high labor inputs and relatively low capital requirements for tree restoration projects, investments in tree restoration tend to generate more jobs than comparable investments in other economic sectors (Pollin and Chakraborty 2020).

\section{The Rural Economic Opportunity}

This analysis examines a federal investment of $\$ 4.3$ billion per year over 20 years, of which $\$ 2.8$ billion would flow to rural areas. That investment would create 76,200 direct, indirect, and induced jobs that would last for 20 years (a total of 1.5 million job-years), of which 44,000 jobs would be attributable to reforestation and restocking projects and 32,200 would be attributable to silvopasture and cropland agroforestry. This investment would add $\$ 3.9$ billion annually to rural economies, including $\$ 2.7$ billion in employee compensation and \$212 million in tax revenues (Table 9). Figure 14 illustrates an example of how such investments would flow to rural areas, generating jobs, value added, and other local or regional benefits.

Rural jobs created by restoring trees on non-federal lands are concentrated in the Midwest, which would account for more than one in three jobs created. The top five states for rural job creation would be Missouri, Ohio, South Dakota, Michigan, and Wisconsin. On a normalized basis (jobs created as a share of total employment), states with the greatest job creation would include Missouri, South

Figure 15 | Geographic Distribution of Rural Job Creation from Tree Restoration on Non-federal Lands

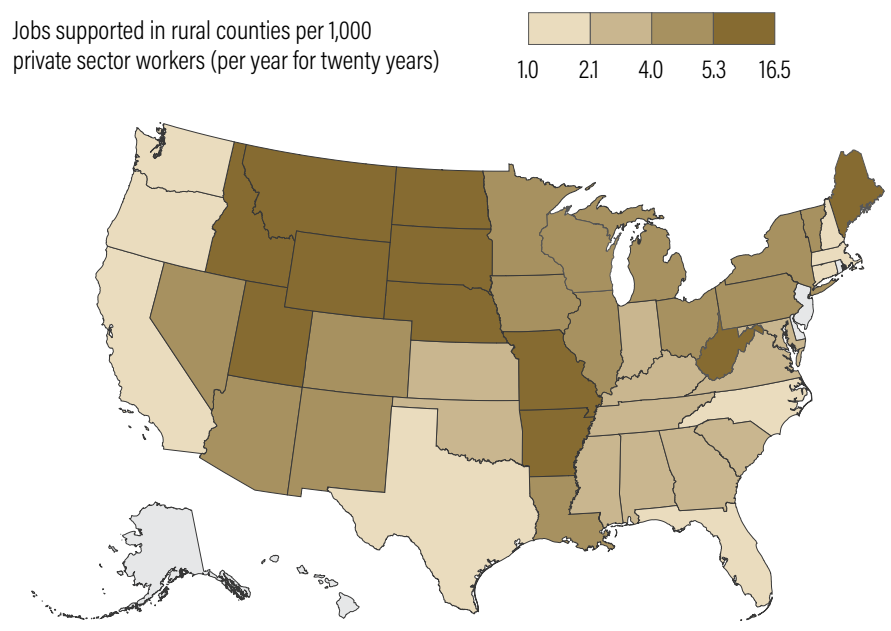

Note: Delaware, the District of Columbia, New Jersey, and Rhode Island do not have any rural counties as defined by the U.S. Department of Agriculture. Alaska and Hawaii were not included in this analysis due to data availability limitations.

Source: WRI authors and BW Research. 
Dakota, North Dakota, Montana, and Maine (Figure 15).

Note: For a full table of state-level economic impacts, see Appendix $H$.

\section{The Federal Policy Opportunity}

Federal incentives for planting and maintaining trees on non-federal lands in ways that are ecologically appropriate, increase forest resiliency, and sequester carbon will be critical to creating rural jobs and realizing economic benefits. A federal incentive program could take the form of a tax credit or landowner payments for tree restoration. While these policy mechanisms target the same objectives, there are important trade-offs in how they would function (see Table 10).

A tax credit approach could be modeled off the existing 45Q tax credit for carbon capture, utilization, and storage, but with a focus on natural carbon capture. Making the tax credit refundable or transferable would facilitate participation by all eligible landowners, regardless of their tax liability.

Direct payments could come through expansion of existing USDA conservation programs such as the Environmental Quality Incentives Program and the Conservation Reserve Program, with additional guidance to prioritize forest restoration projects in application review processes as well as guidance regarding carbon credit allocations.

\section{Table 10 | Characteristics of Incentive Structures for Tree}

\section{Restoration on Non-federal Lands}

\begin{tabular}{|l|l|l|}
\hline Authority & $\begin{array}{l}\text { TAX CREDIT } \\
\text { Requires new } \\
\text { congressional authority }\end{array}$ & $\begin{array}{l}\text { LANDOWNER PAYMENTS } \\
\text { Could use existing } \\
\text { authorities for Farm Bill } \\
\text { conservation programs }\end{array}$ \\
\hline Administration & Treasury Department & USDA \\
\hline Payment rates & $\begin{array}{l}\text { Set in statute, could be } \\
\text { outcome based (per } \\
\text { ton of carbon dioxide } \\
\text { sequestered) }\end{array}$ & $\begin{array}{l}\text { Set by USDA based on } \\
\text { practice costs, land } \\
\text { rental rates, and/or other } \\
\text { factors }\end{array}$ \\
\hline $\begin{array}{l}\text { Distribution of } \\
\text { benefits }\end{array}$ & $\begin{array}{l}\text { May provide greater } \\
\text { benefits to large } \\
\text { landowners due to } \\
\text { their larger tax liability } \\
\text { and capacity to cover } \\
\text { administrative costs }\end{array}$ & $\begin{array}{l}\text { May primarily benefit } \\
\text { smaller landowners due } \\
\text { to income limits for Farm } \\
\text { Bill program eligibility }\end{array}$ \\
\hline
\end{tabular}

Note: USDA = U.S. Department of Agriculture.

Source: WRI authors.
Under either a tax credit or direct payment program, expanding eligibility to third-party intermediaries that contract with landowners to implement tree restoration projects could facilitate scale-up by reducing transaction costs and leveraging private finance (Mulligan et al. 2020).

Additional federal funding would also be needed to accelerate reforestation, restocking, and agroforestry restoration on state- and locally owned lands as well as private lands that cannot take advantage of tax credits or USDA programs. The USFS could funnel additional funding to tree restoration projects through the Forest Stewardship Program, the Forest Health Management Program on Cooperative Lands, and the Urban and Community Forestry Program.

Importantly, the investments and policy levers contemplated here do not include necessary investments upstream in the supply chain for rural tree restoration efforts, such as expanding the national nursery capacity or building and supporting a sufficient workforce to implement tree restoration projects at an accelerated pace and scale. Current legislative proposals to increase funding for federal nurseries and fund the Civilian Climate Corps proposed by President Biden can begin to address these needs. These investments also do not address the need for long-term, ecologically informed forest management to support carbon storage and climate resilience into the future. State- and local-level programs to incentivize and support forest stewardship and maintenance of forest cover will be necessary to complement federal investment.

\subsection{Wildfire Risk Mitigation}

\section{The Issue}

Many forests in the United States, particularly in western states, are facing the risk of large and intense wildfires that threaten ecosystems and communities. Historical wildfire suppression has created unnaturally high tree densities and abundant brushy vegetation that can fuel highseverity fires (Steel et al. 2015). Additionally, the effects of climate change are already increasing fire incidence and intensity as hotter, drier summers become the norm and chronically drought-stressed trees succumb to insect infestations, creating additional fuel for fires (McKenzie et al. 2011; van Mantgem et al. 2013).

In 2020, the USFS and Department of the Interior (DOI) spent $\$ 2.3$ billion fighting wildfires, and this yearly cost is likely to increase as the effects of climate change intensify 
(NIFC 2020). There is evidence, however, that federal investment in prescribed burning and removal of smalldiameter trees could help decrease the size and intensity of wildfires while improving forest health and decreasing fire suppression costs (North et al. 2015; Snider et al. 2006). This investment could also support rural forestry jobs, stimulate rural economies, and decrease fire risk for communities living adjacent to forests.

Prescribed burning and biomass removal could also offer climate benefits by reducing the risk of high-intensity fires that contribute to emissions and decrease forest carbon storage. Prescribed burning alone could reduce wildfire carbon emissions in the western United States by 18-25 percent and could increase long-term forest carbon storage by $18 \mathrm{MtCO}_{2}$ per year through avoided tree mortality (Fargione et al. 2018; Wiedinmyer and Hurteau 2010).

There are 57.4 million acres of forest considered to be at a high or very high risk of wildfire in the United States, of which 33.2 million acres are found in rural counties (Dillon and Gilbertson-Day 2020). Deploying landscapescale strategies to reduce wildfire risk can be resource- and time-intensive and requires participation from many stakeholders. Federal investment and policy support are required to employ these treatments at scale.

\section{The Rural Economic Opportunity}

This analysis contemplates a federal investment of $\$ 1.5$ billion per year over 20 years, which would support prescribed burning and small-diameter tree thinning in federal, state, and private forests at high risk for wildfire. Over 70 percent of this investment, or $\$ 1.1$ billion, would flow to rural counties. This investment, plus the downstream economic impact of generating products from small-diameter trees, would create 49,000 direct, indirect, and induced rural jobs that would last for 20 years (a total of 980,000 job-years). This would result in $\$ 3.3$ billion in value added to rural economies, including $\$ 2.5$ billion per year in employee compensation and $\$ 183$ million in tax revenues (Table 11). Figure 16 illustrates an example of how such investments would flow to rural areas, generating jobs, value added, and other local or regional benefits.

Figure 16 | IIlustration of Investment in Wildfire Risk Management and Associated Benefits to Rural Areas

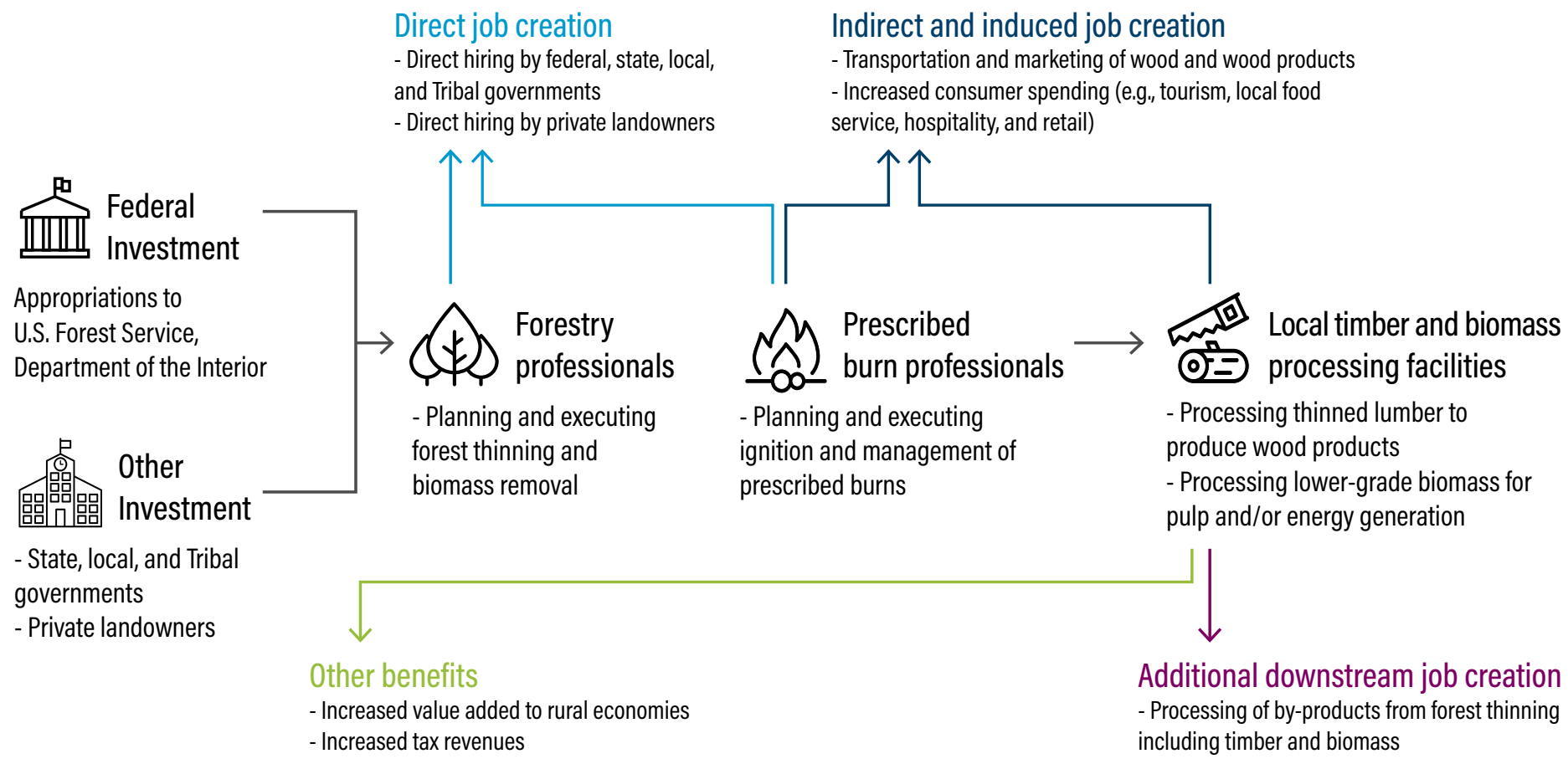

Note: USDA = U.S. Department of Agriculture; EQIP = Environmental Quality Incentives Program; CRP = Conservation Reserve Program. 
Table 11 | Rural Economic Impacts from Wildfire Risk Management

\begin{tabular}{l|l|l|l|l|l|} 
& JOBS & $\begin{array}{l}\text { VALUE ADDED } \\
\text { (\$, MILLIONS) }\end{array}$ & $\begin{array}{l}\text { EMPLOYEE } \\
\text { COMPENSATION } \\
\text { (\$, MILLIONS) }\end{array}$ & $\begin{array}{l}\text { TAXES ON PRODUCTION } \\
\text { AND IMPORTS } \\
\text { (S, MLLIONS) }\end{array}$ \\
\hline Direct effects & 27,000 & $\$ 1,345$ & $\$ 1,540$ & Local & $\$ 29$ \\
\hline Indirect effects & 13,300 & $\$ 1,096$ & $\$ 373$ & State & $\$ 38$ \\
Induced effects & 8,700 & $\$ 816$ & $\$ 587$ & Federal & $\$ 116$ \\
\hline Total & $\mathbf{4 9 , 0 0 0}$ & $\$ \mathbf{3}, 257$ & $\mathbf{\$ 2 , 5 0 0}$ & Total & $\mathbf{\$ 1 8 3}$
\end{tabular}

Note: Assumed investment of $\$ 1.1$ billion per year over 20 years to rural areas.

Source: WRI authors and BW Research.

The majority of rural jobs created by federal investment in fuel load reduction occur in the western United States. The top five states for rural job creation (California, New Mexico, Wyoming, Idaho, and Oregon) account for more than 75 percent of all yearly job creation potential for the conterminous United States. California alone offers 25 percent of the job creation opportunity. On a normalized basis (jobs created as a share of total employment), states with the highest levels of job creation include California, New Mexico, Wyoming, Idaho, and Oregon (Figure 17). Note: For a full table of state-level impacts, see Appendix I.

Figure 17 | Geographic Distribution of Rural Job Creation from Wildfire Risk Management

Jobs supported in rural counties per 1,000 private sector workers (per year for twenty years)
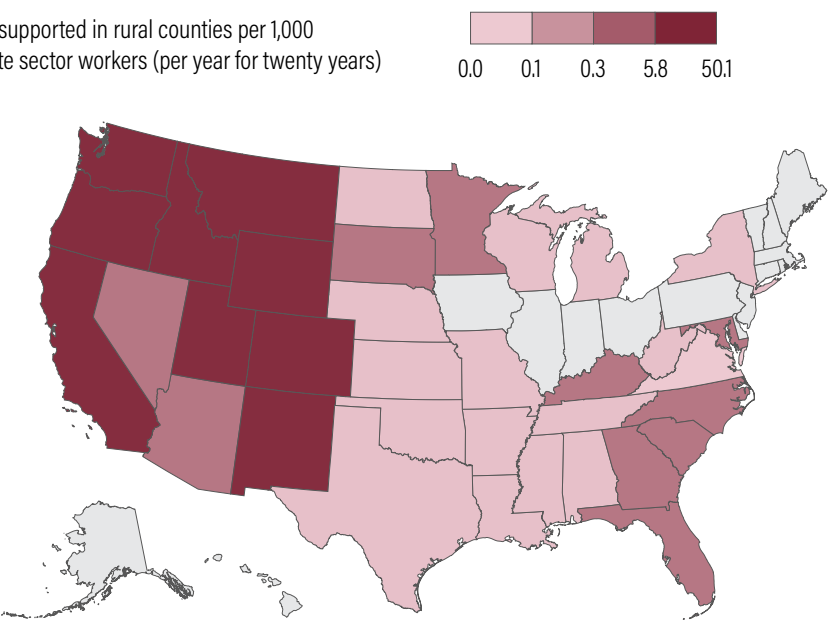

Note: Delaware, the District of Columbia, New Jersey, and Rhode Island do not have any rural counties as defined by the U.S. Department of Agriculture. Alaska and Hawaii were not included in this analysis due to data availability limitations. Based on this analysis, Illinois, Indiana, lowa, Maine, Massachusetts, New Hampshire, Ohio, Pennsylvania, and Vermont do not have high fire risk forest land that is eligible for wildfire risk management treatment.

Source: WRI authors and BW Research.

\section{The Federal Policy Opportunity}

Meeting the need for large-scale fuel load reduction in U.S. forests will require federal investment in policy vehicles that help build long-term forest resilience while stimulating rural economies. To address underfunding for fuel treatment in federal agencies, Congress could increase funding to the USFS "Hazardous Fuels" budget and the DOI Office of Wildland Fire, which allots fuel management funds to the BLM, USFWS, National Park Service, and Bureau of Indian Affairs. An increase in program funding

\section{Box 5 | New Mexico Collaborative Fire Risk Management}

The Forest Stewards Guild (FSG) is a national organization focused on community-building and improved forest management. The Southwest branch hosts more than 20 youth conservation crews that prepare high schoolers and recent graduates to work in the forest industry. They work closely with business, state, and federal partners to address barriers and implement post-wildfire reforestation and pre-wildfire management measures.

In 2016, the FSG and other partners were awarded $\$ 360,000$ in matched funding through the USFS Collaborative Forest Restoration Program enabling a youth conservation crew and state and local partners to implement forest restoration and fire risk management treatments on 288 acres in New Mexico's Rio Grande del Norte National Monument. ${ }^{a}$ The process of strategic thinning and prescribed fires is a common fire risk management practice for the area, with tree removal garnering variable value in bioenergy, architecture, and heating technologies. Through this project, fuel removal and forest restoration directly employed 14 workers in full-time restoration jobs and provided job training experience for 28 local youth.

Notes:

a. FSG 2019

b. FSG 2019, 
for the USFS State and Private Forestry division could also help accelerate fuel load reduction projects in non-federal forests. The USFS Collaborative Forest Landscape Restoration Program (CFLRP), for example, uses publicprivate partnerships to address fire risk and forest health at scale, but its yearly appropriations are mostly devoted to existing projects. CFLRP's appropriations could be increased to support the development of new projects in areas in vital need of fuel load treatment. For an example of fuel treatment projects using existing federal funding, see Box 5 .

Beyond the scope of existing federal programs, new policies could improve the longevity and effectiveness of fire risk mitigation initiatives while supporting community resiliency, innovation, and economic activity. Most USFS fuel treatment projects currently rely on yearly appropriations and, as a result, project terms are too short to make necessary impact and contractors cannot rely on ongoing funding. Improving mechanisms for financing federal fuel treatment, such as amending the USFS's budgetary authority to allow for longer-term contracts and greater leveraging of private investment, would help build capacity to address wildfire risk at scale. Longer-term project funding would also help create fire risk management jobs that would have longer durations, which in turn could support the development and training of professionals specializing in biomass removal and prescribed burning. Even with increased investment in the programs described above, federal fuel treatment projects will require support from private finance and additional staff capacity through partnerships and contracting with state, nonprofit, and private entities.

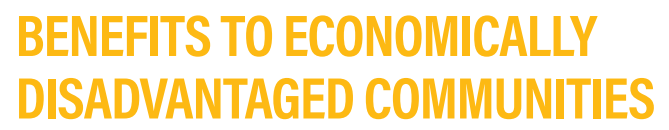

Federal investment in the seven areas of the new climate economy could help create employment and increase economic activity in economically disadvantaged rural counties, helping to revitalize these areas while providing climate benefits. About 52 percent of all rural counties are economically disadvantaged, defined as "at risk" and "distressed" counties by the Economic Innovation Group's DCI. In 2019, these economically disadvantaged rural counties accounted for 43 percent of all rural county employment.

The new climate economy opportunities described here could create over 118 , ooo jobs per year in these counties, resulting in over $\$ 9.8$ billion added to these rural economies annually, including $\$ 5.9$ billion in

Table 12 | Annual Economic Benefits for Economically Disadvantaged Rural Counties

\begin{tabular}{|c|c|c|c|c|}
\hline INVESTMENT AREAS & JOBS CREATED & $\begin{array}{l}\text { VALUE ADDED (\$, } \\
\text { MILLIONS) }\end{array}$ & $\begin{array}{l}\text { EMPLOYEE } \\
\text { COMPENSATION (\$, } \\
\text { MILLIONS) }\end{array}$ & $\begin{array}{l}\text { COMBINED STATE, } \\
\text { FEDERAL, AND LOCAL TAX } \\
\text { REVENUE (\$, MILLIONS) }\end{array}$ \\
\hline Renewable energy & 12,700 & $\$ 1,416$ & $\$ 68,344$ & $\$ 216$ \\
\hline Energy efficiency & 10,800 & $\$ 1,046$ & $\$ 575$ & $\$ 5$ \\
\hline Transmission, distribution, and storage & 20,300 & $\$ 2,370$ & $\$ 1,278$ & $\$ 149$ \\
\hline Remediation of abandoned fossil fuel sites & 9,800 & $\$ 1,341$ & $\$ 638$ & $\$ 109$ \\
\hline Tree restoration on federal lands & 3700 & $\$ 188$ & $\$ 133$ & $\$ 5$ \\
\hline Tree restoration on non-federal lands & 37,100 & $\$ 1,885$ & $\$ 1,345$ & $\$ 102$ \\
\hline $\begin{array}{l}\text { Wildfire risk management including } \\
\text { downstream impacts }\end{array}$ & 24,000 & $\$ 1,640$ & $\$ 1,267$ & $\$ 96$ \\
\hline All investment areas & 118,500 & $\$ 9,888$ & $\$ 5,920$ & $\$ 685$ \\
\hline
\end{tabular}


employee compensation and $\$ 685$ million in total tax revenues (Table 12). Economically disadvantaged rural counties in California, Texas, New Mexico, Missouri, and Kentucky stand to benefit the most in terms of total jobs supported by federal investment in the seven focus areas of this analysis. While this job creation is significant, representing approximately 45 percent of job creation potential from investment in the seven areas of the new climate economy, more needs to be done to ensure economic benefits reach the areas where they are most needed.

The investment in the policies and opportunities modeled in this analysis represent only the first steps toward creating economic opportunities in economically disadvantaged rural counties. As suggested by the White House Environmental Justice Advisory Council (WHEJAC 2021), federal policies and initiatives will need to include measures specifically designed to ensure that investments and benefits reach these disadvantaged communities. This could include workforce training programs in the energy and land sectors with employment guarantees, measures to make clean energy affordable for low-income households, grant programs to support local businesses and nonprofit organizations, and requirements that new program designs be collaborative, inclusive, and accessible to all workers.

\section{CONCLUSION}

The U.S. pathway to a low-carbon future has gained significant momentum as the Biden administration and Congress resume work toward ambitious climate goals. This analysis shows that rural America stands to benefit significantly from federal investment in seven key areas of the new climate economy. Of a total of $\$ 55$ billion in annual federal investment in the new climate economy, an estimated $\$ 14.9$ billion flowing specifically to rural communities would create the following:

Nearly 260,000 rural jobs that would last for at least five years (a total of 1.3 million job-years), spread across every region of the country

- \$21.7 billion per year in value added to rural economies, including $\$ 12.9$ billion in employee compensation and $\$ 1.6$ billion in local, state, and federal tax revenues

118,500 rural jobs annually and added value of $\$ 9.8$ billion per year specifically in economically disadvantaged communities
Approximately 17.5 jobs and $\$ 1.5$ million in value added in rural counties for every $\$ 1$ million in federal investment

For the new climate economy to support economic growth and vitality across the United States, federal policymakers will need to ensure that national climate policies address the needs and priorities of rural communities as well as urban ones. These decisions will ultimately determine how fast clean industries grow and the extent to which the resulting economic benefits are well distributed. Federal policy proposals highlighted in our analysis provide a roadmap that can facilitate the development of thriving rural economies.

Our analysis focuses only on direct economic impacts, but these benefits will be further amplified by reductions in emissions that damage people's health and contribute to climate change. Further research on the economic benefits of investments in the new climate economy in areas not covered in this paper-including electric vehicle manufacturing and infrastructure development, carbon removal infrastructure like carbon dioxide pipelines and geologic storage wells, and technologies to reduce greenhouse gas emissions from agricultural operationscould paint a more comprehensive picture of potential benefits accruing to rural America. Finally, deeper analysis of how federal policies can specifically target underserved rural communities and communities and workers of color is needed.

The new climate economy can help bridge the rural-urban divide by bringing economic opportunities to regions and communities eager for jobs and economic growth while helping the nation meet the ambitious decarbonization goals that can help unlock a prosperous future for all. 


\section{APPENDIX A: TOTAL STATE-LEVEL ECONOMIC INVESTMENT IMPACTS, ALL PATHWAYS}

Table A1 provides the sum of economic outputs from all rural investments including for energy, mines and wells, and the land sector. The total values include the direct, indirect, and induced impacts on jobs, employee compensation, value added, and taxes on production and imports. These impacts are interpreted as impacts per year for the first five years. The "rural impact case" refers to our assumption for the energy sector that 15 percent of federal investment is targeted at rural counties.

Table A1 | Rural Economic Impact, All Pathways

\begin{tabular}{|c|c|c|c|c|c|c|c|}
\hline $\begin{array}{l}\text { AVERAGE IMPACTS } \\
\text { PER YEAR FOR } 5 \text { YEARS } \\
\text { RURAL IMPACT CASE }\end{array}$ & $\begin{array}{l}\text { TOTAL } \\
\text { JOBS PER } \\
\text { YEAR }\end{array}$ & $\begin{array}{l}\text { DIRECT } \\
\text { JOBS PER } \\
\text { YEAR }\end{array}$ & $\begin{array}{l}\text { INDIRECT } \\
\text { JOBS PER } \\
\text { YEAR }\end{array}$ & $\begin{array}{l}\text { INDUCED } \\
\text { JOBS PER } \\
\text { YEAR }\end{array}$ & $\begin{array}{l}\text { TOTAL VALUE } \\
\text { ADDED (GDP) PER } \\
\text { YEAR (\$, MILLIONS) }\end{array}$ & $\begin{array}{l}\text { TOTAL TAXES ON } \\
\text { PRODUCTION AND } \\
\text { IMPORTS (TOPI) PER } \\
\text { YEAR (S, MILLIONS) }\end{array}$ & $\begin{array}{l}\text { TOTAL EMPLOYEE } \\
\text { COMPENSATION } \\
\text { (EMPLOYEE INCOME) } \\
\text { PER YEAR (S, MILLIONS) }\end{array}$ \\
\hline Alabama & 2,619 & 1,555 & 462 & 603 & $\$ 202.8$ & $\$ 12.8$ & $\$ 119.2$ \\
\hline Alaska & 307 & 158 & 68 & 82 & $\$ 37.1$ & $\$ 1.8$ & $\$ 19.5$ \\
\hline Arizona & 2,303 & 1,131 & 535 & 636 & $\$ 208.6$ & $\$ 16.7$ & $\$ 125.2$ \\
\hline Arkansas & 3,572 & 2,361 & 509 & 702 & $\$ 234.6$ & $\$ 19.5$ & $\$ 145.8$ \\
\hline California & 26,689 & 12,623 & 7,163 & 6,902 & $\$ 2,977.7$ & $\$ 211.5$ & $\$ 1,895.6$ \\
\hline Colorado & 8,403 & 4,664 & 1,801 & 1,938 & $\$ 610.0$ & $\$ 46.0$ & $\$ 396.9$ \\
\hline Connecticut & 612 & 311 & 138 & 163 & $\$ 67.4$ & $\$ 5.2$ & $\$ 34.9$ \\
\hline Delaware $^{\mathrm{a}}$ & 0 & 0 & 0 & 0 & $\$ 0.0$ & $\$ 0.0$ & $\$ 0.0$ \\
\hline District of Columbia & 0 & 0 & 0 & 0 & $\$ 0.0$ & $\$ 0.0$ & $\$ 0.0$ \\
\hline Florida & 4,720 & 2,159 & 1,179 & 1,382 & $\$ 460.2$ & $\$ 41.3$ & $\$ 244.6$ \\
\hline Georgia & 4,531 & 2,416 & 970 & 1,146 & $\$ 408.7$ & $\$ 25.5$ & $\$ 235.5$ \\
\hline Hawaii & 546 & 258 & 127 & 162 & $\$ 63.3$ & $\$ 6.3$ & $\$ 31.5$ \\
\hline Idaho & 6,821 & 3,981 & 1,471 & 1,369 & $\$ 455.5$ & $\$ 25.2$ & $\$ 309.4$ \\
\hline Illinois & 7,178 & 3,500 & 1,438 & 2,240 & $\$ 762.1$ & $\$ 69.9$ & $\$ 413.9$ \\
\hline Indiana & 5,292 & 2,705 & 990 & 1,597 & $\$ 446.7$ & $\$ 42.1$ & $\$ 237.0$ \\
\hline lowa & 5,873 & 3,390 & 932 & 1,551 & $\$ 452.4$ & $\$ 44.6$ & $\$ 243.4$ \\
\hline Kansas & 5,049 & 2,352 & 1,336 & 1,361 & $\$ 475.4$ & $\$ 47.4$ & $\$ 247.4$ \\
\hline Kentucky & 6,679 & 3,591 & 1,640 & 1,448 & $\$ 556.3$ & $\$ 51.0$ & $\$ 324.9$ \\
\hline Louisiana & 2,639 & 1,596 & 472 & 570 & $\$ 191.1$ & $\$ 14.6$ & $\$ 121.1$ \\
\hline Maine & 3,290 & 2,090 & 502 & 698 & $\$ 167.9$ & $\$ 16.8$ & $\$ 114.4$ \\
\hline Maryland & 1,441 & 746 & 312 & 383 & $\$ 157.8$ & $\$ 13.1$ & $\$ 84.4$ \\
\hline Massachusetts & 2,952 & 1,288 & 665 & 999 & $\$ 384.4$ & $\$ 24.2$ & $\$ 220.5$ \\
\hline Michigan & 6,909 & 3,917 & 1,174 & 1,818 & $\$ 533.8$ & $\$ 37.5$ & $\$ 330.6$ \\
\hline Minnesota & 5,778 & 3,280 & 1,016 & 1,483 & $\$ 467.6$ & $\$ 32.4$ & $\$ 282.3$ \\
\hline
\end{tabular}


Table A1 | Rural Economic Impact, All Pathways (Cont.)

\begin{tabular}{|c|c|c|c|c|c|c|c|}
\hline $\begin{array}{l}\text { AVERAGE IMPACTS } \\
\text { PER YEAR FOR } 5 \text { YEARS } \\
\text { RURAL IMPACT CASE }\end{array}$ & $\begin{array}{l}\text { TOTAL } \\
\text { JOBS PER } \\
\text { YEAR }\end{array}$ & $\begin{array}{l}\text { DIRECT } \\
\text { JOBS PER } \\
\text { YEAR }\end{array}$ & $\begin{array}{l}\text { INDIRECT } \\
\text { JOBS PER } \\
\text { YEAR }\end{array}$ & $\begin{array}{l}\text { INDUCED } \\
\text { JOBS PER } \\
\text { YEAR }\end{array}$ & $\begin{array}{l}\text { TOTAL VALUE } \\
\text { ADDED (GDP) PER } \\
\text { YEAR (S, MILLIONS) }\end{array}$ & $\begin{array}{l}\text { TOTAL TAXES ON } \\
\text { PRODUCTION AND } \\
\text { IMPORTS (TOPI) PER } \\
\text { YEAR (S, MILLIONS) }\end{array}$ & $\begin{array}{l}\text { TOTAL EMPLOYEE } \\
\text { COMPENSATION } \\
\text { (EMPLOYEE INCOME) } \\
\text { PER YEAR (S, MILLIONS) }\end{array}$ \\
\hline Mississippi & 4,159 & 2,633 & 759 & 767 & $\$ 255.6$ & $\$ 19.5$ & $\$ 158.9$ \\
\hline Missouri & 10,623 & 7,370 & 1,074 & 2,179 & $\$ 615.3$ & $\$ 36.0$ & $\$ 394.1$ \\
\hline Montana & 8,338 & 5,268 & 1,515 & 1,556 & $\$ 482.4$ & $\$ 21.9$ & $\$ 326.3$ \\
\hline Nebraska & 4,131 & 2,758 & 520 & 853 & $\$ 265.8$ & $\$ 18.6$ & $\$ 168.0$ \\
\hline Nevada & 4,501 & 2,581 & 1,005 & 916 & $\$ 418.6$ & $\$ 34.7$ & $\$ 244.0$ \\
\hline New Hampshire & 1,626 & 794 & 348 & 483 & $\$ 136.9$ & $\$ 13.5$ & $\$ 75.6$ \\
\hline New Jersey ${ }^{a}$ & 0 & 0 & 0 & 0 & $\$ 0.0$ & $\$ 0.0$ & $\$ 0.0$ \\
\hline New Mexico & 12,456 & 7,668 & 2,835 & 1,953 & $\$ 677.2$ & $\$ 42.9$ & $\$ 466.2$ \\
\hline New York & 5,097 & 2,974 & 807 & 1,317 & $\$ 508.7$ & $\$ 42.1$ & $\$ 297.4$ \\
\hline North Carolina & 5,091 & 2,535 & 1,327 & 1,228 & $\$ 475.3$ & $\$ 30.2$ & $\$ 268.5$ \\
\hline North Dakota & 3,438 & 2,130 & 425 & 883 & $\$ 260.4$ & $\$ 23.4$ & $\$ 158.0$ \\
\hline Ohio & 8,672 & 4,895 & 1,405 & 2,372 & $\$ 667.0$ & $\$ 46.8$ & $\$ 374.4$ \\
\hline Oklahoma & 3,539 & 1,906 & 774 & 859 & $\$ 268.1$ & $\$ 22.1$ & $\$ 147.6$ \\
\hline Oregon & 6,252 & 3,161 & 1,613 & 1,477 & $\$ 508.9$ & $\$ 31.9$ & $\$ 349.6$ \\
\hline Pennsylvania & 7,759 & 3,952 & 1,558 & 2,249 & $\$ 802.8$ & $\$ 57.2$ & $\$ 411.6$ \\
\hline Rhode Island ${ }^{a}$ & 0 & 0 & 0 & 0 & $\$ 0.0$ & $\$ 0.0$ & $\$ 0.0$ \\
\hline South Carolina & 1,818 & 975 & 403 & 440 & $\$ 152.1$ & $\$ 13.1$ & $\$ 83.7$ \\
\hline South Dakota & 4,926 & 3,355 & 505 & 1,066 & $\$ 277.0$ & $\$ 28.8$ & $\$ 160.6$ \\
\hline Tennessee & 5,966 & 3,213 & 1,403 & 1,350 & $\$ 493.7$ & $\$ 35.6$ & $\$ 273.7$ \\
\hline Texas & 12,361 & 5,301 & 2,972 & 4,089 & $\$ 1,286.3$ & $\$ 122.4$ & $\$ 692.8$ \\
\hline Utah & 4,114 & 2,755 & 641 & 717 & $\$ 234.1$ & $\$ 13.6$ & $\$ 156.4$ \\
\hline Vermont & 3,072 & 1,740 & 617 & 716 & $\$ 207.7$ & $\$ 19.2$ & $\$ 126.4$ \\
\hline Virginia & 3,027 & 1,742 & 576 & 709 & $\$ 282.3$ & $\$ 20.8$ & $\$ 161.5$ \\
\hline Washington & 3,716 & 1,886 & 883 & 946 & $\$ 399.8$ & $\$ 35.8$ & $\$ 242.9$ \\
\hline West Virginia & 3,796 & 2,298 & 633 & 865 & $\$ 334.3$ & $\$ 35.0$ & $\$ 180.7$ \\
\hline Wisconsin & 5,955 & 3,450 & 978 & 1,526 & $\$ 468.6$ & $\$ 31.5$ & $\$ 279.3$ \\
\hline Wyoming & 9,059 & 5,479 & 2,001 & 1,580 & $\$ 558.0$ & $\$ 29.7$ & $\$ 367.6$ \\
\hline
\end{tabular}

Notes: GDP = gross domestic product.a. Delaware, the District of Columbia, New Jersey, and Rhode Island do not have any rural counties as defined by the U.S. Department of Agriculture. Source: BW Research. 
Table A2 provides the sum of economic outputs from all national investments in energy, mines and wells, and the land sector. The total values include the direct, indirect, and induced impacts on jobs, employee compensation, value added, and taxes on production and imports. These impacts are interpreted as impacts per year for the first five years

Table A2 | National Economic Impacts, All Pathways

\begin{tabular}{|c|c|c|c|c|c|c|c|}
\hline $\begin{array}{l}\text { AVERAGE IMPACTS } \\
\text { PER YEAR FOR } 5 \text { YEARS } \\
\text { NATIONAL }\end{array}$ & $\begin{array}{l}\text { TOTAL } \\
\text { JOBS PER } \\
\text { YEAR }\end{array}$ & $\begin{array}{l}\text { DIRECT } \\
\text { JOBS PER } \\
\text { YEAR }\end{array}$ & $\begin{array}{l}\text { INDIRECT } \\
\text { JOBS PER } \\
\text { YEAR }\end{array}$ & $\begin{array}{l}\text { INDUCED } \\
\text { JOBS PER } \\
\text { YEAR }\end{array}$ & $\begin{array}{l}\text { TOTAL VALUE } \\
\text { ADDED (GDP) PER } \\
\text { YEAR (S, MILLIONS) }\end{array}$ & $\begin{array}{l}\text { TOTAL TAXES ON } \\
\text { PRODUCTION AND } \\
\text { IMPORTS (TOPI) PER } \\
\text { YEAR (S, MILLIONS) }\end{array}$ & $\begin{array}{l}\text { TOTAL EMPLOYEE } \\
\text { COMPENSATION } \\
\text { (EMPLOYEE INCOME) } \\
\text { PER YEAR (S, MILLIONS) }\end{array}$ \\
\hline Alabama & 8,980 & 4,762 & 1,943 & 2,274 & $\$ 756.6$ & $\$ 60.3$ & $\$ 423.6$ \\
\hline Alaska & 881 & 453 & 188 & 240 & $\$ 100.4$ & $\$ 5.5$ & $\$ 56.0$ \\
\hline Arizona & 10,910 & 4,928 & 2,745 & 3,237 & $\$ 1,056.8$ & $\$ 92.5$ & $\$ 588.7$ \\
\hline Arkansas & 6,501 & 3,992 & 1,099 & 1,410 & $\$ 444.2$ & $\$ 44.1$ & $\$ 262.6$ \\
\hline California & 102,349 & 44,982 & 27,058 & 30,309 & $\$ 12,874.7$ & $\$ 1,003.1$ & $\$ 7,165.6$ \\
\hline Colorado & 22,132 & 10,161 & 5,094 & 6,877 & $\$ 1,958.4$ & $\$ 208.4$ & $\$ 1,127.9$ \\
\hline Connecticut & 3,426 & 1,735 & 768 & 922 & $\$ 367.0$ & $\$ 30.6$ & $\$ 187.4$ \\
\hline Delaware & 1,097 & 625 & 214 & 258 & $\$ 101.3$ & $\$ 6.3$ & $\$ 56.5$ \\
\hline District of Columbia & 1,021 & 587 & 189 & 246 & $\$ 115.7$ & $\$ 11.0$ & $\$ 73.2$ \\
\hline Florida & 26,413 & 11,408 & 7,001 & 8,004 & $\$ 2,615.7$ & $\$ 250.3$ & $\$ 1,334.5$ \\
\hline Georgia & 16,505 & 7,887 & 4,114 & 4,505 & $\$ 1,647.7$ & $\$ 109.8$ & $\$ 890.0$ \\
\hline Hawaii & 2,114 & 990 & 465 & 659 & $\$ 234.1$ & $\$ 26.2$ & $\$ 114.9$ \\
\hline Idaho & 10,426 & 5,825 & 2,293 & 2,308 & $\$ 736.6$ & $\$ 50.7$ & $\$ 463.4$ \\
\hline Illinois & 25,217 & 10,735 & 5,688 & 8,795 & $\$ 2,829.0$ & $\$ 296.3$ & $\$ 1,496.4$ \\
\hline Indiana & 18,072 & 8,412 & 3,679 & 5,981 & $\$ 1,556.1$ & $\$ 183.3$ & $\$ 822.4$ \\
\hline lowa & 10,929 & 5,748 & 1,939 & 3,243 & $\$ 866.1$ & $\$ 105.8$ & $\$ 455.9$ \\
\hline Kansas & 8,834 & 4,052 & 2,198 & 2,584 & $\$ 803.9$ & $\$ 91.7$ & $\$ 414.2$ \\
\hline Kentucky & 10,756 & 5,740 & 2,666 & 2,350 & $\$ 892.0$ & $\$ 77.8$ & $\$ 517.4$ \\
\hline Louisiana & 8,325 & 4,534 & 1,822 & 1,968 & $\$ 675.7$ & $\$ 55.0$ & $\$ 399.8$ \\
\hline Maine & 5,678 & 3,280 & 973 & 1,425 & $\$ 326.1$ & $\$ 40.6$ & $\$ 203.2$ \\
\hline Maryland & 8,766 & 4,526 & 1,895 & 2,345 & $\$ 931.0$ & $\$ 81.1$ & $\$ 492.9$ \\
\hline Massachusetts & 19,562 & 8,656 & 4,370 & 6,536 & $\$ 2,450.5$ & $\$ 159.2$ & $\$ 1,403.0$ \\
\hline Michigan & 21,633 & 10,283 & 4,685 & 6,665 & $\$ 1,940.9$ & $\$ 170.7$ & $\$ 1,124.1$ \\
\hline Minnesota & 15,718 & 7,746 & 3,295 & 4,677 & $\$ 1,482.9$ & $\$ 124.7$ & $\$ 851.3$ \\
\hline Mississippi & 6,239 & 3,864 & 1,197 & 1,178 & $\$ 390.8$ & $\$ 31.6$ & $\$ 238.2$ \\
\hline Missouri & 19,491 & 12,276 & 2,771 & 4,444 & $\$ 1,293.3$ & $\$ 90.2$ & $\$ 790.2$ \\
\hline
\end{tabular}


Table A2 | National Economic Impacts, All Pathways (Cont.)

\begin{tabular}{|c|c|c|c|c|c|c|c|}
\hline $\begin{array}{l}\text { AVERAGE IMPACTS } \\
\text { PER YEAR FOR } 5 \text { YEARS } \\
\text { NATIONAL }\end{array}$ & $\begin{array}{l}\text { TOTAL } \\
\text { JOBS PER } \\
\text { YEAR }\end{array}$ & $\begin{array}{l}\text { DIRECT } \\
\text { JOBS PER } \\
\text { YEAR }\end{array}$ & $\begin{array}{l}\text { INDIRECT } \\
\text { JOBS PER } \\
\text { YEAR }\end{array}$ & $\begin{array}{l}\text { INDUCED } \\
\text { JOBS PER } \\
\text { YEAR }\end{array}$ & $\begin{array}{l}\text { TOTAL VALUE } \\
\text { ADDED (GDP) PER } \\
\text { YEAR (S, MILLIONS) }\end{array}$ & $\begin{array}{l}\text { TOTAL TAXES ON } \\
\text { PRODUCTION AND } \\
\text { IMPORTS (TOPI) PER } \\
\text { YEAR (S, MILLIONS) }\end{array}$ & $\begin{array}{l}\text { TOTAL EMPLOYEE } \\
\text { COMPENSATION } \\
\text { (EMPLOYEE INCOME) } \\
\text { PER YEAR (S, MILLIONS) }\end{array}$ \\
\hline Montana & 9,790 & 6,057 & 1,839 & 1,894 & $\$ 595.9$ & $\$ 32.1$ & $\$ 388.7$ \\
\hline Nebraska & 6,026 & 3,740 & 920 & 1,366 & $\$ 409.9$ & $\$ 33.9$ & $\$ 251.4$ \\
\hline Nevada & 20,350 & 10,088 & 5,557 & 4,705 & $\$ 2,163.4$ & $\$ 188.6$ & $\$ 1,204.4$ \\
\hline New Hampshire & 3,190 & 1,453 & 684 & 1,053 & $\$ 265.5$ & $\$ 33.3$ & $\$ 145.2$ \\
\hline New Jersey & 7,502 & 3,531 & 1,743 & 2,228 & $\$ 843.6$ & $\$ 85.5$ & $\$ 453.5$ \\
\hline New Mexico & 16,106 & 9,622 & 3,603 & 2,881 & $\$ 919.2$ & $\$ 75.7$ & $\$ 604.6$ \\
\hline New York & 20,730 & 10,690 & 4,032 & 6,008 & $\$ 2,307,6$ & $\$ 205.9$ & $\$ 1,287,9$ \\
\hline North Carolina & 16,312 & 7,807 & 4,309 & 4,196 & $\$ 1,552.9$ & $\$ 113.6$ & $\$ 843.4$ \\
\hline North Dakota & 4,882 & 2,779 & 662 & 1,441 & $\$ 376.7$ & $\$ 44.3$ & $\$ 224.7$ \\
\hline Ohio & 22,353 & 11,531 & 4,462 & 6,360 & $\$ 1,894.9$ & $\$ 150.3$ & $\$ 1,030.0$ \\
\hline Oklahoma & 7,708 & 3,728 & 1,815 & 2,165 & $\$ 612.2$ & $\$ 62.1$ & $\$ 329.8$ \\
\hline Oregon & 15,785 & 7,496 & 4,156 & 4,133 & $\$ 1,448.7$ & $\$ 97.4$ & $\$ 872.8$ \\
\hline Pennsylvania & 26,225 & 12,206 & 5,760 & 8,260 & $\$ 2,830.4$ & $\$ 222.2$ & $\$ 1,435.0$ \\
\hline Rhode Island & 2,426 & 1,165 & 548 & 713 & $\$ 229.7$ & $\$ 25.4$ & $\$ 120.1$ \\
\hline South Carolina & 8,139 & 4,025 & 1,945 & 2,170 & $\$ 718.3$ & $\$ 70.5$ & $\$ 368.8$ \\
\hline South Dakota & 6,962 & 4,429 & 855 & 1,678 & $\$ 408.8$ & $\$ 49.8$ & $\$ 231.8$ \\
\hline Tennessee & 25,807 & 12,426 & 7,184 & 6,197 & $\$ 2,329.7$ & $\$ 173.0$ & $\$ 1,249.3$ \\
\hline Texas & 59,187 & 23,006 & 14,809 & 21,372 & $\$ 6,324,4$ & $\$ 671.1$ & $\$ 3,294,1$ \\
\hline Utah & 9,229 & 5,162 & 1,947 & 2,121 & $\$ 709.6$ & $\$ 53.9$ & $\$ 407.0$ \\
\hline Vermont & 5,140 & 2,815 & 1,064 & 1,261 & $\$ 362.4$ & $\$ 35.6$ & $\$ 219.7$ \\
\hline Virginia & 12,130 & 6,362 & 2,598 & 3,170 & $\$ 1,202.8$ & $\$ 99.7$ & $\$ 665.4$ \\
\hline Washington & 15,017 & 7,100 & 3,600 & 4,316 & $\$ 1,734.4$ & $\$ 174.3$ & $\$ 941.7$ \\
\hline West Virginia & 7,051 & 4,059 & 1,258 & 1,734 & $\$ 648.0$ & $\$ 77.6$ & $\$ 348.2$ \\
\hline Wisconsin & 14,163 & 7,378 & 2,832 & 3,953 & $\$ 1,227.0$ & $\$ 98.0$ & $\$ 687.4$ \\
\hline Wyoming & 9,503 & 5,738 & 2,106 & 1,658 & $\$ 601.8$ & $\$ 33.5$ & $\$ 391.7$ \\
\hline
\end{tabular}

Note: $\mathrm{GDP}=$ gross domestic product.

Source: BW Research. 


\section{APPENDIX B: RENEWABLE ENERGY: STATE- \\ LEVEL ECONOMIC INVESTMENT IMPACTS}

Table B1 provides the sum of economic outputs from investments in the rural renewable energy sector. The total values include the direct, indirect, and induced impacts on jobs, total value added, total employee compensation, and total taxes on production and imports. These impacts are interpreted as impacts per year for five years. The "rural impact case" refers to our assumption for the energy sector that 15 percent of federal investment is targeted at rural counties.

Table B1 | Rural Renewable Energy: State-Level Economic Investment Impacts

\section{AVERAGE IMPACTS PER YEAR FOR 5 YEARS RURAL IMPACT CASE}

\begin{abstract}
Alabama
\end{abstract}
Alaska

Arizona

Arkansas

California

Colorado

Connecticut

Delaware $^{a}$

District of Columbia

Florida

Georgia

Hawaii

Idaho

Illinois

Indiana

lowa

Kansas

Kentucky

Louisiana

Maine

Maryland

Massachusetts

Michigan

Minnesota

TOTAL
JOBS PER
YEAR

DIRECT
JOBS PER
YEAR

213

77

$28 \quad 12$

12

313

269

116

105

3,293

1,272

$1,200 \quad 394$

$83 \quad 33$

0

0

0

0

856

$\begin{array}{lll}630 & 245 & 153 \\ 323 & 147 & 70\end{array}$

289

237

14

14
0

$\begin{array}{ll}323 & 147 \\ 201 & 77\end{array}$

$\begin{array}{ll}147 & 70 \\ 77 & 42\end{array}$

162

$1,996 \quad 702 \quad 425$

232

$1,026 \quad 360 \quad 204$

10

$\begin{array}{llll}1,387 & 491 & 281 & 6 \\ 553 & 205 & 120 & 2\end{array}$

$42 \quad 82$

82

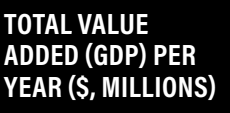

ADDED (GDP) PER
YEAR (\$, MILLIONS)

TOTAL TAXES ON

PRODUCTION AND IMPORTS (TOPI) PER

YEAR (S, MILLIONS)
TOTAL EMPLOYEE

COMPENSATION

(EMPLOYEE INCOME)

PER YEAR (\$, MILLIONS) 


\begin{tabular}{|c|c|c|c|c|c|c|c|}
\hline $\begin{array}{l}\text { AVERAGE IMPACTS } \\
\text { PER YEAR FOR } 5 \text { YEARS } \\
\text { RURAL IMPACT CASE }\end{array}$ & $\begin{array}{l}\text { TOTAL } \\
\text { JOBS PER } \\
\text { YEAR }\end{array}$ & $\begin{array}{l}\text { DIRECT } \\
\text { JOBS PER } \\
\text { YEAR }\end{array}$ & $\begin{array}{l}\text { INDIRECT } \\
\text { JOBS PER } \\
\text { YEAR }\end{array}$ & $\begin{array}{l}\text { INDUCED } \\
\text { JOBS PER } \\
\text { YEAR }\end{array}$ & $\begin{array}{l}\text { TOTAL VALUE } \\
\text { ADDED (GDP) PER } \\
\text { YEAR (S, MILLIONS) }\end{array}$ & $\begin{array}{l}\text { TOTAL TAXES ON } \\
\text { PRODUCTION AND } \\
\text { IMPORTS (TOPI) PER } \\
\text { YEAR (S, MILLIONS) }\end{array}$ & $\begin{array}{l}\text { TOTAL EMPLOYEE } \\
\text { COMPENSATION } \\
\text { (EMPLOYEE INCOME) } \\
\text { PER YEAR (S, MILLIONS) }\end{array}$ \\
\hline Mississippi & 302 & 137 & 75 & 91 & $\$ 20.6$ & $\$ 3.6$ & $\$ 10.7$ \\
\hline Missouri & 643 & 261 & 150 & 232 & $\$ 63.3$ & $\$ 8.2$ & $\$ 34.6$ \\
\hline Montana & 123 & 50 & 28 & 45 & $\$ 9.9$ & $\$ 1.6$ & $\$ 5.2$ \\
\hline Nebraska & 612 & 261 & 141 & 210 & $\$ 53.8$ & $\$ 7.5$ & $\$ 28.8$ \\
\hline Nevada & 604 & 263 & 152 & 189 & $\$ 68.9$ & $\$ 8.1$ & $\$ 35.8$ \\
\hline New Hampshire & 567 & 220 & 122 & 226 & $\$ 50.1$ & $\$ 8.6$ & $\$ 27.3$ \\
\hline New Jersey ${ }^{a}$ & 0 & 0 & 0 & 0 & $\$ 0.0$ & $\$ 0.0$ & $\$ 0.0$ \\
\hline New Mexico & 323 & 129 & 63 & 132 & $\$ 25.5$ & $\$ 5.6$ & $\$ 12.7$ \\
\hline New York & 737 & 263 & 132 & 343 & $\$ 89.0$ & $\$ 14.6$ & $\$ 43.1$ \\
\hline North Carolina & 667 & 269 & 166 & 233 & $\$ 74.7$ & $\$ 8.5$ & $\$ 36.4$ \\
\hline North Dakota & 666 & 229 & 126 & 312 & $\$ 53.6$ & $\$ 12.8$ & $\$ 29.8$ \\
\hline Ohio & 711 & 274 & 178 & 260 & $\$ 79.8$ & $\$ 9.2$ & $\$ 39.6$ \\
\hline Oklahoma & 608 & 222 & 135 & 252 & $\$ 48.3$ & $\$ 9.8$ & $\$ 24.8$ \\
\hline Oregon & 546 & 191 & 112 & 244 & $\$ 56.4$ & $\$ 9.6$ & $\$ 27.7$ \\
\hline Pennsylvania & 544 & 190 & 106 & 249 & $\$ 58.9$ & $\$ 9.9$ & $\$ 28.6$ \\
\hline Rhode Island ${ }^{a}$ & 0 & 0 & 0 & 0 & $\$ 0.0$ & $\$ 0.0$ & $\$ 0.0$ \\
\hline South Carolina & 294 & 104 & 58 & 132 & $\$ 25.7$ & $\$ 5.5$ & $\$ 11.8$ \\
\hline South Dakota & 685 & 249 & 132 & 304 & $\$ 45.4$ & $\$ 12.4$ & $\$ 22.5$ \\
\hline Tennessee & 435 & 177 & 113 & 145 & $\$ 44.1$ & $\$ 5.4$ & $\$ 21.9$ \\
\hline Texas & 3,916 & 1,273 & 793 & 1,850 & $\$ 442.3$ & $\$ 73.3$ & $\$ 212.0$ \\
\hline Utah & 304 & 115 & 71 & 118 & $\$ 35.2$ & $\$ 4.5$ & $\$ 16.7$ \\
\hline Vermont & 595 & 268 & 123 & 203 & $\$ 46.2$ & $\$ 7.5$ & $\$ 26.3$ \\
\hline Virginia & 462 & 178 & 96 & 188 & $\$ 53.5$ & $\$ 7.4$ & $\$ 26.1$ \\
\hline Washington & 567 & 196 & 110 & 262 & $\$ 67.2$ & $\$ 11.4$ & $\$ 29.4$ \\
\hline West Virginia & 208 & 80 & 44 & 84 & $\$ 18.4$ & $\$ 3.5$ & $\$ 9.5$ \\
\hline Wisconsin & 739 & 290 & 170 & 279 & $\$ 80.7$ & $\$ 10.2$ & $\$ 39.8$ \\
\hline Wyoming & 127 & 49 & 25 & 53 & $\$ 10.0$ & $\$ 2.3$ & $\$ 4.7$ \\
\hline
\end{tabular}

Notes: GDP = gross domestic product.a. Delaware, the District of Columbia, New Jersey, and Rhode Island do not have any rural counties as defined by the U.S. Department of Agriculture. Source: BW Research. 
Table B2 provides the sum of economic outputs from investments in the national renewable energy sector. The total values include the direct, indirect, and induced impacts on jobs, total value added, total employee compensa- tion, and total taxes. These impacts are interpreted as impacts per year for five years.

Table B2 | National Renewable Energy: State-Level Economic Investment Impacts

\begin{tabular}{|c|c|c|c|c|c|c|c|}
\hline $\begin{array}{l}\text { AVERAGE IMPACTS } \\
\text { PER YEAR FOR } 5 \text { YEARS } \\
\text { NATIONAL }\end{array}$ & $\begin{array}{l}\text { TOTAL } \\
\text { JOBS PER } \\
\text { YEAR }\end{array}$ & $\begin{array}{l}\text { DIRECT } \\
\text { JOBS PER } \\
\text { YEAR }\end{array}$ & $\begin{array}{l}\text { INDIRECT } \\
\text { JOBS PER } \\
\text { YEAR }\end{array}$ & $\begin{array}{l}\text { INDUCED } \\
\text { JOBS PER } \\
\text { YEAR }\end{array}$ & $\begin{array}{l}\text { TOTAL VALUE } \\
\text { ADDED (GDP) PER } \\
\text { YEAR (S, MILLIONS) }\end{array}$ & $\begin{array}{l}\text { TOTAL TAXES ON } \\
\text { PRODUCTION AND } \\
\text { IMPORTS (TOPI) PER } \\
\text { YEAR (S, MILLIONS) }\end{array}$ & $\begin{array}{l}\text { TOTAL EMPLOYEE } \\
\text { COMPENSATION } \\
\text { (EMPLOYEE INCOME) } \\
\text { PER YEAR (S, MILLIONS) }\end{array}$ \\
\hline Alabama & 1,056 & 339 & 186 & 531 & $\$ 76.4$ & $\$ 22.5$ & $\$ 40.0$ \\
\hline Alaska & 72 & 26 & 13 & 33 & $\$ 6.6$ & $\$ 1.3$ & $\$ 3.4$ \\
\hline Arizona & 2,003 & 739 & 340 & 923 & $\$ 215.9$ & $\$ 39.7$ & $\$ 101.6$ \\
\hline Arkansas & 760 & 253 & 142 & 364 & $\$ 50.3$ & $\$ 15.5$ & $\$ 23.6$ \\
\hline California & 20,723 & 7,996 & 3,504 & 9,223 & $\$ 2,981,9$ & $\$ 400.8$ & $\$ 1,347,7$ \\
\hline Colorado & 6,577 & 2,068 & 1,139 & 3,370 & $\$ 620.3$ & $\$ 142,6$ & $\$ 302.3$ \\
\hline Connecticut & 506 & 196 & 84 & 226 & $\$ 52.7$ & $\$ 9.8$ & $\$ 22.4$ \\
\hline Delaware & 112 & 43 & 18 & 51 & $\$ 8.3$ & $\$ 2.2$ & $\$ 4.4$ \\
\hline District of Columbia & 347 & 126 & 56 & 165 & $\$ 24.5$ & $\$ 7.2$ & $\$ 13.1$ \\
\hline Florida & 5,125 & 1,702 & 894 & 2,530 & $\$ 567.3$ & $\$ 108.0$ & $\$ 228.2$ \\
\hline Georgia & 1,835 & 676 & 356 & 803 & $\$ 205.1$ & $\$ 32.6$ & $\$ 98.9$ \\
\hline Hawaii & 889 & 368 & 163 & 358 & $\$ 95.1$ & $\$ 15.4$ & $\$ 43.1$ \\
\hline Idaho & 783 & 256 & 139 & 388 & $\$ 56.7$ & $\$ 16.3$ & $\$ 25.1$ \\
\hline Illinois & 7,492 & 2,352 & 1,344 & 3,796 & $\$ 852.5$ & $\$ 159.4$ & $\$ 404.0$ \\
\hline Indiana & 5,076 & 1,594 & 878 & 2,605 & $\$ 406.0$ & $\$ 110.0$ & $\$ 197.5$ \\
\hline lowa & 3,280 & 1,051 & 597 & 1,632 & $\$ 257.0$ & $\$ 68.9$ & $\$ 116.4$ \\
\hline Kansas & 1,791 & 576 & 327 & 887 & $\$ 134.6$ & $\$ 37.5$ & $\$ 61.9$ \\
\hline Kentucky & 442 & 174 & 90 & 178 & $\$ 37.5$ & $\$ 7.4$ & $\$ 19.1$ \\
\hline Louisiana & 933 & 368 & 183 & 381 & $\$ 94.0$ & $\$ 15.6$ & $\$ 44.5$ \\
\hline Maine & 1,191 & 399 & 222 & 570 & $\$ 83.4$ & $\$ 23.4$ & $\$ 38.9$ \\
\hline Maryland & 1,563 & 572 & 262 & 729 & $\$ 176.8$ & $\$ 31.6$ & $\$ 77.4$ \\
\hline Massachusetts & 3,687 & 1,347 & 608 & 1,732 & $\$ 420.0$ & $\$ 74.1$ & $\$ 219.5$ \\
\hline Michigan & 4,263 & 1,359 & 751 & 2,152 & $\$ 409.8$ & $\$ 90.1$ & $\$ 208.9$ \\
\hline Minnesota & 2,371 & 776 & 408 & 1,187 & $\$ 255.8$ & $\$ 50.4$ & $\$ 131.8$ \\
\hline Mississippi & 451 & 190 & 100 & 161 & $\$ 28.7$ & $\$ 6.7$ & $\$ 14.5$ \\
\hline Missouri & 1,579 & 563 & 308 & 709 & $\$ 135.8$ & $\$ 28.6$ & $\$ 72.4$ \\
\hline
\end{tabular}


Table B2 | National Renewable Energy: State-Level Economic Investment Impacts (Cont.)

\begin{tabular}{|c|c|c|c|c|c|c|c|}
\hline $\begin{array}{l}\text { AVERAGE IMPACTS } \\
\text { PER YEAR FOR } 5 \text { YEARS } \\
\text { NATIONAL }\end{array}$ & $\begin{array}{l}\text { TOTAL } \\
\text { JOBS PER } \\
\text { YEAR }\end{array}$ & $\begin{array}{l}\text { DIRECT } \\
\text { JOBS PER } \\
\text { YEAR }\end{array}$ & $\begin{array}{l}\text { INDIRECT } \\
\text { JOBS PER } \\
\text { YEAR }\end{array}$ & $\begin{array}{l}\text { INDUCED } \\
\text { JOBS PER } \\
\text { YEAR }\end{array}$ & $\begin{array}{l}\text { TOTAL VALUE } \\
\text { ADDED (GDP) PER } \\
\text { YEAR (S, MILLIONS) }\end{array}$ & $\begin{array}{l}\text { TOTAL TAXES ON } \\
\text { PRODUCTION AND } \\
\text { IMPORTS (TOPI) PER } \\
\text { YEAR (S, MILLIONS) }\end{array}$ & $\begin{array}{l}\text { TOTAL EMPLOYEE } \\
\text { COMPENSATION } \\
\text { (EMPLOYEE INCOME) } \\
\text { PER YEAR (S, MILLIONS) }\end{array}$ \\
\hline Montana & 161 & 63 & 34 & 64 & $\$ 12.8$ & $\$ 2.4$ & $\$ 6.5$ \\
\hline Nebraska & 984 & 381 & 204 & 399 & $\$ 77.8$ & $\$ 15.6$ & $\$ 40.1$ \\
\hline Nevada & 1,761 & 735 & 346 & 679 & $\$ 182.5$ & $\$ 29.8$ & $\$ 88.1$ \\
\hline New Hampshire & 1,227 & 427 & 232 & 568 & $\$ 97.6$ & $\$ 23.3$ & $\$ 50.2$ \\
\hline New Jersey & 1,816 & 679 & 304 & 832 & $\$ 197.6$ & $\$ 36.4$ & $\$ 92.3$ \\
\hline New Mexico & 1,278 & 455 & 220 & 602 & $\$ 90.0$ & $\$ 26.0$ & $\$ 42.0$ \\
\hline New York & 4,345 & 1,490 & 728 & 2,127 & $\$ 489.4$ & $\$ 91.7$ & $\$ 231.1$ \\
\hline North Carolina & 2,260 & 855 & 436 & 969 & $\$ 236.3$ & $\$ 40.3$ & $\$ 108.0$ \\
\hline North Dakota & 1,408 & 446 & 249 & 713 & $\$ 103.9$ & $\$ 30.0$ & $\$ 57.2$ \\
\hline Ohio & 2,363 & 870 & 457 & 1,036 & $\$ 258.9$ & $\$ 42.7$ & $\$ 118.0$ \\
\hline Oklahoma & 1,671 & 540 & 313 & 818 & $\$ 116.5$ & $\$ 34.1$ & $\$ 57.4$ \\
\hline Oregon & 1,871 & 654 & 333 & 884 & $\$ 189.1$ & $\$ 37.1$ & $\$ 91.0$ \\
\hline Pennsylvania & 2,809 & 920 & 483 & 1,406 & $\$ 278.6$ & $\$ 59.5$ & $\$ 129.8$ \\
\hline Rhode Island & 550 & 183 & 91 & 275 & $\$ 42.4$ & $\$ 11.9$ & $\$ 18.8$ \\
\hline South Carolina & 1,638 & 551 & 284 & 803 & $\$ 129.1$ & $\$ 34.4$ & $\$ 58.8$ \\
\hline South Dakota & 1,318 & 440 & 237 & 641 & $\$ 80.4$ & $\$ 26.9$ & $\$ 38.5$ \\
\hline Tennessee & 1,187 & 458 & 241 & 488 & $\$ 113.3$ & $\$ 20.2$ & $\$ 53.0$ \\
\hline Texas & 19,673 & 5,992 & 3,432 & 10,249 & $\$ 2,067,0$ & $\$ 432.2$ & $\$ 957.8$ \\
\hline Utah & 1,412 & 534 & 261 & 617 & $\$ 155.1$ & $\$ 26.1$ & $\$ 70.2$ \\
\hline Vermont & 845 & 354 & 164 & 327 & $\$ 62.8$ & $\$ 12.8$ & $\$ 34.5$ \\
\hline Virginia & 2,034 & 703 & 358 & 972 & $\$ 208.9$ & $\$ 41.2$ & $\$ 92.8$ \\
\hline Washington & 3,080 & 996 & 528 & 1,555 & $\$ 324.3$ & $\$ 67.2$ & $\$ 134.9$ \\
\hline West Virginia & 463 & 157 & 87 & 219 & $\$ 35.2$ & $\$ 9.3$ & $\$ 17.4$ \\
\hline Wisconsin & 1,987 & 690 & 379 & 919 & $\$ 189.9$ & $\$ 37.6$ & $\$ 88.5$ \\
\hline Wyoming & 139 & 54 & 27 & 58 & $\$ 11.3$ & $\$ 2.6$ & $\$ 5.2$ \\
\hline
\end{tabular}

Note: GDP = gross domestic product. Source: BW Research. 


\section{APPENDIX C: ENERGY EFFICIENCY: STATE- \\ LEVEL ECONOMIC INVESTMENT IMPACTS}

Table $\mathrm{C} 1$ provides the sum of economic outputs from investments in the rural energy efficiency sector. The total values include the direct, indirect, and induced impacts on jobs, employee compensation, value added, and taxes on production and imports. These impacts are interpreted as impacts per year for five years. The "rural impact case" refers to our assumption for the energy sector that 15 percent of federal investment is targeted at rural counties.

Table C1 | Rural Energy Efficiency: State-Level Economic Investment Impacts

\begin{tabular}{|c|c|c|c|c|c|c|c|}
\hline $\begin{array}{l}\text { AVERAGE IMPACTS } \\
\text { PER YEAR FOR } 5 \text { YEARS } \\
\text { RURAL IMPACT CASE }\end{array}$ & $\begin{array}{l}\text { TOTAL } \\
\text { JOBS PER } \\
\text { YEAR }\end{array}$ & $\begin{array}{l}\text { DIRECT } \\
\text { JOBS PER } \\
\text { YEAR }\end{array}$ & $\begin{array}{l}\text { INDIRECT } \\
\text { JOBS PER } \\
\text { YEAR }\end{array}$ & $\begin{array}{l}\text { INDUCED } \\
\text { JOBS PER } \\
\text { YEAR }\end{array}$ & $\begin{array}{l}\text { TOTAL VALUE } \\
\text { ADDED (GDP) PER } \\
\text { YEAR (S, MILLIONS) }\end{array}$ & $\begin{array}{l}\text { TOTAL TAXES ON } \\
\text { PRODUCTION AND } \\
\text { IMPORTS (TOPI) PER } \\
\text { YEAR (S, MILLIONS) }\end{array}$ & $\begin{array}{l}\text { TOTAL EMPLOYEE } \\
\text { COMPENSATION } \\
\text { (EMPLOYEE INCOME) } \\
\text { PER YEAR (S, MILLIONS) }\end{array}$ \\
\hline Alabama & 458 & 217 & 143 & 98 & $\$ 39.2$ & $\$ 2.2$ & $\$ 22.5$ \\
\hline Alaska & 87 & 45 & 21 & 21 & $\$ 8.9$ & $\$ 0.3$ & $\$ 5.0$ \\
\hline Arizona & 337 & 149 & 99 & 88 & $\$ 32.0$ & $\$ 2.0$ & $\$ 17.9$ \\
\hline Arkansas & 446 & 221 & 144 & 82 & $\$ 35.6$ & $\$ 2.5$ & $\$ 18.7$ \\
\hline California & 1,911 & 873 & 529 & 509 & $\$ 232.6$ & $\$ 12.9$ & $\$ 125.7$ \\
\hline Colorado & 451 & 189 & 134 & 128 & $\$ 48.0$ & $\$ 2.0$ & $\$ 28.5$ \\
\hline Connecticut & 285 & 139 & 76 & 70 & $\$ 31.6$ & $\$ 1.9$ & $\$ 16.4$ \\
\hline Delaware $^{a}$ & 0 & 0 & 0 & 0 & $\$ 0.0$ & $\$ 0.0$ & $\$ 0.0$ \\
\hline District of Columbia & 0 & 0 & 0 & 0 & $\$ 0.0$ & $\$ 0.0$ & $\$ 0.0$ \\
\hline Florida & 941 & 420 & 287 & 234 & $\$ 87.8$ & $\$ 5.8$ & $\$ 45.4$ \\
\hline Georgia & 773 & 334 & 245 & 194 & $\$ 77.0$ & $\$ 3.9$ & $\$ 40.2$ \\
\hline Hawaii & 78 & 39 & 20 & 20 & $\$ 8.7$ & $\$ 0.6$ & $\$ 4.5$ \\
\hline Idaho & 213 & 102 & 66 & 45 & $\$ 17.7$ & $\$ 0.8$ & $\$ 9.4$ \\
\hline Illinois & 982 & 422 & 279 & 280 & $\$ 109.4$ & $\$ 6.5$ & $\$ 61.3$ \\
\hline Indiana & 1,079 & 494 & 327 & 257 & $\$ 100.0$ & $\$ 6.5$ & $\$ 53.4$ \\
\hline lowa & 735 & 360 & 215 & 160 & $\$ 65.3$ & $\$ 3.8$ & $\$ 35.5$ \\
\hline Kansas & 410 & 194 & 124 & 93 & $\$ 39.1$ & $\$ 1.8$ & $\$ 22.6$ \\
\hline Kentucky & 788 & 375 & 245 & 169 & $\$ 68.8$ & $\$ 3.7$ & $\$ 37.1$ \\
\hline Louisiana & 259 & 123 & 74 & 62 & $\$ 22.6$ & $\$ 1.4$ & $\$ 12.9$ \\
\hline Maine & 359 & 162 & 108 & 89 & $\$ 28.0$ & $\$ 2.0$ & $\$ 15.9$ \\
\hline Maryland & 427 & 218 & 112 & 97 & $\$ 45.7$ & $\$ 2.8$ & $\$ 24.7$ \\
\hline Massachusetts & 511 & 239 & 121 & 151 & $\$ 60.1$ & $\$ 2.3$ & $\$ 35.3$ \\
\hline Michigan & 1,243 & 511 & 368 & 363 & $\$ 121.7$ & $\$ 5.4$ & $\$ 73.5$ \\
\hline Minnesota & 782 & 329 & 225 & 229 & $\$ 82.2$ & $\$ 4.6$ & $\$ 47,0$ \\
\hline
\end{tabular}




\begin{tabular}{|c|c|c|c|c|c|c|c|}
\hline $\begin{array}{l}\text { AVERAGE IMPACTS } \\
\text { PER YEAR FOR } 5 \text { YEARS } \\
\text { RURAL IMPACT CASE }\end{array}$ & $\begin{array}{l}\text { TOTAL } \\
\text { JOBS PER } \\
\text { YEAR }\end{array}$ & $\begin{array}{l}\text { DIRECT } \\
\text { JOBS PER } \\
\text { YEAR }\end{array}$ & $\begin{array}{l}\text { INDIRECT } \\
\text { JOBS PER } \\
\text { YEAR }\end{array}$ & $\begin{array}{l}\text { INDUCED } \\
\text { JOBS PER } \\
\text { YEAR }\end{array}$ & $\begin{array}{l}\text { TOTAL VALUE } \\
\text { ADDED (GDP) PER } \\
\text { YEAR (S, MILLIONS) }\end{array}$ & $\begin{array}{l}\text { TOTAL TAXES ON } \\
\text { PRODUCTION AND } \\
\text { IMPORTS (TOPI) PER } \\
\text { YEAR (S, MILLIONS) }\end{array}$ & $\begin{array}{l}\text { TOTAL EMPLOYEE } \\
\text { COMPENSATION } \\
\text { (EMPLOYEE INCOME) } \\
\text { PER YEAR (S, MILLIONS) }\end{array}$ \\
\hline Mississippi & 801 & 410 & 252 & 139 & $\$ 59.1$ & $\$ 4.7$ & $\$ 29.3$ \\
\hline Missouri & 647 & 285 & 196 & 166 & $\$ 59.2$ & $\$ 3.1$ & $\$ 34.4$ \\
\hline Montana & 609 & 286 & 184 & 139 & $\$ 47.3$ & $\$ 1.8$ & $\$ 26.8$ \\
\hline Nebraska & 465 & 222 & 142 & 100 & $\$ 37.4$ & $\$ 2.3$ & $\$ 23.2$ \\
\hline Nevada & 113 & 56 & 32 & 25 & $\$ 11.5$ & $\$ 0.9$ & $\$ 6.4$ \\
\hline New Hampshire & 472 & 213 & 139 & 119 & $\$ 42.7$ & $\$ 2.2$ & $\$ 25.0$ \\
\hline New Jersey & 0 & 0 & 0 & 0 & $\$ 0.0$ & $\$ 0.0$ & $\$ 0.0$ \\
\hline New Mexico & 129 & 67 & 34 & 29 & $\$ 11.5$ & $\$ 0.8$ & $\$ 6.7$ \\
\hline New York & 874 & 422 & 220 & 232 & $\$ 110.8$ & $\$ 5.8$ & $\$ 63.3$ \\
\hline North Carolina & 1,455 & 634 & 477 & 345 & $\$ 134.6$ & $\$ 6.6$ & $\$ 77.2$ \\
\hline North Dakota & 187 & 96 & 48 & 43 & $\$ 18.9$ & $\$ 0.8$ & $\$ 11.0$ \\
\hline Ohio & 1,488 & 628 & 458 & 401 & $\$ 144.4$ & $\$ 8.6$ & $\$ 77.2$ \\
\hline Oklahoma & 382 & 178 & 124 & 79 & $\$ 30.9$ & $\$ 1.7$ & $\$ 17.3$ \\
\hline Oregon & 503 & 224 & 151 & 128 & $\$ 48.7$ & $\$ 1.9$ & $\$ 27.3$ \\
\hline Pennsylvania & 678 & 300 & 188 & 191 & $\$ 70.9$ & $\$ 3.6$ & $\$ 38.9$ \\
\hline Rhode Island ${ }^{a}$ & 0 & 0 & 0 & 0 & $\$ 0.0$ & $\$ 0.0$ & $\$ 0.0$ \\
\hline South Carolina & 352 & 166 & 110 & 77 & $\$ 32.6$ & $\$ 1.9$ & $\$ 16.4$ \\
\hline South Dakota & 344 & 174 & 96 & 74 & $\$ 28.9$ & $\$ 2.0$ & $\$ 15.3$ \\
\hline Tennessee & 921 & 402 & 290 & 228 & $\$ 85.5$ & $\$ 5.6$ & $\$ 44.4$ \\
\hline Texas & 1,788 & 741 & 533 & 514 & $\$ 182.2$ & $\$ 8.6$ & $\$ 103.0$ \\
\hline Utah & 366 & 163 & 112 & 90 & $\$ 35.1$ & $\$ 1.7$ & $\$ 19.0$ \\
\hline Vermont & 682 & 329 & 193 & 160 & $\$ 53.7$ & $\$ 3.5$ & $\$ 31.2$ \\
\hline Virginia & 718 & 342 & 204 & 172 & $\$ 77.7$ & $\$ 3.9$ & $\$ 44.4$ \\
\hline Washington & 498 & 242 & 135 & 121 & $\$ 61.0$ & $\$ 4.5$ & $\$ 32.4$ \\
\hline West Virginia & 184 & 94 & 52 & 38 & $\$ 17.3$ & $\$ 1.1$ & $\$ 9.2$ \\
\hline Wisconsin & 1,152 & 506 & 346 & 299 & $\$ 111.1$ & $\$ 6.2$ & $\$ 60.0$ \\
\hline Wyoming & 449 & 254 & 129 & 66 & $\$ 39.1$ & $\$ 2.3$ & $\$ 20.5$ \\
\hline
\end{tabular}

Notes: GDP = gross domestic product.a. Delaware, the District of Columbia, New Jersey, and Rhode Island do not have any rural counties as defined by the U.S. Department of Agriculture. Source: BW Research. 
Table C2 provides the sum of economic outputs from investments in the national energy efficiency sector. The total values include the direct, indirect, and induced impacts on jobs, employee compensation, value added, and taxes on production and imports. These impacts are interpreted as impacts per year for five years.

Table C2 | National Energy Efficiency: State-Level Economic Investment Impacts

\begin{tabular}{|c|c|c|c|c|c|c|c|}
\hline $\begin{array}{l}\text { AVERAGE IMPACTS } \\
\text { PER YEAR FOR } 5 \text { YEARS } \\
\text { NATIONAL }\end{array}$ & $\begin{array}{l}\text { TOTAL } \\
\text { JOBS PER } \\
\text { YEAR }\end{array}$ & $\begin{array}{l}\text { DIRECT } \\
\text { JOBS PER } \\
\text { YEAR }\end{array}$ & $\begin{array}{l}\text { INDIRECT } \\
\text { JOBS PER } \\
\text { YEAR }\end{array}$ & $\begin{array}{l}\text { INDUCED } \\
\text { JOBS PER } \\
\text { YEAR }\end{array}$ & $\begin{array}{l}\text { TOTAL VALUE } \\
\text { ADDED (GDP) PER } \\
\text { YEAR (S, MILLIONS) }\end{array}$ & $\begin{array}{l}\text { TOTAL TAXES ON } \\
\text { PRODUCTION AND } \\
\text { IMPORTS (TOPI) PER } \\
\text { YEAR (S, MILLIONS) }\end{array}$ & $\begin{array}{l}\text { TOTAL EMPLOYEE } \\
\text { COMPENSATION } \\
\text { (EMPLOYEE INCOME) } \\
\text { PER YEAR (S, MILLIONS) }\end{array}$ \\
\hline Alabama & 1,571 & 780 & 469 & 322 & $\$ 126.7$ & $\$ 7.7$ & $\$ 71.0$ \\
\hline Alaska & 218 & 113 & 51 & 53 & $\$ 21.6$ & $\$ 0.8$ & $\$ 12.1$ \\
\hline Arizona & 2,012 & 903 & 596 & 514 & $\$ 181.4$ & $\$ 11.6$ & $\$ 99.8$ \\
\hline Arkansas & 924 & 474 & 283 & 167 & $\$ 71.5$ & $\$ 5.0$ & $\$ 37.0$ \\
\hline California & 11,863 & 5,461 & 3,323 & 3,079 & $\$ 1,371.1$ & $\$ 78.2$ & $\$ 726.9$ \\
\hline Colorado & 1,725 & 741 & 508 & 476 & $\$ 175.7$ & $\$ 7.7$ & $\$ 101.4$ \\
\hline Connecticut & 1,390 & 689 & 370 & 331 & $\$ 146.2$ & $\$ 9.2$ & $\$ 74.2$ \\
\hline Delaware & 426 & 227 & 108 & 90 & $\$ 41.0$ & $\$ 1.7$ & $\$ 20.9$ \\
\hline District of Columbia & 300 & 207 & 58 & 35 & $\$ 38.2$ & $\$ 1.4$ & $\$ 24.9$ \\
\hline Florida & 5,564 & 2,523 & 1,691 & 1,350 & $\$ 489.9$ & $\$ 33.0$ & $\$ 250.6$ \\
\hline Georgia & 3,023 & 1,371 & 916 & 735 & $\$ 284.2$ & $\$ 14.7$ & $\$ 145.4$ \\
\hline Hawaii & 250 & 127 & 59 & 64 & $\$ 27.2$ & $\$ 1.9$ & $\$ 13.8$ \\
\hline Idaho & 508 & 251 & 151 & 105 & $\$ 40.8$ & $\$ 2.0$ & $\$ 21.2$ \\
\hline Illinois & 3,978 & 1,780 & 1,100 & 1,098 & $\$ 421.5$ & $\$ 26.5$ & $\$ 231.1$ \\
\hline Indiana & 2,887 & 1,380 & 829 & 678 & $\$ 255.5$ & $\$ 16.2$ & $\$ 136.5$ \\
\hline lowa & 1,291 & 649 & 363 & 279 & $\$ 112.3$ & $\$ 6.5$ & $\$ 60.8$ \\
\hline Kansas & 949 & 457 & 282 & 210 & $\$ 87.9$ & $\$ 4.4$ & $\$ 49.9$ \\
\hline Kentucky & 1,522 & 747 & 454 & 321 & $\$ 129.2$ & $\$ 7.0$ & $\$ 68.8$ \\
\hline Louisiana & 1,089 & 538 & 298 & 253 & $\$ 90.2$ & $\$ 6.0$ & $\$ 51.3$ \\
\hline Maine & 646 & 300 & 189 & 157 & $\$ 49.2$ & $\$ 3.6$ & $\$ 27.6$ \\
\hline Maryland & 2,525 & 1,302 & 664 & 559 & $\$ 255.5$ & $\$ 16.1$ & $\$ 135.5$ \\
\hline Massachusetts & 3,165 & 1,494 & 761 & 909 & $\$ 353.1$ & $\$ 13.6$ & $\$ 203.8$ \\
\hline Michigan & 4,273 & 1,831 & 1,238 & 1,204 & $\$ 400.9$ & $\$ 19.0$ & $\$ 233.6$ \\
\hline Minnesota & 2,392 & 1,047 & 660 & 685 & $\$ 240.8$ & $\$ 14.0$ & $\$ 135.3$ \\
\hline Mississippi & 1,131 & 591 & 344 & 196 & $\$ 83.0$ & $\$ 6.7$ & $\$ 41.2$ \\
\hline
\end{tabular}




\begin{tabular}{|c|c|c|c|c|c|c|c|}
\hline $\begin{array}{l}\text { AVERAGE IMPACTS } \\
\text { PER YEAR FOR } 5 \text { YEARS } \\
\text { NATIONAL }\end{array}$ & $\begin{array}{l}\text { TOTAL } \\
\text { JOBS PER } \\
\text { YEAR }\end{array}$ & $\begin{array}{l}\text { DIRECT } \\
\text { JOBS PER } \\
\text { YEAR }\end{array}$ & $\begin{array}{l}\text { INDIRECT } \\
\text { JOBS PER } \\
\text { YEAR }\end{array}$ & $\begin{array}{l}\text { INDUCED } \\
\text { JOBS PER } \\
\text { YEAR }\end{array}$ & $\begin{array}{l}\text { TOTAL VALUE } \\
\text { ADDED (GDP) PER } \\
\text { YEAR (S, MILLIONS) }\end{array}$ & $\begin{array}{l}\text { TOTAL TAXES ON } \\
\text { PRODUCTION AND } \\
\text { IMPORTS (TOPI) PER } \\
\text { YEAR (S, MILLIONS) }\end{array}$ & $\begin{array}{l}\text { TOTAL EMPLOYEE } \\
\text { COMPENSATION } \\
\text { (EMPLOYEE INCOME) } \\
\text { PER YEAR (S, MILLIONS) }\end{array}$ \\
\hline Missouri & 2,183 & 1,005 & 641 & 537 & $\$ 188.3$ & $\$ 10.0$ & $\$ 107.5$ \\
\hline Montana & 765 & 363 & 227 & 175 & $\$ 59.9$ & $\$ 2.2$ & $\$ 33.7$ \\
\hline Nebraska & 910 & 447 & 270 & 193 & $\$ 71.1$ & $\$ 4.5$ & $\$ 43.8$ \\
\hline Nevada & 484 & 248 & 131 & 104 & $\$ 46.7$ & $\$ 3.7$ & $\$ 25.8$ \\
\hline New Hampshire & 811 & 373 & 235 & 203 & $\$ 71.8$ & $\$ 3.8$ & $\$ 41.6$ \\
\hline New Jersey & 1,303 & 630 & 347 & 325 & $\$ 143.2$ & $\$ 10.0$ & $\$ 73.2$ \\
\hline New Mexico & 306 & 162 & 79 & 65 & $\$ 25.9$ & $\$ 1.8$ & $\$ 14.9$ \\
\hline New York & 4,456 & 2,192 & 1,126 & 1,137 & $\$ 534.5$ & $\$ 29.2$ & $\$ 298.5$ \\
\hline North Carolina & 4,711 & 2,131 & 1,497 & 1,082 & $\$ 414.6$ & $\$ 21.0$ & $\$ 232.7$ \\
\hline North Dakota & 305 & 159 & 76 & 70 & $\$ 30.2$ & $\$ 1.2$ & $\$ 17.6$ \\
\hline Ohio & 4,475 & 1,975 & 1,315 & 1,185 & $\$ 417,0$ & $\$ 25.8$ & $\$ 219.3$ \\
\hline Oklahoma & 905 & 438 & 281 & 185 & $\$ 70.8$ & $\$ 3.9$ & $\$ 39.1$ \\
\hline Oregon & 1,997 & 918 & 578 & 501 & $\$ 184.6$ & $\$ 7.6$ & $\$ 102.1$ \\
\hline Pennsylvania & 3,030 & 1,377 & 824 & 829 & $\$ 300.3$ & $\$ 15.6$ & $\$ 161.4$ \\
\hline Rhode Island & 484 & 242 & 131 & 111 & $\$ 44.3$ & $\$ 2.7$ & $\$ 22.7$ \\
\hline South Carolina & 1,372 & 677 & 404 & 290 & $\$ 119.1$ & $\$ 7.2$ & $\$ 59.4$ \\
\hline South Dakota & 523 & 269 & 142 & 113 & $\$ 43.6$ & $\$ 3.0$ & $\$ 22.9$ \\
\hline Tennessee & 2,879 & 1,318 & 858 & 703 & $\$ 256.5$ & $\$ 17.0$ & $\$ 129.8$ \\
\hline Texas & 7,993 & 3,439 & 2,325 & 2,229 & $\$ 771.6$ & $\$ 37.7$ & $\$ 426.1$ \\
\hline Utah & 1,533 & 711 & 449 & 373 & $\$ 139.7$ & $\$ 7.0$ & $\$ 74.2$ \\
\hline Vermont & 920 & 449 & 257 & 215 & $\$ 72.1$ & $\$ 4.8$ & $\$ 41.7$ \\
\hline Virginia & 3,202 & 1,574 & 900 & 728 & $\$ 323.5$ & $\$ 17.2$ & $\$ 179.8$ \\
\hline Washington & 2,369 & 1,174 & 633 & 563 & $\$ 275.9$ & $\$ 21.3$ & $\$ 143.8$ \\
\hline West Virginia & 353 & 186 & 94 & 73 & $\$ 31.9$ & $\$ 2.0$ & $\$ 17.2$ \\
\hline Wisconsin & 3,310 & 1,513 & 949 & 848 & $\$ 306.2$ & $\$ 17.7$ & $\$ 163.7$ \\
\hline Wyoming & 529 & 301 & 149 & 78 & $\$ 46.6$ & $\$ 2.8$ & $\$ 24.6$ \\
\hline
\end{tabular}

Note: GDP = gross domestic product. Source: BW Research. 


\section{APPENDIX D: TRANSMISSION, DISTRIBUTION, \\ AND STORAGE: STATE-LEVEL ECONOMIC \\ INVESTMENT IMPACTS}

Table D1 provides the sum of economic outputs from investments in the rural transmission, distribution, and storage sector. The total values include the direct, indirect, and induced impacts on jobs, employee compensation, value added, and taxes on production and imports. These impacts are interpreted as impacts per year for five years. The "rural impact case" refers to our assumption for the energy sector that 15 percent of federal investment is targeted at rural counties.

Table D1 | Rural Transmission, Distribution, and Storage: State-Level Economic Investment Impacts

\begin{tabular}{|c|c|c|c|c|c|c|c|}
\hline $\begin{array}{l}\text { AVERAGE IMPACTS } \\
\text { PER YEAR FOR } 5 \text { YEARS } \\
\text { RURAL IMPACT CASE }\end{array}$ & $\begin{array}{l}\text { TOTAL } \\
\text { JOBS PER } \\
\text { YEAR }\end{array}$ & $\begin{array}{l}\text { DIRECT } \\
\text { JOBS PER } \\
\text { YEAR }\end{array}$ & $\begin{array}{l}\text { INDIRECT } \\
\text { JOBS PER } \\
\text { YEAR }\end{array}$ & $\begin{array}{l}\text { INDUCED } \\
\text { JOBS PER } \\
\text { YEAR }\end{array}$ & $\begin{array}{l}\text { TOTAL VALUE } \\
\text { ADDED (GDP) PER } \\
\text { YEAR (S, MILLIONS) }\end{array}$ & $\begin{array}{l}\text { TOTAL TAXES ON } \\
\text { PRODUCTION AND } \\
\text { IMPORTS (TOPI) PER } \\
\text { YEAR (S, MILLIONS) }\end{array}$ & $\begin{array}{l}\text { TOTAL EMPLOYEE } \\
\text { COMPENSATION } \\
\text { (EMPLOYEE INCOME) } \\
\text { PER YEAR (S, MILLIONS) }\end{array}$ \\
\hline Alabama & 511 & 248 & 147 & 116 & $\$ 50.1$ & $\$ 3.0$ & $\$ 28.8$ \\
\hline Alaska & 157 & 83 & 33 & 41 & $\$ 18.4$ & $\$ 0.9$ & $\$ 11.0$ \\
\hline Arizona & 713 & 290 & 219 & 204 & $\$ 80.9$ & $\$ 5.1$ & $\$ 44.2$ \\
\hline Arkansas & 506 & 259 & 150 & 97 & $\$ 44.7$ & $\$ 3.5$ & $\$ 24.2$ \\
\hline California & 6,428 & 2,558 & 1,958 & 1,912 & $\$ 969.6$ & $\$ 58.6$ & $\$ 518.0$ \\
\hline Colorado & 914 & 368 & 283 & 262 & $\$ 112.2$ & $\$ 5.6$ & $\$ 62.2$ \\
\hline Connecticut & 180 & 89 & 44 & 47 & $\$ 23.1$ & $\$ 1.6$ & $\$ 12.3$ \\
\hline Delaware $^{\mathrm{a}}$ & 0 & 0 & 0 & 0 & $\$ 0.0$ & $\$ 0.0$ & $\$ 0.0$ \\
\hline District of Columbia & 0 & 0 & 0 & 0 & $\$ 0.0$ & $\$ 0.0$ & $\$ 0.0$ \\
\hline Florida & 1,841 & 727 & 599 & 515 & $\$ 209.0$ & $\$ 14.9$ & $\$ 108.4$ \\
\hline Georgia & 1,219 & 503 & 372 & 344 & $\$ 147.0$ & $\$ 7.9$ & $\$ 76.6$ \\
\hline Hawaii & 145 & 73 & 36 & 35 & $\$ 17.0$ & $\$ 1.3$ & $\$ 8.8$ \\
\hline Idaho & 370 & 186 & 101 & 83 & $\$ 34.6$ & $\$ 1.8$ & $\$ 18.6$ \\
\hline Illinois & 1,445 & 588 & 414 & 442 & $\$ 190.5$ & $\$ 13.0$ & $\$ 104.0$ \\
\hline Indiana & 1,062 & 498 & 291 & 273 & $\$ 109.9$ & $\$ 6.6$ & $\$ 60.9$ \\
\hline lowa & 1,029 & 505 & 294 & 230 & $\$ 103.2$ & $\$ 7.3$ & $\$ 57.0$ \\
\hline Kansas & 674 & 324 & 201 & 149 & $\$ 74.6$ & $\$ 4.7$ & $\$ 38.9$ \\
\hline Kentucky & 953 & 443 & 304 & 206 & $\$ 93.0$ & $\$ 5.7$ & $\$ 50.8$ \\
\hline Louisiana & 502 & 234 & 146 & 123 & $\$ 50.2$ & $\$ 3.3$ & $\$ 28.5$ \\
\hline Maine & 320 & 152 & 85 & 83 & $\$ 28.8$ & $\$ 2.2$ & $\$ 15.9$ \\
\hline Maryland & 509 & 244 & 132 & 133 & $\$ 66.8$ & $\$ 4.5$ & $\$ 36.3$ \\
\hline Massachusetts & 1,804 & 787 & 445 & 572 & $\$ 252.9$ & $\$ 10.6$ & $\$ 147.2$ \\
\hline Michigan & 1,180 & 492 & 346 & 343 & $\$ 130.5$ & $\$ 7.2$ & $\$ 74.5$ \\
\hline
\end{tabular}


Table D1 | Rural Transmission, Distribution, and Storage: State-Level Economic Investment Impacts (Cont.)

\begin{tabular}{|c|c|c|c|c|c|c|c|}
\hline $\begin{array}{l}\text { AVERAGE IMPACTS } \\
\text { PER YEAR FOR } 5 \text { YEARS } \\
\text { RURAL IMPACT CASE }\end{array}$ & $\begin{array}{l}\text { TOTAL } \\
\text { JOBS PER } \\
\text { YEAR }\end{array}$ & $\begin{array}{l}\text { DIRECT } \\
\text { JOBS PER } \\
\text { YEAR }\end{array}$ & $\begin{array}{l}\text { INDIRECT } \\
\text { JOBS PER } \\
\text { YEAR }\end{array}$ & $\begin{array}{l}\text { INDUCED } \\
\text { JOBS PER } \\
\text { YEAR }\end{array}$ & $\begin{array}{l}\text { TOTAL VALUE } \\
\text { ADDED (GDP) PER } \\
\text { YEAR (S, MILLIONS) }\end{array}$ & $\begin{array}{l}\text { TOTAL TAXES ON } \\
\text { PRODUCTION AND } \\
\text { IMPORTS (TOPI) PER } \\
\text { YEAR (S, MILLIONS) }\end{array}$ & $\begin{array}{l}\text { TOTAL EMPLOYEE } \\
\text { COMPENSATION } \\
\text { (EMPLOYEE INCOME) } \\
\text { PER YEAR (S, MILLIONS) }\end{array}$ \\
\hline Minnesota & 1,138 & 458 & 337 & 344 & $\$ 138.0$ & $\$ 8.8$ & $\$ 77.9$ \\
\hline Mississippi & 817 & 426 & 247 & 145 & $\$ 61.1$ & $\$ 4.9$ & $\$ 33.7$ \\
\hline Missouri & 638 & 289 & 185 & 165 & $\$ 65.6$ & $\$ 3.9$ & $\$ 37.3$ \\
\hline Montana & 411 & 198 & 116 & 97 & $\$ 36.3$ & $\$ 2.3$ & $\$ 20.3$ \\
\hline Nebraska & 301 & 145 & 84 & 72 & $\$ 29.2$ & $\$ 1.8$ & $\$ 16.8$ \\
\hline Nevada & 2,446 & 1,135 & 747 & 565 & $\$ 287.5$ & $\$ 22.9$ & $\$ 159.6$ \\
\hline New Hampshire & 208 & 97 & 55 & 55 & $\$ 20.8$ & $\$ 1.5$ & $\$ 12.4$ \\
\hline New Jersey ${ }^{a}$ & 0 & 0 & 0 & 0 & $\$ 0.0$ & $\$ 0.0$ & $\$ 0.0$ \\
\hline New Mexico & 423 & 228 & 104 & 91 & $\$ 41.4$ & $\$ 3.5$ & $\$ 22.8$ \\
\hline New York & 1,007 & 471 & 260 & 275 & $\$ 146.9$ & $\$ 9.3$ & $\$ 82.4$ \\
\hline North Carolina & 1,723 & 756 & 534 & 433 & $\$ 194.4$ & $\$ 11.6$ & $\$ 101.6$ \\
\hline North Dakota & 604 & 305 & 156 & 142 & $\$ 71.4$ & $\$ 4.1$ & $\$ 41.5$ \\
\hline Ohio & 1,326 & 544 & 410 & 371 & $\$ 142.9$ & $\$ 9.6$ & $\$ 77.8$ \\
\hline Oklahoma & 1,193 & 550 & 371 & 271 & $\$ 113.6$ & $\$ 6.6$ & $\$ 63.2$ \\
\hline Oregon & 790 & 336 & 240 & 215 & $\$ 95.3$ & $\$ 4.5$ & $\$ 49.9$ \\
\hline Pennsylvania & 996 & 430 & 267 & 299 & $\$ 123.6$ & $\$ 7.7$ & $\$ 67.3$ \\
\hline Rhode Island ${ }^{a}$ & 0 & 0 & 0 & 0 & $\$ 0.0$ & $\$ 0.0$ & $\$ 0.0$ \\
\hline South Carolina & 526 & 242 & 163 & 121 & $\$ 59.0$ & $\$ 3.7$ & $\$ 28.5$ \\
\hline South Dakota & 395 & 206 & 99 & 89 & $\$ 36.4$ & $\$ 2.6$ & $\$ 20.0$ \\
\hline Tennessee & 2,718 & 1,172 & 879 & 666 & $\$ 273.4$ & $\$ 18.8$ & $\$ 145.4$ \\
\hline Texas & 4,117 & 1,620 & 1,274 & 1,223 & $\$ 495.0$ & $\$ 27.6$ & $\$ 266.5$ \\
\hline Utah & 328 & 126 & 114 & 88 & $\$ 38.5$ & $\$ 2.1$ & $\$ 20.2$ \\
\hline Vermont & 953 & 495 & 225 & 232 & $\$ 76.8$ & $\$ 6.3$ & $\$ 47.4$ \\
\hline Virginia & 639 & 301 & 172 & 166 & $\$ 82.5$ & $\$ 5.0$ & $\$ 46.1$ \\
\hline Washington & 817 & 366 & 235 & 217 & $\$ 126.4$ & $\$ 9.7$ & $\$ 64.4$ \\
\hline West Virginia & 469 & 225 & 131 & 114 & $\$ 52.2$ & $\$ 4.3$ & $\$ 29.4$ \\
\hline Wisconsin & 869 & 379 & 250 & 240 & $\$ 99.5$ & $\$ 6.2$ & $\$ 52.8$ \\
\hline Wyoming & 486 & 276 & 127 & 83 & $\$ 54.4$ & $\$ 4.2$ & $\$ 27.7$ \\
\hline
\end{tabular}

Notes: GDP = gross domestic product.a. Delaware, the District of Columbia, New Jersey, and Rhode Island do not have any rural counties as defined by the U.S. Department of Agriculture. Source: BW Research. 
Table D2 provides the sum of economic outputs from investments in the national transmission, distribution, and storage sector. The total values include the direct, indirect, and induced impacts on jobs, employee compensation, value added, and taxes on production and imports. These impacts are interpreted as impacts per year for five years.

Table D2 | National Transmission, Distribution, and Storage: State-Level Economic Investment Impactst

\begin{tabular}{|c|c|c|c|c|c|c|c|}
\hline $\begin{array}{l}\text { AVERAGE IMPACTS } \\
\text { PER YEAR FOR } 5 \text { YEARS } \\
\text { NATIONAL }\end{array}$ & $\begin{array}{l}\text { TOTAL } \\
\text { JOBS PER } \\
\text { YEAR }\end{array}$ & $\begin{array}{l}\text { DIRECT } \\
\text { JOBS PER } \\
\text { YEAR }\end{array}$ & $\begin{array}{l}\text { INDIRECT } \\
\text { JOBS PER } \\
\text { YEAR }\end{array}$ & $\begin{array}{l}\text { INDUCED } \\
\text { JOBS PER } \\
\text { YEAR }\end{array}$ & $\begin{array}{l}\text { TOTAL VALUE } \\
\text { ADDED (GDP) PER } \\
\text { YEAR (S, MILLIONS) }\end{array}$ & $\begin{array}{l}\text { TOTAL TAXES ON } \\
\text { PRODUCTION AND } \\
\text { IMPORTS (TOPI) PER } \\
\text { YEAR (S, MILLIONS) }\end{array}$ & $\begin{array}{l}\text { TOTAL EMPLOYEE } \\
\text { COMPENSATION } \\
\text { (EMPLOYEE INCOME) } \\
\text { PER YEAR (S, MILLIONS) }\end{array}$ \\
\hline Alabama & 3,444 & 1,691 & 980 & 773 & $\$ 329.6$ & $\$ 19.8$ & $\$ 189.6$ \\
\hline Alaska & 548 & 291 & 114 & 143 & $\$ 63.8$ & $\$ 3.0$ & $\$ 38.3$ \\
\hline Arizona & 4,819 & 1,995 & 1,466 & 1,358 & $\$ 529.1$ & $\$ 34.0$ & $\$ 288.9$ \\
\hline Arkansas & 1,547 & 796 & 456 & 295 & $\$ 136.4$ & $\$ 10.6$ & $\$ 73.8$ \\
\hline California & 43,445 & 17,603 & 13,095 & 12,746 & $\$ 6,329.5$ & $\$ 387.9$ & $\$ 3,383.3$ \\
\hline Colorado & 6,162 & 2,520 & 1,893 & 1,749 & $\$ 735.4$ & $\$ 37.3$ & $\$ 407.6$ \\
\hline Connecticut & 1,218 & 609 & 296 & 313 & $\$ 151.0$ & $\$ 10.6$ & $\$ 80.8$ \\
\hline Delaware & 350 & 187 & 77 & 86 & $\$ 41.2$ & $\$ 2.0$ & $\$ 23.2$ \\
\hline District of Columbia & 374 & 254 & 75 & 46 & $\$ 53.0$ & $\$ 2.5$ & $\$ 35.2$ \\
\hline Florida & 12,436 & 4,996 & 4,003 & 3,436 & $\$ 1,364.9$ & $\$ 98.4$ & $\$ 708.5$ \\
\hline Georgia & 8,208 & 3,434 & 2,482 & 2,292 & $\$ 964.3$ & $\$ 52.6$ & $\$ 503.0$ \\
\hline Hawaii & 975 & 495 & 243 & 236 & $\$ 111.7$ & $\$ 8.8$ & $\$ 57.9$ \\
\hline Idaho & 2,132 & 1,079 & 577 & 476 & $\$ 195.2$ & $\$ 10.4$ & $\$ 105.2$ \\
\hline Illinois & 9,734 & 4,021 & 2,766 & 2,948 & $\$ 1,250,1$ & $\$ 86.4$ & $\$ 683.3$ \\
\hline Indiana & 6,169 & 2,921 & 1,674 & 1,574 & $\$ 626.4$ & $\$ 37.7$ & $\$ 347.3$ \\
\hline lowa & 2,808 & 1,383 & 798 & 628 & $\$ 282.0$ & $\$ 19.9$ & $\$ 155.9$ \\
\hline Kansas & 1,932 & 932 & 572 & 427 & $\$ 213.5$ & $\$ 13.4$ & $\$ 111.4$ \\
\hline Kentucky & 2,671 & 1,246 & 849 & 577 & $\$ 260.5$ & $\$ 16.0$ & $\$ 142.5$ \\
\hline Louisiana & 3,382 & 1,592 & 973 & 817 & $\$ 329.5$ & $\$ 21.6$ & $\$ 187.6$ \\
\hline Maine & 1,152 & 550 & 306 & 296 & $\$ 103.0$ & $\$ 7.8$ & $\$ 56.7$ \\
\hline Maryland & 3,443 & 1,675 & 883 & 885 & $\$ 436.7$ & $\$ 29.6$ & $\$ 237.3$ \\
\hline Massachusetts & 12,206 & 5,416 & 2,976 & 3,814 & $\$ 1,651.7$ & $\$ 70.3$ & $\$ 962.1$ \\
\hline Michigan & 7,939 & 3,346 & 2,309 & 2,284 & $\$ 858.8$ & $\$ 47.6$ & $\$ 490.6$ \\
\hline Minnesota & 5,772 & 2,344 & 1,694 & 1,734 & $\$ 688.8$ & $\$ 44.3$ & $\$ 389.3$ \\
\hline Mississippi & 1,650 & 858 & 497 & 294 & $\$ 125.3$ & $\$ 9.9$ & $\$ 69.1$ \\
\hline
\end{tabular}


Table D2 | National Transmission, Distribution, and Storage: State-Level Economic Investment Impactst (Cont.)

\begin{tabular}{|c|c|c|c|c|c|c|c|}
\hline $\begin{array}{l}\text { AVERAGE IMPACTS } \\
\text { PER YEAR FOR } 5 \text { YEARS } \\
\text { NATIONAL }\end{array}$ & $\begin{array}{l}\text { TOTAL } \\
\text { JOBS PER } \\
\text { YEAR }\end{array}$ & $\begin{array}{l}\text { DIRECT } \\
\text { JOBS PER } \\
\text { YEAR }\end{array}$ & $\begin{array}{l}\text { INDIRECT } \\
\text { JOBS PER } \\
\text { YEAR }\end{array}$ & $\begin{array}{l}\text { INDUCED } \\
\text { JOBS PER } \\
\text { YEAR }\end{array}$ & $\begin{array}{l}\text { TOTAL VALUE } \\
\text { ADDED (GDP) PER } \\
\text { YEAR (\$, MILLIONS) }\end{array}$ & $\begin{array}{l}\text { TOTAL TAXES ON } \\
\text { PRODUCTION AND } \\
\text { IMPORTS (TOPI) PER } \\
\text { YEAR (\$, MILLIONS) }\end{array}$ & $\begin{array}{l}\text { TOTAL EMPLOYEE } \\
\text { COMPENSATION } \\
\text { (EMPLOYEE INCOME) } \\
\text { PER YEAR (\$, MILLIONS) }\end{array}$ \\
\hline Missouri & 3,694 & 1,687 & 1,062 & 945 & $\$ 372.3$ & $\$ 22.2$ & $\$ 211.9$ \\
\hline Montana & 733 & 351 & 207 & 175 & $\$ 66.1$ & $\$ 4.1$ & $\$ 37.0$ \\
\hline Nebraska & 984 & 477 & 273 & 235 & $\$ 94.8$ & $\$ 5.8$ & $\$ 54.5$ \\
\hline Nevada & 16,565 & 7,806 & 4,995 & 3,765 & $\$ 1,876.1$ & $\$ 152.0$ & $\$ 1,042.2$ \\
\hline New Hampshire & 661 & 311 & 176 & 174 & $\$ 66.0$ & $\$ 4.9$ & $\$ 39.5$ \\
\hline New Jersey & 3,310 & 1,458 & 962 & 890 & $\$ 437.8$ & $\$ 34.4$ & $\$ 234.2$ \\
\hline New Mexico & 1,242 & 670 & 305 & 267 & $\$ 121.3$ & $\$ 10.2$ & $\$ 66.9$ \\
\hline New York & 6,808 & 3,236 & 1,740 & 1,833 & $\$ 960.4$ & $\$ 61.5$ & $\$ 539.5$ \\
\hline North Carolina & 6,777 & 2,994 & 2,086 & 1,697 & $\$ 756.5$ & $\$ 45.3$ & $\$ 395.8$ \\
\hline North Dakota & 874 & 437 & 227 & 210 & $\$ 107.1$ & $\$ 6.1$ & $\$ 62.3$ \\
\hline Ohio & 6,795 & 2,816 & 2,088 & 1,891 & $\$ 720.6$ & $\$ 48.9$ & $\$ 392.5$ \\
\hline Oklahoma & 3,291 & 1,522 & 1,020 & 749 & $\$ 313.5$ & $\$ 18.2$ & $\$ 174.7$ \\
\hline Oregon & 5,323 & 2,293 & 1,599 & 1,430 & $\$ 625.3$ & $\$ 29.8$ & $\$ 327.6$ \\
\hline Pennsylvania & 6,710 & 2,934 & 1,784 & 1,993 & $\$ 812.0$ & $\$ 51.1$ & $\$ 442.5$ \\
\hline Rhode Island & 1,269 & 627 & 320 & 322 & $\$ 140.8$ & $\$ 10.4$ & $\$ 76.0$ \\
\hline South Carolina & 3,552 & 1,656 & 1,090 & 806 & $\$ 386.5$ & $\$ 24.3$ & $\$ 186.5$ \\
\hline South Dakota & 904 & 472 & 226 & 205 & $\$ 83.8$ & $\$ 6.1$ & $\$ 46.2$ \\
\hline Tennessee & 18,303 & 7,995 & 5,866 & 4,442 & $\$ 1,795,6$ & $\$ 125.3$ & $\$ 955.2$ \\
\hline Texas & 27,743 & 11,084 & 8,504 & 8,155 & $\$ 3,243.9$ & $\$ 183.0$ & $\$ 1,748.2$ \\
\hline Utah & 2,205 & 859 & 761 & 585 & $\$ 252.5$ & $\$ 13.7$ & $\$ 132.4$ \\
\hline Vermont & 2,337 & 1,215 & 550 & 571 & $\$ 189.2$ & $\$ 15.6$ & $\$ 116.9$ \\
\hline Virginia & 4,312 & 2,055 & 1,148 & 1,109 & $\$ 541.4$ & $\$ 33.2$ & $\$ 303.0$ \\
\hline Washington & 5,524 & 2,509 & 1,569 & 1,446 & $\$ 826.7$ & $\$ 64.6$ & $\$ 421.2$ \\
\hline West Virginia & 1,267 & 608 & 352 & 307 & $\$ 141.1$ & $\$ 11.6$ & $\$ 79.8$ \\
\hline Wisconsin & 4,188 & 1,840 & 1,197 & 1,150 & $\$ 471.9$ & $\$ 29.7$ & $\$ 250.7$ \\
\hline Wyoming & 648 & 365 & 170 & 113 & $\$ 75.8$ & $\$ 5.8$ & $\$ 38.7$ \\
\hline
\end{tabular}

Note: GDP = gross domestic product. Source: BW Research. 


\section{APPENDIX E: ORPHANED OIL AND \\ GAS WELLS: STATE-LEVEL ECONOMIC \\ INVESTMENT IMPACTS}

Table E1 provides the sum of economic outputs from investments in the environmental remediation of orphaned oil and gas wells located in rural counties. The total values include the direct, indirect, and induced impacts on jobs, employee compensation, value added, and taxes on production and imports. These impacts are interpreted as impacts per year for five years.

Table E1 | Environmental Remediation of Orphaned Oil and Gas Wells in Rural Counties: State-Level Economic Investment Impacts

\begin{tabular}{|c|c|c|c|c|c|c|c|}
\hline $\begin{array}{l}\text { AVERAGE IMPACTS } \\
\text { PER YEAR FOR } 5 \text { YEARS } \\
\text { RURAL }\end{array}$ & $\begin{array}{l}\text { TOTAL } \\
\text { JOBS PER } \\
\text { YEAR }\end{array}$ & $\begin{array}{l}\text { DIRECT } \\
\text { JOBS PER } \\
\text { YEAR }\end{array}$ & $\begin{array}{l}\text { INDIRECT } \\
\text { JOBS PER } \\
\text { YEAR }\end{array}$ & $\begin{array}{l}\text { INDUCED } \\
\text { JOBS PER } \\
\text { YEAR }\end{array}$ & $\begin{array}{l}\text { TOTAL VALUE } \\
\text { ADDED (GDP) PER } \\
\text { YEAR (S, MILLIONS) }\end{array}$ & $\begin{array}{l}\text { TOTAL TAXES ON } \\
\text { PRODUCTION AND } \\
\text { IMPORTS (TOPI) PER } \\
\text { YEAR (S, MILLIONS) }\end{array}$ & $\begin{array}{l}\text { TOTAL EMPLOYEE } \\
\text { COMPENSATION } \\
\text { (EMPLOYEE INCOME) } \\
\text { PER YEAR (\$, MILLIONS) }\end{array}$ \\
\hline Alabama & 0 & 0 & 0 & 0 & $\$ 0.0$ & $\$ 0.0$ & $\$ 0.0$ \\
\hline Alaska & 2 & 1 & 0 & 0 & $\$ 0.2$ & $\$ 0.0$ & $\$ 0.1$ \\
\hline Arkansas & 37 & 17 & 13 & 6 & $\$ 3.3$ & $\$ 0.6$ & $\$ 1.7$ \\
\hline California & 7 & 3 & 2 & 2 & $\$ 0.9$ & $\$ 0.1$ & $\$ 0.5$ \\
\hline Colorado & 30 & 12 & 10 & 8 & $\$ 3.4$ & $\$ 0.3$ & $\$ 1.9$ \\
\hline Illinois & 467 & 171 & 182 & 114 & $\$ 48.7$ & $\$ 6.1$ & $\$ 27.9$ \\
\hline Indiana & 114 & 45 & 48 & 21 & $\$ 8.6$ & $\$ 2.0$ & $\$ 4.6$ \\
\hline Kansas & 720 & 287 & 308 & 126 & $\$ 60.3$ & $\$ 7.7$ & $\$ 33.0$ \\
\hline Kentucky & 1,456 & 636 & 577 & 243 & $\$ 119.2$ & $\$ 15.8$ & $\$ 67.8$ \\
\hline Louisiana & 185 & 84 & 59 & 43 & $\$ 18.8$ & $\$ 2.1$ & $\$ 10.6$ \\
\hline Michigan & 13 & 5 & 5 & 3 & $\$ 1.1$ & $\$ 0.1$ & $\$ 0.7$ \\
\hline Mississippi & 2 & 1 & 1 & 0 & $\$ 0.1$ & $\$ 0.0$ & $\$ 0.1$ \\
\hline Montana & 22 & 9 & 7 & 5 & $\$ 1.9$ & $\$ 0.3$ & $\$ 1.1$ \\
\hline Nebraska & 10 & 4 & 4 & 2 & $\$ 0.8$ & $\$ 0.1$ & $\$ 0.4$ \\
\hline Nevada & 1 & 0 & 0 & 0 & $\$ 0.0$ & $\$ 0.0$ & $\$ 0.0$ \\
\hline New Mexico & 54 & 29 & 14 & 12 & $\$ 5.6$ & $\$ 1.0$ & $\$ 3.2$ \\
\hline New York & 306 & 97 & 79 & 130 & $\$ 36.1$ & $\$ 4.4$ & $\$ 19.7$ \\
\hline Ohio & 76 & 37 & 22 & 17 & $\$ 8.9$ & $\$ 1.1$ & $\$ 3.8$ \\
\hline Oklahoma & 93 & 43 & 31 & 19 & $\$ 8.9$ & $\$ 1.0$ & $\$ 4.8$ \\
\hline Pennsylvania & 973 & 444 & 281 & 248 & $\$ 115.1$ & $\$ 11.7$ & $\$ 60.6$ \\
\hline Texas & 634 & 264 & 198 & 172 & $\$ 72.7$ & $\$ 8.9$ & $\$ 38.3$ \\
\hline Utah & 5 & 2 & 2 & 1 & $\$ 0.5$ & $\$ 0.1$ & $\$ 0.3$ \\
\hline Virginia & 1 & 0 & 0 & 0 & $\$ 0.1$ & $\$ 0.0$ & $\$ 0.1$ \\
\hline West Virginia & 348 & 184 & 100 & 64 & $\$ 34.7$ & $\$ 4.0$ & $\$ 18.1$ \\
\hline Wyoming & 212 & 117 & 63 & 32 & $\$ 20.5$ & $\$ 3.0$ & $\$ 12.5$ \\
\hline
\end{tabular}

Notes: This table only includes states with documented orphaned oil and gas wells; GDP = gross domestic product.

Source: BW Research. 
Table E2 provides the sum of economic outputs from investments in the environmental remediation of orphaned oil and gas wells nationally. The total values include the direct, indirect, and induced impacts on jobs, employee compensation, value added, and taxes on production and imports. These impacts are interpreted as impacts per year for five years.

Table E2 | Environmental Remediation of Orphaned Oil and Gas Wells in Rural and Urban Counties: State-Level Economic Investment Impacts

\begin{tabular}{|c|c|c|c|c|c|c|c|}
\hline $\begin{array}{l}\text { AVERAGE IMPACTS } \\
\text { PER YEAR FOR } 5 \text { YEARS } \\
\text { NATIONAL }\end{array}$ & $\begin{array}{l}\text { TOTAL } \\
\text { JOBS PER } \\
\text { YEAR }\end{array}$ & $\begin{array}{l}\text { DIRECT } \\
\text { JOBS PER } \\
\text { YEAR }\end{array}$ & $\begin{array}{l}\text { INDIRECT } \\
\text { JOBS PER } \\
\text { YEAR }\end{array}$ & $\begin{array}{l}\text { INDUCED } \\
\text { JOBS PER } \\
\text { YEAR }\end{array}$ & $\begin{array}{l}\text { TOTAL VALUE } \\
\text { ADDED (GDP) PER } \\
\text { YEAR (S, MILLIONS) }\end{array}$ & $\begin{array}{l}\text { TOTAL TAXES ON } \\
\text { PRODUCTION AND } \\
\text { IMPORTS (TOPI) PER } \\
\text { YEAR (S, MILLIONS) }\end{array}$ & $\begin{array}{l}\text { TOTAL EMPLOYEE } \\
\text { COMPENSATION } \\
\text { (EMPLOYEE INCOME) } \\
\text { PER YEAR (S, MILLIONS) }\end{array}$ \\
\hline Alabama & 0 & 0 & 0 & 0 & $\$ 0.0$ & $\$ 0.0$ & $\$ 0.0$ \\
\hline Alaska & 2 & 1 & 0 & 0 & $\$ 0.2$ & $\$ 0.0$ & $\$ 0.1$ \\
\hline Arkansas & 54 & 25 & 19 & 9 & $\$ 4.7$ & $\$ 0.9$ & $\$ 2.4$ \\
\hline California & 659 & 286 & 226 & 147 & $\$ 77.8$ & $\$ 9.8$ & $\$ 42.0$ \\
\hline Colorado & 43 & 17 & 14 & 12 & $\$ 4.7$ & $\$ 0.5$ & $\$ 2.6$ \\
\hline Illinois & 688 & 250 & 271 & 167 & $\$ 70.5$ & $\$ 8.8$ & $\$ 40.3$ \\
\hline Indiana & 167 & 65 & 72 & 30 & $\$ 12.5$ & $\$ 2.9$ & $\$ 6.7$ \\
\hline Kansas & 841 & 334 & 361 & 147 & $\$ 69.9$ & $\$ 8.9$ & $\$ 38.2$ \\
\hline Kentucky & 1,800 & 784 & 717 & 299 & $\$ 145.7$ & $\$ 19.2$ & $\$ 82.7$ \\
\hline Louisiana & 525 & 234 & 170 & 121 & $\$ 51.0$ & $\$ 5.8$ & $\$ 28.6$ \\
\hline Michigan & 18 & 7 & 7 & 4 & $\$ 1.6$ & $\$ 0.2$ & $\$ 1.0$ \\
\hline Mississippi & 2 & 1 & 1 & 0 & $\$ 0.2$ & $\$ 0.0$ & $\$ 0.1$ \\
\hline Montana & 32 & 14 & 10 & 8 & $\$ 2.8$ & $\$ 0.4$ & $\$ 1.6$ \\
\hline Nebraska & 14 & 6 & 6 & 3 & $\$ 1.2$ & $\$ 0.1$ & $\$ 0.6$ \\
\hline Nevada & 1 & 0 & 0 & 0 & $\$ 0.1$ & $\$ 0.0$ & $\$ 0.0$ \\
\hline New Mexico & 80 & 42 & 21 & 17 & $\$ 8.1$ & $\$ 1.4$ & $\$ 4.6$ \\
\hline New York & 450 & 142 & 117 & 191 & $\$ 52.4$ & $\$ 6.4$ & $\$ 28.5$ \\
\hline Ohio & 111 & 54 & 33 & 24 & $\$ 12.9$ & $\$ 1.5$ & $\$ 5.5$ \\
\hline Oklahoma & 137 & 64 & 46 & 27 & $\$ 12.8$ & $\$ 1.4$ & $\$ 6.9$ \\
\hline Pennsylvania & 1,121 & 510 & 325 & 286 & $\$ 131.6$ & $\$ 13.4$ & $\$ 69.1$ \\
\hline Texas & 885 & 367 & 278 & 240 & $\$ 99.8$ & $\$ 12.1$ & $\$ 52.4$ \\
\hline Utah & 7 & 3 & 3 & 2 & $\$ 0.7$ & $\$ 0.1$ & $\$ 0.4$ \\
\hline Virginia & 1 & 1 & 1 & 0 & $\$ 0.1$ & $\$ 0.0$ & $\$ 0.1$ \\
\hline West Virginia & 512 & 269 & 149 & 94 & $\$ 50.0$ & $\$ 5.8$ & $\$ 25.9$ \\
\hline Wyoming & 312 & 172 & 94 & 47 & $\$ 29.5$ & $\$ 4.4$ & $\$ 17.8$ \\
\hline
\end{tabular}

Notes: This table only includes states with documented orphaned oil and gas wells; GDP = gross domestic product.

Source: BW Research. 


\section{APPENDIX F: ABANDONED COAL MINES: STATE- \\ LEVEL ECONOMIC INVESTMENT IMPACTS}

Table F1 provides the sum of economic outputs from investments in environmental remediation of abandoned coal mines located in rural counties.

The total values include the direct, indirect, and induced impacts on jobs, employee compensation, value added, and taxes on production and imports, These impacts are interpreted as impacts per year for five years.

Table F1 | Environmental Remediation of Abandoned Coal Mines in Rural Counties: State-Level Economic Investment Impacts

\begin{tabular}{|c|c|c|c|c|c|c|c|}
\hline $\begin{array}{l}\text { AVERAGE IMPACTS } \\
\text { PER YEAR FOR } 5 \text { YEARS } \\
\text { RURAL }\end{array}$ & $\begin{array}{l}\text { TOTAL } \\
\text { JOBS PER } \\
\text { YEAR }\end{array}$ & $\begin{array}{l}\text { DIRECT } \\
\text { JOBS PER } \\
\text { YEAR }\end{array}$ & $\begin{array}{l}\text { INDIRECT } \\
\text { JOBS PER } \\
\text { YEAR }\end{array}$ & $\begin{array}{l}\text { INDUCED } \\
\text { JOBS PER } \\
\text { YEAR }\end{array}$ & $\begin{array}{l}\text { TOTAL VALUE } \\
\text { ADDED (GDP) PER } \\
\text { YEAR (S, MILLIONS) }\end{array}$ & $\begin{array}{l}\text { TOTAL TAXES ON } \\
\text { PRODUCTION AND } \\
\text { IMPORTS (TOPI) PER } \\
\text { YEAR (S, MILLIONS) }\end{array}$ & $\begin{array}{l}\text { TOTAL EMPLOYEE } \\
\text { COMPENSATION } \\
\text { (EMPLOYEE INCOME) } \\
\text { PER YEAR (S, MILLIONS) }\end{array}$ \\
\hline Alaska & 33 & 17 & 8 & 9 & $\$ 6.7$ & $\$ 0.3$ & $\$ 1.7$ \\
\hline Alabama & 40 & 16 & 9 & 14 & $\$ 7.1$ & $\$ 0.4$ & $\$ 2.4$ \\
\hline Arkansas & 14 & 5 & 5 & 4 & $\$ 2.0$ & $\$ 0.3$ & $\$ 0.8$ \\
\hline Arizona & 1 & 0 & 0 & 0 & $\$ 0.2$ & $\$ 0.0$ & $\$ 0.1$ \\
\hline California & 0 & 0 & 0 & 0 & $\$ 0.0$ & $\$ 0.0$ & $\$ 0.0$ \\
\hline Colorado & 58 & 18 & 19 & 21 & $\$ 8.8$ & $\$ 0.6$ & $\$ 3.7$ \\
\hline Georgia & 0 & 0 & 0 & 0 & $\$ 0.0$ & $\$ 0.0$ & $\$ 0.0$ \\
\hline lowa & 115 & 41 & 26 & 48 & $\$ 19.4$ & $\$ 1.0$ & $\$ 8.1$ \\
\hline Illinois & 124 & 38 & 32 & 55 & $\$ 20.4$ & $\$ 1.6$ & $\$ 8.9$ \\
\hline Indiana & 152 & 50 & 37 & 64 & $\$ 22.5$ & $\$ 1.5$ & $\$ 10.2$ \\
\hline Kansas & 1,411 & 405 & 503 & 503 & $\$ 171.3$ & $\$ 19.9$ & $\$ 86.8$ \\
\hline Kentucky & 984 & 342 & 289 & 352 & $\$ 138.8$ & $\$ 18.2$ & $\$ 64.5$ \\
\hline Louisiana & 0 & 0 & 0 & 0 & $\$ 0.0$ & $\$ 0.0$ & $\$ 0.0$ \\
\hline Maryland & 14 & 5 & 4 & 5 & $\$ 2.3$ & $\$ 0.2$ & $\$ 0.8$ \\
\hline Michigan & 0 & 0 & 0 & 0 & $\$ 0.0$ & $\$ 0.0$ & $\$ 0.0$ \\
\hline Missouri & 79 & 28 & 18 & 33 & $\$ 13.4$ & $\$ 0.7$ & $\$ 5.6$ \\
\hline Mississippi & 0 & 0 & 0 & 0 & $\$ 0.0$ & $\$ 0.0$ & $\$ 0.0$ \\
\hline Montana & 112 & 41 & 28 & 43 & $\$ 17.7$ & $\$ 2.2$ & $\$ 6.2$ \\
\hline North Dakota & 49 & 16 & 12 & 20 & $\$ 7.2$ & $\$ 2.2$ & $\$ 3.9$ \\
\hline New Mexico & 32 & 14 & 7 & 12 & $\$ 5.9$ & $\$ 0.6$ & $\$ 1.9$ \\
\hline Ohio & 698 & 137 & 99 & 462 & $\$ 96.4$ & $\$ 6.1$ & $\$ 37.4$ \\
\hline Oklahoma & 122 & 24 & 14 & 84 & $\$ 16.1$ & $\$ 0.6$ & $\$ 5.2$ \\
\hline Pennsylvania & 1,933 & 628 & 574 & 731 & $\$ 303.8$ & $\$ 17.0$ & $\$ 124.5$ \\
\hline Tennessee & 14 & 4 & 5 & 5 & $\$ 1.9$ & $\$ 0.2$ & $\$ 0.8$ \\
\hline
\end{tabular}




\section{Table F1 | Environmental Remediation of Abandoned Coal Mines in Rural Counties: State-Level Economic Investment}

Impacts (Cont:)

\begin{tabular}{|c|c|c|c|c|c|c|c|}
\hline $\begin{array}{l}\text { AVERAGE IMPACTS } \\
\text { PER YEAR FOR } 5 \text { YEARS } \\
\text { RURAL }\end{array}$ & $\begin{array}{l}\text { TOTAL } \\
\text { JOBS PER } \\
\text { YEAR }\end{array}$ & $\begin{array}{l}\text { DIRECT } \\
\text { JOBS PER } \\
\text { YEAR }\end{array}$ & $\begin{array}{l}\text { INDIRECT } \\
\text { JOBS PER } \\
\text { YEAR }\end{array}$ & $\begin{array}{l}\text { INDUCED } \\
\text { JOBS PER } \\
\text { YEAR }\end{array}$ & $\begin{array}{l}\text { TOTAL VALUE } \\
\text { ADDED (GDP) PER } \\
\text { YEAR (\$, MILLIONS) }\end{array}$ & $\begin{array}{l}\text { TOTAL TAXES ON } \\
\text { PRODUCTION AND } \\
\text { IMPORTS (TOPI) PER } \\
\text { YEAR (S, MILLIONS) }\end{array}$ & $\begin{array}{l}\text { TOTAL EMPLOYEE } \\
\text { COMPENSATION } \\
\text { (EMPLOYEE INCOME) } \\
\text { PER YEAR (S, MILLIONS) }\end{array}$ \\
\hline Texas & 13 & 4 & 4 & 5 & $\$ 2.0$ & $\$ 0.1$ & $\$ 0.8$ \\
\hline Utah & 8 & 3 & 2 & 3 & $\$ 1.3$ & $\$ 0.1$ & $\$ 0.4$ \\
\hline Virginia & 133 & 50 & 37 & 46 & $\$ 22.3$ & $\$ 1.7$ & $\$ 9.1$ \\
\hline West Virginia & 877 & 349 & 199 & 329 & $\$ 146.9$ & $\$ 17.8$ & $\$ 60.8$ \\
\hline Wyoming & 89 & 43 & 17 & 29 & $\$ 18.4$ & $\$ 1.8$ & $\$ 4.9$ \\
\hline
\end{tabular}

Notes: This table only includes states with priority 1 and 2 abandoned coal mines per the eAMLIS database from the Office of Surface Mining Reclamation and Enforcement. Priority 1 and 2 mines are those that pose a threat to the health, safety, and general welfare of people; GDP = gross domestic product.

Source: BW Research.

Table F2 provides the sum of economic outputs from investments in environmental remediation of abandoned coal mines located in both urban and rural counties. The total values include the direct, indirect, and induced impacts on jobs, employee compensation, value added, and taxes on production and imports. These impacts are interpreted as impacts per year for five years.

Table F2 | Environmental Remediation of Abandoned Coal Mines Located in Rural and Urban Counties: State-Level Economic Investment Impacts

\begin{tabular}{|l|c|c|c|c|c|c|c|}
\hline $\begin{array}{l}\text { AVERAGE IMPACTS } \\
\text { PER YEAR FOR 5 YEARS } \\
\text { NATIONAL }\end{array}$ & $\begin{array}{l}\text { TOTAL } \\
\text { JOBS PER } \\
\text { YEAR }\end{array}$ & $\begin{array}{l}\text { DIRECT } \\
\text { JOBS PER } \\
\text { YEAR }\end{array}$ & $\begin{array}{l}\text { INDIRECT } \\
\text { JOBS PER } \\
\text { YEAR }\end{array}$ & $\begin{array}{l}\text { INDUCED } \\
\text { JOBS PER } \\
\text { YEAR }\end{array}$ & $\begin{array}{l}\text { TOTAL VALUE } \\
\text { ADDED (GDP) PER } \\
\text { YEAR (S, MILLIONS) }\end{array}$ & $\begin{array}{l}\text { TOTAL TAXES ON } \\
\text { PRODUCTON AND } \\
\text { IMPORTS (TOPI) PER } \\
\text { YEAR (S, MILLIONS) }\end{array}$ & $\begin{array}{l}\text { TOTAL EMPLOYEE } \\
\text { COMPENSATION } \\
\text { (EMPLOYEE INCOME) } \\
\text { PER YEAR (S, MILLIONS) }\end{array}$ \\
\hline Alaska & 42 & 21 & 10 & 11 & $\$ 8.2$ & $\$ 0.4$ & $\$ 2.2$ \\
\hline Alabama & 381 & 152 & 91 & 138 & $\$ 63.3$ & $\$ 4.1$ & $\$ 22.7$ \\
\hline Arkansas & 21 & 8 & 7 & 6 & $\$ 2.9$ & $\$ 0.5$ & $\$ 1.1$ \\
\hline Arizona & 2 & 1 & 0 & 1 & $\$ 0.3$ & $\$ 0.0$ & $\$ 0.1$ \\
\hline California & 0 & 0 & 0 & 0 & $\$ 0.0$ & $\$ 0.0$ & $\$ 0.0$ \\
\hline Colorado & 115 & 36 & 38 & 42 & $\$ 16.9$ & $\$ 1.4$ & $\$ 7.2$ \\
\hline Georgia & 0 & 0 & 0 & 0 & $\$ 0.0$ & $\$ 0.0$ & $\$ 0.0$ \\
\hline lowa & 119 & 42 & 27 & 50 & $\$ 20.1$ & $\$ 1.0$ & $\$ 8.4$ \\
\hline Illinois & 217 & 65 & 56 & 96 & $\$ 34.8$ & $\$ 3.0$ & $\$ 15.6$ \\
\hline Indiana & 282 & 92 & 69 & 120 & $\$ 40.7$ & $\$ 3.0$ & $\$ 19.0$ \\
\hline Kansas & 1,526 & 437 & 545 & 544 & $\$ 184.6$ & $\$ 21.9$ & $\$ 93.9$ \\
\hline
\end{tabular}


Table F2 | Environmental Remediation of Abandoned Coal Mines Located in Rural and Urban Counties: State-Level Economic Investment Impacts (Cont.)

\begin{tabular}{|c|c|c|c|c|c|c|c|}
\hline $\begin{array}{l}\text { AVERAGE IMPACTS } \\
\text { PER YEAR FOR } 5 \text { YEARS } \\
\text { NATIONAL }\end{array}$ & $\begin{array}{l}\text { TOTAL } \\
\text { JOBS PER } \\
\text { YEAR }\end{array}$ & $\begin{array}{l}\text { DIRECT } \\
\text { JOBS PER } \\
\text { YEAR }\end{array}$ & $\begin{array}{l}\text { INDIRECT } \\
\text { JOBS PER } \\
\text { YEAR }\end{array}$ & $\begin{array}{l}\text { INDUCED } \\
\text { JOBS PER } \\
\text { YEAR }\end{array}$ & $\begin{array}{l}\text { TOTAL VALUE } \\
\text { ADDED (GDP) PER } \\
\text { YEAR (S, MILLIONS) }\end{array}$ & $\begin{array}{l}\text { TOTAL TAXES ON } \\
\text { PRODUCTION AND } \\
\text { IMPORTS (TOPI) PER } \\
\text { YEAR (S, MILLIONS) }\end{array}$ & $\begin{array}{l}\text { TOTAL EMPLOYEE } \\
\text { COMPENSATION } \\
\text { (EMPLOYEE INCOME) } \\
\text { PER YEAR (\$, MILLIONS) }\end{array}$ \\
\hline Kentucky & 1,080 & 375 & 318 & 387 & $\$ 151.6$ & $\$ 20.5$ & $\$ 70.9$ \\
\hline Louisiana & 20 & 7 & 6 & 6 & $\$ 2.9$ & $\$ 0.3$ & $\$ 1.1$ \\
\hline Maryland & 53 & 20 & 14 & 19 & $\$ 8.6$ & $\$ 0.7$ & $\$ 2.9$ \\
\hline Michigan & 6 & 2 & 2 & 3 & $\$ 0.9$ & $\$ 0.1$ & $\$ 0.4$ \\
\hline Missouri & 169 & 60 & 38 & 71 & $\$ 27.7$ & $\$ 1.7$ & $\$ 12.0$ \\
\hline Mississippi & 0 & 0 & 0 & 0 & $\$ 0.0$ & $\$ 0.0$ & $\$ 0.0$ \\
\hline Montana & 330 & 120 & 83 & 127 & $\$ 50.1$ & $\$ 7.9$ & $\$ 18.4$ \\
\hline North Dakota & 61 & 21 & 15 & 26 & $\$ 9.0$ & $\$ 3.0$ & $\$ 5.0$ \\
\hline New Mexico & 46 & 20 & 10 & 16 & $\$ 8.2$ & $\$ 0.9$ & $\$ 2.7$ \\
\hline Ohio & 1,131 & 219 & 161 & 751 & $\$ 153.2$ & $\$ 10.7$ & $\$ 60.0$ \\
\hline Oklahoma & 280 & 54 & 33 & 193 & $\$ 35.8$ & $\$ 1.5$ & $\$ 11.6$ \\
\hline Pennsylvania & 6,771 & 2,159 & 2,030 & 2,582 & $\$ 1,022.4$ & $\$ 66.7$ & $\$ 433.0$ \\
\hline Tennessee & 27 & 8 & 9 & 9 & $\$ 3.6$ & $\$ 0.3$ & $\$ 1.6$ \\
\hline Texas & 14 & 4 & 4 & 5 & $\$ 2.1$ & $\$ 0.1$ & $\$ 0.8$ \\
\hline Utah & 10 & 3 & 3 & 3 & $\$ 1.6$ & $\$ 0.1$ & $\$ 0.5$ \\
\hline Virginia & 147 & 55 & 42 & 51 & $\$ 24.5$ & $\$ 1.9$ & $\$ 10.1$ \\
\hline West Virginia & 1,780 & 700 & 407 & 673 & $\$ 288.7$ & $\$ 42.2$ & $\$ 124.7$ \\
\hline Wyoming & 90 & 44 & 17 & 29 & $\$ 18.5$ & $\$ 1.8$ & $\$ 4.9$ \\
\hline
\end{tabular}

Notes: This table only includes states with priority 1 and 2 abandoned coal mines per the eAMLIS database from the Office of Surface Mining Reclamation and Enforcement. Priority 1 and 2 mines are those that pose a threat to the health, safety, and general welfare of people; GDP = gross domestic product.

Source: BW Research. 


\section{APPENDIX G: TREE RESTORATION ON \\ FEDERAL LANDS: STATE-LEVEL ECONOMIC \\ INVESTMENT IMPACTS}

Table G1 provides the sum of economic outputs from investments in rural tree restoration on federal lands. The total values include the direct, indirect,

and induced impacts on jobs, employee compensation, value added, and taxes on production and imports. These impacts are interpreted as impacts per year for 20 years.

Table G1 | Tree Restoration on Federal Lands in Rural Counties: State-Level Economic Investment Impacts

\begin{tabular}{|c|c|c|c|c|c|c|c|}
\hline $\begin{array}{l}\text { AVERAGE IMPACTS PER } \\
\text { YEAR FOR } 20 \text { YEARS } \\
\text { RURAL }\end{array}$ & $\begin{array}{l}\text { TOTAL } \\
\text { JOBS PER } \\
\text { YEAR }\end{array}$ & $\begin{array}{l}\text { DIRECT } \\
\text { JOBS PER } \\
\text { YEAR }\end{array}$ & $\begin{array}{l}\text { INDIRECT } \\
\text { JOBS PER } \\
\text { YEAR }\end{array}$ & $\begin{array}{l}\text { INDUCED } \\
\text { JOBS PER } \\
\text { YEAR }\end{array}$ & $\begin{array}{l}\text { TOTAL VALUE } \\
\text { ADDED (GDP) PER } \\
\text { YEAR (S, MILLIONS) }\end{array}$ & $\begin{array}{l}\text { TOTAL TAXES ON } \\
\text { PRODUCTION AND } \\
\text { IMPORTS (TOPI) PER } \\
\text { YEAR (S, MILLIONS) }\end{array}$ & $\begin{array}{l}\text { TOTAL EMPLOYEE } \\
\text { COMPENSATION } \\
\text { (EMPLOYEE INCOME) } \\
\text { PER YEAR (\$, MILLIONS) }\end{array}$ \\
\hline Alabama & 30 & 22 & 2 & 6 & $\$ 2.0$ & $\$ 0.0$ & $\$ 1.2$ \\
\hline Arkansas & 181 & 137 & 11 & 33 & $\$ 10.4$ & $\$ 0.3$ & $\$ 6.9$ \\
\hline Arizona & 131 & 91 & 10 & 30 & $\$ 8.7$ & $\$ 0.3$ & $\$ 6.1$ \\
\hline California & 371 & 264 & 25 & 82 & $\$ 30.0$ & $\$ 0.8$ & $\$ 21.3$ \\
\hline Colorado & 1,213 & 890 & 111 & 213 & $\$ 66.1$ & $\$ 1.8$ & $\$ 46.2$ \\
\hline Connecticut & 0 & 0 & 0 & 0 & $\$ 0.0$ & $\$ 0.0$ & $\$ 0.0$ \\
\hline Delaware ${ }^{\mathrm{a}}$ & 0 & 0 & 0 & 0 & $\$ 0.0$ & $\$ 0.0$ & $\$ 0.0$ \\
\hline Florida & 28 & 20 & 2 & 6 & $\$ 1.7$ & $\$ 0.1$ & $\$ 1.2$ \\
\hline Georgia & 36 & 26 & 3 & 7 & $\$ 2.0$ & $\$ 0.1$ & $\$ 1.4$ \\
\hline lowa & 257 & 196 & 11 & 50 & $\$ 15.0$ & $\$ 0.4$ & $\$ 8.4$ \\
\hline Idaho & 643 & 466 & 52 & 125 & $\$ 38.6$ & $\$ 0.9$ & $\$ 24.5$ \\
\hline Illinois & 31 & 22 & 1 & 7 & $\$ 2.0$ & $\$ 0.1$ & $\$ 1.2$ \\
\hline Indiana & 39 & 26 & 2 & 11 & $\$ 2.5$ & $\$ 0.1$ & $\$ 1.3$ \\
\hline Kansas & 7 & 5 & 0 & 1 & $\$ 0.4$ & $\$ 0.0$ & $\$ 0.2$ \\
\hline Kentucky & 57 & 42 & 4 & 11 & $\$ 3.0$ & $\$ 0.1$ & $\$ 2.2$ \\
\hline Louisiana & 44 & 34 & 3 & 8 & $\$ 2.1$ & $\$ 0.1$ & $\$ 1.6$ \\
\hline Maine & 0 & 0 & 0 & 0 & $\$ 0.0$ & $\$ 0.0$ & $\$ 0.0$ \\
\hline Maryland & 4 & 3 & 0 & 1 & $\$ 0.2$ & $\$ 0.0$ & $\$ 0.1$ \\
\hline Massachusetts & 15 & 11 & 1 & 2 & $\$ 0.5$ & $\$ 0.0$ & $\$ 0.4$ \\
\hline Michigan & 255 & 185 & 18 & 52 & $\$ 13.6$ & $\$ 0.4$ & $\$ 9.2$ \\
\hline Minnesota & 178 & 130 & 10 & 38 & $\$ 10.4$ & $\$ 0.3$ & $\$ 6.3$ \\
\hline Missouri & 280 & 210 & 17 & 53 & $\$ 13.9$ & $\$ 0.4$ & $\$ 8.8$ \\
\hline Mississippi & 99 & 74 & 7 & 18 & $\$ 5.1$ & $\$ 0.2$ & $\$ 3.6$ \\
\hline Montana & 926 & 689 & 67 & 170 & $\$ 46.7$ & $\$ 0.8$ & $\$ 32.4$ \\
\hline
\end{tabular}




\begin{tabular}{|c|c|c|c|c|c|c|c|}
\hline $\begin{array}{l}\text { AVERAGE IMPACTS PER } \\
\text { YEAR FOR } 20 \text { YEARS } \\
\text { RURAL }\end{array}$ & $\begin{array}{l}\text { TOTAL } \\
\text { JOBS PER } \\
\text { YEAR }\end{array}$ & $\begin{array}{l}\text { DIRECT } \\
\text { JOBS PER } \\
\text { YEAR }\end{array}$ & $\begin{array}{l}\text { INDIRECT } \\
\text { JOBS PER } \\
\text { YEAR }\end{array}$ & $\begin{array}{l}\text { INDUCED } \\
\text { JOBS PER } \\
\text { YEAR }\end{array}$ & $\begin{array}{l}\text { TOTAL VALUE } \\
\text { ADDED (GDP) PER } \\
\text { YEAR (S, MILLIONS) }\end{array}$ & $\begin{array}{l}\text { TOTAL TAXES ON } \\
\text { PRODUCTION AND } \\
\text { IMPORTS (TOPI) PER } \\
\text { YEAR (S, MILLIONS) }\end{array}$ & $\begin{array}{l}\text { TOTAL EMPLOYEE } \\
\text { COMPENSATION } \\
\text { (EMPLOYEE INCOME) } \\
\text { PER YEAR (S, MILLIONS) }\end{array}$ \\
\hline North Carolina & 50 & 37 & 4 & 9 & $\$ 2.9$ & $\$ 0.1$ & $\$ 2.0$ \\
\hline North Dakota & 19 & 15 & 1 & 4 & $\$ 1.1$ & $\$ 0.0$ & $\$ 0.7$ \\
\hline Nebraska & 7 & 5 & 0 & 1 & $\$ 0.4$ & $\$ 0.0$ & $\$ 0.2$ \\
\hline New Hampshire & 31 & 22 & 3 & 7 & $\$ 1.9$ & $\$ 0.1$ & $\$ 0.9$ \\
\hline New Jersey ${ }^{\mathrm{a}}$ & 0 & 0 & 0 & 0 & $\$ 0.0$ & $\$ 0.0$ & $\$ 0.0$ \\
\hline New Mexico & 513 & 393 & 35 & 85 & $\$ 26.5$ & $\$ 0.7$ & $\$ 18.4$ \\
\hline Nevada & 720 & 615 & 31 & 74 & $\$ 27.0$ & $\$ 0.9$ & $\$ 21.8$ \\
\hline New York & 6 & 5 & 0 & 1 & $\$ 0.4$ & $\$ 0.0$ & $\$ 0.2$ \\
\hline Ohio & 33 & 25 & 2 & 7 & $\$ 1.5$ & $\$ 0.1$ & $\$ 1.0$ \\
\hline Oklahoma & 2 & 1 & 0 & 0 & $\$ 0.1$ & $\$ 0.0$ & $\$ 0.0$ \\
\hline Oregon & 131 & 93 & 10 & 28 & $\$ 8.5$ & $\$ 0.2$ & $\$ 5.9$ \\
\hline Pennsylvania & 74 & 55 & 4 & 15 & $\$ 3.8$ & $\$ 0.1$ & $\$ 2.5$ \\
\hline Rhode Island ${ }^{\mathrm{a}}$ & 0 & 0 & 0 & 0 & $\$ 0.0$ & $\$ 0.0$ & $\$ 0.0$ \\
\hline South Carolina & 22 & 17 & 2 & 4 & $\$ 1.2$ & $\$ 0.0$ & $\$ 0.9$ \\
\hline South Dakota & 70 & 54 & 3 & 12 & $\$ 3.4$ & $\$ 0.1$ & $\$ 2.0$ \\
\hline Tennessee & 47 & 36 & 3 & 8 & $\$ 2.3$ & $\$ 0.1$ & $\$ 1.5$ \\
\hline Texas & 1 & 1 & 0 & 0 & $\$ 0.1$ & $\$ 0.0$ & $\$ 0.1$ \\
\hline Utah & 1,514 & 1,198 & 110 & 207 & $\$ 58.9$ & $\$ 1.5$ & $\$ 46.2$ \\
\hline Virginia & 45 & 36 & 3 & 6 & $\$ 2.0$ & $\$ 0.1$ & $\$ 1.4$ \\
\hline Vermont & 31 & 23 & 3 & 4 & $\$ 1.2$ & $\$ 0.0$ & $\$ 0.8$ \\
\hline Washington & 29 & 22 & 2 & 6 & $\$ 2.1$ & $\$ 0.1$ & $\$ 1.5$ \\
\hline Wisconsin & 121 & 85 & 8 & 27 & $\$ 6.9$ & $\$ 0.2$ & $\$ 4.6$ \\
\hline West Virginia & 99 & 78 & 6 & 14 & $\$ 3.8$ & $\$ 0.1$ & $\$ 3.0$ \\
\hline Wyoming & 862 & 642 & 63 & 158 & $\$ 43.5$ & $\$ 0.8$ & $\$ 30.2$ \\
\hline
\end{tabular}

Notes: Alaska, the District of Columbia, and Hawaii were not included in this analysis due to a lack of available forestry data; GDP = gross domestic product; ${ }^{\mathrm{a}}$. Delaware, New Jersey, and Rhode Island do not have any rural counties as defined by the U.S. Department of Agriculture.

Source: BW Research. 
Tabel G2 provides the sum of economic outputs from investments in national tree restoration on federal lands. The total values include the direct, indirect, and induced impacts on jobs, employee compensation, value added, and taxes on production and imports. These impacts are interpreted as impacts per year for 20 years.

Table G2 | Tree Restoration on Federal Lands in Urban and Rural Counties: State-Level Economic Investment Impacts

\begin{tabular}{|c|c|c|c|c|c|c|c|}
\hline $\begin{array}{l}\text { AVERAGE IMPACTS PER } \\
\text { YEAR FOR } 20 \text { YEARS } \\
\text { NATIONAL }\end{array}$ & $\begin{array}{l}\text { TOTAL } \\
\text { JOBS PER } \\
\text { YEAR }\end{array}$ & $\begin{array}{l}\text { DIRECT } \\
\text { JOBS PER } \\
\text { YEAR }\end{array}$ & $\begin{array}{l}\text { INDIRECT } \\
\text { JOBS PER } \\
\text { YEAR }\end{array}$ & $\begin{array}{l}\text { INDUCED } \\
\text { JOBS PER } \\
\text { YEAR }\end{array}$ & $\begin{array}{l}\text { TOTAL VALUE } \\
\text { ADDED (GDP) PER } \\
\text { YEAR (S, MILLIONS) }\end{array}$ & $\begin{array}{l}\text { TOTAL TAXES ON } \\
\text { PRODUCTION AND } \\
\text { IMPORTS (TOPI) PER } \\
\text { YEAR (S, MILLIONS) }\end{array}$ & $\begin{array}{l}\text { TOTAL EMPLOYEE } \\
\text { COMPENSATION } \\
\text { (EMPLOYEE INCOME) } \\
\text { PER YEAR (S, MILLIONS) }\end{array}$ \\
\hline Alabama & 55 & 40 & 4 & 11 & $\$ 3.5$ & $\$ 0.1$ & $\$ 2.1$ \\
\hline Arkansas & 219 & 167 & 13 & 40 & $\$ 12.5$ & $\$ 0.3$ & $\$ 8.2$ \\
\hline Arizona & 412 & 289 & 31 & 92 & $\$ 26.0$ & $\$ 0.8$ & $\$ 18.4$ \\
\hline California & 526 & 376 & 36 & 114 & $\$ 41.8$ & $\$ 1.2$ & $\$ 29.7$ \\
\hline Colorado & 1,497 & 1,101 & 137 & 260 & $\$ 80.6$ & $\$ 2.1$ & $\$ 56.4$ \\
\hline Connecticut & 0 & 0 & 0 & 0 & $\$ 0.0$ & $\$ 0.0$ & $\$ 0.0$ \\
\hline Delaware & 3 & 2 & 0 & 0 & $\$ 0.1$ & $\$ 0.0$ & $\$ 0.1$ \\
\hline Florida & 171 & 120 & 15 & 36 & $\$ 9.8$ & $\$ 0.3$ & $\$ 7.0$ \\
\hline Georgia & 80 & 58 & 6 & 16 & $\$ 4.3$ & $\$ 0.1$ & $\$ 3.0$ \\
\hline lowa & 329 & 251 & 14 & 64 & $\$ 18.9$ & $\$ 0.5$ & $\$ 10.6$ \\
\hline Idaho & 824 & 599 & 67 & 159 & $\$ 48.7$ & $\$ 1.1$ & $\$ 30.9$ \\
\hline Illinois & 47 & 35 & 2 & 11 & $\$ 3.0$ & $\$ 0.1$ & $\$ 1.8$ \\
\hline Indiana & 55 & 38 & 2 & 16 & $\$ 3.4$ & $\$ 0.1$ & $\$ 1.8$ \\
\hline Kansas & 8 & 6 & 0 & 2 & $\$ 0.5$ & $\$ 0.0$ & $\$ 0.2$ \\
\hline Kentucky & 67 & 50 & 4 & 12 & $\$ 3.5$ & $\$ 0.1$ & $\$ 2.6$ \\
\hline Louisiana & 77 & 59 & 5 & 13 & $\$ 3.5$ & $\$ 0.1$ & $\$ 2.7$ \\
\hline Maine & 9 & 8 & 0 & 1 & $\$ 0.5$ & $\$ 0.0$ & $\$ 0.3$ \\
\hline Maryland & 16 & 13 & 1 & 2 & $\$ 0.7$ & $\$ 0.0$ & $\$ 0.5$ \\
\hline Massachusetts & 27 & 21 & 3 & 4 & $\$ 0.9$ & $\$ 0.0$ & $\$ 0.8$ \\
\hline Michigan & 257 & 187 & 18 & 52 & $\$ 13.8$ & $\$ 0.4$ & $\$ 9.3$ \\
\hline Minnesota & 281 & 205 & 17 & 59 & $\$ 16.0$ & $\$ 0.5$ & $\$ 9.7$ \\
\hline Missouri & 303 & 227 & 19 & 57 & $\$ 15.0$ & $\$ 0.4$ & $\$ 9.5$ \\
\hline Mississippi & 149 & 112 & 11 & 27 & $\$ 7.6$ & $\$ 0.2$ & $\$ 5.3$ \\
\hline Montana & 995 & 741 & 72 & 182 & $\$ 50.0$ & $\$ 0.9$ & $\$ 34.7$ \\
\hline North Carolina & 69 & 52 & 5 & 12 & $\$ 3.9$ & $\$ 0.1$ & $\$ 2.7$ \\
\hline North Dakota & 19 & 15 & 1 & 4 & $\$ 1.1$ & $\$ 0.0$ & $\$ 0.7$ \\
\hline
\end{tabular}




\begin{tabular}{|c|c|c|c|c|c|c|c|}
\hline $\begin{array}{l}\text { AVERAGE IMPACTS PER } \\
\text { YEAR FOR 2O YEARS } \\
\text { NATIONAL }\end{array}$ & $\begin{array}{l}\text { TOTAL } \\
\text { JOBS PER } \\
\text { YEAR }\end{array}$ & $\begin{array}{l}\text { DIRECT } \\
\text { JOBS PER } \\
\text { YEAR }\end{array}$ & $\begin{array}{l}\text { INDIRECT } \\
\text { JOBS PER } \\
\text { YEAR }\end{array}$ & $\begin{array}{l}\text { INDUCED } \\
\text { JOBS PER } \\
\text { YEAR }\end{array}$ & $\begin{array}{l}\text { TOTAL VALUE } \\
\text { ADDED (GDP) PER } \\
\text { YEAR (S, MILLIONS) }\end{array}$ & $\begin{array}{l}\text { TOTAL TAXES ON } \\
\text { PRODUCTION AND } \\
\text { IMPORTS (TOPI) PER } \\
\text { YEAR (S, MILLIONS) }\end{array}$ & $\begin{array}{l}\text { TOTAL EMPLOYEE } \\
\text { COMPENSATION } \\
\text { (EMPLOYEE INCOME) } \\
\text { PER YEAR (S, MILLIONS) }\end{array}$ \\
\hline Nebraska & 9 & 7 & 0 & 2 & $\$ 0.5$ & $\$ 0.0$ & $\$ 0.3$ \\
\hline New Hampshire & 31 & 22 & 3 & 7 & $\$ 1.9$ & $\$ 0.1$ & $\$ 0.9$ \\
\hline New Jersey & 18 & 14 & 1 & 3 & $\$ 1.0$ & $\$ 0.0$ & $\$ 0.8$ \\
\hline New Mexico & 617 & 473 & 42 & 102 & $\$ 31.5$ & $\$ 0.9$ & $\$ 21.9$ \\
\hline Nevada & 856 & 732 & 37 & 87 & $\$ 31.7$ & $\$ 1.1$ & $\$ 25.6$ \\
\hline New York & 24 & 19 & 1 & 4 & $\$ 1.4$ & $\$ 0.0$ & $\$ 0.9$ \\
\hline Ohio & 69 & 52 & 4 & 14 & $\$ 3.1$ & $\$ 0.1$ & $\$ 2.1$ \\
\hline Oklahoma & 2 & 2 & 0 & 0 & $\$ 0.1$ & $\$ 0.0$ & $\$ 0.1$ \\
\hline Oregon & 166 & 119 & 13 & 35 & $\$ 10.6$ & $\$ 0.2$ & $\$ 7.4$ \\
\hline Pennsylvania & 84 & 62 & 5 & 17 & $\$ 4.3$ & $\$ 0.1$ & $\$ 2.8$ \\
\hline Rhode Island & 0 & 0 & 0 & 0 & $\$ 0.0$ & $\$ 0.0$ & $\$ 0.0$ \\
\hline South Carolina & 49 & 37 & 4 & 9 & $\$ 2.6$ & $\$ 0.1$ & $\$ 1.9$ \\
\hline South Dakota & 180 & 141 & 9 & 31 & $\$ 8.5$ & $\$ 0.2$ & $\$ 4.9$ \\
\hline Tennessee & 96 & 75 & 6 & 16 & $\$ 4.5$ & $\$ 0.1$ & $\$ 2.9$ \\
\hline Texas & 4 & 3 & 0 & 1 & $\$ 0.2$ & $\$ 0.0$ & $\$ 0.1$ \\
\hline Utah & 1,712 & 1,356 & 124 & 232 & $\$ 66.1$ & $\$ 1.7$ & $\$ 51.9$ \\
\hline Virginia & 96 & 77 & 6 & 12 & $\$ 4.1$ & $\$ 0.1$ & $\$ 3.0$ \\
\hline Vermont & 32 & 24 & 3 & 5 & $\$ 1.2$ & $\$ 0.0$ & $\$ 0.8$ \\
\hline Washington & 76 & 57 & 5 & 14 & $\$ 5.2$ & $\$ 0.2$ & $\$ 3.8$ \\
\hline Wisconsin & 134 & 95 & 9 & 30 & $\$ 7.6$ & $\$ 0.2$ & $\$ 5.1$ \\
\hline West Virginia & 114 & 91 & 7 & 16 & $\$ 4.4$ & $\$ 0.1$ & $\$ 3.4$ \\
\hline Wyoming & 879 & 654 & 64 & 161 & $\$ 44.3$ & $\$ 0.8$ & $\$ 30.7$ \\
\hline
\end{tabular}

Notes: Alaska, the District of Columbia, and Hawaii were not included in this analysis due to a lack of available forestry data; GDP = gross domestic product.

Source: BW Research. 


\section{APPENDIX H: TREE RESTORATION ON NON- \\ FEDERAL LANDS: STATE-LEVEL ECONOMIC \\ INVESTMENT IMPACTS}

Table $\mathrm{H} 1$ provides the sum of economic outputs from investments in rural tree restoration on non-federal lands and agroforestry. The total values

include the direct, indirect, and induced impacts on jobs, employee compen- sation, value added, and taxes on production and imports. These impacts are interpreted as impacts per year for 20 years.

Table H1 | Tree Restoration on Non-federal Lands in Rural Counties: State-Level Economic Investment Impacts

\begin{tabular}{|c|c|c|c|c|c|c|c|}
\hline $\begin{array}{l}\text { AVERAGE IMPACTS PER } \\
\text { YEAR FOR } 20 \text { YEARS } \\
\text { RURAL }\end{array}$ & $\begin{array}{l}\text { TOTAL } \\
\text { JOBS PER } \\
\text { YEAR }\end{array}$ & $\begin{array}{l}\text { DIRECT } \\
\text { JOBS PER } \\
\text { YEAR }\end{array}$ & $\begin{array}{l}\text { INDIRECT } \\
\text { JOBS PER } \\
\text { YEAR }\end{array}$ & $\begin{array}{l}\text { INDUCED } \\
\text { JOBS PER } \\
\text { YEAR }\end{array}$ & $\begin{array}{l}\text { TOTAL VALUE } \\
\text { ADDED (GDP) PER } \\
\text { YEAR (\$, MILLIONS) }\end{array}$ & $\begin{array}{l}\text { TOTAL TAXES ON } \\
\text { PRODUCTION AND } \\
\text { IMPORTS (TOPI) PER } \\
\text { YEAR (S, MILLIONS) }\end{array}$ & $\begin{array}{l}\text { TOTAL EMPLOYEE } \\
\text { COMPENSATION } \\
\text { (EMPLOYEE INCOME) } \\
\text { PER YEAR (\$, MILLIONS) }\end{array}$ \\
\hline Alabama & 1,332 & 957 & 106 & 270 & $\$ 84.9$ & $\$ 3.4$ & $\$ 53.4$ \\
\hline Arkansas & 2,119 & 1,616 & 126 & 376 & $\$ 118.3$ & $\$ 8.1$ & $\$ 83.5$ \\
\hline Arizona & 373 & 260 & 30 & 84 & $\$ 24.1$ & $\$ 1.4$ & $\$ 17.9$ \\
\hline California & 547 & 390 & 39 & 118 & $\$ 43.1$ & $\$ 2.5$ & $\$ 32.4$ \\
\hline Colorado & 1,733 & 1,284 & 152 & 297 & $\$ 92.3$ & $\$ 4.5$ & $\$ 68.3$ \\
\hline Connecticut & 65 & 50 & 4 & 11 & $\$ 3.6$ & $\$ 0.2$ & $\$ 2.1$ \\
\hline Delaware $^{a}$ & 0 & 0 & 0 & 0 & $\$ 0.0$ & $\$ 0.0$ & $\$ 0.0$ \\
\hline Florida & 864 & 607 & 74 & 184 & $\$ 51.0$ & $\$ 2.9$ & $\$ 39.0$ \\
\hline Georgia & 1,554 & 1,137 & 113 & 305 & $\$ 85.5$ & $\$ 4.4$ & $\$ 63.0$ \\
\hline lowa & 2,350 & 1,797 & 105 & 447 & $\$ 133.3$ & $\$ 6.9$ & $\$ 79.1$ \\
\hline Idaho & 1,290 & 939 & 105 & 245 & $\$ 75.6$ & $\$ 3.9$ & $\$ 50.8$ \\
\hline Illinois & 2,133 & 1,556 & 103 & 474 & $\$ 137.1$ & $\$ 8.4$ & $\$ 84.5$ \\
\hline Indiana & 1,821 & 1,232 & 82 & 508 & $\$ 112.3$ & $\$ 7.2$ & $\$ 60.8$ \\
\hline Kansas & 1,223 & 903 & 67 & 253 & $\$ 77.4$ & $\$ 3.9$ & $\$ 40.3$ \\
\hline Kentucky & 2,077 & 1,566 & 133 & 378 & $\$ 106.9$ & $\$ 5.0$ & $\$ 86.0$ \\
\hline Louisiana & 1,215 & 928 & 87 & 201 & $\$ 55.1$ & $\$ 2.9$ & $\$ 44.8$ \\
\hline Maine & 66 & 52 & 3 & 11 & $\$ 3.4$ & $\$ 0.2$ & $\$ 2.4$ \\
\hline Maryland & 192 & 157 & 10 & 25 & $\$ 8.6$ & $\$ 0.5$ & $\$ 6.6$ \\
\hline Massachusetts & 2,077 & 1,569 & 198 & 310 & $\$ 70.0$ & $\$ 4.4$ & $\$ 62.1$ \\
\hline Michigan & 3,293 & 2,400 & 241 & 652 & $\$ 172.5$ & $\$ 9.2$ & $\$ 122.4$ \\
\hline Minnesota & 2,471 & 1,805 & 146 & 520 & $\$ 141.2$ & $\$ 7.6$ & $\$ 89.5$ \\
\hline Missouri & 8,334 & 6,297 & 507 & 1,531 & $\$ 399.9$ & $\$ 19.8$ & $\$ 273.4$ \\
\hline Mississippi & 2,004 & 1,511 & 140 & 353 & $\$ 101.6$ & $\$ 5.6$ & $\$ 75.9$ \\
\hline
\end{tabular}




\begin{tabular}{|c|c|c|c|c|c|c|c|}
\hline $\begin{array}{l}\text { AVERAGE IMPACTS PER } \\
\text { YEAR FOR } 20 \text { YEARS } \\
\text { RURAL }\end{array}$ & $\begin{array}{l}\text { TOTAL } \\
\text { JOBS PER } \\
\text { YEAR }\end{array}$ & $\begin{array}{l}\text { DIRECT } \\
\text { JOBS PER } \\
\text { YEAR }\end{array}$ & $\begin{array}{l}\text { INDIRECT } \\
\text { JOBS PER } \\
\text { YEAR }\end{array}$ & $\begin{array}{l}\text { INDUCED } \\
\text { JOBS PER } \\
\text { YEAR }\end{array}$ & $\begin{array}{l}\text { TOTAL VALUE } \\
\text { ADDED (GDP) PER } \\
\text { YEAR (S, MILLIONS) }\end{array}$ & $\begin{array}{l}\text { TOTAL TAXES ON } \\
\text { PRODUCTION AND } \\
\text { IMPORTS (TOPI) PER } \\
\text { YEAR (S, MILLIONS) }\end{array}$ & $\begin{array}{l}\text { TOTAL EMPLOYEE } \\
\text { COMPENSATION } \\
\text { (EMPLOYEE INCOME) } \\
\text { PER YEAR (S, MILLIONS) }\end{array}$ \\
\hline Montana & 2,703 & 2,031 & 192 & 480 & $\$ 132.1$ & $\$ 5.1$ & $\$ 98.5$ \\
\hline North Carolina & 923 & 689 & 71 & 163 & $\$ 51.8$ & $\$ 2.5$ & $\$ 38.4$ \\
\hline North Dakota & 1,907 & 1,466 & 80 & 360 & $\$ 107.8$ & $\$ 3.5$ & $\$ 70.8$ \\
\hline Nebraska & 2,675 & 2,084 & 132 & 459 & $\$ 140.8$ & $\$ 6.8$ & $\$ 96.0$ \\
\hline New Hampshire & 348 & 243 & 29 & 76 & $\$ 21.3$ & $\$ 1.0$ & $\$ 9.9$ \\
\hline New Jersey ${ }^{\mathrm{a}}$ & 0 & 0 & 0 & 0 & $\$ 0.0$ & $\$ 0.0$ & $\$ 0.0$ \\
\hline New Mexico & 1,148 & 881 & 81 & 186 & $\$ 57.8$ & $\$ 2.7$ & $\$ 42.5$ \\
\hline Nevada & 487 & 418 & 22 & 48 & $\$ 17.4$ & $\$ 1.4$ & $\$ 15.0$ \\
\hline New York & 2,163 & 1,713 & 115 & 335 & $\$ 125.3$ & $\$ 8.1$ & $\$ 88.5$ \\
\hline Ohio & 4,341 & 3,251 & 236 & 854 & $\$ 193.1$ & $\$ 12.1$ & $\$ 137.6$ \\
\hline Oklahoma & 1,075 & 847 & 84 & 145 & $\$ 47.1$ & $\$ 2.3$ & $\$ 30.0$ \\
\hline Oregon & 496 & 358 & 37 & 102 & $\$ 31.1$ & $\$ 1.6$ & $\$ 23.3$ \\
\hline Pennsylvania & 2,560 & 1,907 & 138 & 515 & $\$ 126.6$ & $\$ 7.2$ & $\$ 89.2$ \\
\hline Rhode Island ${ }^{\mathrm{a}}$ & 0 & 0 & 0 & 0 & $\$ 0.0$ & $\$ 0.0$ & $\$ 0.0$ \\
\hline South Carolina & 490 & 370 & 35 & 85 & $\$ 25.7$ & $\$ 1.4$ & $\$ 20.0$ \\
\hline South Dakota & 3,342 & 2,615 & 157 & 570 & $\$ 157.8$ & $\$ 11.3$ & $\$ 97.3$ \\
\hline Tennessee & 1,827 & 1,419 & 111 & 297 & $\$ 86.2$ & $\$ 5.5$ & $\$ 59.5$ \\
\hline Texas & 1,851 & 1,375 & 159 & 317 & $\$ 89.7$ & $\$ 3.8$ & $\$ 70.3$ \\
\hline Utah & 780 & 619 & 57 & 103 & $\$ 29.5$ & $\$ 1.6$ & $\$ 24.5$ \\
\hline Virginia & 1,021 & 829 & 61 & 130 & $\$ 43.8$ & $\$ 2.7$ & $\$ 33.9$ \\
\hline Vermont & 812 & 623 & 72 & 116 & $\$ 29.9$ & $\$ 1.9$ & $\$ 20.8$ \\
\hline Washington & 345 & 260 & 20 & 64 & $\$ 23.5$ & $\$ 1.6$ & $\$ 18.8$ \\
\hline Wisconsin & 3,072 & 2,189 & 203 & 680 & $\$ 170.3$ & $\$ 8.6$ & $\$ 122.1$ \\
\hline West Virginia & 1,604 & 1,284 & 100 & 221 & $\$ 60.6$ & $\$ 4.2$ & $\$ 50.5$ \\
\hline Wyoming & 1,060 & 796 & 76 & 188 & $\$ 51.9$ & $\$ 2.0$ & $\$ 38.6$ \\
\hline
\end{tabular}

Notes: Alaska, the District of Columbia, and Hawaii were not included in this analysis due to a lack of available forestry data; GDP = gross domestic product; a. Delaware, New Jersey, and Rhode Island do not have any rural counties as defined by the U.S. Department of Agriculture.

Source: BW Research. 
Table $\mathrm{H} 2$ provides the sum of economic outputs from investments in national tree restoration on non-federal lands and agroforestry. The total values include the direct, indirect, and induced impacts on jobs, employee compen- sation, value added, and taxes on production and imports. These impacts are interpreted as impacts per year for 20 years.

Table H2 | Tree Restoration on Non-federal Lands in Rural and Urban Counties: State-Level Economic Investment Impacts

\begin{tabular}{|c|c|c|c|c|c|c|c|}
\hline $\begin{array}{l}\text { AVERAGE IMPACTS PER } \\
\text { YEAR FOR } 20 \text { YEARS } \\
\text { NATIONAL }\end{array}$ & $\begin{array}{l}\text { TOTAL } \\
\text { JOBS PER } \\
\text { YEAR }\end{array}$ & $\begin{array}{l}\text { DIRECT } \\
\text { JOBS PER } \\
\text { YEAR }\end{array}$ & $\begin{array}{l}\text { INDIRECT } \\
\text { JOBS PER } \\
\text { YEAR }\end{array}$ & $\begin{array}{l}\text { INDUCED } \\
\text { JOBS PER } \\
\text { YEAR }\end{array}$ & $\begin{array}{l}\text { TOTAL VALUE } \\
\text { ADDED (GDP) PER } \\
\text { YEAR (S, MILLIONS) }\end{array}$ & $\begin{array}{l}\text { TOTAL TAXES ON } \\
\text { PRODUCTION AND } \\
\text { IMPORTS (TOPI) PER } \\
\text { YEAR (S, MILLIONS) }\end{array}$ & $\begin{array}{l}\text { TOTAL EMPLOYEE } \\
\text { COMPENSATION } \\
\text { (EMPLOYEE INCOME) } \\
\text { PER YEAR (S, MILLIONS) }\end{array}$ \\
\hline Alabama & 2,018 & 1,445 & 166 & 407 & $\$ 127.9$ & $\$ 5.1$ & $\$ 80.0$ \\
\hline Arkansas & 2,630 & 2,003 & 160 & 467 & $\$ 146.7$ & $\$ 10.0$ & $\$ 103.0$ \\
\hline Arizona & 715 & 497 & 57 & 161 & $\$ 45.9$ & $\$ 2.7$ & $\$ 33.9$ \\
\hline California & 974 & 694 & 71 & 209 & $\$ 76.6$ & $\$ 4.3$ & $\$ 57.1$ \\
\hline Colorado & 1,997 & 1,476 & 178 & 342 & $\$ 106.1$ & $\$ 5.2$ & $\$ 78.4$ \\
\hline Connecticut & 244 & 188 & 15 & 41 & $\$ 13.4$ & $\$ 0.8$ & $\$ 7.8$ \\
\hline Delaware & 111 & 89 & 5 & 17 & $\$ 5.8$ & $\$ 0.2$ & $\$ 4.2$ \\
\hline Florida & 2,023 & 1,413 & 181 & 429 & $\$ 118.9$ & $\$ 6.6$ & $\$ 89.6$ \\
\hline Georgia & 2,399 & 1,749 & 179 & 470 & $\$ 131.6$ & $\$ 6.8$ & $\$ 96.2$ \\
\hline lowa & 2,890 & 2,209 & 131 & 550 & $\$ 163.9$ & $\$ 8.4$ & $\$ 96.8$ \\
\hline Idaho & 1,504 & 1,094 & 124 & 286 & $\$ 88.0$ & $\$ 4.6$ & $\$ 59.0$ \\
\hline Illinois & 2,705 & 1,973 & 133 & 600 & $\$ 173.6$ & $\$ 10.6$ & $\$ 106.7$ \\
\hline Indiana & 2,987 & 2,018 & 137 & 832 & $\$ 184.1$ & $\$ 11.7$ & $\$ 98.8$ \\
\hline Kansas & 1,490 & 1,099 & 84 & 307 & $\$ 94.1$ & $\$ 4.7$ & $\$ 48.9$ \\
\hline Kentucky & 2,453 & 1,846 & 160 & 446 & $\$ 126.3$ & $\$ 5.8$ & $\$ 100.9$ \\
\hline Louisiana & 1,911 & 1,457 & 140 & 315 & $\$ 86.4$ & $\$ 4.6$ & $\$ 69.8$ \\
\hline Maine & 400 & 316 & 20 & 64 & $\$ 20.6$ & $\$ 1.0$ & $\$ 14.1$ \\
\hline Maryland & 703 & 570 & 41 & 92 & $\$ 31.7$ & $\$ 1.9$ & $\$ 23.7$ \\
\hline Massachusetts & 2,568 & 1,938 & 247 & 383 & $\$ 86.4$ & $\$ 5.4$ & $\$ 76.4$ \\
\hline Michigan & 4,271 & 3,109 & 317 & 845 & $\$ 223.2$ & $\$ 11.8$ & $\$ 157.8$ \\
\hline Minnesota & 3,369 & 2,458 & 204 & 707 & $\$ 192.0$ & $\$ 10.3$ & $\$ 121.3$ \\
\hline Missouri & 9,675 & 7,300 & 597 & 1,778 & $\$ 464.4$ & $\$ 22.8$ & $\$ 315.8$ \\
\hline Mississippi & 2,425 & 1,825 & 173 & 427 & $\$ 122.8$ & $\$ 6.8$ & $\$ 91.3$ \\
\hline Montana & 2,845 & 2,136 & 204 & 505 & $\$ 139.0$ & $\$ 5.3$ & $\$ 103.5$ \\
\hline North Carolina & 1,533 & 1,142 & 122 & 270 & $\$ 85.7$ & $\$ 4.1$ & $\$ 63.0$ \\
\hline North Dakota & 1,998 & 1,536 & 85 & 377 & $\$ 113.0$ & $\$ 3.6$ & $\$ 74.1$ \\
\hline Nebraska & 2,842 & 2,213 & 141 & 487 & $\$ 149.5$ & $\$ 7.2$ & $\$ 101.9$ \\
\hline
\end{tabular}


Table H2 | Tree Restoration on Non-federal Lands in Rural and Urban Counties: State-Level Economic Investment Impacts (Cont:)

\begin{tabular}{|c|c|c|c|c|c|c|c|}
\hline $\begin{array}{l}\text { AVERAGE IMPACTS PER } \\
\text { YEAR FOR } 20 \text { YEARS } \\
\text { NATIONAL }\end{array}$ & $\begin{array}{l}\text { TOTAL } \\
\text { JOBS PER } \\
\text { YEAR }\end{array}$ & $\begin{array}{l}\text { DIRECT } \\
\text { JOBS PER } \\
\text { YEAR }\end{array}$ & $\begin{array}{l}\text { INDIRECT } \\
\text { JOBS PER } \\
\text { YEAR }\end{array}$ & $\begin{array}{l}\text { INDUCED } \\
\text { JOBS PER } \\
\text { YEAR }\end{array}$ & $\begin{array}{l}\text { TOTAL VALUE } \\
\text { ADDED (GDP) PER } \\
\text { YEAR (S, MILLIONS) }\end{array}$ & $\begin{array}{l}\text { TOTAL TAXES ON } \\
\text { PRODUCTION AND } \\
\text { IMPORTS (TOPI) PER } \\
\text { YEAR (S, MILLIONS) }\end{array}$ & $\begin{array}{l}\text { TOTAL EMPLOYEE } \\
\text { COMPENSATION } \\
\text { (EMPLOYEE INCOME) } \\
\text { PER YEAR (S, MILLIONS) }\end{array}$ \\
\hline New Hampshire & 435 & 303 & 37 & 95 & $\$ 26.6$ & $\$ 1.3$ & $\$ 12.4$ \\
\hline New Jersey & 411 & 318 & 22 & 70 & $\$ 23.8$ & $\$ 1.8$ & $\$ 20.2$ \\
\hline New Mexico & 1,342 & 1,029 & 96 & 217 & $\$ 67.5$ & $\$ 3.1$ & $\$ 49.5$ \\
\hline Nevada & 531 & 456 & 24 & 52 & $\$ 19.0$ & $\$ 1.5$ & $\$ 16.4$ \\
\hline New York & 3,207 & 2,533 & 176 & 497 & $\$ 185.8$ & $\$ 11.8$ & $\$ 130.3$ \\
\hline Ohio & 5,996 & 4,483 & 331 & 1,183 & $\$ 267.5$ & $\$ 16.6$ & $\$ 188.7$ \\
\hline Oklahoma & 1,179 & 927 & 94 & 158 & $\$ 51.5$ & $\$ 2.5$ & $\$ 32.8$ \\
\hline Oregon & 620 & 445 & 47 & 127 & $\$ 38.8$ & $\$ 2.0$ & $\$ 28.9$ \\
\hline Pennsylvania & 4,252 & 3,155 & 239 & 858 & $\$ 210.8$ & $\$ 11.8$ & $\$ 146.4$ \\
\hline Rhode Island & 96 & 88 & 4 & 4 & $\$ 1.8$ & $\$ 0.3$ & $\$ 2.0$ \\
\hline South Carolina & 1,014 & 764 & 76 & 175 & $\$ 53.0$ & $\$ 2.9$ & $\$ 40.8$ \\
\hline South Dakota & 3,499 & 2,737 & 165 & 597 & $\$ 165.2$ & $\$ 11.8$ & $\$ 101.7$ \\
\hline Tennessee & 2,636 & 2,042 & 165 & 428 & $\$ 124.4$ & $\$ 7.9$ & $\$ 85.1$ \\
\hline Texas & 2,131 & 1,578 & 189 & 365 & $\$ 103.2$ & $\$ 4.4$ & $\$ 80.6$ \\
\hline Utah & 975 & 773 & 73 & 129 & $\$ 36.8$ & $\$ 2.0$ & $\$ 30.5$ \\
\hline Virginia & 1,635 & 1,323 & 103 & 209 & $\$ 70.3$ & $\$ 4.3$ & $\$ 53.8$ \\
\hline Vermont & 908 & 697 & 82 & 129 & $\$ 33.5$ & $\$ 2.1$ & $\$ 23.3$ \\
\hline Washington & 541 & 406 & 34 & 101 & $\$ 37.0$ & $\$ 2.5$ & $\$ 29.1$ \\
\hline Wisconsin & 3,860 & 2,747 & 259 & 854 & $\$ 213.8$ & $\$ 10.8$ & $\$ 152.5$ \\
\hline West Virginia & 2,260 & 1,805 & 144 & 311 & $\$ 85.4$ & $\$ 5.8$ & $\$ 70.5$ \\
\hline Wyoming & 1,086 & 814 & 78 & 193 & $\$ 53.1$ & $\$ 2.0$ & $\$ 39.5$ \\
\hline
\end{tabular}

Notes: Alaska, the District of Columbia, and Hawaii were not included in this analysis due to a lack of available forestry data; GDP = gross domestic product.

Source: BW Research. 


\section{APPENDIX I: WILDFIRE RISK \\ MANAGEMENT: STATE-LEVEL \\ ECONOMIC INVESTMENT IMPACTS}

Table 11 provides the sum of economic outputs from investments in rural wildfire risk management and its downstream impacts. The total values

include the direct, indirect, and induced impacts on jobs, employee compen- sation, value added, and taxes on production and imports. These impacts are interpreted as impacts per year for $\mathbf{2 0}$ years.

Table I1 | Wildfire Risk Management in Rural Counties: State-Level Economic Investment Impacts

\begin{tabular}{|c|c|c|c|c|c|c|c|}
\hline $\begin{array}{l}\text { AVERAGE IMPACTS PER } \\
\text { YEAR FOR } 20 \text { YEARS } \\
\text { RURAL }\end{array}$ & $\begin{array}{l}\text { TOTAL } \\
\text { JOBS PER } \\
\text { YEAR }\end{array}$ & $\begin{array}{l}\text { DIRECT } \\
\text { JOBS PER } \\
\text { YEAR }\end{array}$ & $\begin{array}{l}\text { INDIRECT } \\
\text { JOBS PER } \\
\text { YEAR }\end{array}$ & $\begin{array}{l}\text { INDUCED } \\
\text { JOBS PER } \\
\text { YEAR }\end{array}$ & $\begin{array}{l}\text { TOTAL VALUE } \\
\text { ADDED (GDP) PER } \\
\text { YEAR (S, MILLIONS) }\end{array}$ & $\begin{array}{l}\text { TOTAL TAXES ON } \\
\text { PRODUCTION AND } \\
\text { IMPORTS (TOPI) PER } \\
\text { YEAR (S, MILLIONS) }\end{array}$ & $\begin{array}{l}\text { TOTAL EMPLOYEE } \\
\text { COMPENSATION } \\
\text { (EMPLOYEE INCOME) } \\
\text { PER YEAR (S, MILLIONS) }\end{array}$ \\
\hline Alabama & 34 & 18 & 10 & 6 & $\$ 2.2$ & $\$ 0.1$ & $\$ 1.6$ \\
\hline Arkansas & 1 & 0 & 0 & 0 & $\$ 0.0$ & $\$ 0.0$ & $\$ 0.0$ \\
\hline Arizona & 434 & 224 & 123 & 87 & $\$ 27.7$ & $\$ 1.8$ & $\$ 22.4$ \\
\hline California & 14,132 & 7,264 & 4,029 & 2,840 & $\$ 1,207,6$ & $\$ 74.7$ & $\$ 972.4$ \\
\hline Colorado & 2,803 & 1,509 & 855 & 440 & $\$ 156.3$ & $\$ 8.4$ & $\$ 124.6$ \\
\hline Connecticut & 0 & 0 & 0 & 0 & $\$ 0.0$ & $\$ 0.0$ & $\$ 0.0$ \\
\hline Delaware & 0 & 0 & 0 & 0 & $\$ 0.0$ & $\$ 0.0$ & $\$ 0.0$ \\
\hline Florida & 189 & 96 & 54 & 38 & $\$ 12.0$ & $\$ 0.8$ & $\$ 9.8$ \\
\hline Georgia & 319 & 171 & 84 & 63 & $\$ 21.4$ & $\$ 1.2$ & $\$ 16.5$ \\
\hline lowa & 0 & 0 & 0 & 0 & $\$ 0.0$ & $\$ 0.0$ & $\$ 0.0$ \\
\hline Idaho & 4,103 & 2,210 & 1,105 & 788 & $\$ 272.5$ & $\$ 14.5$ & $\$ 198.1$ \\
\hline Illinois & 0 & 0 & 0 & 0 & $\$ 0.0$ & $\$ 0.0$ & $\$ 0.0$ \\
\hline Indiana & 0 & 0 & 0 & 0 & $\$ 0.0$ & $\$ 0.0$ & $\$ 0.0$ \\
\hline Kansas & 50 & 29 & 13 & 8 & $\$ 3.1$ & $\$ 0.2$ & $\$ 1.8$ \\
\hline Kentucky & 189 & 114 & 43 & 33 & $\$ 10.5$ & $\$ 0.6$ & $\$ 7.9$ \\
\hline Louisiana & 55 & 33 & 13 & 9 & $\$ 2.9$ & $\$ 0.2$ & $\$ 2.3$ \\
\hline Maine & 0 & 0 & 0 & 0 & $\$ 0.0$ & $\$ 0.0$ & $\$ 0.0$ \\
\hline Maryland & 24 & 16 & 5 & 3 & $\$ 1.3$ & $\$ 0.1$ & $\$ 1.0$ \\
\hline Massachusetts & 0 & 0 & 0 & 0 & $\$ 0.0$ & $\$ 0.0$ & $\$ 0.0$ \\
\hline Michigan & 27 & 15 & 7 & 5 & $\$ 1.6$ & $\$ 0.1$ & $\$ 1.2$ \\
\hline Minnesota & 776 & 412 & 214 & 150 & $\$ 46.7$ & $\$ 2.9$ & $\$ 35.9$ \\
\hline Missouri & 1 & 1 & 0 & 0 & $\$ 0.1$ & $\$ 0.0$ & $\$ 0.1$ \\
\hline Mississippi & 135 & 75 & 38 & 22 & $\$ 7.8$ & $\$ 0.5$ & $\$ 5.5$ \\
\hline Montana & 3,432 & 1,962 & 893 & 577 & $\$ 190.3$ & $\$ 7.9$ & $\$ 135.9$ \\
\hline
\end{tabular}




\begin{tabular}{|c|c|c|c|c|c|c|c|}
\hline $\begin{array}{l}\text { AVERAGE IMPACTS PER } \\
\text { YEAR FOR } 20 \text { YEARS } \\
\text { RURAL }\end{array}$ & $\begin{array}{l}\text { TOTAL } \\
\text { JOBS PER } \\
\text { YEAR }\end{array}$ & $\begin{array}{l}\text { DIRECT } \\
\text { JOBS PER } \\
\text { YEAR }\end{array}$ & $\begin{array}{l}\text { INDIRECT } \\
\text { JOBS PER } \\
\text { YEAR }\end{array}$ & $\begin{array}{l}\text { INDUCED } \\
\text { JOBS PER } \\
\text { YEAR }\end{array}$ & $\begin{array}{l}\text { TOTAL VALUE } \\
\text { ADDED (GDP) PER } \\
\text { YEAR (S, MILLIONS) }\end{array}$ & $\begin{array}{l}\text { TOTAL TAXES ON } \\
\text { PRODUCTION AND } \\
\text { IMPORTS (TOPI) PER } \\
\text { YEAR (S, MILLIONS) }\end{array}$ & $\begin{array}{l}\text { TOTAL EMPLOYEE } \\
\text { COMPENSATION } \\
\text { (EMPLOYEE INCOME) } \\
\text { PER YEAR (S, MILLIONS) }\end{array}$ \\
\hline North Carolina & 272 & 150 & 76 & 46 & $\$ 16.9$ & $\$ 0.9$ & $\$ 12.8$ \\
\hline North Dakota & 5 & 3 & 1 & 1 & $\$ 0.3$ & $\$ 0.0$ & $\$ 0.2$ \\
\hline Nebraska & 62 & 37 & 16 & 9 & $\$ 3.5$ & $\$ 0.2$ & $\$ 2.5$ \\
\hline New Hampshire & 0 & 0 & 0 & 0 & $\$ 0.0$ & $\$ 0.0$ & $\$ 0.0$ \\
\hline New Jersey ${ }^{a}$ & 0 & 0 & 0 & 0 & $\$ 0.0$ & $\$ 0.0$ & $\$ 0.0$ \\
\hline New Mexico & 9,832 & 5,929 & 2,497 & 1,407 & $\$ 502.9$ & $\$ 28.1$ & $\$ 358.0$ \\
\hline Nevada & 130 & 94 & 20 & 15 & $\$ 6.4$ & $\$ 0.5$ & $\$ 5.4$ \\
\hline New York & 4 & 2 & 1 & 1 & $\$ 0.2$ & $\$ 0.0$ & $\$ 0.2$ \\
\hline Ohio & 0 & 0 & 0 & 0 & $\$ 0.0$ & $\$ 0.0$ & $\$ 0.0$ \\
\hline Oklahoma & 64 & 40 & 14 & 9 & $\$ 3.2$ & $\$ 0.2$ & $\$ 2.2$ \\
\hline Oregon & 3,786 & 1,961 & 1,064 & 761 & $\$ 268.9$ & $\$ 14.2$ & $\$ 215.4$ \\
\hline Pennsylvania & 0 & 0 & 0 & 0 & $\$ 0.0$ & $\$ 0.0$ & $\$ 0.0$ \\
\hline Rhode Island ${ }^{\mathrm{a}}$ & 0 & 0 & 0 & 0 & $\$ 0.0$ & $\$ 0.0$ & $\$ 0.0$ \\
\hline South Carolina & 133 & 76 & 35 & 22 & $\$ 7.9$ & $\$ 0.5$ & $\$ 6.2$ \\
\hline South Dakota & 89 & 56 & 18 & 15 & $\$ 5.0$ & $\$ 0.3$ & $\$ 3.5$ \\
\hline Tennessee & 4 & 3 & 1 & 1 & $\$ 0.2$ & $\$ 0.0$ & $\$ 0.2$ \\
\hline Texas & 40 & 23 & 11 & 7 & $\$ 2.3$ & $\$ 0.1$ & $\$ 1.8$ \\
\hline Utah & 810 & 529 & 173 & 108 & $\$ 35.2$ & $\$ 2.1$ & $\$ 29.1$ \\
\hline Virginia & 8 & 5 & 2 & 1 & $\$ 0.4$ & $\$ 0.0$ & $\$ 0.3$ \\
\hline Vermont & 0 & 0 & 0 & 0 & $\$ 0.0$ & $\$ 0.0$ & $\$ 0.0$ \\
\hline Washington & 1,459 & 801 & 381 & 277 & $\$ 119.5$ & $\$ 8.6$ & $\$ 96.4$ \\
\hline Wisconsin & 2 & 1 & 0 & 0 & $\$ 0.1$ & $\$ 0.0$ & $\$ 0.1$ \\
\hline West Virginia & 7 & 4 & 1 & 1 & $\$ 0.3$ & $\$ 0.0$ & $\$ 0.2$ \\
\hline Wyoming & 5,774 & 3,302 & 1,502 & 971 & $\$ 320.2$ & $\$ 13.3$ & $\$ 228.6$ \\
\hline
\end{tabular}

Notes: Alaska, the District of Columbia, and Hawaii were not included in this analysis due to a lack of available forestry data; GDP = gross domestic product; a. Delaware, New Jersey, and Rhode Island do not have any rural counties as defined by the U.S. Department of Agriculture.

Source: BW Research. 
Table I2 provides the sum of economic outputs from investments in national wildfire risk management and its downstream impacts. The total values include the direct, indirect, and induced impacts on jobs, employee compen- sation, value added, and taxes on production and imports. These impacts are interpreted as impacts per year for $\mathbf{2 0}$ years.

Table I2 | Wildfire Risk Management in Rural and Urban Counties: State-Level Economic Investment Impacts

\begin{tabular}{|c|c|c|c|c|c|c|c|}
\hline $\begin{array}{l}\text { AVERAGE IMPACTS PER } \\
\text { YEAR FOR 20 YEARS } \\
\text { NATIONAL }\end{array}$ & $\begin{array}{l}\text { TOTAL } \\
\text { JOBS PER } \\
\text { YEAR }\end{array}$ & $\begin{array}{l}\text { DIRECT } \\
\text { JOBS PER } \\
\text { YEAR }\end{array}$ & $\begin{array}{l}\text { INDIRECT } \\
\text { JOBS PER } \\
\text { YEAR }\end{array}$ & $\begin{array}{l}\text { INDUCED } \\
\text { JOBS PER } \\
\text { YEAR }\end{array}$ & $\begin{array}{l}\text { TOTAL VALUE } \\
\text { ADDED (GDP) PER } \\
\text { YEAR (\$, MILLIONS) }\end{array}$ & $\begin{array}{l}\text { TOTAL TAXES ON } \\
\text { PRODUCTION AND } \\
\text { IMPORTS (TOPI) PER } \\
\text { YEAR (S, MILLIONS) }\end{array}$ & $\begin{array}{l}\text { TOTAL EMPLOYEE } \\
\text { COMPENSATION } \\
\text { (EMPLOYEE INCOME) } \\
\text { PER YEAR (\$, MILLIONS) }\end{array}$ \\
\hline Alabama & 77 & 42 & 22 & 13 & $\$ 4.8$ & $\$ 0.2$ & $\$ 3.3$ \\
\hline Arkansas & 2 & 1 & 1 & 0 & $\$ 0.1$ & $\$ 0.0$ & $\$ 0.1$ \\
\hline Arizona & 898 & 470 & 251 & 177 & $\$ 55.0$ & $\$ 3.5$ & $\$ 43.6$ \\
\hline California & 23,995 & 12,446 & 6,793 & 4,755 & $\$ 1,983.2$ & $\$ 120.1$ & $\$ 1,569.3$ \\
\hline Colorado & 3,883 & 2,102 & 1,178 & 603 & $\$ 211.5$ & $\$ 11.2$ & $\$ 167,0$ \\
\hline Connecticut & 5 & 3 & 1 & 1 & $\$ 0.3$ & $\$ 0.0$ & $\$ 0.2$ \\
\hline Delaware & 11 & 7 & 2 & 2 & $\$ 0.6$ & $\$ 0.0$ & $\$ 0.5$ \\
\hline Florida & 651 & 337 & 185 & 129 & $\$ 38.8$ & $\$ 2.5$ & $\$ 30.8$ \\
\hline Georgia & 574 & 311 & 151 & 112 & $\$ 37.0$ & $\$ 2.0$ & $\$ 28.1$ \\
\hline lowa & 1 & 1 & 0 & 0 & $\$ 0.1$ & $\$ 0.0$ & $\$ 0.0$ \\
\hline Idaho & 4,566 & 2,465 & 1,228 & 873 & $\$ 300.7$ & $\$ 16.0$ & $\$ 217.7$ \\
\hline Illinois & 0 & 0 & 0 & 0 & $\$ 0.0$ & $\$ 0.0$ & $\$ 0.0$ \\
\hline Indiana & 0 & 0 & 0 & 0 & $\$ 0.0$ & $\$ 0.0$ & $\$ 0.0$ \\
\hline Kansas & 60 & 35 & 15 & 10 & $\$ 3.7$ & $\$ 0.2$ & $\$ 2.2$ \\
\hline Kentucky & 189 & 114 & 43 & 33 & $\$ 10.5$ & $\$ 0.6$ & $\$ 7.9$ \\
\hline Louisiana & 130 & 79 & 31 & 20 & $\$ 6.5$ & $\$ 0.4$ & $\$ 5.1$ \\
\hline Maine & 0 & 0 & 0 & 0 & $\$ 0.0$ & $\$ 0.0$ & $\$ 0.0$ \\
\hline Maryland & 48 & 32 & 10 & 6 & $\$ 2.5$ & $\$ 0.2$ & $\$ 1.9$ \\
\hline Massachusetts & 0 & 0 & 0 & 0 & $\$ 0.0$ & $\$ 0.0$ & $\$ 0.0$ \\
\hline Michigan & 27 & 15 & 7 & 5 & $\$ 1.6$ & $\$ 0.1$ & $\$ 1.2$ \\
\hline Minnesota & 1,050 & 561 & 288 & 201 & $\$ 61.8$ & $\$ 3.7$ & $\$ 47.0$ \\
\hline Missouri & 2 & 1 & 0 & 0 & $\$ 0.1$ & $\$ 0.0$ & $\$ 0.1$ \\
\hline Mississippi & 216 & 121 & 60 & 34 & $\$ 12.1$ & $\$ 0.7$ & $\$ 8.5$ \\
\hline Montana & 3,836 & 2,198 & 996 & 642 & $\$ 210.8$ & $\$ 8.7$ & $\$ 149.9$ \\
\hline North Carolina & 474 & 264 & 132 & 78 & $\$ 28.4$ & $\$ 1.5$ & $\$ 21.2$ \\
\hline North Dakota & 6 & 3 & 1 & 1 & $\$ 0.4$ & $\$ 0.0$ & $\$ 0.3$ \\
\hline Nebraska & 62 & 37 & 16 & 9 & $\$ 3.5$ & $\$ 0.2$ & $\$ 2.5$ \\
\hline
\end{tabular}


Table I2 | Wildfire Risk Management in Rural and Urban Counties: State-Level Economic Investment Impacts (Cont.)

\begin{tabular}{|c|c|c|c|c|c|c|c|}
\hline $\begin{array}{l}\text { AVERAGE IMPACTS PER } \\
\text { YEAR FOR 20 YEARS } \\
\text { NATIONAL }\end{array}$ & $\begin{array}{l}\text { TOTAL } \\
\text { JOBS PER } \\
\text { YEAR }\end{array}$ & $\begin{array}{l}\text { DIRECT } \\
\text { JOBS PER } \\
\text { YEAR }\end{array}$ & $\begin{array}{l}\text { INDIRECT } \\
\text { JOBS PER } \\
\text { YEAR }\end{array}$ & $\begin{array}{l}\text { INDUCED } \\
\text { JOBS PER } \\
\text { YEAR }\end{array}$ & $\begin{array}{l}\text { TOTAL VALUE } \\
\text { ADDED (GDP) PER } \\
\text { YEAR (\$, MILLIONS) }\end{array}$ & $\begin{array}{l}\text { TOTAL TAXES ON } \\
\text { PRODUCTION AND } \\
\text { IMPORTS (TOPI) PER } \\
\text { YEAR (S, MILLIONS) }\end{array}$ & $\begin{array}{l}\text { TOTAL EMPLOYEE } \\
\text { COMPENSATION } \\
\text { (EMPLOYEE INCOME) } \\
\text { PER YEAR (S, MILLIONS) }\end{array}$ \\
\hline New Hampshire & 0 & 0 & 0 & 0 & $\$ 0.0$ & $\$ 0.0$ & $\$ 0.0$ \\
\hline New Jersey & 534 & 343 & 101 & 89 & $\$ 33.9$ & $\$ 2.5$ & $\$ 27.2$ \\
\hline New Mexico & 11,173 & 6,753 & 2,830 & 1,591 & $\$ 565.7$ & $\$ 31.5$ & $\$ 401.2$ \\
\hline Nevada & 147 & 107 & 23 & 17 & $\$ 7.2$ & $\$ 0.6$ & $\$ 6.0$ \\
\hline New York & 406 & 253 & 94 & 59 & $\$ 24.2$ & $\$ 1.5$ & $\$ 18.0$ \\
\hline Ohio & 0 & 0 & 0 & 0 & $\$ 0.0$ & $\$ 0.0$ & $\$ 0.0$ \\
\hline Oklahoma & 76 & 48 & 17 & 10 & $\$ 3.8$ & $\$ 0.2$ & $\$ 2.6$ \\
\hline Oregon & 5,626 & 2,935 & 1,572 & 1,119 & $\$ 388.9$ & $\$ 20.2$ & $\$ 307.4$ \\
\hline Pennsylvania & 0 & 0 & 0 & 0 & $\$ 0.0$ & $\$ 0.0$ & $\$ 0.0$ \\
\hline Rhode Island & 0 & 0 & 0 & 0 & $\$ 0.0$ & $\$ 0.0$ & $\$ 0.0$ \\
\hline South Carolina & 279 & 160 & 73 & 46 & $\$ 15.8$ & $\$ 1.0$ & $\$ 12.1$ \\
\hline South Dakota & 336 & 212 & 68 & 56 & $\$ 17.7$ & $\$ 1.1$ & $\$ 11.9$ \\
\hline Tennessee & 7 & 4 & 2 & 1 & $\$ 0.4$ & $\$ 0.0$ & $\$ 0.3$ \\
\hline Texas & 82 & 46 & 22 & 14 & $\$ 4.5$ & $\$ 0.2$ & $\$ 3.5$ \\
\hline Utah & 1,258 & 827 & 267 & 165 & $\$ 52.9$ & $\$ 3.1$ & $\$ 43.2$ \\
\hline Virginia & 11 & 7 & 2 & 1 & $\$ 0.6$ & $\$ 0.0$ & $\$ 0.4$ \\
\hline Vermont & 0 & 0 & 0 & 0 & $\$ 0.0$ & $\$ 0.0$ & $\$ 0.0$ \\
\hline Washington & 3,155 & 1,752 & 816 & 588 & $\$ 246.9$ & $\$ 17.3$ & $\$ 194.5$ \\
\hline Wisconsin & 2 & 1 & 0 & 0 & $\$ 0.1$ & $\$ 0.0$ & $\$ 0.1$ \\
\hline West Virginia & 12 & 8 & 3 & 2 & $\$ 0.5$ & $\$ 0.0$ & $\$ 0.4$ \\
\hline Wyoming & 5,792 & 3,312 & 1,507 & 974 & $\$ 321.1$ & $\$ 13.3$ & $\$ 229.2$ \\
\hline
\end{tabular}

Notes: Alaska, the District of Columbia, and Hawaii were not included in this analysis due to a lack of available forestry data; GDP = gross domestic product.

Source: BW Research. 


\section{APPENDIXJ: ECONOMIC MODELING METHODOLOGY, ENERGY SECTOR}

\section{$\mathbf{J}$ Introduction}

This appendix describes the overall approach, input parameters, data sources, and assumptions for modeling the economic impacts of federal investments in the four energy sector pathways presented in this paper: energy efficiency (EE); renewable energy (RE); transmission, distribution, and storage (TDS); and environmental remediation of abandoned fossil fuel sites.

We modeled investment impacts using the Economic Impact Analysis for Planning (IMPLAN) platform, an input-output model containing data on 546 sectors representing all private industries in the United States as defined by North American Industry Classification System (NAICS) codes. BW Research Partnership conducted the modeling based on specific policy and investment input assumptions developed by WRI in partnership with BW.

\section{J1.1 General Modeling Approach}

For each of the sectors below, the overall aim was to model the impact of an ambitious federal policy platform that could have a positive impact on rural communities in particular. The research team relied on data on existing federal policies and their impacts, expert consultation, and proposed legislation to define assumptions and inform the modeling process.

Most of the assumptions presented below are policy specific. For example, they are based on data from existing federal tax credits or grant and loan programs such as the federal production tax credit (PTC) in the power sector or existing block grant programs to fund building efficiency improvements, such as the State Energy Program (SEP) and Weatherization Assistance Program (WAP). We did this to ground input assumptions in a set of existing, well-documented policy mechanisms; however, all assumptions (and by extension results) are intended to be illustrative rather than prescriptive. In general, we also assumed that these policies and programs would be implemented at accelerated or heightened levels relative to historical funding to evaluate the potential for larger impact.

\section{J1.2 Rural Impact Assumptions}

For the energy sector, the modeling team assumed a federal investment allocation to rural areas of at least 15 percent of total national investments. Put another way, we assumed that at least 15 percent of each state's investment allocation for a given policy or pathway would go to rural counties. If a state's default allocation to rural counties was already 15 percent or more of its total investment, then the default allocation was retained. This reallocation process did not impact Delaware, the District of Columbia, New Jersey, and Rhode Island, since these regions do not have any rural counties as defined by the U.S. Department of Agriculture (USDA). Table J1 shows total federal investment and rural allocation using both the default modeling assumptions as well as the 15 percent minimum assumptions.

This "rural impact" assumption is intended to illustrate the potential for greater impact in rural areas should complementary measures be adopted to ensure that a minimum share of funding reaches them. It is also more aligned with the primary research goal of this paper: evaluating the potential impact that targeted federal investments in the new climate economy could have on rural regions. We used a value of 15 percent as a modeling construct for the minimum share; however, in reality a wide array of policy mechanisms may be adopted to achieve this threshold, including at the state and local levels. These could include targeting specific regions, using geographic equity as a performance metric, or improving coordination with rural implementing partners; however, this modeling exercise is agnostic in terms of the exact complementary measures employed.

Table J1 | Total Investment over 5 Years and Rural Allocation in Base Case and Rural Impact Case

FEDERAL INVESTMENT (\$, BILLIONS)
RURAL ALLOCATION (BASE CASE, S, BILLIONS)
RURAL ALLOCATION (15 PERCENT MINIMUM CASE, S, BILLIONS)

\begin{tabular}{|llll}
\hline Transmission, distribution, and storage & $\$ 98.0$ & $\$ 9.9$ & $\$ 17.1$ \\
\hline Energy efficiency & $\$ 41.3$ & $\$ 7.7$ & $\$ 10.4$ \\
\hline Renewable energy & $\$ 94.1$ & $\$ 11.8$ & $\$ 19.0$ \\
\hline Total clean energy investment & $\$ 233.4$ & $\$ 29.4$ & $\$ 46.5$
\end{tabular}

Source: WRI authors and BW Research. 
Cross-Cutting Methodological Details

The EE and TDS models operate under the same general framework, briefly described in this section. By contrast, the RE model is more tailored to renewable energy activities and was based on data and assumptions from the National Renewable Energy Laboratory's (NREL's) Jobs and Economic Development Impacts (JEDI) model. Modeling the impacts of investments in fossil fuel site remediation also followed a tailored approach based on expert consultation, public datasets on site locations, and project-level data. Full details on assumptions, inputs, and methods for each sector can be found in Section J2.

Below are methodological details that the EE and TDS models share.

\section{J1.2.1 Economic Input}

The energy efficiency and transmission, distribution, and storage models include three inputs: program description; federal investment amount; and private financing rate. The private financing rate multiplied by the federal investment is the total economic investment input to construct energy efficiency projects.

To account for interstate economic activity, we ran investment program impacts at the state and national levels using state- and national-level multipliers. We calculated the final, reported direct and indirect impacts using national-level multipliers, which we broke out by state by using each state's share of total aggregated impacts when run using the state-level multipliers. The induced impacts are the total aggregated induced impacts for all states. We chose this method of calculating total impacts to capture indirect impacts that are not accounted for when limiting impacts to state boundaries, while avoiding overestimating induced impacts.

\section{J1.2.2 Multipliers}

In this analysis, we used the Per Million Effects multipliers from IMPLAN, an economic modeling tool using 2018 data, available by industry and state and also for the nation as a whole. IMPLAN uses the Bureau of Economic Analysis (BEA) Regional Economic Accounts, Bureau of Labor Statistics (BLS) Census of Employment and Wages, Census Bureau County Business Patterns, and BEA National Income and Product Accounts data for its economic model. ${ }^{7}$

\section{J1.2.3 Direct, Indirect, and Induced Impacts}

Economic impact analyses report direct, indirect, and induced impacts. We used the region-industry allocation, described in the EE and TDS sections below, as the input value to derive indirect and induced output, and direct, indirect, and induced jobs, employee compensation, value added, and taxes on production and imports for a specific industry within a specific state through the Per Million Effects multipliers. These impacts are interpreted as capital expenses, meaning they happen only once.
We took an additional step to translate direct, indirect, and induced taxes on production and imports to local, state, and federal impacts. We ran the total industry allocation of funds at the national level through IMPLAN online, which produces tax impacts at the local, state, and federal levels split by direct, indirect, and induced impact type. We then took the share of each regional tax within the impact type, and multiplied by the national direct, indirect, and induced tax output generated using the methods described above. This was then further disaggregated by state using the state share of direct, indirect, and induced tax impacts.

\section{J1.2.4 Final Outputs and County Disaggregation}

The impact analysis produced the following outputs for each state and the United States as a whole, per year over the course of five years:

- Direct, indirect, induced, and total jobs

- Direct, indirect, induced, and total employee compensation

- Direct, indirect, induced, and total value added

- Local, state, federal, and total taxes on production and imports

Value added can be interpreted as gross domestic product (GDP).

We disaggregated state-level outputs into county-level outputs by taking each county's share of its respective state EE or TDS employment from U.S. Energy and Employment Report (USEER) data and multiplying by the state outputs. 


\section{J2 Energy Sector-Specific Methodologies}

\section{J2.1 Energy Efficiency Methodology}

\section{J2.1.1 Input Methodology}

Table J2 describes the total cost and leverage inputs of the policies chosen for the economic impact model of the energy efficiency investments.

The input cost assumptions for tax code sections 179D, 25C, and 45L; the State Energy Program (SEP); the Weatherization Assistance Program (WAP); and Energy Efficiency Conservation Block Grants were all derived from an analysis by the American Council for an Energy-Efficient Economy (Ungar et al. 2020). The tax code section 48C and industrial efficiency block grant input cost assumptions were derived from the Industrial Innovation Initiative (I3) (WRI and GPI 2020). Cost and leverage assumptions for the Rural Energy for America Program (REAP) came from a combination of sources: an analysis by the Center for American Progress (Bhattacharyya et al. 2020), the proposed 2019 Climate Stewardship Act (Booker 2019), the proposed $2021 \mathrm{Ag}$ riculture Resilience Act (Pingree 2021), and USDA program details. The cost assumptions for the USDA Energy Efficiency and Conservation Loan Program and the Rural Energy Savings Program (RESP) are working assumptions

Table J2 | Energy Efficiency Investment Program Inputs

\begin{tabular}{|c|c|c|c|c|c|c|}
\hline TITLE & $\begin{array}{l}\text { INVESTMENT } \\
\text { TYPE }\end{array}$ & $\begin{array}{l}\text { PRIVATE } \\
\text { LEVERAGE }\end{array}$ & $\begin{array}{l}\text { FEDERAL } \\
\text { INVESTMENT } \\
\text { (\$, BILLIONS) }\end{array}$ & $\begin{array}{l}\text { TOTAL INVESTMENT } \\
\text { INPUT (\$, BILLIONS) }\end{array}$ & $\begin{array}{l}\text { RURAL FEDERAL } \\
\text { INVESTMENT } \\
\text { (S, BILLIONS) }\end{array}$ & $\begin{array}{l}\text { TOTAL RURAL } \\
\text { INVESTMENT } \\
\text { INPUT } \\
\text { (\$, BILLIONS) }\end{array}$ \\
\hline $\begin{array}{l}\text { Extend and enhance commercial } \\
\text { building tax deduction (tax code } \\
\text { sec. 179D) }\end{array}$ & $\begin{array}{l}\text { Forgone tax } \\
\text { revenue }\end{array}$ & $0 \%$ & $\$ 3.28$ & $\$ 3.28$ & $\$ 0.30$ & $\$ 0.30$ \\
\hline $\begin{array}{l}\text { Renew advanced manufacturing } \\
\text { tax credit (sec. 48C) }\end{array}$ & $\begin{array}{l}\text { Forgone tax } \\
\text { revenue }\end{array}$ & $0 \%$ & $\$ 2.70$ & $\$ 2.70$ & $\$ 0.25$ & $\$ 0.25$ \\
\hline $\begin{array}{l}\text { Renew and refresh existing } \\
\text { homes tax credit (sec. } 25 \mathrm{C} \text { ) }\end{array}$ & $\begin{array}{l}\text { Forgone tax } \\
\text { revenue }\end{array}$ & $0 \%$ & $\$ 14.40$ & $\$ 14.40$ & $\$ 1.31$ & $\$ 1.31$ \\
\hline $\begin{array}{l}\text { Renew and refresh new homes } \\
\text { tax credit (sec. 45L) }\end{array}$ & $\begin{array}{l}\text { Forgone tax } \\
\text { revenue }\end{array}$ & $0 \%$ & $\$ 2.50$ & $\$ 2.50$ & $\$ 0.23$ & $\$ 0.23$ \\
\hline State Energy Program & Grant funding & $0 \%$ & $\$ 2.70$ & $\$ 2.70$ & $\$ 0.25$ & $\$ 0.25$ \\
\hline $\begin{array}{l}\text { Energy Efficiency Conservation } \\
\text { Block Grants }\end{array}$ & Grant funding & $0 \%$ & $\$ 2.40$ & $\$ 2.40$ & $\$ 0.22$ & $\$ 0.22$ \\
\hline Industrial efficiency block grants & Grant funding & $0 \%$ & $\$ 3.00$ & $\$ 3.00$ & $\$ 0.27$ & $\$ 0.27$ \\
\hline $\begin{array}{l}\text { Weatherization Assistance } \\
\text { Program }\end{array}$ & Grant funding & $0 \%$ & $\$ 5.00$ & $\$ 5.00$ & $\$ 0.45$ & $\$ 0.45$ \\
\hline $\begin{array}{l}\text { Rural Energy for America } \\
\text { Program (REAP) grant }\end{array}$ & Grant funding & $75 \%$ & $\$ 1.83$ & $\$ 3.20$ & $\$ 1.83$ & $\$ 3.20$ \\
\hline REAP loan & Loan program & $25 \%$ & $\$ 1.50$ & $\$ 1.87$ & $\$ 1.50$ & $\$ 1.87$ \\
\hline $\begin{array}{l}\text { USDA Energy Efficiency and } \\
\text { Conservation Loan Program }\end{array}$ & Loan program & $0 \%$ & $\$ 1.00$ & $\$ 1.00$ & $\$ 0.09$ & $\$ 0.09$ \\
\hline Rural Energy Savings Program & Loan program & $0 \%$ & $\$ 1.00$ & $\$ 1.00$ & $\$ 1.00$ & $\$ 1.00$ \\
\hline TOTAL & & & $\$ 41.31$ & $\$ 43.05$ & $\$ 7.68$ & $\$ 9.43$ \\
\hline
\end{tabular}

Note: UDSA = U.S. Department of Agriculture.

Source: BW Research. 
from WRI policy experts, based on current allocations. The REAP and RESP investments flow directly to rural communities, while all other investment vehicles are split between rural and urban areas.

The estimated investment from these programs totals $\$ 41.31$ billion in federal funds. We also assume an additional $\$ 1.75$ billion in leverage from USDA REAP, bringing the total to $\$ 43.05$ billion in nationwide investment. Of that, $\$ 9.43$ billion is assumed to be allocated to rural areas. The allocation process is detailed below.

\section{J2.1.2 Economic Impact Model Methodology}

The economic impacts measured in this model are from the construction, engineering, and financing of rural energy efficiency programs funded by this investment.

\section{Energy Efficiency Program Investment Spending Assumptions}

1. Regional allocation assumption

We allocated federal investment spending to rural areas based on whether the program targets rural areas and whether the program has historical geographic funding patterns to specific regions. If a program targets rural areas, we allocated the entire program investment to rural counties in the state. If the program does not target rural areas, we split the program investment between urban and rural areas and allocated to the rural areas of the state based on the share of energy efficiency employment in rural counties in the state. If a program has historical geographic funding patterns to specific states, as the SEP and WAP do, then we allocated the total program investment to states based on those patterns (see Tables $\mathrm{J} 6$ and J7). If a program does not have any historical geographic funding patterns or funding pattern data were not available, then we allocated the total program investment to states based on the state share of national EE employment in rural areas.

We assumed that at least 15 percent of each state's investment allocation will go to rural areas. If a state's default allocation is already 15 percent or more of its total investment to rural counties, then we retained the default allocation. This reallocation process does not impact Delaware, the District of Columbia, New Jersey, and Rhode Island since these regions do not have any rural counties as defined by the USDA.

\section{Industry allocation assumptions}

We allocated spending by industry based on two factors: the industries targeted by each policy, and the employment within the six-digit industry code (NAICS) for each state, translated to an IMPLAN industry code. To do this, we extrapolated NAICS-specific industry employment in the following way:

- Start with USEER 2020 employment data by value chain-Construction, and Professional and Business Services (PBS)-for each state.
- Collect employment by state for all Construction and PBS NAICS we sampled to build the USEER 2020 employment data (see Tables J3 and J4). ${ }^{8}$

- Assume distribution of non-energy engineering employment (NAICS 5413) in the PBS NAICS industry group is the same as in the energy sector.

- For energy-specific engineering NAICS employment, use proportion of engineering NAICS within PBS NAICS industry group to split USEER 2020 PBS employment data into the different NAICS codes.

- Assume distribution of non-energy construction employment across sampled NAICS is the same in the energy sector.

- For energy-specific construction employment, use proportion of construction NAICS within Construction NAICS Group to split USEER 2020 Construction employment into the different NAICS codes.

- Sum energy-specific construction and engineering NAICS employment, divide employment for each NAICS code by sum to get industry percent allocation of spending within each state by NAICS code.

We then used the "2017 NAICS to IMPLAN 546 Industries" crosswalk provided by IMPLAN to translate the NAICS code into IMPLAN code. ${ }^{9}$ Since IMPLAN does not provide a crosswalk for construction industries, we assumed employment in each identified construction IMPLAN code to be split evenly among the aligned NAICS codes; more information regarding this process can be found in Table J3. We then derived industry allocation of funds by program in the following way:

- Identify industries that are targeted by each program. A list of each program and their identified industry activities can be found in Table J5.Error! No bookmark name given.

- Split industry allocation within each program by each state's share of industry employment within the set of program-identified industries.

\section{Combined region and industry allocation}

To calculate the allocation of spending by both region and industry, we multiplied the state allocation of total program funding, outlined in Section A, by the industry allocation of funds within each state for each program, outlined in Section B. We then summed the allocated funds for matching industries across programs for the final state-industry allocation of funds. We used this final allocation as the input for the EE program economic impact analysis. 


\begin{tabular}{|c|c|c|}
\hline NAICS CODE & NAICS DESCRIPTION & IMPLAN CODE \\
\hline 236115 & New single-family housing construction (except for-sale builders) & 57 \\
\hline 236116 & New multifamily housing construction (except for-sale builders) & 58 \\
\hline 236117 & New housing for-sale builders & 59 \\
\hline 236118 & Residential remodelers & 61 \\
\hline 236210 & Industrial building construction & 51 \\
\hline 236220 & Commercial and institutional building construction & $50,52,53,55,56$ \\
\hline 237110 & Water and sewer line and related structures construction & 52 \\
\hline 238110 & Poured concrete foundation and structure contractors & $50,51,52,53,55,56,57,58,59,60,61$ \\
\hline 238120 & Structural steel and precast concrete contractors & $50,51,52,53,55,56,57,58,59,60,61$ \\
\hline 238140 & Masonry contractors & $50,51,52,53,55,56,57,58,59,60,61$ \\
\hline 238150 & Glass and glazing contractors & $50,51,52,53,55,56,57,58,59,60,61$ \\
\hline 238160 & Roofing contractors & $50,51,52,53,55,56,57,58,59,60,61$ \\
\hline 238170 & Siding contractors & $50,51,52,53,55,56,57,58,59,60,61$ \\
\hline 238210 & Electrical contractors and other wiring installation contractors & $50,51,52,53,55,56,57,58,59,60,61$ \\
\hline 238220 & Plumbing, heating, and air-conditioning contractors & $50,51,52,53,55,56,57,58,59,60,61$ \\
\hline 238310 & Drywall and insulation contractors & $50,51,52,53,55,56,57,58,59,60,61$ \\
\hline 238320 & Painting and wall covering contractors & $50,51,52,53,55,56,57,58,59,60,61$ \\
\hline 238330 & Flooring contractors & $50,51,52,53,55,56,57,58,59,60,61$ \\
\hline 238350 & Finish carpentry contractors & $50,51,52,53,55,56,57,58,59,60,61$ \\
\hline 238390 & Other building finishing contractors & $50,51,52,53,55,56,57,58,59,60,61$ \\
\hline 238910 & Site preparation contractors & $50,51,52,53,55,56,57,58,59,60,61$ \\
\hline 238990 & All other specialty trade contractors & $50,51,52,53,55,56,57,58,59,60,61$ \\
\hline
\end{tabular}

Note: NAICS = North American Industry Classification System; IMPLAN = Economic Impact Analysis for Planning

Source: BW Research; IMPLAN.

Table J4 | Professional and Business Services (PBS) Industry Group, NAICS to IMPLAN

\begin{tabular}{llll}
\hline NAICS CODE & NAICS DESCRIPTION & IMPLAN CODE & IMPLAN DESCRIPTION \\
\hline $\mathbf{5 4 1 3 1 0}$ & Architectural services & 457 & Architectural, engineering, and related services \\
$\mathbf{5 4 1 3 3 0}$ & Engineering services & 457 & Architectural, engineering, and related services \\
$\mathbf{5 4 1 3 4 0}$ & Drafting services & 457 & Architectural, engineering, and related services \\
$\mathbf{5 4 1 3 5 0}$ & Building inspection services & 457 & Architectural, engineering, and related services \\
$\mathbf{5 4 1 3 8 0}$ & Testing laboratories & 457 & Architectural, engineering, and related services
\end{tabular}

Note: NAICS = North American Industry Classification System; IMPLAN = Economic Impact Analysis for Planning.

Source: IMPLAN. 
Table J5 | Identified Industries by Energy Efficiency Investment Program

\section{INVESTMENT PROGRAM}

Extend and enhance commercial building tax deduction (tax code section 179D)

Renew advanced manufacturing tax credit (sec. 48C)

Renew and refresh existing homes tax credit (sec. 25C)

Renew and refresh new homes tax credit (sec. 45L)

State Energy Program

Energy Efficiency Conservation Block Grants

Industrial efficiency block grants

Weatherization Assistance Program

Rural Energy for America Program (REAP) grant

REAPloan

USDA Energy Efficiency Conservation Loan Program

Rural Energy Savings Program

\section{IDENTIFIED IMPLAN INDUSTRIES}

$50,51,52,53,55,56,60$

51,60

$57,58,59,61$

$57,58,59,61$

$50,51,52,53,55,56,57,58,59,60,61$

$50,51,52,53,55,56,57,58,59,60,61$

51,60

61

60

60

60

$50,51,52,53,55,56,57,58,59,60,61$

Note: IMPLAN = Economic Impact Analysis for Planning; USDA = U.S. Department of Agriculture.

Source: BW Research,

Table J6 | Department of Energy State Energy Program, Fiscal Year 2020 Allocation

\begin{tabular}{|c|c|c|c|c|c|}
\hline STATE & DOLLAR ALLOCATION & PERCENT ALLOCATION & STATE & DOLLAR ALLOCATION & PERCENT ALLOCATION \\
\hline Alaska & $\$ 447,530$ & $0.8 \%$ & Mississippi & $\$ 678,650$ & $1.2 \%$ \\
\hline Alabama & $\$ 914,490$ & $1.6 \%$ & Montana & $\$ 439,200$ & $0.8 \%$ \\
\hline Arkansas & $\$ 692,700$ & $1.2 \%$ & North Carolina & $\$ 1,314,330$ & $2.3 \%$ \\
\hline American Samoa & $\$ 298,870$ & $0.5 \%$ & North Dakota & $\$ 440,680$ & $0.8 \%$ \\
\hline Arizona & $\$ 885,880$ & $1.6 \%$ & Nebraska & $\$ 577,510$ & $1.0 \%$ \\
\hline California & $\$ 3,809,360$ & $6.8 \%$ & New Hampshire & $\$ 473,170$ & $0.8 \%$ \\
\hline Colorado & $\$ 895,290$ & $1.6 \%$ & New Jersey & $\$ 1,471,080$ & $2.6 \%$ \\
\hline Connecticut & $\$ 769,830$ & $1.4 \%$ & New Mexico & $\$ 538,150$ & $1.0 \%$ \\
\hline District of Columbia & $\$ 376,440$ & $0.7 \%$ & Nevada & $\$ 538,460$ & $1.0 \%$ \\
\hline Delaware & $\$ 402,630$ & $0.7 \%$ & New York & $\$ 2,825,340$ & $5.0 \%$ \\
\hline Florida & $\$ 2,058,830$ & $3.7 \%$ & Ohio & $\$ 2,006,330$ & $3.6 \%$ \\
\hline Georgia & $\$ 1,320,210$ & $2.4 \%$ & Oklahoma & $\$ 825,480$ & $1.5 \%$ \\
\hline Guam & $\$ 309,520$ & $0.6 \%$ & Oregon & $\$ 737,810$ & $1.3 \%$ \\
\hline Hawaii & $\$ 425,070$ & $0.8 \%$ & Pennsylvania & $\$ 2,078,180$ & $3.7 \%$ \\
\hline
\end{tabular}


Table J6 | Department of Energy State Energy Program, Fiscal Year 2020 Allocation (Cont.)

\begin{tabular}{|c|c|c|c|c|c|}
\hline STATE & DOLLAR ALLOCATION & PERCENT ALLOCATION & STATE & DOLLAR ALLOCATION & PERCENT ALLOCATION \\
\hline lowa & $\$ 814,800$ & $1.5 \%$ & Puerto Rico & $\$ 664,240$ & $1.2 \%$ \\
\hline Idaho & $\$ 479,780$ & $0.9 \%$ & Rhode Island & $\$ 433,770$ & $0.8 \%$ \\
\hline Illinois & $\$ 2,148,950$ & $3.8 \%$ & South Carolina & $\$ 841,860$ & $1.5 \%$ \\
\hline Indiana & $\$ 1,302,570$ & $2.3 \%$ & South Dakota & $\$ 415,820$ & $0.7 \%$ \\
\hline Kansas & $\$ 712,270$ & $1.3 \%$ & Tennessee & $\$ 1,087,870$ & $1.9 \%$ \\
\hline Kentucky & $\$ 905,080$ & $1.6 \%$ & Texas & $\$ 3,703,180$ & $6.6 \%$ \\
\hline Louisiana & $\$ 1,238,430$ & $2.2 \%$ & Utah & $\$ 599,080$ & $1.1 \%$ \\
\hline Massachusetts & $\$ 1,158,640$ & $2.1 \%$ & Virginia & $\$ 1,250,720$ & $2.2 \%$ \\
\hline Maryland & $\$ 991,160$ & $1.8 \%$ & U.S. Virgin Islands & $\$ 330,170$ & $0.6 \%$ \\
\hline Maine & $\$ 496,260$ & $0.9 \%$ & Vermont & $\$ 387,830$ & $0.7 \%$ \\
\hline Michigan & $\$ 1,762,710$ & $3.1 \%$ & Washington & $\$ 1,054,960$ & $1.9 \%$ \\
\hline Minnesota & $\$ 1,127,430$ & $2.0 \%$ & Wisconsin & $\$ 1,157,140$ & $2.1 \%$ \\
\hline Missouri & $\$ 1,072,710$ & $1.9 \%$ & West Virginia & $\$ 606,000$ & $1.1 \%$ \\
\hline \multirow[t]{2}{*}{ Northern Marianas } & $\$ 297,710$ & $0.5 \%$ & Wyoming & $\$ 407,840$ & $0.7 \%$ \\
\hline & & & U.S. TOTAL & $\$ 56,000,000$ & \\
\hline
\end{tabular}

Source: D0E 2020.

Table J7 | Department of Energy Weatherization Assistance Program, Fiscal Year 2019 Allocation

\begin{tabular}{|l|c|c|l|c|c|}
\hline STATE & Dollar ALLOCATION & PERCENT ALLOCATION & STATE & DOLLAR ALLOCATION & PERCENT ALLOCATION \\
\hline Alabama & $\$ 2,849,629$ & $1.1 \%$ & New Hampshire & $\$ 1,780,183$ & $0.7 \%$ \\
\hline Alaska & $\$ 2,053,765$ & $0.8 \%$ & New Jersey & $\$ 6,088,137$ & $2.3 \%$ \\
\hline Arizona & $\$ 1,831,626$ & $0.7 \%$ & New Mexico & $\$ 2,232,675$ & $0.9 \%$ \\
\hline Arkansas & $\$ 2,318,929$ & $0.9 \%$ & New York & $\$ 23,321,618$ & $8.9 \%$ \\
\hline California & $\$ 7,540,160$ & $2.9 \%$ & North Carolina & $\$ 5,064,596$ & $1.9 \%$ \\
\hline Colorado & $\$ 6,314,441$ & $2.4 \%$ & North Dakota & $\$ 2,782,844$ & $1.1 \%$ \\
\hline Connecticut & $\$ 3,117,380$ & $1.2 \%$ & Ohio & $\$ 15,710,535$ & $6.0 \%$ \\
\hline Delaware & $\$ 717,370$ & $0.3 \%$ & Oklahoma & $\$ 2,996,202$ & $1.1 \%$ \\
\hline District of Columbia & $\$ 714,233$ & $0.3 \%$ & Oregon & $\$ 3,325,518$ & $1.3 \%$ \\
\hline Florida & $\$ 2,705,406$ & $1.0 \%$ & Pennsylvania & $\$ 16,889,762$ & $6.4 \%$ \\
\hline Georgia & $\$ 3,788,068$ & $1.4 \%$ & Rhode Island & $\$ 1,352,790$ & $0.5 \%$ \\
\hline
\end{tabular}


Table J7 | Department of Energy Weatherization Assistance Program, Fiscal Year 2019 Allocation (Cont.)

\begin{tabular}{|c|c|c|c|c|c|}
\hline STATE & DOLLAR ALLOCATION & PERCENT ALLOCATION & STATE & DOLLAR ALLOCATION & PERCENT ALLOCATION \\
\hline Hawaii & $\$ 257,473$ & $0.1 \%$ & South Carolina & $\$ 2,168,457$ & $0.8 \%$ \\
\hline Idaho & $\$ 2,297,304$ & $0.9 \%$ & South Dakota & $\$ 2,136,561$ & $0.8 \%$ \\
\hline Illinois & $\$ 15,465,764$ & $5.9 \%$ & Tennessee & $\$ 5,045,797$ & $1.9 \%$ \\
\hline Indiana & $\$ 7,755,598$ & $3.0 \%$ & Texas & $\$ 6,811,752$ & $2.6 \%$ \\
\hline lowa & $\$ 5,586,637$ & $2.1 \%$ & Utah & $\$ 2,426,710$ & $0.9 \%$ \\
\hline Kansas & $\$ 2,892,165$ & $1.1 \%$ & Vermont & $\$ 1,506,339$ & $0.6 \%$ \\
\hline Kentucky & $\$ 5,234,906$ & $2.0 \%$ & Virginia & $\$ 4,743,147$ & $1.8 \%$ \\
\hline Louisiana & $\$ 1,695,764$ & $0.6 \%$ & Washington & $\$ 5,329,638$ & $2.0 \%$ \\
\hline Maine & $\$ 3,538,802$ & $1.3 \%$ & West Virginia & $\$ 3,587,126$ & $1.4 \%$ \\
\hline Maryland & $\$ 3,196,150$ & $1.2 \%$ & Wisconsin & $\$ 10,056,393$ & $3.8 \%$ \\
\hline Massachusetts & $\$ 7,507,308$ & $2.9 \%$ & Wyoming & $\$ 1,205,819$ & $0.5 \%$ \\
\hline Michigan & $\$ 17,869,403$ & $6.8 \%$ & American Samoa & $\$ 204,166$ & $0.1 \%$ \\
\hline Minnesota & $\$ 11,190,371$ & $4.3 \%$ & Guam & $\$ 213,233$ & $0.1 \%$ \\
\hline Mississippi & $\$ 1,852,245$ & $0.7 \%$ & Puerto Rico & $\$ 905,767$ & $0.3 \%$ \\
\hline Missouri & $\$ 6,876,381$ & $2.6 \%$ & $\begin{array}{l}\text { Northern Mariana } \\
\text { Islands }\end{array}$ & $\$ 205,882$ & $0.1 \%$ \\
\hline Montana & $\$ 2,855,298$ & $1.1 \%$ & Virgin Islands & $\$ 219,950$ & $0.1 \%$ \\
\hline Nebraska & $\$ 2,853,612$ & $1.1 \%$ & $\begin{array}{l}\text { Northern } \\
\text { Arapahoe Grant }\end{array}$ & $\$ 112,607$ & $0.0 \%$ \\
\hline Nevada & $\$ 1,199,608$ & $0.5 \%$ & Total & $\$ 262,500,000$ & \\
\hline
\end{tabular}

Source: D0E 2018.

\section{J2.2 Transmission, Distribution, and Storage Methodology}

\section{J2.2.1 Input Methodology}

Table J8 shows the total cost and leverage inputs of the policies chosen for the economic impact model of the TDS investment.

Cost assumptions for the 30 percent storage investment tax credit (ITC) were derived from an analysis by the Solar Energy Industries Association (SEIA 2019). The input cost assumptions for the 30 percent Transmission ITC were derived from an Edison Electric Institute report (EEI 2020). The section $48 \mathrm{C}$ input cost assumptions were derived from I3 (WRI and GPI 2020). The U.S. Department of Energy (DOE) Smart Grid Investment Grant program derived

its input cost assumptions from previous WRI research (Saha 2020), while the Electric Infrastructure Loan \& Loan Guarantee Program was based on historical funding levels. The Transportation Infrastructure Finance and Innovation Act program cost assumptions were based on an analysis by the Center for American Progress (Costa et al. 2019), as well as input from GridWise Alliance. The Expanding Access to Sustainable Energy Act input cost assumptions were derived from section 1183 of the act (Klobuchar 2019). The REAP investment flows directly to rural communities while all other investments are split between rural and urban areas. 


\begin{tabular}{|c|c|c|c|c|c|c|}
\hline TITLE & $\begin{array}{l}\text { INVESTMENT } \\
\text { TYPE }\end{array}$ & $\begin{array}{l}\text { PRIVATE } \\
\text { LEVERAGE }\end{array}$ & $\begin{array}{l}\text { FEDERAL } \\
\text { INVESTMENT } \\
\text { (\$, BILLIONS) }\end{array}$ & $\begin{array}{l}\text { TOTAL INVESTMENT } \\
\text { INPUT (S, BILLIONS) }\end{array}$ & $\begin{array}{l}\text { RURAL FEDERAL } \\
\text { INVESTMENT } \\
\text { (\$, BILLIONS) }\end{array}$ & $\begin{array}{l}\text { TOTAL RURAL } \\
\text { INVESTMENT INPUT } \\
\text { (\$, BILLIONS) }\end{array}$ \\
\hline $30 \%$ storage ITC & $\begin{array}{l}\text { Forgone tax } \\
\text { revenue }\end{array}$ & $0 \%$ & $\$ 0.30$ & $\$ 0.30$ & $\$ 0.03$ & $\$ 0.03$ \\
\hline $30 \%$ transmission ITC & $\begin{array}{l}\text { Forgone tax } \\
\text { revenue }\end{array}$ & $0 \%$ & $\$ 39.75$ & $\$ 39.75$ & $\$ 4.03$ & $\$ 4.03$ \\
\hline $\begin{array}{l}\text { Renew advanced manufacturing } \\
\text { tax credit (tax code section } 48 \mathrm{C} \text { ) }\end{array}$ & $\begin{array}{l}\text { Forgone tax } \\
\text { revenue }\end{array}$ & $0 \%$ & $\$ 2.70$ & $\$ 2.70$ & $\$ 0.27$ & $\$ 0.27$ \\
\hline $\begin{array}{l}\text { DOE Smart Grid Investment } \\
\text { Grant program }\end{array}$ & Grant funding & $100 \%$ & $\$ 20.00$ & $\$ 40.00$ & $\$ 2.03$ & $\$ 4.05$ \\
\hline $\begin{array}{l}\text { Electric Infrastructure Loan \& } \\
\text { Loan Guarantee Program }\end{array}$ & Loan program & $0 \%$ & $\$ 10.00$ & $\$ 10.00$ & $\$ 1.01$ & $\$ 1.01$ \\
\hline $\begin{array}{l}\text { Transportation Infrastructure } \\
\text { Finance and Innovation Act loans } \\
\text { for transmission infrastructure }\end{array}$ & Loan program & $100 \%$ & $\$ 25.00$ & $\$ 50.00$ & $\$ 2.53$ & $\$ 5.06$ \\
\hline $\begin{array}{l}\text { Expanding Access to Sustainable } \\
\text { Energy Act }\end{array}$ & Grant funding & $0 \%$ & $\$ 0.25$ & $\$ 0.25$ & $\$ 0.03$ & $\$ 0.03$ \\
\hline Total & & & $\$ 98.00$ & $\$ 143.00$ & $\$ 9.93$ & $\$ 14.49$ \\
\hline
\end{tabular}

Note: ITC = investment tax credit; DOE = Department of Energy.

Source: WRI authors and BW Research.

These investment programs total $\$ 98$ billion in federal funds; with $\$ 45$ billion in leverage funding, there is a total of $\$ 143$ billion in nationwide investment. Of that, $\$ 14.49$ billion is allocated to rural areas, $\$ 9.9$ billion being federal funds. The allocation process is detailed below.

\section{J2.2.2 Economic Impact Model Methodology}

The economic impacts measured in this model capture impacts from the construction, manufacturing, engineering, and financing of rural transmission, distribution, and storage programs funded by this investment.

\section{Regional Allocation Assumption}

We allocated federal investment spending to rural areas based on whether the program targets rural areas and current TDS employment. If a program targets rural areas, we allocated the total program investment to the state. If the program does not target rural areas, we split the total program investment between urban and rural areas and allocated to the rural areas of a state based on the share of TDS employment in rural counties in the state. The programs in this analysis either do not have any historical geographic funding patterns or funding pattern data were not available, so we allocated the total program investment to states based on the state share of national TDS employment in rural areas.

\section{Industry Allocation Assumption}

The programs listed as inputs for this model determined the allocation of funds into different industry sets, the Industry Mix and the Manufacturing Mix, depending on which industries the programs target. Table J9 shows the different programs and their identified industry sets. A breakdown of allocated funds by industry or industry group within the Industry Mix and Manufacturing Mix, as well as industry group definitions, are found in Tables $\mathrm{J} 10$ and J11. We allocated spending by specific industry within the Manufacturing and Computer Engineering industry groupings based on the share of employment within each six-digit NAICS industry for each state, converted to IMPLAN code.

\section{Combined Region and Industry Allocation}

To calculate the allocation of spending by region and industry, we multiplied the state allocation of total program funding, outlined in Section J3.2.1, by the industry allocation of funds within each state for each program. We then summed the allocated funds for matching industries across programs for the final state-industry allocation of funds. We used this final allocation as the input for the TDS program economic impact analysis. 
Table J9 | Program Description and Industry Set

INVESTMENT PROGRAM

$30 \%$ ITC storage

30\% ITC transmission

Renew advanced manufacturing tax credit (tax code section 48C)

DOE Smart Grid Investment Grant program

Electric Infrastructure Loan \& Loan Guarantee Program

Transportation Infrastructure Finance and Innovation Act loans for transmission infrastructure

Expanding Access to Sustainable Energy Act

\section{INDUSTRY SET}

Industry mix

Industry mix

Manufacturing mix

Industry mix

Industry mix

Industry mix

Industry mix

Note: ITC = investment tax credit; DOE = Department of Energy.

Source: BW Research.

Table J10 | Industry Mix Allocation of Funds and Industry Grouping Specification

\begin{tabular}{|c|c|c|c|}
\hline SHARE & GROUPING & IMPLAN CODE & DESCRIPTION \\
\hline $10 \%$ & & 47 & Electric power transmission and distribution \\
\hline $30 \%$ & & 52 & Construction of new power and communication structures \\
\hline $5 \%$ & & 56 & Construction of other new nonresidential structures \\
\hline $5 \%$ & & 60 & Maintenance and repair construction of nonresidential structures \\
\hline \multirow{4}{*}{$30 \%$} & \multirow{4}{*}{ Manufacturing } & 302 & Broadcast and wireless communications equipment manufacturing \\
\hline & & 315 & Totalizing fluid meter and counting device manufacturing \\
\hline & & 316 & Electricity and signal testing instruments manufacturing \\
\hline & & 339 & All other miscellaneous electrical equipment and component manufacturing \\
\hline \multirow{5}{*}{$20 \%$} & \multirow{5}{*}{$\begin{array}{l}\text { Computer } \\
\text { engineering }\end{array}$} & 428 & Software publishers \\
\hline & & 436 & Data processing, hosting, and related services \\
\hline & & 459 & Custom computer programming services \\
\hline & & 460 & Computer systems design services \\
\hline & & 461 & 0ther computer-related services, including facilities management \\
\hline
\end{tabular}

Note: IMPLAN = Economic Impact Analysis for Planning.

Source: BW Research. 
Table J11 | Manufacturing Mix Allocation of Funds and Industry Grouping Specification

\begin{tabular}{|c|c|c|c|}
\hline SHARE & GROUPING & IMPLAN CODE & DESCRIPTION \\
\hline $10 \%$ & & 47 & Electric power transmission and distribution \\
\hline $10 \%$ & & 51 & Construction of new manufacturing structures \\
\hline $30 \%$ & & 52 & Construction of new power and communication structures \\
\hline \multirow{4}{*}{$30 \%$} & \multirow{4}{*}{ Manufacturing } & 302 & Broadcast and wireless communications equipment manufacturing \\
\hline & & 315 & Totalizing fluid meter and counting device manufacturing \\
\hline & & 316 & Electricity and signal testing instruments manufacturing \\
\hline & & 339 & All other miscellaneous electrical equipment and component manufacturing \\
\hline \multirow{5}{*}{$20 \%$} & \multirow{5}{*}{$\begin{array}{l}\text { Computer } \\
\text { engineering }\end{array}$} & 428 & Software publishers \\
\hline & & 436 & Data processing, hosting, and related services \\
\hline & & 459 & Custom computer programming services \\
\hline & & 460 & Computer systems design services \\
\hline & & 461 & Other computer-related services, including facilities management \\
\hline
\end{tabular}

Note: IMPLAN = Economic Impact Analysis for Planning.

Source: BW Research.

\section{J2.3 Renewable Energy Methodology}

\section{J2.3.1 Input Methodology}

The inputs for the renewable energy economic impact model include a fiveyear extension of the wind production tax credit, a five-year 30 percent offshore wind investment tax credit, and a five-year 30 percent solar and other renewables investment tax credit. To calculate the total costs of the wind PTC and solar and other renewable energy ITC programs in terms of forgone tax revenues, we relied on a report from the Joint Committee on Taxation (JCT 2020). We calculated wind ITC program costs using data and assumptions provided in NREL's land-based wind JEDI model (NREL n.d.).

We assumed and estimated cost for an offshore wind ITC of $\$ 7.7$ billion each year for five years, derived from the NREL JEDI model (and explained in more detail in Section J4.2.2). We assumed an estimated cost for a wind PTC extension of $\$ 3.9$ billion in 2021, $\$ 2.9$ billion in 2022, and $\$ 2.7$ billion in 2023, 2024, and 2025. The solar and other renewable energy ITC extension would cost an estimated $\$ 7.7$ billion in 2021 and 2022, $\$ 7.3$ billion in 2023, and $\$ 6$ billion in 2024 and 2025. In total, these investments amount to an estimated $\$ 71.1$ billion in forgone government tax revenue over five years. Of this, we assumed $\$ 6.6$ billion is allocated to rural areas, derived by multiplying the share of total outputs in rural communities by the total nationwide forgone tax revenue (described in more detail below).
We also modelled the impacts of renewing the advanced manufacturing tax credit (48C), as well as the Rural Energy for America Program. We modelled these policies using the same framework as described in the previous sections. The input costs follow what is detailed in the energy efficiency modeling input cost assumption table. The industry allocation of investment follows the industry groups detailed in the TDS model section; the $48 \mathrm{C}$ uses the Manufacturing Mix of industries, detailed in Table J10, and REAP uses the Industry Mix, detailed in Table J11, for allocating funds to industries. A summary of renewable energy policy and investment assumptions is shown in Table J12. 


\begin{tabular}{|c|c|c|c|c|}
\hline & $\begin{array}{l}\text { FEDERAL } \\
\text { INVESTMENT } \\
\text { (\$, BILLIONS) }\end{array}$ & $\begin{array}{l}\text { TOTAL INVESTMENT } \\
\text { (S, BILLIONS) }\end{array}$ & $\begin{array}{l}\text { RURAL FEDERAL } \\
\text { INVESTMENT } \\
\text { (S, BILLIONS) }\end{array}$ & $\begin{array}{l}\text { RURAL TOTAL } \\
\text { INVESTMENT } \\
\text { (S, BILLIONS) }\end{array}$ \\
\hline $30 \%$ offshore wind ITC & $\$ 38.50$ & $\$ 38.50$ & $\$ 3.58$ & $\$ 3.58$ \\
\hline Extend PTC for wind and other renewable energy projects & $\$ 14.90$ & $\$ 14.90$ & $\$ 1.38$ & $\$ 1.38$ \\
\hline Extend 30\% ITC for solar and other renewables & $\$ 34.70$ & $\$ 34.70$ & $\$ 3.22$ & $\$ 3.22$ \\
\hline Renew tax code section $48 \mathrm{C}$ & $\$ 2.70$ & $\$ 2.70$ & $\$ 0.26$ & $\$ 0.26$ \\
\hline Renewable Energy Assistance Program & $\$ 3.33$ & $\$ 5.07$ & $\$ 3.33$ & $\$ 5.07$ \\
\hline Total & $\$ 94.1$ & $\$ 95.9$ & $\$ 11.8$ & $\$ 13.5$ \\
\hline
\end{tabular}

Note: ITC = investment tax credit; PTC = production tax credit.

Source: WRI authors and BW Research.

\section{J2.3.2 Economic Impact Model Methodology}

The economic impacts measured in this model capture impacts from the engineering, construction, and operation of rural renewable energy projects funded by these investment programs. All total economic impacts are interpreted over the course of five years.

\section{Wind PTC and Solar and Other Renewable Energy ITC Programs}

Inputs to our model from the wind PTC and solar and other renewable energy ITC programs were derived from an NREL report (Mai et al. 2016). In that report, annual changes to renewable energy installed capacity are modeled under two scenarios, one with an extension to the wind PTC and solar and other renewable energy ITC programs and one without an extension. Annual installed capacity changes are distinguished by "solar," "wind," and "all renewable energy" and are modeled over five years.

To adjust for increases in installed capacity since 2016, we took annual changes to installed capacity as a percentage of 2015 installed capacity, found in Koebrich et al. (2020). Using this most recent installed capacity data from the same source, 2018 data served as the new base, and we applied the percentage change in installed capacity to update the modeled changes. We subtracted "solar and wind capacity" changes from the "all renewable" changes to derive "all other renewable energy" changes in installed capacity.

We used the share of 2019 annual total net generation data for "small-scale solar" and "utility solar" data from Table 1.1.A from EIA (2021) to split the solar modeled annual changes to installed capacity into residential and utility scale for input into our multipliers.

\section{Offshore Wind ITC}

Since an offshore wind ITC is not modeled in the NREL study (Mai et al. 2016), we used projected new installed capacity from DOE (2015). Since this report was published, there has been a significant offshore wind ramp up in the United States. In 2019 alone, offshore wind project capacity grew by 2.7 gigawatts (GW), and state procurement agreements have grown by $10 \mathrm{GW}$ (NREL 2020). To adjust for this increase in activity and near-future capacity, we assumed $3.4 \mathrm{GW}$ of offshore capacity-both the offshore and land-based wind capacity additions-from the Department of Energy (DOE 2015, Table 3-3) as the offshore capacity inputs. We assumed a 30 percent wind ITC would increase the new annual additions by 30 percent, using a timeframe of 2021-30. We then added a base of 11.4 GW/year outlined in Table 3-3 (DOE 2015) to the non-extension scenario outlined above in Section J4.2.1, and the 14.8 GW/year to the extension scenario, also outlined above. We input the difference, 3.4 GW, into NREL's JEDI Offshore Wind model at the national level with default data to derive the annual install project cost of $\$ 7.68$ billion.

\section{C and REAP}

The $48 \mathrm{C}$ and REAP investments were modeled using the same methodology as in the energy efficiency and TDS modeling, with the same cost assumptions listed in the energy efficiency cost table, Table J2, and with the same IMPLAN industry multipliers detailed in Section J2.1.2. The only adjustment to the modeling process was that funds from these programs were allocated to states based on renewable energy generation employment data from the USEER instead of EE or TDS employment data. 


\section{Multipliers}

We derived renewable energy impact multipliers from a 2017 report conducted by BW Research on behalf of Vote Solar and the Union of Concerned Scientists (VS and UCS 2017). This report studied the economic impact of increased installed capacity of solar and wind electric power generation in Michigan. We used multipliers from this study instead of IMPLAN industry multipliers because these multipliers were derived to capture the impact of renewable energy-specific projects.

Multipliers from this study generated output in terms of direct, indirect, and induced jobs per MW, as well as local, state, and federal tax impacts per $1,100 \mathrm{MW}$ of generating capacity specific to wind, distributed solar, utility solar, and other renewables (RE) for both construction and operations and maintenance project phases. Other RE multipliers were derived by taking a weighted average of the previously listed impacts. We used a weighted average of IMPLAN Effects per Million multipliers to convert direct jobs to direct output, then converted to value added and employee compensation. The IMPLAN industries included in that weighted average can be found in Table J13.

Multipliers for the $48 \mathrm{C}$ and REAP impacts are the same as in the energy efficiency modeling section detailed previously.

Impacts

We modelled impacts from the PTC and ITC under both scenarios, one in which there is an extension of the programs and one in which there is not. After calculating impacts by running our inputs through our multipliers, we aggregated the total impacts of five years under both scenarios and subtracted the difference for each technology and project phase. This ensured that we would capture only the additional economic impacts of these programs.

\section{Final Outputs and State and County Disaggregation}

The impact analysis produced the following outputs for each state and the United States as a whole, per year over the course of five years:

- Direct, indirect, induced, and total jobs

- Direct, indirect, induced, and total employee compensation

- Direct, indirect, induced, and total value added

- Local, state, and federal taxes on production and imports

Value added can be interpreted as GDP.
We ran PTC and ITC impacts at the national level and split them out by state using USEER state rural employment data for solar electric power generation, wind electric power generation, and other renewable electric power generation. For the rural impact case, if a state's rural share of solar, wind, or other renewable generation is below 15 percent, then we changed the allocation of benefits to 15 percent. This reallocation process does not impact states whose rural share of solar, wind, or other renewable generation employment is at or above 15 percent, and it does not impact Delaware, the District of Columbia, New Jersey, and Rhode Island since these regions do not have any USDA-defined rural counties.

We further disaggregated state-level outputs into county-level outputs by taking each county's share of its respective state renewable energy employment from the USEER data and multiplying by the state outputs.

\section{Table J13 | IIMPLAN Industries Used for Renewable Energy} Investment Impact Modeling

\section{IMPLAN CODE DESCRIPTION}

\begin{tabular}{|c|c|}
\hline 39 & Electric power generation, hydroelectric \\
\hline 41 & Electric power generation, nuclear \\
\hline 42 & Electric power generation, solar \\
\hline 43 & Electric power generation, wind \\
\hline 44 & Electric power generation, geothermal \\
\hline 45 & Electric power generation, biomass \\
\hline 46 & Electric power generation, all other \\
\hline 47 & Electric power transmission and distribution \\
\hline 52 & $\begin{array}{l}\text { Construction of new power and communication } \\
\text { structures }\end{array}$ \\
\hline 56 & Construction of other new nonresidential structures \\
\hline 59 & Construction of other new residential structures \\
\hline 60 & $\begin{array}{l}\text { Maintenance and repair construction of nonresidential } \\
\text { structures }\end{array}$ \\
\hline 61 & $\begin{array}{l}\text { Maintenance and repair construction of residential } \\
\text { structures }\end{array}$ \\
\hline 457 & Architectural, engineering, and related services \\
\hline \multicolumn{2}{|c|}{ Note: IMPLAN = Economic Impact Analysis for Planning. } \\
\hline \multicolumn{2}{|c|}{ Source: BW Research; IMPLAN. } \\
\hline
\end{tabular}




\section{J2.4 Orphaned Oil and Gas Wells Methodology}

\section{J2.4.1 Input Methodology}

We derived the modeling inputs for this analysis based on identified orphan oil and gas wells data from the Interstate Oil and Gas Compact Commission (IOGCC 2020). Since these wells data are aggregated by state, we disaggregated by rural and urban areas using state government agency data. We used a sample of orphan wells by county from nine states to calculate a national average of the share of orphan wells in rural areas versus urban areas. We used this share to split the IOGCC-identified number of orphan oil and gas wells into rural and urban wells for states not contained in the sample. The rural-urban split for states within the sample came directly from the state agency data collected in the sample.

To estimate the cost of plugging and remediating these orphan wells, we received a sample of plugging and remediation project costs and activities from Plants \& Goodwin. This sample contains data from 16 rural oil and 11 rural gas well plug and reclamation projects in the Northeast region of the United States. We took a simple average of total project costs for each oil and well sample, then an average of those averages to estimate the average cost of an oil or gas well plug and remediation project. We then multiplied this average cost by the estimated number of orphan oil and gas wells for each state to calculate the estimated necessary investment in each state.

The Plants \& Goodwin data also include the share of total project costs associated with plugging activities and remediation activities. This was used to split the total investment into dollars invested into plugging activities and remediation activities, which we then used as the industry input into the IMPLAN multipliers.

Tables J14 and J15 outline the I0GCC-identified wells and estimated necessary funds for plugging and remediation of orphaned oil and gas wells by state at both the national and rural levels.

\section{J2.4.2 Economic Impact Model Methodology}

\section{Input Assumptions}

\section{Direct Jobs Inputs}

The Plants \& Goodwin data include a breakdown of each project by labor hour by occupation and activity type (plugging or remediation). We calculated average labor hours per project split between plugging and remediation activities. This served as the direct jobs multiplier using 2,080 hours per full-time equivalent.

\section{Remaining Impacts}

To calculate the remaining impacts, we multiplied the state investment in plugging activities detailed above by IMPLAN multipliers for industry code 36, "support activities for oil and gas operations," for each state, and state investment in remediation activities by IMPLAN multipliers for industry code 479, "waste management and remediation services," for each state.
Table J14 | IOGCC-Identified Orphan Oil and Gas Wells

\section{STATE} TOTAL IOGCC-ESTIMATED WELLS

RURAL WELLS

\begin{tabular}{|c|c|c|}
\hline Alabama & 3 & 1 \\
\hline Alaska & 15 & 15 \\
\hline Arkansas & 430 & 294 \\
\hline California & 4,844 & 55 \\
\hline Colorado & 288 & 203 \\
\hline Illinois & 4,239 & 2,894 \\
\hline Indiana & 1,107 & 756 \\
\hline Kansas & 5,653 & 4,850 \\
\hline Kentucky & 13,266 & 10,759 \\
\hline Louisiana & 3,966 & 1,413 \\
\hline Michigan & 116 & 79 \\
\hline Mississippi & 18 & 12 \\
\hline Montana & 232 & 158 \\
\hline Nebraska & 98 & 67 \\
\hline Nevada & 6 & 4 \\
\hline New Mexico & 708 & 483 \\
\hline New York & 2,400 & 1,638 \\
\hline Ohio & 910 & 621 \\
\hline Oklahoma & 1,075 & 734 \\
\hline Pennsylvania & 8,638 & 7,509 \\
\hline Texas & 6,208 & 4,464 \\
\hline Utah & 47 & 32 \\
\hline Virginia & 10 & 7 \\
\hline West Virginia & 4,555 & 3,109 \\
\hline Wyoming & 2,906 & 1,984 \\
\hline Total & 61,738 & 42,142 \\
\hline
\end{tabular}

Note: Only states with documented orphaned oil and gas wells are included in this table; IOGCC = Interstate Oil and Gas Compact Commission.

Source: IOGCC. 
Table J15 | Cost Estimate Input Allocations, IOGCC-Identified Orphan Oil and Gas Wells

\begin{tabular}{|c|c|c|c|c|c|c|}
\hline STATE & STATE TOTAL COST & RURAL TOTAL COST & TOTAL PLUG COST & $\begin{array}{l}\text { TOTAL COST OF } \\
\text { REMEDIATION }\end{array}$ & RURAL PLUG COST & $\begin{array}{l}\text { RURAL COST OF } \\
\text { REMEDIATION }\end{array}$ \\
\hline Alabama & $\$ 175,755$ & $\$ 42,537$ & $\$ 147,041$ & $\$ 28,713$ & $\$ 35,588$ & $\$ 6,949$ \\
\hline Alaska & $\$ 878,775$ & $\$ 868,380$ & $\$ 735,207$ & $\$ 143,567$ & $\$ 726,511$ & $\$ 141,869$ \\
\hline Arkansas & $\$ 25,191,541$ & $\$ 17,195,600$ & $\$ 21,075,945$ & $\$ 4,115,597$ & $\$ 14,386,318$ & $\$ 2,809,282$ \\
\hline California & $\$ 283,785,643$ & $\$ 3,233,444$ & $\$ 237,422,968$ & $\$ 46,362,675$ & $\$ 2,705,190$ & $\$ 528,255$ \\
\hline Colorado & $\$ 16,872,474$ & $\$ 11,888,552$ & $\$ 14,115,982$ & $\$ 2,756,493$ & $\$ 9,946,293$ & $\$ 1,942,258$ \\
\hline Illinois & $\$ 248,341,730$ & $\$ 169,516,624$ & $\$ 207,769,604$ & $\$ 40,572,126$ & $\$ 141,822,327$ & $\$ 27,694,298$ \\
\hline Indiana & $\$ 64,853,573$ & $\$ 44,268,673$ & $\$ 54,258,304$ & $\$ 10,595,269$ & $\$ 37,036,404$ & $\$ 7,232,269$ \\
\hline Kansas & $\$ 331,180,892$ & $\$ 284,151,830$ & $\$ 277,075,153$ & $\$ 54,105,739$ & $\$ 237,729,330$ & $\$ 46,422,500$ \\
\hline Kentucky & $\$ 777,188,344$ & $\$ 630,339,923$ & $\$ 650,217,402$ & $\$ 126,970,942$ & $\$ 527,359,925$ & $\$ 102,979,998$ \\
\hline Louisiana & $\$ 232,348,031$ & $\$ 82,803,364$ & $\$ 194,388,830$ & $\$ 37,959,201$ & $\$ 69,275,599$ & $\$ 13,527,765$ \\
\hline Michigan & $\$ 6,795,858$ & $\$ 4,638,813$ & $\$ 5,685,604$ & $\$ 1,110,254$ & $\$ 3,880,960$ & $\$ 757,853$ \\
\hline Mississippi & $\$ 1,054,530$ & $\$ 719,816$ & $\$ 882,249$ & $\$ 172,281$ & $\$ 602,218$ & $\$ 117,598$ \\
\hline Montana & $\$ 13,591,715$ & $\$ 9,277,626$ & $\$ 11,371,207$ & $\$ 2,220,508$ & $\$ 7,761,920$ & $\$ 1,515,706$ \\
\hline Nebraska & $\$ 5,741,328$ & $\$ 3,918,997$ & $\$ 4,803,355$ & $\$ 937,973$ & $\$ 3,278,742$ & $\$ 640,255$ \\
\hline Nevada & $\$ 351,510$ & $\$ 239,939$ & $\$ 294,083$ & $\$ 57,427$ & $\$ 200,739$ & $\$ 39,199$ \\
\hline New Mexico & $\$ 41,478,166$ & $\$ 28,312,755$ & $\$ 34,701,788$ & $\$ 6,776,378$ & $\$ 23,687,239$ & $\$ 4,625,516$ \\
\hline New York & $\$ 140,603,952$ & $\$ 95,975,442$ & $\$ 117,633,180$ & $\$ 22,970,772$ & $\$ 80,295,726$ & $\$ 15,679,716$ \\
\hline Ohio & $\$ 53,312,332$ & $\$ 36,390,688$ & $\$ 44,602,581$ & $\$ 8,709,751$ & $\$ 30,445,463$ & $\$ 5,945,226$ \\
\hline Oklahoma & $\$ 62,978,853$ & $\$ 42,989,000$ & $\$ 52,689,862$ & $\$ 10,288,992$ & $\$ 35,965,794$ & $\$ 7,023,206$ \\
\hline Pennsylvania & $\$ 506,057,057$ & $\$ 439,931,488$ & $\$ 423,381,420$ & $\$ 82,675,637$ & $\$ 368,058,928$ & $\$ 71,872,560$ \\
\hline Texas & $\$ 363,695,556$ & $\$ 261,541,703$ & $\$ 304,277,825$ & $\$ 59,417,730$ & $\$ 218,813,069$ & $\$ 42,728,634$ \\
\hline Utah & $\$ 2,753,494$ & $\$ 1,879,519$ & $\$ 2,303,650$ & $\$ 449,844$ & $\$ 1,572,458$ & $\$ 307,061$ \\
\hline Virginia & $\$ 585,850$ & $\$ 399,898$ & $\$ 490,138$ & $\$ 95,712$ & $\$ 334,566$ & $\$ 65,332$ \\
\hline West Virginia & $\$ 266,854,584$ & $\$ 182,153,391$ & $\$ 223,257,973$ & $\$ 43,596,611$ & $\$ 152,394,597$ & $\$ 29,758,794$ \\
\hline Wyoming & $\$ 170,247,952$ & $\$ 116,210,264$ & $\$ 142,434,175$ & $\$ 27,813,776$ & $\$ 97,224,742$ & $\$ 18,985,522$ \\
\hline Total & $\$ 3,616,919,494$ & $\$ 2,468,888,266$ & $\$ 3,026,015,526$ & $\$ 590,903,968$ & $\$ 2,065,540,645$ & $\$ 403,347,621$ \\
\hline
\end{tabular}

Note: Only states with documented orphaned oil and gas wells are included in this table.

Source: IOGCC; Plants \& Goodwin. 


\section{Multipliers}

In this analysis, we used the Per Million Effects multipliers from IMPLAN. ${ }^{10}$

To account for interstate economic activity, we ran impacts at the state and national levels using state-and national-level multipliers. We calculated the final, reported direct and indirect impacts using national-level multipliers that are broken out by state using each state's share of total aggregated impacts when run using the state-level multipliers. The induced impacts are the total aggregated induced impacts for all states. We chose this method of calculating total impacts to capture indirect impacts that are not accounted for when limiting impacts to state boundaries, while avoiding overestimating induced impacts.

\section{Direct, Indirect, and Induced Impacts}

Economic impact analyses report direct, indirect, and induced impacts. We used the region-industry allocation as the input value, otherwise defined as direct output, to derive direct, indirect, and induced jobs, employee compensation, value added, and taxes on production and imports for a specific industry within a specific state through the Per Million Effects multipliers. These impacts are interpreted as capital expenses, meaning they happen only once.

We took an additional step to translate direct, indirect, and induced taxes on production and imports into local, state, and federal impacts for each pathway. We ran the total industry allocation of funds for each pathway at the national level through IMPLAN online, which produces tax impacts at the local, state, and federal levels split by direct, indirect, and induced impact type. We then took the share of each regional tax within the impact type, and multiplied by the national direct, indirect, and induced tax output generated using the methods described above. This was then further disaggregated by state using the state share of direct, indirect, and induced tax impacts.

\section{Final Outputs and County Disaggregation}

The impact analysis produced the following outputs for each state and the United States as a whole, per year over the course of five years:

- Direct, indirect, induced, and total jobs

- Direct, indirect, induced, and total employee compensation

- Direct, indirect, induced, and total value added

- Local, state, federal, and total taxes on production and imports

Value added can be interpreted as GDP.

We disaggregated state-level outputs for each pathway into county-level outputs by taking each county's share of 2020 USEER data in oil and gas electric power generation and fuels production and multiplying by the state outputs.

\section{J2,5 Abandoned Coal Mines Methodology}

\section{J2.5.1 Input Methodology}

We derived the modeling inputs for this analysis from identified unfunded cost data for priority 1 and 2 abandoned coal mines per the eAMLIS database from the Office of Surface Mining Reclamation and Enforcement (OSMRE). Priority 1 and 2, or "high priority," mines are defined as posing a threat to the health, safety, and general welfare of people. Unfunded costs were summed by county and state; costs associated with mines on tribal lands were included in the state in which the mine is located.

Table J16 outlines the eAMLIS-estimated necessary investments by state at both the national and rural levels.

\section{Table J16 | OSMRRE eAMLIS Database Estimated Unfunded Costs}

STATE

\section{Alaska}

Alabama

Arkansas

Arizona

California

Colorado

Georgia

lowa

Illinois

Indiana

Kansas

Kentucky

Louisiana

Maryland

Michigan

Missouri

Mississippi

Montana

North Dakota

TOTAL UNFUNDED COSTS

RURAL UNFUNDED COSTS

\section{$\$ 37,328,803$}

$\$ 275,778,129$

$\$ 14,255,613$

$\$ 945,300$

$\$ 120,000$

$\$ 64,548,068$

$\$ 175,000$

$\$ 77,067,940$

$\$ 118,527,653$

$\$ 167,575,216$

$\$ 794,275,064$

$\$ 681,698,457$

$\$ 13,539,838$

$\$ 36,627,019$

$\$ 3,615,000$

$\$ 108,250,142$

$\$ 43,625$

$\$ 218,615,813$

$\$ 37,441,361$
$\$ 30,100,318$

$\$ 29,734,402$

$\$ 9,710,092$

$\$ 561,300$

$\$ 0$

$\$ 33,188,728$

$\$ 0$

$\$ 74,539,685$

$\$ 68,467,763$

$\$ 91,493,657$

$\$ 735,748,276$

$\$ 622,159,463$

$\$ 111,563$

$\$ 9,571,525$

\section{$\$ 0$}

$\$ 51,348,072$

\section{$\$ 18,625$}

$\$ 75,252,400$

$\$ 29,870,927$


Table J16 | OSMRE eAMILIS Database Estimated Unfunded Costs (Cont.)

\begin{tabular}{l|l|l}
\hline STATE & TOTAL UNFUNDED COSTS & RURAL UNFUNDED COSTS \\
\hline
\end{tabular}

\begin{tabular}{|lcc|}
\hline New Mexico & $\$ 35,985,046$ & $\$ 25,637,860$ \\
\hline Ohio & $\$ 397,763,300$ & $\$ 248,351,221$ \\
\hline Oklahoma & $\$ 97,674,716$ & $\$ 43,290,292$ \\
\hline Pennsylvania & $\$ 3,924,023,166$ & $\$ 1,141,388,403$ \\
\hline Tennessee & $\$ 15,120,651$ & $\$ 8,133,539$ \\
\hline Texas & $\$ 7,295,971$ & $\$ 7,220,971$ \\
\hline Utah & $\$ 6,354,545$ & $\$ 5,312,840$ \\
\hline Virginia & $\$ 99,943,967$ & $\$ 90,368,566$ \\
\hline West Virginia & $\$ 1,273,373,214$ & $\$ 635,012,066$ \\
\hline Wyoming & $\$ 79,397,562$ & $\$ 78,891,062$ \\
\hline U.S. Total & $\$ 8,587,360,179$ & $\$ 4,145,483,616$ \\
\hline
\end{tabular}

Note: This table only includes states with priority 1 and 2 abandoned coal mines per the eAMLIS database from the Office of Surface Mining Reclamation and Enforcement; OSMRE = Office of Surface Mining Reclamation and Enforcement.

Source: OSMRE EAMLIS.

\section{J2.5.2 Economic Impact Model Methodology}

Input Assumptions

1. Direct Jobs Inputs

Direct jobs for reclaiming abandoned coal mines were drawn from a study by the Western Organization of Resource Councils (WORC 2020; see also Kuipers 2020). This report estimates employment derived from coal mine cleanup based on project costs across Colorado, Montana, Navajo Nation, Arizona, New Mexico, North Dakota, Utah, and Wyoming. In Table 7 of the appendix report (Kuipers 2020), WORC estimates that, using labor as 15 percent of bond costs, there are 2,087 blue collar jobs created from a total project cost of $\$ 834.7$ million. WORC also estimates that an additional 10 percent more jobs are created in white collar positions, which creates a total direct jobs per million multiplier of 2.75. We used this as input for direct jobs across all regions, multiplying by the state investment detailed above.

\section{Remaining Impacts}

To calculate the remaining impacts, we multiplied the state investment in abandoned coal mine reclamation detailed above by IMPLAN multipliers for industry code 21 , "coal mining," for each state.

\section{Multipliers}

In this analysis, we used the Per Million Effects multipliers from IMPLAN." Due to a lack of multiplier data for IMPLAN industry 21, we used multiplier data from Alabama for Georgia's impacts, from Missouri for lowa's impacts, and from Indiana for Michigan's impacts as proxy.

To account for interstate economic activity, we ran impacts at the state and national levels using state- and national-level multipliers. We calculated the final, reported direct and indirect impacts using national-level multipliers broken out by state using each state's share of total aggregated impacts when run using the state-level multipliers. The induced impacts are the total aggregated induced impacts for all states. We chose this method of calculating total impacts to capture indirect impacts that are not accounted for when limiting impacts to state boundaries, while avoiding overestimating induced impacts.

\section{Direct, Indirect, and Induced Impacts}

Economic impact analyses report direct, indirect, and induced impacts. We used the region-industry allocation as the input value, otherwise defined as direct output. This was used to derive direct, indirect, and induced jobs, employee compensation, value added, and taxes on production and imports for a specific industry within a specific state through the Per Million Effects multipliers. These impacts are interpreted as capital expenses, meaning they happen only once.

We took an additional step to translate direct, indirect, and induced taxes on production and imports into local, state, and federal impacts for each pathway. We ran the total industry allocation of funds for each pathway at the national level through IMPLAN online, which produces tax impacts at the local, state, and federal levels split by direct, indirect, and induced impact type. We then took the share of each regional tax within the impact type, and multiplied by the national direct, indirect, and induced tax output generated using the methods described above. This was then further disaggregated by state using the state share of direct, indirect, and induced tax impacts.

\section{Final Outputs and County Disaggregation}

The impact analysis produced the following outputs for each state and the United States as a whole, per year over the course of five years:

- Direct, indirect, induced, and total jobs

- Direct, indirect, induced, and total employee compensation

- Direct, indirect, induced, and total value added

- Local, state, federal, and total taxes on production and imports

Value added can be interpreted as GDP.

We disaggregated state-level outputs for each pathway into county-level outputs by taking each county's share of its respective state's unfunded cost data and multiplying by the state outputs. 


\section{APPENDIX K: ECONOMIC MODELING} METHODOLOGY, LAND SECTOR

\section{K1 Input Methodology}

We derived modeling inputs for this analysis from county-level data on potential implementation acreage for each land sector pathway; and average cost of implementation per acre. For more information on data sources for each pathway, see Table K1.

\section{K1.1 Acreage}

The acreage estimates for reforestation on both federal and non-federal lands were drawn from a study conducted by The Nature Conservancy (Cook-Patton et al. 2020), which maps reforestation opportunity in the United States. The acreage estimates for restocking degraded forests on both federal and non-federal lands came from USFS Forest Inventory and Analysis (FIA) data (USFS 2021), which provides acreage data for poorly stocked forests (10-30 percent density) and medium-stocked forests (30-60 percent density). We supplemented FIA data with an unpublished analysis from Ohio State University (Sohngen 2018), which quantifies restocking opportunities in forests with greater than 25 percent canopy cover to avoid any duplication between the reforestation and restocking assessments. Restocking opportunities are considered only in the eastern United States, where patterns of carbon uptake and storage in forests are expected to remain relatively unchanged under most climate warming scenarios through 2050, without the accelerated negative effects of wildfire, disease, and other disturbances anticipated to occur in western forests (Vose et al. 2012).

This analysis also included agroforestry opportunity on non-federal lands, including silvopasture, alley cropping, and windbreaks. We derived the acreage available for silvopasture from reforestation opportunities on pasture land (Cook-Patton et al. 2020), while we calculated alley cropping potential using crop acreage data from the USDA Farm Service Agency (USDA 2017) based on the methodology from Fargione et al. (2018). For windbreak potential, the analysis used the national acreage found by Fargione et al. (2018) and allocated it by county according to actual USDA Cropland Reserve Program enrollment data for windbreaks and shelterbelts.

We derived fire risk management opportunity acreage estimates from the Wildfire Hazard Potential (WHP) spatial dataset, which assigns four levels of fire risk ranging from "low" to "very high" (Dillon and Gilbertson-Day 2020). This analysis includes acres designated as "high" or "very high" fire risk in the WHP dataset and only includes land with greater than 25 percent canopy cover.

\section{K1.2 Cost}

To estimate the investment need associated with tree restoration on both federal and non-federal lands, including opportunities for reforestation; restocking; and agroforestry (on non-federal lands only), this analysis used regional per-acre cost estimates for replanting hardwoods and softwoods; hardwood and softwood natural regeneration; and planting hardwoods and softwoods on cropland and on pasture (Bair and Alig 2006). We applied these regional costs to county-level acreage data to estimate total investment need. Reforestation and restocking costs assumed active replanting on forest land, silvopasture assumed planting on pasture, and alley cropping and windbreaks assumed planting on cropland. Cost estimates assumed that plantings would favor hardwoods in the Northeast, Lake States, and Corn Belt and softwoods in other regions, consistent with Fargione et al. (2021). We adjusted all costs for inflation to reflect 2021 dollars.

Investment needs for fire risk management were derived from per-acre cost estimates in the Forest Service Activity Tracking System (FACTS) database, which documents planning costs for prescribed burning and fuel treatments in national forests across the country. Project costs from 2016 to 2020 were averaged by state and applied to "high" or "very high" risk acres identified in the WHP dataset.

Tables K2 and K3 outline the estimated necessary funds for each land sector activity by state at both the national and rural levels. 
Table K1 | Data Sources for Land Sector Pathways

PATHWAY

Tree restoration on Bair and Alig 2006

federal lands

Tree restoration on Bair and Alig 2006

non-federal lands

\section{COST PER ACRE DATA SOURCE}

management
U.S. Forest Service, Forest Service Activity

Tracking System $2021^{\circ}$

\section{ACREAGE DATA SOURCE}

Reforestation: Cook-Patton et al. 2020

Restocking: USFS 2021; Sohngen 2018

Reforestation: Cook-Patton et al. 2020

Restocking: FIA (USFS 2021); Sohngen 2018

Agroforestry, silvopasture: Cook-Patton et al. 2020

Agroforestry, alley cropping: USDA Farm Service Agency crop acreage data (USDA 2017)

Agroforestry, windbreaks: Fargione et al. 2018; Natural Resources Conservation Service Conservation Reserve Program enrollment data (FSA 2020)

Dillion and Gilbertson-Day 2020

Note: a. Data provided to WRI authors by Margaret Farrell, Hazardous Fuels Program Analyst, U.S. Forest Service, February 18, 2021.

Table K2 | Cost Estimate Input Allocations, National

\section{TREE RESTORATION ON NON-FEDERAL LANDS}

\begin{tabular}{|c|c|c|c|c|c|}
\hline STATE & $\begin{array}{l}\text { TREE RESTORATION } \\
\text { ON FEDERAL LANDS }\end{array}$ & $\begin{array}{l}\text { NON-FEDERAL } \\
\text { REFORESTATION/ RESTOCKING }\end{array}$ & AGROFORESTRY & $\begin{array}{l}\text { FIRE RISK } \\
\text { MANAGEMENT }\end{array}$ & TOTAL \\
\hline Alabama & $\$ 53,081,530$ & $\$ 1,537,434,818$ & $\$ 781,450,608$ & $\$ 36,400,634$ & $\$ 2,408,367,590$ \\
\hline Arizona & $\$ 354,346,588$ & $\$ 608,259,373$ & $\$ 55,998,421$ & $\$ 386,781,830$ & $\$ 1,405,386,212$ \\
\hline Arkansas & $\$ 195,944,517$ & $\$ 1,632,524,727$ & $\$ 969,322,961$ & $\$ 1,017,720$ & $\$ 2,798,809,925$ \\
\hline California & $\$ 547,641,821$ & $\$ 900,488,872$ & $\$ 268,632,739$ & $\$ 11,554,464,929$ & $\$ 13,271,228,361$ \\
\hline Colorado & $\$ 1,123,053,405$ & $\$ 895,700,193$ & $\$ 676,960,578$ & $\$ 1,470,830,741$ & $\$ 4,166,544,917$ \\
\hline Connecticut & $\$ 121,738$ & $\$ 164,059,926$ & $\$ 62,223,833$ & $\$ 2,097,907$ & $\$ 228,503,405$ \\
\hline Delaware & $\$ 2,246,943$ & $\$ 89,606,041$ & $\$ 66,570,810$ & $\$ 5,025,360$ & $\$ 163,449,154$ \\
\hline Florida & $\$ 131,149,059$ & $\$ 1,361,826,668$ & $\$ 564,779,871$ & $\$ 251,114,611$ & $\$ 2,308,870,209$ \\
\hline Georgia & $\$ 59,670,517$ & $\$ 1,468,526,334$ & $\$ 615,022,876$ & $\$ 220,104,069$ & $\$ 2,363,323,796$ \\
\hline Idaho & $\$ 735,574,662$ & $\$ 1,049,354,924$ & $\$ 373,473,935$ & $\$ 2,029,836,263$ & $\$ 4,188,239,784$ \\
\hline Illinois & $\$ 40,746,269$ & $\$ 1,557,373,799$ & $\$ 1,044,791,875$ & $\$ 0$ & $\$ 2,642,911,943$ \\
\hline Indiana & $\$ 45,017,225$ & $\$ 1,969,398,877$ & $\$ 778,072,585$ & $\$ 0$ & $\$ 2,792,488,687$ \\
\hline
\end{tabular}


Table K2 | Cost Estimate Input Allocations, National (Cont.)

\begin{tabular}{|c|c|c|c|c|c|}
\hline \multirow[b]{2}{*}{ STATE } & \multirow[b]{2}{*}{$\begin{array}{l}\text { TREE RESTORATION } \\
\text { ON FEDERAL LANDS }\end{array}$} & \multicolumn{2}{|c|}{ TREE RESTORATION ON NON-FEDERAL LANDS } & \multirow[b]{2}{*}{$\begin{array}{l}\text { FIRE RISK } \\
\text { MANAGEMENT }\end{array}$} & \multirow[b]{2}{*}{ TOTAL } \\
\hline & & $\begin{array}{l}\text { NON-FEDERAL } \\
\text { REFORESTATION/ RESTOCKING }\end{array}$ & AGROFORESTRY & & \\
\hline lowa & $\$ 290,173,833$ & $\$ 1,716,218,925$ & $\$ 958,832,939$ & $\$ 517,509$ & $\$ 2,965,743,207$ \\
\hline Kansas & $\$ 7,515,931$ & $\$ 888,318,371$ & $\$ 744,916,746$ & $\$ 30,046,071$ & $\$ 1,670,797,119$ \\
\hline Kentucky & $\$ 53,532,778$ & $\$ 1,140,295,888$ & $\$ 1,178,350,314$ & $\$ 83,889,263$ & $\$ 2,456,068,243$ \\
\hline Louisiana & $\$ 53,192,300$ & $\$ 1,139,751,349$ & $\$ 344,984,848$ & $\$ 49,266,757$ & $\$ 1,587,195,254$ \\
\hline Maine & $\$ 13,508,971$ & $\$ 1,175,674,648$ & $\$ 132,873,289$ & $\$ 0$ & $\$ 1,322,056,908$ \\
\hline Maryland & $\$ 10,704,595$ & $\$ 398,736,281$ & $\$ 353,019,319$ & $\$ 19,079,263$ & $\$ 781,539,458$ \\
\hline Massachusetts & $\$ 6,472,150$ & $\$ 273,210,787$ & $\$ 73,789,504$ & $\$ 13,935$ & $\$ 353,486,376$ \\
\hline Michigan & $\$ 195,994,491$ & $\$ 2,567,770,783$ & $\$ 1,035,988,250$ & $\$ 10,887,956$ & $\$ 3,810,641,480$ \\
\hline Minnesota & $\$ 219,299,059$ & $\$ 1,933,469,347$ & $\$ 1,051,643,756$ & $\$ 412,095,511$ & $\$ 3,616,507,673$ \\
\hline Mississippi & $\$ 121,302,839$ & $\$ 1,474,352,124$ & $\$ 651,263,162$ & $\$ 89,180,631$ & $\$ 2,336,098,756$ \\
\hline Missouri & $\$ 212,169,691$ & $\$ 3,557,837,328$ & $\$ 4,250,514,819$ & $\$ 589,766$ & $\$ 8,021,111,603$ \\
\hline Montana & $\$ 769,998,018$ & $\$ 1,239,175,127$ & $\$ 970,566,863$ & $\$ 1,566,480,892$ & $\$ 4,546,220,900$ \\
\hline Nebraska & $\$ 7,129,553$ & $\$ 1,028,256,450$ & $\$ 1,414,436,474$ & $\$ 26,672,778$ & $\$ 2,476,495,255$ \\
\hline Nevada & $\$ 515,220,093$ & $\$ 185,622,911$ & $\$ 125,312,014$ & $\$ 54,873,024$ & $\$ 881,028,041$ \\
\hline New Hampshire & $\$ 25,985,107$ & $\$ 320,179,098$ & $\$ 55,070,373$ & $\$ 0$ & $\$ 401,234,578$ \\
\hline New Jersey & $\$ 13,566,034$ & $\$ 327,052,753$ & $\$ 86,127,448$ & $\$ 234,253,298$ & $\$ 660,999,533$ \\
\hline New Mexico & $\$ 501,137,596$ & $\$ 1,004,262,884$ & $\$ 85,260,880$ & $\$ 4,911,882,878$ & $\$ 6,502,544,238$ \\
\hline New York & $\$ 19,244,771$ & $\$ 1,807,495,684$ & $\$ 1,587,859,731$ & $\$ 172,342,079$ & $\$ 3,586,942,265$ \\
\hline North Carolina & $\$ 57,131,403$ & $\$ 992,270,236$ & $\$ 654,875,914$ & $\$ 196,855,468$ & $\$ 1,901,133,022$ \\
\hline North Dakota & $\$ 17,686,065$ & $\$ 352,542,467$ & $\$ 1,562,891,519$ & $\$ 2,646,804$ & $\$ 1,935,766,854$ \\
\hline Ohio & $\$ 39,066,201$ & $\$ 2,216,138,739$ & $\$ 1,905,576,044$ & $\$ 5,060$ & $\$ 4,160,786,044$ \\
\hline Oklahoma & $\$ 1,554,547$ & $\$ 300,607,902$ & $\$ 644,912,316$ & $\$ 31,048,816$ & $\$ 978,123,580$ \\
\hline Oregon & $\$ 147,930,423$ & $\$ 304,535,396$ & $\$ 394,330,659$ & $\$ 2,412,507,155$ & $\$ 3,259,303,633$ \\
\hline Pennsylvania & $\$ 55,858,253$ & $\$ 2,061,808,151$ & $\$ 1,630,767,189$ & $\$ 82,791$ & $\$ 3,748,516,384$ \\
\hline Rhode Island & $\$ 116,570$ & $\$ 35,448,453$ & $\$ 9,296,428$ & $\$ 0$ & $\$ 44,861,451$ \\
\hline South Carolina & $\$ 40,134,237$ & $\$ 707,020,819$ & $\$ 311,251,397$ & $\$ 117,710,580$ & $\$ 1,176,117,034$ \\
\hline South Dakota & $\$ 128,307,335$ & $\$ 1,084,222,945$ & $\$ 1,535,054,319$ & $\$ 134,726,838$ & $\$ 2,882,311,438$ \\
\hline Tennessee & $\$ 66,976,337$ & $\$ 1,264,788,022$ & $\$ 1,013,514,490$ & $\$ 2,713,496$ & $\$ 2,347,992,345$ \\
\hline
\end{tabular}


Table K2 | Cost Estimate Input Allocations, National (Cont.)

\begin{tabular}{|c|c|c|c|c|c|}
\hline STATE & $\begin{array}{l}\text { TREE RESTORATION } \\
\text { ON FEDERAL LANDS }\end{array}$ & $\begin{array}{l}\text { NON-FEDERAL } \\
\text { REFORESTATION/ RESTOCKING }\end{array}$ & AGROFORESTRY & $\begin{array}{l}\text { FIRE RISK } \\
\text { MANAGEMENT }\end{array}$ & TOTAL \\
\hline Texas & $\$ 2,561,261$ & $\$ 422,272,541$ & $\$ 1,430,847,517$ & $\$ 29,324,610$ & $\$ 1,885,005,928$ \\
\hline Utah & $\$ 997,863,686$ & $\$ 453,424,690$ & $\$ 166,030,253$ & $\$ 434,143,744$ & $\$ 2,051,462,373$ \\
\hline Vermont & $\$ 18,052,538$ & $\$ 336,913,630$ & $\$ 220,764,575$ & $\$ 0$ & $\$ 575,730,742$ \\
\hline Virginia & $\$ 63,964,688$ & $\$ 730,474,675$ & $\$ 815,794,223$ & $\$ 4,200,094$ & $\$ 1,614,433,680$ \\
\hline Washington & $\$ 70,886,550$ & $\$ 287,770,861$ & $\$ 466,868,448$ & $\$ 1,450,121,684$ & $\$ 2,275,647,543$ \\
\hline West Virginia & $\$ 73,182,920$ & $\$ 1,121,853,749$ & $\$ 470,053,503$ & $\$ 4,440,718$ & $\$ 1,669,530,890$ \\
\hline Wisconsin & $\$ 102,563,914$ & $\$ 2,145,720,612$ & $\$ 1,238,401,641$ & $\$ 800,830$ & $\$ 3,487,486,997$ \\
\hline Wyoming & $\$ 681,667,303$ & $\$ 508,619,699$ & $\$ 330,134,171$ & $\$ 2,375,041,203$ & $\$ 3,895,462,376$ \\
\hline United States & $\$ 8,890,246,314$ & $\$ 50,738,668,878$ & $\$ 36,159,476,428$ & $\$ 30,816,115,564$ & $\$ 126,604,507,184$ \\
\hline
\end{tabular}

Note: Alaska, the District of Columbia, and Hawaii were not included in this analysis due to a lack of available forestry data.

Source: WRI Authors.

Table K3 | Cost Estimate Input Allocations, Rural

\section{TREE RESTORATION ON NON-FEDERAL LANDS}

\begin{tabular}{|c|c|c|c|c|c|}
\hline STATE & $\begin{array}{l}\text { FEDERAL REFORESTATION/ } \\
\text { RESTOCKING }\end{array}$ & $\begin{array}{l}\text { NON-FEDERAL } \\
\text { REFORESTATION/ RESTOCKING }\end{array}$ & AGROFORESTRY & $\begin{array}{l}\text { FIRE RISK } \\
\text { MANAGEMENT }\end{array}$ & TOTAL \\
\hline Alabama & $\$ 29,787,778$ & $\$ 880,344,853$ & $\$ 409,549,222$ & $\$ 16,297,540$ & $\$ 1,335,979,393$ \\
\hline Arizona & $\$ 117,002,840$ & $\$ 312,374,261$ & $\$ 12,580,270$ & $\$ 190,221,115$ & $\$ 632,178,486$ \\
\hline Arkansas & $\$ 163,510,297$ & $\$ 1,184,554,001$ & $\$ 669,874,172$ & $\$ 351,531$ & $\$ 2,018,290,001$ \\
\hline California & $\$ 392,183,523$ & $\$ 461,337,822$ & $\$ 100,980,583$ & $\$ 6,899,491,741$ & $\$ 7,853,993,670$ \\
\hline Colorado & $\$ 919,456,049$ & $\$ 702,285,693$ & $\$ 577,372,911$ & $\$ 1,073,200,207$ & $\$ 3,272,314,860$ \\
\hline Connecticut & $\$ 29,860$ & $\$ 30,805,029$ & $\$ 16,889,085$ & $\$ 0$ & $\$ 47,723,974$ \\
\hline Delaware & $\$ 0$ & $\$ 0$ & $\$ 0$ & $\$ 0$ & $\$ 0$ \\
\hline Florida & $\$ 22,722,060$ & $\$ 458,756,288$ & $\$ 216,771,667$ & $\$ 74,874,585$ & $\$ 773,124,601$ \\
\hline Georgia & $\$ 27,692,381$ & $\$ 837,205,818$ & $\$ 326,334,112$ & $\$ 124,376,034$ & $\$ 1,315,608,345$ \\
\hline Idaho & $\$ 581,304,510$ & $\$ 861,678,637$ & $\$ 275,755,418$ & $\$ 1,830,759,519$ & $\$ 3,549,498,083$ \\
\hline Illinois & $\$ 27,055,307$ & $\$ 1,069,797,506$ & $\$ 743,415,659$ & $\$ 0$ & $\$ 1,840,268,472$ \\
\hline Indiana & $\$ 31,977,958$ & $\$ 1,032,316,924$ & $\$ 423,897,385$ & $\$ 0$ & $\$ 1,488,192,267$ \\
\hline
\end{tabular}


Table K3 | Cost Estimate Input Allocations, Rural (Cont.)

\section{TREE RESTORATION ON NON-FEDERAL LANDS}

\begin{tabular}{|c|c|c|c|c|c|}
\hline STATE & $\begin{array}{l}\text { FEDERAL REFORESTATION/ } \\
\text { RESTOCKING }\end{array}$ & $\begin{array}{l}\text { NON-FEDERAL } \\
\text { REFORESTATION/ RESTOCKING }\end{array}$ & AGROFORESTRY & $\begin{array}{l}\text { FIRE RISK } \\
\text { MANAGEMENT }\end{array}$ & TOTAL \\
\hline lowa & $\$ 229,357,062$ & $\$ 1,246,887,171$ & $\$ 779,178,342$ & $\$ 21,312$ & $\$ 2,255,443,887$ \\
\hline Kansas & $\$ 6,626,891$ & $\$ 636,623,880$ & $\$ 519,719,720$ & $\$ 25,206,352$ & $\$ 1,188,176,842$ \\
\hline Kentucky & $\$ 45,584,247$ & $\$ 846,715,490$ & $\$ 766,770,937$ & $\$ 83,850,772$ & $\$ 1,742,921,447$ \\
\hline Louisiana & $\$ 31,180,070$ & $\$ 664,619,926$ & $\$ 168,191,611$ & $\$ 21,253,027$ & $\$ 885,244,634$ \\
\hline Maine & $\$ 7,681,754$ & $\$ 935,505,148$ & $\$ 86,178,936$ & $\$ 0$ & $\$ 1,029,365,838$ \\
\hline Maryland & $\$ 2,751,970$ & $\$ 51,553,267$ & $\$ 76,662,680$ & $\$ 9,553,156$ & $\$ 140,521,073$ \\
\hline Massachusetts & $\$ 8,614$ & $\$ 36,725,377$ & $\$ 9,656,913$ & $\$ 0$ & $\$ 46,390,903$ \\
\hline Michigan & $\$ 194,137,594$ & $\$ 1,843,573,547$ & $\$ 604,229,785$ & $\$ 10,887,956$ & $\$ 2,652,828,883$ \\
\hline Minnesota & $\$ 141,974,179$ & $\$ 1,238,091,990$ & $\$ 677,513,120$ & $\$ 307,574,537$ & $\$ 2,365,153,826$ \\
\hline Mississippi & $\$ 81,655,648$ & $\$ 1,136,885,398$ & $\$ 476,869,245$ & $\$ 56,521,733$ & $\$ 1,751,932,024$ \\
\hline Missouri & $\$ 196,650,143$ & $\$ 2,642,516,939$ & $\$ 2,984,435,188$ & $\$ 525,845$ & $\$ 5,824,128,114$ \\
\hline Montana & $\$ 718,899,111$ & $\$ 1,132,429,704$ & $\$ 900,279,542$ & $\$ 1,407,463,318$ & $\$ 4,159,071,675$ \\
\hline Nebraska & $\$ 5,730,467$ & $\$ 894,589,030$ & $\$ 1,237,728,281$ & $\$ 26,663,016$ & $\$ 2,164,710,794$ \\
\hline Nevada & $\$ 437,520,190$ & $\$ 159,574,019$ & $\$ 122,401,868$ & $\$ 48,710,934$ & $\$ 768,207,012$ \\
\hline New Hampshire & $\$ 25,952,375$ & $\$ 249,775,522$ & $\$ 34,218,076$ & $\$ 0$ & $\$ 309,945,974$ \\
\hline New Jersey & $\$ 0$ & $\$ 0$ & $\$ 0$ & $\$ 0$ & $\$ 0$ \\
\hline New Mexico & $\$ 420,642,260$ & $\$ 849,669,636$ & $\$ 67,729,034$ & $\$ 4,343,519,230$ & $\$ 5,681,560,160$ \\
\hline New York & $\$ 5,060,743$ & $\$ 965,429,573$ & $\$ 766,094,052$ & $\$ 1,625,755$ & $\$ 1,738,210,122$ \\
\hline North Carolina & $\$ 42,286,616$ & $\$ 496,162,639$ & $\$ 255,563,244$ & $\$ 114,930,701$ & $\$ 908,943,200$ \\
\hline North Dakota & $\$ 17,668,222$ & $\$ 271,859,411$ & $\$ 1,380,473,713$ & $\$ 2,572,567$ & $\$ 1,672,573,913$ \\
\hline Ohio & $\$ 19,196,946$ & $\$ 1,277,605,282$ & $\$ 1,135,221,070$ & $\$ 3,179$ & $\$ 2,432,026,477$ \\
\hline Oklahoma & $\$ 1,261,100$ & $\$ 228,415,014$ & $\$ 525,992,521$ & $\$ 26,227,609$ & $\$ 781,896,244$ \\
\hline Oregon & $\$ 117,906,873$ & $\$ 196,900,230$ & $\$ 235,587,342$ & $\$ 1,642,267,870$ & $\$ 2,192,662,314$ \\
\hline Pennsylvania & $\$ 49,885,608$ & $\$ 954,147,185$ & $\$ 704,031,014$ & $\$ 0$ & $\$ 1,708,063,806$ \\
\hline Rhode Island & $\$ 0$ & $\$ 0$ & $\$ 0$ & $\$ 0$ & $\$ 0$ \\
\hline South Carolina & $\$ 18,617,314$ & $\$ 280,582,511$ & $\$ 119,223,203$ & $\$ 57,436,412$ & $\$ 475,859,439$ \\
\hline South Dakota & $\$ 51,841,223$ & $\$ 971,965,102$ & $\$ 1,392,147,712$ & $\$ 36,993,940$ & $\$ 2,452,947,977$ \\
\hline Tennessee & $\$ 33,664,414$ & $\$ 703,082,955$ & $\$ 554,802,480$ & $\$ 1,700,286$ & $\$ 1,293,250,136$ \\
\hline
\end{tabular}


Table K3 | Cost Estimate Input Allocations, Rural (Cont.)

TREE RESTORATION ON NON-FEDERAL LANDS

\begin{tabular}{|c|c|c|c|c|c|}
\hline STATE & $\begin{array}{l}\text { FEDERAL REFORESTATION/ } \\
\text { RESTOCKING }\end{array}$ & $\begin{array}{l}\text { NON-FEDERAL } \\
\text { REFORESTATION/ RESTOCKING }\end{array}$ & AGROFORESTRY & $\begin{array}{l}\text { FIRE RISK } \\
\text { MANAGEMENT }\end{array}$ & TOTAL \\
\hline Texas & $\$ 983,080$ & $\$ 237,229,257$ & $\$ 988,873,751$ & $\$ 14,816,410$ & $\$ 1,241,902,498$ \\
\hline Utah & $\$ 888,484,970$ & $\$ 342,744,121$ & $\$ 100,172,593$ & $\$ 284,009,753$ & $\$ 1,615,411,436$ \\
\hline Vermont & $\$ 17,501,398$ & $\$ 283,478,099$ & $\$ 166,007,733$ & $\$ 0$ & $\$ 466,987,229$ \\
\hline Virginia & $\$ 30,982,385$ & $\$ 318,686,582$ & $\$ 358,662,845$ & $\$ 3,123,088$ & $\$ 711,454,900$ \\
\hline Washington & $\$ 28,351,629$ & $\$ 104,047,873$ & $\$ 215,397,508$ & $\$ 683,849,376$ & $\$ 1,031,646,386$ \\
\hline West Virginia & $\$ 63,698,245$ & $\$ 710,444,302$ & $\$ 292,015,221$ & $\$ 2,518,924$ & $\$ 1,068,676,692$ \\
\hline Wisconsin & $\$ 92,639,234$ & $\$ 1,556,841,114$ & $\$ 733,098,535$ & $\$ 792,172$ & $\$ 2,383,371,056$ \\
\hline Wyoming & $\$ 669,632,857$ & $\$ 489,552,289$ & $\$ 308,510,662$ & $\$ 2,368,001,659$ & $\$ 3,835,697,467$ \\
\hline United States & $\$ 7,008,737,996$ & $\$ 32,786,366,411$ & $\$ 23,517,058,960$ & $\$ 21,792,193,163$ & $\$ 85,104,356,529$ \\
\hline
\end{tabular}

Note: Alaska, the District of Columbia, and Hawaii were not included in this analysis due to a lack of available forestry data.

Source: WRI Authors.

\section{K2 Economic Impact Model Methodology}

\section{K2.1 Investment Spending Assumptions}

\section{K2.1.1 Region}

We derived the regional allocation of investment through the cost estimation outlined above. We then aggregated these costs per county by state, for both rural- and national-level impacts.

\section{K2.1.2 Industry}

We allocated spending by industry based on two factors: the industries targeted by each land sector activity, and the distribution of project funds to industry, translated to IMPLAN code. We derived the distribution of project funds to industry based on a 2010 University of Oregon report (Nielsen-Pincus and Moseley 2010). This report was recommended by multiple interviewees as a primary source for modeling restoration efforts. It details that project funds are allocated among project management, technical planning and design, and labor- and equipment-intensive industries. We used a variation on the overall, upland, and riparian distributions from Table 2 in the report, omitting the equipment-intensive (watershed) allocation and dividing the remaining industries by the sum of their allocations. The new allocations are outlined in Table K4.
The distribution to each broad industry category outlined above was then further allocated to IMPLAN industries, based on the land sector activity. To allocate to IMPLAN industries, we combined the project management, labor intensive, and technical planning and design shares listed above into one category: support activities for agriculture and forestry. We then split the remaining share of activities evenly among forestry, forest products, and timber tract production and commercial logging to account for labor-intensive and equipment-intensive forestry activities. The IMPLAN industry codes that correspond to those industries and their respective allocations are detailed in Table K5.

\section{K2.1.3 Region and Industry}

To calculate the allocation of spending by region and industry, we multiplied the state allocation of total program funding, outlined in Section K1.1, by the industry allocation of funds within each program. We then summed the allocated funds for matching industries across programs for the final state-industry allocation of funds. We used this final allocation as the input for the economic impact analysis. 


\section{K2.1.4 Multipliers}

In this analysis, we used the Per Million Effects multipliers from IMPLAN. Due to inconsistencies in the underlying data, we used the Montana region Per Million Effects multiplier for Wyoming to ensure more comparable outputs.

To account for interstate economic activity, we ran impacts at the state and national levels, using state- and national-level multipliers. We calculated the final, reported direct and indirect impacts using national-level multipliers that are broken out by state using each state's share of total aggregated impacts when run using the state-level multipliers. The induced impacts are the total aggregated induced impacts for all states. We chose this method of calculating total impacts to capture indirect impacts that are not accounted for when limiting impacts to state boundaries, while avoiding overestimating induced impacts.

\section{K2.1.5 Direct, Indirect, and Induced Impacts}

Economic impact analyses report direct, indirect, and induced impacts. We used the region-industry allocation as the input value, otherwise defined as direct output, to derive direct, indirect, and induced jobs, employee compensation, value added, and taxes on production and imports for a specific industry within a specific state through the Per Million Effects multipliers. These impacts are interpreted as capital expenses, meaning they happen only once.

We took an additional step to translate direct, indirect, and induced taxes on production and imports into local, state, and federal impacts for each pathway. We ran the total industry allocation of funds for each pathway at the national level through IMPLAN online, which produces tax impacts at the local, state, and federal levels split by direct, indirect, and induced impact type. We then took the share of each regional tax within the impact type, and multiplied by the national direct, indirect, and induced tax output generated using the methods described above. This was then further disaggregated by state using the state share of direct, indirect, and induced tax impacts.

\section{K2.1.6 Final Outputs and County Disaggregation}

The impact analysis produced the following outputs for each state and the United States as a whole, per year over the course of 20 years:

- Direct, indirect, induced, and total Jobs

- Direct, indirect, induced, and total employee compensation

- Direct, indirect, induced, and total value added

- Local, state, federal, and total taxes on production and imports

Value added can be interpreted as GDP.

We disaggregated state-level outputs for each pathway into county-level outputs by taking each county's share of its respective state investment from our cost data and multiplying by the state outputs.

\section{K2.1.7 Downstream Outputs}

We generated additional outputs quantifying economic impacts as a result of harvested wood from fire management projects. To measure this, we derived direct sawmill jobs from Collaborative Forest Landscape Restoration CFLRP data, then input them into IMPLAN per million multipliers for industry code 132, "sawmills." We derived the direct sawmill jobs by taking the direct mill processing component jobs from each CFLRP 2019 annual project report and dividing by project cost (including both federal funding and private and state match funding). Table L6 contains the total project cost, direct mill jobs, and jobs per million. We then used the median jobs per million from this sample and multiplied by the total funds invested in fire management by state. We then used this as the direct input for the IMPLAN industry code 132 multipliers to derive the remaining impacts, using the same methodology described above. 


\begin{tabular}{|c|c|c|c|c|c|c|}
\hline & $\begin{array}{l}\text { LABOR } \\
\text { INTENSIVE }\end{array}$ & $\begin{array}{l}\text { EQUIPMENT INTENSIVE } \\
\text { (WATERSHED OMITTED) }\end{array}$ & $\begin{array}{l}\text { EQUIPMENT INTENSIVE } \\
\text { (FORESTRY) }\end{array}$ & $\begin{array}{l}\text { TECHNICAL PLANNING } \\
\text { AND DESIGN }\end{array}$ & $\begin{array}{l}\text { PROJECT } \\
\text { MANAGEMENT }\end{array}$ & $\begin{array}{l}\text { TOTAL } \\
\text { COST }\end{array}$ \\
\hline Overall & 2 & 34 & 5 & 4 & 55 & 100 \\
\hline Overall & $3.0 \%$ & $0.0 \%$ & $7.6 \%$ & $6.1 \%$ & $83.3 \%$ & $100 \%$ \\
\hline Upland & 2 & 14 & 14 & 7 & 62 & 100 \\
\hline Upland & $2.4 \%$ & $0.0 \%$ & $16.5 \%$ & $8.2 \%$ & $72.9 \%$ & $100 \%$ \\
\hline Riparian & 3 & 8 & 0 & 8 & 80 & 100 \\
\hline Riparian & $3.3 \%$ & $0.0 \%$ & $0.0 \%$ & $8.8 \%$ & $87.9 \%$ & $100 \%$ \\
\hline Weighted riparian & $2.6 \%$ & $0.0 \%$ & $12.4 \%$ & $8.4 \%$ & $76.7 \%$ & $100 \%$ \\
\hline
\end{tabular}

Source: BW Research.

Table K5 | IMPLAN Industry Descriptions and Allocations

\begin{tabular}{c|l|c|c|c|}
\hline IMPLAN CODE & DESCRIPTION & $\begin{array}{l}\text { FIRE RISK } \\
\text { MANAGEMENT }\end{array}$ & $\begin{array}{l}\text { FEDERAL } \\
\text { REFORESTATION }\end{array}$ & $\begin{array}{l}\text { NON-FEDERAL } \\
\text { REFORESTATION }\end{array}$ \\
\hline 15 & Forestry, forest products, and timber tract production & $10 \%$ & $10 \%$ & $10 \%$ \\
\hline 16 & Commercial logging & $10 \%$ & $10 \%$ & $10 \%$ \\
19 & Support activities for agriculture and forestry & $79 \%$ & $79 \%$ & $79 \%$ \\
\hline
\end{tabular}

Note: IMPLAN = Economic Impact Analysis for Planning.

Source: BW Research. 
Table K6 | CFLRP 2019 Costs and Direct Mill Jobs

\section{PROGRAM NAME}

Accelerating Longleaf Pine Regeneration CFLR10-19

Amador Calaveras Consensus Group (ACCG) Cornerstone (CFLR015)

Burney Hat Creek Basins 014

Colorado Front Range/CFLR004

Deschutes Collaborative Forest Project

Four Forest Restoration Initiative CFLR005

Grandfather Restoration Project, 019

Lakeview Stewardship Project

Longleaf Pine Ecosystem Restoration \& Hazardous Fuels Reduction/CFLN023

Northeast Washington Forest Vision 2020/Project Number 21

Ozark Highlands Ecosystem Restoration/CFLR022

Shortleaf-Bluestem Community/18

Southwest Jemez Mountains/CFLR006

Southwestern Crown Collaborative (SWCC)/CFLR001

Tapash CFLRP (08)

Uncompahgre Plateau CFLR003

Weiser-Little Salmon Headwaters/CFLN013

Zuni Mountains

Note: Collaborative Forest Landscape Restoration Program.

Source: Collaborative Forest Restoration Program Annual Reports, 2019.

\section{ALL FUNDS}

$\$ 2,236,552$

$\$ 2,806,735$

$\$ 2,355,485$

$\$ 11,128,054$

$\$ 2,608,962$

$\$ 28,490,919$

$\$ 2,253,685$

$\$ 4,706,972$

$\$ 3,362,244$

$\$ 5,377,872$

$\$ 2,826,404$

$\$ 5,155,285$

$\$ 4,406,407$

$\$ 4,361,053$

$\$ 1,070,085$

$\$ 844,121$

$\$ 6,562,808$

$\$ 3,517,008$
DIRECT MILL JOBS

JOBS PER MILLION

13.9

12.1

5.5

0.7

6.5

4.4

4.0

6.4

9.5

7.1

11.0

3.5

2.3

0.7

0.0

3.6

6.6

1.7

9

5.5

.7


GLOSSARY

agroforestry: Agroforestry encompasses practices that combine agriculture and trees to produce benefits such as improved soil health, diversified farm revenue (USFS 2012), improved livestock health (NAC n.d.), improved water quality, and increased carbon sequestration (Montagnini and Nair 2004). Specific agroforestry practices include silvopasture, alley cropping, and windbreaks or riparian buffers.

direct effects: Direct effects represent the initial change in earnings or jobs created by new input activities in the initially changed industries. This is the first round of impacts. An example of a direct effect are the jobs created in the heating, ventilation, and air conditioning (HVAC) industry to make efficiency upgrades targeted by a federal program.

employee compensation: This is the total value of payroll and includes wages or salaries, additional benefits, and payroll taxes. Employee compensation is one of the four components of gross domestic product. The other elements are proprietor income, taxes on production and imports, and other property income.

indirect effects: Indirect effects are those throughout the supply chain resulting from the direct change. This is the second round of impacts. An example of an indirect effect are the jobs created at a high-efficiency boiler manufacturer when an HVAC installation firm purchases its products.

induced effects: Induced effects result from the new earnings created by the direct and indirect effects. These earnings are injected into the economy when workers spend their incomes on any kind of good or service in the region.

private financing: This refers to debt-leveraged funding from financial institutions. The money paid out by financial institutions creates the initial construction impacts.

reforestation: Reforestation describes the process of planting trees or naturally regenerating trees on previously forested land. Reforestation does not include replanting trees after they have been logged for commercial use.

renewable: A source of energy is renewable if it comes from natural sources or processes, like wind and solar, and is constantly replenished.

restocking: Restocking describes the practice of increasing the density of existing forests and/or replanting trees after they have been harvested. Restocking differs from reforestation in that restocking takes place in established forests to restore areas where trees have been lost due to disease, environmental factors, or harvesting.

rural counties: A county is defined as rural according to the U.S. Department of Agriculture 2013 Rural-Urban Continuum Codes. Rural counties fall on the spectrum of scores from 4 to 9 .

taxes on production and imports (TOPI): These include the total value of sales, excise, property, and severance taxes; customs duties; motor vehicle licenses; and special assessments. Subsidies are subtracted. They do not include profit taxes. In some instances, TOPI are negative, implying that the value of subsidies is greater than the taxes generated by the industry. total economic investment: The amount of money infused into the economy after private financing leverage and investments are considered.

tree restoration: Tree restoration describes a set of practices that restores healthy forests and tree cover to historically forested areas. These practices include reforestation and restocking degraded forests and establishing agroforestry systems (see above).

urban communities: A county is defined as urban according to the U.S. Department of Agriculture 2013 Rural-Urban Continuum Codes. Urban counties fall on the spectrum of scores from 1 to 3 .

value added: This represents the difference between total output and the cost of intermediate inputs (consumption of goods and services purchased from other industries or imported). Value added is equivalent to an industry's contribution to gross domestic product.

wildfire risk management: Wildfire risk management involves forest management strategies that mimic the effects of wildfire by thinning overstocked forests and/or using prescribed burns to reduce ground-level fuels. While fuel treatments such as thinning and prescribed burning do diminish carbon stored in forests, they are intended to prevent a far greater release of carbon from high-intensity conflagrations that kill all trees in a stand (Dore et al. 2010).

\section{ABBREVIATIONS}

BLM - Bureau of Land Management

CFLRP - Collaborative Forest Restoration Program

DCI - Distressed Communities Index

DOE - U.S. Department of Energy

DOI - U.S. Department of the Interior

GDP - gross domestic product

$\mathrm{GtCO}_{2} \mathbf{e}$ - gigaton (equal to one billion metric tons) of carbon dioxide equivalent

ITC - investment tax credit

mt - metric ton

$\mathbf{M t C O}_{2}$ - megaton (equal to one million metric tons) of carbon dioxide

OSMRE - Office of Surface Mining Reclamation and Enforcement

PTC - production tax credit

REAP - USDA Rural Energy for America Program

RESP - Rural Energy Savings Program

SEP - State Energy Program

USDA - U.S. Department of Agriculture

USFS - U.S. Forest Service

USFWS - U.S. Fish and Wildlife Service

WAP - Weatherization Assistance Program 
1. Environmental justice communities are those most impacted by environmental risks and harms. They face a disproportionate exposure to environmental hazards.

2. While the full federal investment and corresponding economic benefits for the new climate economy were modeled over a five-year period, the land sector pathways (including tree restoration on federal lands, tree restoration on non-federal lands, and wildfire risk mitigation) offer the opportunity for more extended federal investment and economic benefits. The benefits for these pathways were modeled over a 20-year period. For all pathways, annual job creation and other economic benefits would be expected to extend for as long as federal investments continue.

3. The REAP program offers guaranteed loans and grants to rural businesses and farms for qualifying energy projects, including wind, solar, and biomass generation.

4. Land is deemed suitable for reforestation where significant forest cover occurred prior to European settlement but current canopy cover is less than 25 percent, as described by Cook-Patton et al. (2020). Forest land is deemed suitable for restocking where canopy cover exceeds 25 percent (to avoid double-counting with reforestation opportunities) but current basal area stocking levels are below 60 percent, the minimum level at which the U.S. Forest Service considers forest land to be fully stocked.

5. We estimated the potential for carbon removal from tree restoration using methods consistent with Mulligan et al. (2020). Potential from reforestation was derived from Cook-Patton et al. (2020), while potential from restocking uses area data from the U.S. Forest Service (2021), sequestration rates from Hoover and Heath (2011), and additional potential estimates from Sohngen (2018). Mulligan et al. (2020) estimate the full opportunity for carbon removal to be achievable within 20 years, so we estimated the potential in 2030 to be one-half of the full opportunity.

6. We assessed suitability for reforestation and restocking opportunities and their corresponding carbon removal potential in the same way as for tree restoration on federal lands. We assumed pasture land was suitable for silvopasture wherever it historically supported forest cover (Cook-Patton et al. 2020), with the carbon removal potential estimated using sequestration factors from COMET-Planner (Swan et al. 2015). We determined land suitability and carbon removal potential associated with other agroforestry systems, such as alley cropping and windbreaks, according to the methodology from Fargione et al. (2018).

7. For more information on IMPLAN data sources, see IMPLAN, "IMPLAN Data Sources," last updated 2020, https://implanhelp.zendesk.com/hc/ en-us/articles/115009674448-IMPLAN-Data-Sources.

8. Employment pulled from Emsi, which includes Bureau of Labor Statistics Quarterly Census of Employment and Wages (QCEW) employment and non-QCEW employment derived from County and ZIP Business Patterns, the Railroad Retirement Board, and the American Community Survey.
9. For more information on IMPLAN data for industries and commodities, see Candi Clouse, "546 Industries, Conversions, Bridges \& Construction - 2018 Data," IMPLAN, last updated 2020, https://implanhelp.zendesk. com/hc/en-us/articles/360034896614-546-Sector-Industries-Conversions-Bridges-Construction-2018-Data.

10. For more on IMPLAN data sources, see "IMPLAN Data Sources," IMPLAN, last updated 2020, https://implanhelp.zendesk.com/hc/en-us/articles/115009674448-IMPLAN-Data-Sources.

11. For more on IMPLAN data sources, see "IMPLAN Data Sources," IMPLAN, last updated 2020, https://implanhelp.zendesk.com/hc/en-us/articles/115009674448-IMPLAN-Data-Sources. 


\section{REFERENCES}

Andrews, E., and J. Reiblich. 2020. "Reflections on Rural Resilience: As the Climate Changes, Will Rural Areas Become the Urban Backyard?" William \& Mary Environmental Law and Policy Review 44: 32.

Arnberger, A., M. Ebenberger, I.E. Schneider, S. Cottrell, A.C. Schlueter, E. von Ruschkowski, R.C. Venette, et al. 2018. "Visitor Preferences for Visual Changes in Bark Beetle-Impacted Forest Recreation Settings in the United States and Germany." Environmental Management 61 (2): 209-23. https://doi. org/10.1007/s00267-017-0975-4.

Bair, L., and R. Alig. 2006. Regional Cost Information for Private Timberland Conversion and Management. General Technical Report PNW-GTR-684. Portland, OR: USDA Forest Service, Pacific Northwest Research Station. https:// www.frames.gov/catalog/5515.

BenDor, T., T.W. Lester, A. Livengood, A. Davis, and L. Yonavjak. 2015. "Estimating the Size and Impact of the Ecological Restoration Economy." PLOS ONE 10 (6): e0128339. https://doi.org/10.1371/journal.pone.0128339.

Bhattacharyya, B., R. Richards, and R. Cliffton. 2020. Building a 100 Percent Clean Future Can Drive an Additional \$8 Billion a Year to Rural Communities. Washington, DC: Center for American Progress. https://www,americanprogress.org/issues/green/reports/2020/01/08/479168/building-100-percentclean-future-can-drive-additional-8-billion-year-rural-communities/.

BNEF (Bloomberg NEF), 2021. "2021 Sustainable Energy in America Factbook." New York: BNEF.

Bonnie, R., E.P. Diamond, and E. Rowe. 2020. Understanding Rural Attitudes toward the Environment and Conservation in America. Durham, North Carolina: Duke University, Nicholas Institute for Environmental Policy Solutions.

Booker, C.A. 2019. "Text - S.2452 - 116th Congress (2019-2020): Climate Stewardship Act of 2019." U.S. Senate. https://www.congress.gov/bill/116th-congress/senate-bill/2452/text.

Brown, P.R., and A. Botterud. 2021. "The Value of Inter-regional Coordination and Transmission in Decarbonizing the US Electricity System." Joule 5 (1): 115-34. https://doi.org/10.1016/j.joule.2020.11.013,

Cook-Patton, S.C., T. Gopalakrishna, A. Daigneault, S.M. Leavitt, J. Platt, S.M. Scull, 0. Amarjargal, et al. 2020. "Lower Cost and More Feasible Options to Restore Forest Cover in the Contiguous United States for Climate Mitigation." One Earth 3 (6): 739-52, https://doi.org/10,1016/j.oneear,2020.11.013,

Costa, K., C. Goldfuss, and K. DeGood. 2019. Reducing Carbon PolIution through Infrastructure. Washington, DC: Center for American Progress. https://www.americanprogress.org/issues/green/reports/2019/09/03/473980/reducing-carbon-pollution-infrastructure/.

Dillon, G.K., and J.W. Gilbertson-Day. 2020. "Wildfire Hazard Potential for the United States (270-m), Version 2020." 3rd Edition. Fort Collins, CO: Forest Service Research Data Archive. https://doi.org/10.2737/RDS-2015-0047-3.
D0E (U.S. Department of Energy). 2015. Wind Vision: A New Era for Wind Power in the United States. Washington, DC: DOE. https://www.energy.gov/ sites/prod/files/2015/03/f20/wv_full_report.pdf.

DOE. 2018. "Program Year 2019 Grantee Allocations." Weatherization Program Notice. Effective December 18, 2018. Washington, DC: D0E. http://oeo,sc.gov/ documents/WPN_19-02PY2019GranteeAllocations.pdf.

DOE. 2020. "PY20 State Energy Program Formula Allocations." Washington, DC: DOE. https://www.energy.gov/eere/wipo/downloads/py20-state-energy-program-formula-allocations.

Domke, G.M., S.N. Oswalt, B.F. Walters, and R.S. Morin. 2020. "Tree Planting Has the Potential to Increase Carbon Sequestration Capacity of Forests in the United States." Proceedings of the National Academy of Sciences 117 (40): 24649-51. https://doi.org/10.1073/pnas.2010840117.

Dore, S., T.E. Kolb, M. Montes-Helu, S.E. Eckert, B.W. Sullivan, B.A. Hungate, J.P. Kaye, et al. 2010. "Carbon and Water Fluxes from Ponderosa Pine Forests Disturbed by Wildfire and Thinning." Ecological Applications 20 (3): 663-83. https://doi.org/10.1890/09-0934.1.

E2. 2020. Build Back Better, Faster: How a Federal Stimulus Focusing on Clean Energy Can Create Millions of Jobs and Restart America's Economy. Washington, DC, and San Francisco: E2. https://e2.org/wp-content/uploads/2020/07/E2E4-Build-Back-Better-Faster-Stimulus-Projection-ReportJuly-2020.pdf.

EEI (Edison Electric Institute Business Analytics Group). 2020. "Historical and Projected Transmission Investment (Nominal Dollars)." Updated November. https://www.eei.org/resourcesandmedia/Documents/Historical\%20and\%20 Projected\%20Transmission\%20Investment.pdf.

EIA (U.S. Energy Information Administration). 2020a. "Form EIA-860 Detailed Data." https://www.eia.gov/electricity/data/eia860/.

EIA. 2020b. "Utility Energy Efficiency Spending and Savings Declined in 2018." Today in Energy. https://www.eia.gov/todayinenergy/detail.php?id=42975.

EIA. 2021. "Table 1.1.A. Net Generation from Renewable Sources: Total (All Sectors), 2011-April 2021." Electric Power Monthly, https://www.eia.gov/electricity/monthly/epm_table_grapher.php?t=table_1_01_a.

EPA (U.S. Environmental Protection Agency). 2021. Inventory of U.S. Greenhouse Gas Emissions and Sinks: 1990-2019. Reports and Assessments. Washington, DC: EPA. https://www.epa.gov/ghgemissions/inventory-usgreenhouse-gas-emissions-and-sinks-1990-2019.

Fargione, J.E., S. Bassett, T. Boucher, S.D. Bridgham, R.T. Conant, S.C. CookPatton, P.W. Ellis, et al. 2018. "Natural Climate Solutions for the United States." Science Advances 4 (11), https://doi.org/10.1126/sciadv,aat1869. 
Fargione, J., D.L. Haase, 0.T. Burney, O.A. Kildisheva, G. Edge, S.C. Cook-Patton, T. Chapman, et al. 2021. "Challenges to the Reforestation Pipeline in the United States." Frontiers in Forests and Global Change 4, https://doi. org/10.3389/ffgc.2021.629198.we used GIS analyses, surveys of nursery managers and foresters, and literature synthesis to assess the opportunities and challenges associated with meeting proposed reforestation goals. We considered a scenario where 26 million hectares (64 million acres

Forest2Market. 2019. "New Report Details the Economic Impact of US Forest Products Industry," May 8. h.ttps://www.forest2market.com/blog/new-reportdetails-the-economic-impact-of-us-forest-products-industry.

FSA (Farm Service Agency, U.S. Department of Agriculture). 2020. "Conservation Reserve Program." https://fsa.usda.gov/programs-and-services/conservation-programs/conservation-reserve-program/index.

FSG (Forest Stewards Guild). 2019. Implementation at Cerro del Aire: Preparing the Multi-jurisdictional Landscape for Fire. Final Multiparty Assessment. Santa Fe, NM: Forest Stewards Guild.

Grado, S.C., and A.L. Husak. 2004. "Economic Analyses of a Sustainable Agroforestry System in the Southeastern United States." In Valuing Agroforestry Systems: Methods and Applications, edited by J.R.R. Alavalapati and D.E. Mercer. Volume 2. Advances in Agroforestry. New York: Kluwer Academic. https://link.springer,com/content/pdf/10,1007\%2F1-4020-2413-4.pdf.

Hales, D., W. Hohenstein, M.D. Bidwell, C. Landry, D. McGranahan, J. Molnar, L.W. Morton, et al. 2014. "Chapter 14: Rural Communities." In Climate Change Impacts in the United States: The Third National Climate Assessment, edited by J.M. Melillo, T.T.C. Richmond, and G.W. Yohe. Washington, DC: U.S. Global Change Research Program. https://nca2014.globalchange.gov/report/sectors/rural-communities.

Hoover, C.M., and L.S. Heath. 2011. "Potential Gains in C Storage on Productive Forestlands in the Northeastern United States through Stocking Management." Ecological Applications 21 (4): 1154-61.

IEA (International Energy Agency). 2020. Energy Efficiency 2020. Paris: IEA. https://wwwilea.org/reports/energy-efficiency-2020.

Invenergy. n.d. "Overview: Grain Belt Express." https://grainbeltexpress.com/ overview.html. accessed March 16, 2021.

IOGCC (Interstate Oil and Gas Compact Commission). 2020. Idle and Orphan Oil and Gas Wells: State and Provincial Regulatory Strategies, Supplemental Information. Oklahoma City, OK: IOGCC. https://iogcc.ok.gov/sites/g/files/ gmc836/f/supplemental_information_orphan_wells_5-28-2020.pdf.

JCT (Joint Committee on Taxation), 2020. Estimates of Federal Expenditures for Fiscal Years 2020-2024. Washington, DC: U.S. Congress, https://www.jct. gov/publications/2020/jcx-23-20/.

Junod, A., C. Salerno, and C. Payton Scally. 2020. "Debunking Three Myths about Rural America: How to Improve Research and Reporting for the 2020 Election and Beyond." Urban Wire (blog of the Urban Institute). October 30. https://www.urban.org/urban-wire/debunking-three-myths-about-ruralamerica.
Klobuchar, A. "Text - S.1183 - 116th Congress (2019-2020): Expanding Access to Sustainable Energy Act of 2019." U.S. Senate. https://www.congress.gov/ bill/116th-congress/senate-bill/1183/text.

Koebrich, S., T. Bowen, and A. Sharpe. 2020. 2018 Renewable Energy Data Book. Washington, DC: U.S. Department of Energy, Office of Energy Efficiency \& Renewable Energy.

Kopparam, R. 2020. "Gaps in U.S. Rural and Urban Economic Growth Widened in the Post-Great Recession Economy, with Implications amid the Coronavirus Recession." Equitable Growth (blog). August 6. http://www. equitablegrowth.org/gaps-in-u-s-rural-and-urban-economic-growth-widened-in-the-post-great-recession-economy-with-implications-amid-thecoronavirus-recession/.

Kuipers, J. 2020. Appendix A: Coal Mine Reclamation Employment Estimates for Seven Western U.S. Mine Sites, Billings, MT: Western Organization of Resource Councils, http://www.worc.org/publication/reclamation-jobs-report/.

Lawson, M. 2017. "Federal Lands in the West: Liability or Asset?" Headwaters Economics. February 21. https://headwaterseconomics.org/public-lands/ federal-lands-performance/.

Mai, T., W. Cole, E. Lantz, C. Marcy, and B. Sigrin. 2016. Impacts of Federal Tax Credit Extensions on Renewable Deployment and Power Sector Emissions. Golden, CO: National Renewable Energy Laboratory.

Mayerfeld, D., M. Rickenbach, and A. Rissman. 2016. "Overcoming History: Attitudes of Resource Professionals and Farmers toward Silvopasture in Southwest Wisconsin." Agroforestry Systems 90 (5): 723-36. https:// doi. org/10.1007/s10457-016-9954-7.

McKenzie, D., F.A. Heinsch, and W.E. Heilman. 2011. "Wildland Fire and Climate Change." U.S. Forest Service, Climate Change Resource Center.

Montagnini, F., and P.K.R. Nair. 2004. "Carbon Sequestration: An Underexploited Environmental Benefit of Agroforestry Systems." In New Vistas in Agroforestry: Advances in Agroforestry, edited by P.K.R. Nair, M.R. Rao, and L.E. Buck. Volume 1. Berlin: Springer, Dordrecht. https://doi.org/10.1007/97894-017-2424-1_20.

Morris, A., N. Kaufman, and S. Doshi. 2019. The Risk of Fiscal Collapse in Coal-Reliant Communities. Washington, DC: Brookings.

Mueller, J.T., K. McConnell, P. Berne Burow, K. Pofahl, A.A. Merdjanoff, and J. Farrell. 2021. "Impacts of the COVID-19 Pandemic on Rural America." Proceedings of the National Academy of Sciences 118 (1). https://doi.org/10.1073/ pnas.2019378118.

Mulligan, J., A. Rudee, K. Lebling, K. Levin, J. Anderson, and B. Christensen. 2020. "CarbonShot: Federal Policy Options for Carbon Removal in the United States." Working Paper. Washington, DC: World Resources Institute. https:// www.wri.org/publication/carbonshot-federal-policy-options-for-carbon-removal-in-the-united-states. 
Muro, M., A. Tomer, R. Shivaram, and J.W. Kane. 2019. Advancing Inclusion through Clean Energy Jobs. Washington, DC: Brookings, https://www.brookings,edu/research/advancing-inclusion-through-clean-energy-jobs/.

NAC (National Agroforestry Center, U.S. Department of Agriculture). n.d. "Silvopasture." https://www.fs.usda.gov/nac/practices/. Accessed April 12, 2021.

Nadel, S. 2017. "How Many Billions Do US Businesses and Individuals Invest in Energy Efficiency Each Year?" American Council for an Energy-Efficient Economy (blog). July 18. https://www.aceee.org/blog/2017/07/how-many-billions-do-us-businesses.

Nadel, S., and L. Ungar. 2019. Halfway There: Energy Efficiency Can Cut Energy Use and Greenhouse Gas Emissions in Half by 2050. Report U1907. Washington, DC: American Council for an Energy-Efficient Economy. https: // www.aceee.org/sites/default/files/publications/researchreports/u1907.pdf.

NCE (New Climate Economy). 2018. Unlocking the Inclusive Growth Story of the 21st Century: Accelerating Climate Action in Urgent Times. Washington, DC: Global Commission on the Economy and Climate. https://newclimateeconomy.report/2018/.

Nielsen-Pincus, M., and C. Moseley. 2010. "Economic and Employment Impacts of Forest and Watershed Restoration in Oregon." Working Paper Number 24. Eugene, OR: Institute for a Sustainable Environment, University of Oregon. https://scholarsbank.uoregon.edu/xmlui/bitstream/handle/1794/10776/WP24.pdf?sequence $=1$.

NIFC (National Interagency Fire Center). 2020، "Suppression Costs." https:// www.nifc.gov/fire-information/statistics/suppression-costs.

North, M.P., S.L. Stephens, B.M. Collins, J.K. Agee, G. Aplet, J.F. Franklin, and P.Z. Fulé. 2015. "Reform Forest Fire Management." Science 349 (6254): 1280-81. https://doi.org/10.1126/science.aab2356.

NREL (National Renewable Energy Laboratory). n.d. "JEDI Wind Models. JEDI Offshore Wind Model rel. OSW10.24.17." https://www.nrel.gov/analysis/jedi/ wind.html. Accessed February 2021.

NREL. 2020. "Data Show Big Gains for Offshore Wind," October 8. https:// www.nrel.gov/news/program/2020/2019-offshore-wind-data.html.

Oswalt, S.N., W.B. Smith, P.D. Miles, and S.A. Pugh. 2014. Forest Resources of the United States, 2012: A Technical Document Supporting the Forest Service 2010 Update of the RPA Assessment. W0-GTR-91. Washington, DC: U.S. Department of Agriculture, Forest Service. https://doi.org/10,2737/W0-GTR-91.

Pingree, C. 2021. "A Bill to Address the Impact of Climate Change on Agriculture, and for Other Purposes." Agriculture Resilience Act. 117th Congress, 1st Session. U.S. House of Representatives, https://pingree.house.gov/uploadedfiles/the_agriculture_resilience_act_117th_congress.pdf.

Pollin, R., and S. Chakraborty. 2020. "Job Creation Estimates through Proposed Economic Stimulus Measures." Amherst, MA: Political Economy Research Institute, University of Massachusetts Amherst.
Raimi, D., N. Nerurkar, and J. Bordoff. 2020. Green Stimulus for Oil and Gas Workers: Considering a Major Federal Effort to Plug Orphaned and Abandoned Wells. New York: Columbia Center on Global Energy Policy and Resources for the Future. https://www.energypolicy.columbia.edu/sites/default/files/file-uploads/OrphanWells_CGEP-Report_071620.pdf.

Rosenberger, R.S., L.A. Bell, P.A. Champ, and E.L. Smith. 2012. Nonmarket Economic Values of Forest Insect Pests: An Updated Literature Review. RMRS-GTR-275. Ft. Collins, CO: U.S. Department of Agriculture, Forest Service, Rocky Mountain Research Station. https://doi.org/10,2737/RMRS-GTR-275.

Ross, L., A. Drehobl, and B. Stickles. 2018. The High Cost of Energy in Rural America: Household Energy Burdens and Opportunities for Energy Efficiency. Washington, DC: American Council for an Energy-Efficient Economy. https://www.aceee.org/sites/default/files/publications/researchreports/ u1806.pdf.

Saha, D. 2020. "Grid Modernization: Creating Jobs, Cutting Electric Bills, and Improving Resiliency." Expert Note Series. Washington, DC: World Resources Institute. https://files.wri.org/d8/s3fs-public/expert-note-grid-modernization. pdf.

Saha, D., and J. Jaeger. 2020. "America's New Climate Economy: A Comprehensive Guide to the Economic Benefits of Climate Policy in the United States." Working Paper. Washington, DC: World Resources Institute. https:// www.wri.org/publication/us-new-climate-economy.

Saha, D., and T. Cyrs, 2021. "5 Graphics that Explain Clean Energy Jobs in Rural America." World Resources Institute (blog). April 19. https://www.wri.org/ insights/clean-energy-jobs-rural-communities-us-5-graphics.

Seigner, K., K. Brehm, and M. Dyson. 2021. Seeds of Opportunity: How Rural America Is Reaping Economic Development Benefits from the Growth of Renewables. Boulder, CO: Rocky Mountain Institute. https://rmi.org/insight/ seeds-of-opportunity/.

Schoeneberger, M., G. Bentrup, H. de Gooijer, R. Soolanayakanahally, T. Sauer, J. Brandle, X. Zhou, et al. 2012. "Branching Out: Agroforestry as a Climate Change Mitigation and Adaptation Tool for Agriculture." Journal of Soil and Water Conservation 67 (5): 128A-136A. https://doi.org/10.2489/jswc.67.5128A.

SEIA (Solar Energy Industries Association). 2019، "Solar+Storage." Factsheet. https://www.seia.org/sites/default/files/2019-03/SEIA-Storage-ITC-Factsheet2019March_2.pdf.

Shoemaker, M., A. Gilleo, and J. Ferguson. 2018. Reaching Rural Communities with Energy Efficiency Programs. Washington, DC: American Council for an Energy-Efficient Economy. https://www.aceee.org/sites/default/files/publications/researchreports/u1807.pdf.

Smith, J.E., G.M. Domke, M.C. Nichols, and B.F. Walters. 2019. "Carbon Stocks and Stock Change on Federal Forest Lands of the United States." Ecosphere 10 (3): e02637. https://doi.org/10,1002/ecs2.2637. 
Snider, G., P.J. Daugherty, and D. Wood. 2006. "The Irrationality of Continued Fire Suppression: An Avoided Cost Analysis of Fire Hazard Reduction Treatments versus No Treatment." Journal of Forestry 104 (8): 431-37. https://doi. org/10.1093/jof/104.8.431.

Sohngen, B. 2018. "Summary_data_allsites_20.Xlsx." Ohio State University. Unpublished.

Steel, Z.L., H.D. Safford, and J.H. Viers. 2015. "The Fire Frequency-Severity Relationship and the Legacy of Fire Suppression in California Forests." Ecosphere 6 (1): art8. https://doi.org/10.1890/ES14-00224.1.

Stefek, J., A. Kaelin, S. Tegen, 0. Roberts, and D. Keyser. 2019. Economic Impacts from Wind Energy in Colorado Case Study: Rush Creek Wind Farm. Technical Report. Golden, CO: National Renewable Energy Laboratory. NREL/ TP-5000-73659, https://www.nrel.gov/docs/fy19osti/73659.pdf.

Swan, A., S.A. Williams, K. Brown, A. Chambers, J. Creque, J. Wick, and K. Paustian. 2015. COMET-Planner: Carbon and Greenhouse Gas Evaluation for NRCS Conservation Practice Planning. Washington, DC: U.S. Department of Agriculture, Natural Resources Conservation Service.

UCB (University of California, Berkeley). 2020a. "2035 Report CSV Data." https://www.2035report.com/electricity/.

UCB. 2020b. 2035 Report: Plummeting Solar, Wind, and Battery Costs Can Accelerate Our Clean Electricity Future. Berkeley, CA: UCB. http:// www.2035report.com/wp-content/uploads/2020/06/2035-Report.pdf?hsCtaTracking=8a85e9ea-4ed3-4ec0-b4c6-906934306ddb\%7Cc68c2ac2-1db04d1c-82aT-65ef4daaf6c1.

Ungar, L., J. Barrett, S. Nadel, R.N. Elliott, E. Rightor, J. Amann, P. Huether, et al. 2020. Growing a Greener Economy: Job and Climate Impacts from Energy Efficiency Investments. Washington, DC: American Council for an Energy-Efficient Economy. https://www.aceee.org/sites/default/files/pdfs/efficiency-investments-analysis-sept-2020.pdf.

USDA (U.S. Department of Agriculture). 2017. "Crop Acreage Data." https: // fsa.usda.gov/news-room/efoia/electronic-reading-room/frequently-requested-information/crop-acreage-data/index.html

USFS (U.S. Forest Service). 2012. "What Are Agroforestry's Income Opportunities?" Infosheet. https://www.fs.usda.gov/nac/assets/documents/workingtrees/infosheets/Agroforestrylncome0pps08212012.pdf.

USFS. 2021. "Forest Inventory and Analysis National Program Data and Tools." https://www.fia.fs.fed.us/tools-data/. van Mantgem, P.J., J.C.B. Nesmith, M. Keifer, E.E. Knapp, A. Flint, and L. Flint. 2013. "Climatic Stress Increases Forest Fire Severity across the Western United States." Ecology Letters 16 (9): 1151-56. https://doi.org/10.1111/ele.12151.

Vose, J.M., D.L. Peterson, and T. Patel-Weynand. 2012. Effects of Climatic Variability and Change on Forest Ecosystems: A Comprehensive Science Synthesis for the U.S. Forest Sector. PNW-GTR-870. Portland, OR: U.S. Forest Service. https://www.fs.fed.us/pnw/pubs/pnw_gtr870/pnw_gtr870.pdf.

VS and UCS (Vote Solar and Union of Concerned Scientists). 2017. Vote Solar Memorandum Report. Produced by BW Research. Oakland, CA: Vote Solar; Cambridge, MA: Union of Concerned Scientists.

Wagner, M. 2014. "Restoring Forest Health: We Need to Pick Up the Pace." Dalmas Nelson Lecture, Hinckley Institute of Politics, Salt Lake City, UT. U.S. Forest Service. January 31. https://www.fs.usda.gov/speeches/restoring-forest-health-we-need-pick-pace-0.

WHEJAC (White House Environmental Justice Advisory Council). 2021. "Justice40 Climate and Economic Justice Screening Tool \& Executive Order 12898 Revisions. Interim Final Recommendations." Washington, DC: WHEJAC. https://www.eenews.net/assets/2021/05/17/document_ew_01.pdf.

Wiedinmyer, C., and M.D. Hurteau. 2010. "Prescribed Fire as a Means of Reducing Forest Carbon Emissions in the Western United States." Environmental Science \& Technology 44 (6): 1926-32. https://doi.org/10.1021/es902455e.

WIRES (Working group for Investment in Reliable and Economic electric Systems). 2011. Employment and Economic Benefits of Transmission Infrastructure Investment in the U.S. and Canada. Washington, DC: WIRES. https://brattlefiles.blob.core.windows.net/files/6534_employment_and_economic_benefits_of_transmission_infrastructure_investmt_pfeifenberger_ hou_may_2011_wires.pdf.

WORC (Western Organization of Resource Councils). 2020. Coal Mine Cleanup Works: A Look at the Potential Employment Needs for Mine Reclamation in the West. Billings, MT: WORC.

WRI and GPI (World Resources Institute and Great Plains Institute). 2020. "Industry Policy Options for Inclusion in COVID-19 Economic Recovery Legislation." https://www.betterenergy.org/wp-content/uploads/2020/07/ i3-Economic-Recovery-Recommendations-2.pdf.

Ziliak, J.P. 2019. "Restoring Economic Opportunity for 'The People Left Behind': Employment Strategies for Rural America." Aspen Institute. 


\section{ACKNOWLEDGEMENTS}

We would like to thank those that provided valuable inputs, insights, and feedback for this paper, including Juan-Carlos Altamirano, James Barrett, Tyson Bertone-Riggs, Lori Bird, Christine Cadigan, Aimée Christensen, Susan Cook-Patton, Christina Deconcini, David Dreher, Margaret Farrell, Todd Gartner, Kareem Hammoud, Heidi Huber-Stearns, Joel Jaeger, Claire Jahns, Lesley Jantarasami, Keefe Keeley, James W. Kirby Jr., Zach Knight, Arjun Krishnaswami, Dan Lashof, Ruth McCormick, Kerry Metlen, Ugbaad Kosar, Jillian Neuberger, Luke Plant, Daniel Raimi, Martha Rogers, Andrew Sand, Rebecca Shively, Mary Shoemaker, Clea Schumer, Marek Smith, Rachel Smith, Lowell Ungar, John Watts, and Patrick Whitty.

We also wish to thank BW Research Partnership, especially Philip Jordan and Mitchell Schirch, for conducting the economic impact assessment demonstrating the potential for job creation and other economic benefits in rural America.

Thanks also to Kenan Fikri and Kennedy O'Dell from Economic Innovation Group for providing data and documentation behind their Distressed Communities Index in support of our assessment.

Finally, thanks to Bill Dugan, Emily Matthews, Emilia Suarez, Rosie Ettenheim, Romain Warnault, and Sarah DeLucia for providing production, design, and editing support; Matt Herbert, Molly Bergen. and Carrie Dellesky for providing communications and engagement support; and Matthew Cronin for providing overall project support.

This project was made possible through the generous support of Ruth McCormick Tankersley Charitable Trust.

\section{ABOUT THE AUTHORS}

Devashree Saha is a senior associate at WRI.

Contact: devashree.saha@wri.org

Alex Rudee was a manager in WRI's U.S. Climate Initiative.

Haley Leslie-Bole is a research analyst in the WRI Climate Program.

Contact: haley.leslie-bole@wri.org

Tom Cyrs is a research associate in the WRI Climate Program.

Contact: tom.cyrs@wri.org

(creative $($ c)

Copyright 2021 World Resources Institute. This work is licensed under the Creative Commons Attribution 4.0 International License.

To view a copy of the license, visit http://creativecommons.org/licenses/by/4.0/ 